Faculdade de Ciências e Letras da Universidade Estadual Paulista "Júlio de Mesquita Filho" campus de Araraquara

\title{
Um intelectual na trincheira: José Honório Rodrigues, intérprete do Brasil
}

PAULO ALVES JUNIOR 


\section{Um intelectual na trincheira: José Honório Rodrigues, intérprete do Brasil}

Tese apresentada ao Programa de Pós-Graduação em Sociologia da Faculdade de Ciências e Letras da Universidade Estadual Paulista "Júlio de Mesquita Filho" campus de Araraquara, para obtenção do titulo de Doutor em Sociologia.

Orientador: Prof. Dr. José Antonio Segatto. 
Em memória daqueles que se foram:

Paulo Alves, Joaquim Alves, Palmira dos Santos Alves e Marlene Barbosa Ribeiro.

Todos fundamentais ao longo desses 38 anos... 


\section{Agradecimentos}

O final de um trabalho, que consome aquele que pretende um espaço na vida intelectual de um país como o nosso, sempre conta com a contribuição de muitos que foram determinantes ao longo dessa trajetória. Sendo assim, agradeço ao meu orientador o professor José Antonio Segatto, pela paciência nesses anos, os professores Milton Lahuerta e Antonio Rago Filho pelas sugestões de grande valia durante a qualificação, bem como a Capes pelo auxílio ao longo dessa pesquisa. Aos componentes da banca de doutoramento a professora Vera Lúcia Vieira, Wanderson Fábio de Melo e Ângelo Del Vecchio.

Aos amigos sempre presentes: Cida, Rosinha, Silvana, Sônia, Piva e Basilele, prestativos e dispostos a ajudar em qualquer momento.

Menção especial a minha adorável mãe "D. Dalva" sempre ao meu lado e pronta a tudo para auxiliar "os seus". Meu irmão Fábio e cunhada Sheila sempre solícitos. A querida família Melo, tenho o prazer de conhecê-los a mais de 15 anos e me considerar um membro.

Por fim a razão de chegar a esse momento e concluir - com todos os limites - essa pesquisa; meus filhos Leon e Maria Beatriz e a minha companheira, mulher da minha vida: Fábia... a vocês perdão pelos transtornos e a minha eterna gratidão, pela compreensão e a felicidade diária que é te-los ao meu lado. A vocês o meu eterno amor!

Obrigado a todos! 
Não sei se alguma vez disse ao leitor que as ideias, para mim, são como as nozes, e que até hoje não descobri melhor processo para saber o que está dentro de umas e de outras, - senão quebrá-las.

ASSIS, Machado de. "O mundo das ideias" 


\section{Resumo}

Este trabalho pretende recuperar a trajetória do intelectual carioca José Honório Rodrigues que, ao longo de sua vida, tematizou a respeito da teoria e metodologia da História e, a partir do decênio de 1950, passou a centrar sua obra na produção de uma interpretação da sociedade brasileira.

A ruptura dos anos 50 pauta-se pelo ideário assumido pelo autor, isto é, o nacionalismo-liberal, sendo que este foi a base de suas tematizações e de sua interpretação do Brasil. O núcleo interpretativo oferece uma compreensão do país, tendo a conciliação como base de explicação da sociedade, pois a partir dessa reflexão o autor aponta para os momentos em que a liderança política, assumindo a "conciliação" com o povo, proporciona a melhoria nas condições de vida do povo e, dessa forma, evita a prática de uma "História Cruenta" por parte das lideranças antipovo.

Essa análise de José Honório foi determinante para sua crítica aos rumos da sociedade no contexto posterior ao golpe civil militar de 1964, denominado o período como "Generalismo presidencial". Sua crítica ao "presidencialismo imperial" dos militares o levou a assumir uma postura de reflexão e posicionando de forma ativa na "Política Externa Independente", a partir de 1965.

Sendo assim, nosso intuito é recuperar todo esse contexto que permite a identificação de José Honório Rodrigues como um intérprete da sociedade brasileira.

Palavras chaves: José Honório Rodrigues. Pensamento social brasileiro. Conciliação. Nacionalismo-liberal. 


\begin{abstract}
This paper to recover the trajectory of intellectual Jose Honorio Rodrigues, who, throughout his life, thematized on the theory and methodology of history and from the decade of 1950, has focused his work in producing an interpretation of society Brazil.

Rupture of 50 years is guided by the ideas given by the author, that is, liberal-nationalism, and this was the basis of their analytic themes and their interpretation of Brazil. The core offers an interpretive understanding of the country and the reconciliation as a basis for explanation of society, because from this discussion the author points to times when leadership, taking the "reconciliation" with the people, provides better conditions life of the people and thus avoids the practice of a "grisly history" by the leaders'.

This analysis of Jose Honorio was instrumental in his criticism of the direction of society in the context of post-civil-military coup in 1964, called the period as "general president." His criticism of the "imperial presidentialism" of the military led him to assume a posture of reflection and positioning of the active form in the "Independent Foreign Policy" from 1965.

Thus, our aim is to restore that environment that allows the identification of Jose Honorio Rodrigues as an interpreter of Brazilian society.
\end{abstract}

Key words: Jose Honorio Rodrigues. Brazilian social thought. Comm. Liberal Nationalism. 


\section{SUMÁRIO}

José Honório Rodrigues um intérprete do Brasil: Introdução

I - A trajetória de José Honório Rodrigues: do teórico da História a intérprete do Brasil

1.1 - Um intelectual na trincheira: o nacionalismo revisionista

1.2 - A inovação historiográfica: A Teoria da História do Brasil

1.3 - O pensamento historiográfico conservador: Varnhagen um capítulo da

1.4 - História Viva: a ESG e a adesão ao nacionalismo liberal

II - Conciliação e conciliadores: a História Cruenta na formação da

2.1 - Limites da conciliação: $O$ tradicionalismo da elite dirigente

2.2 - A conciliação de José Bonifácio: projeto de modernização para o Brasil

2.3 - O liberalismo conciliador de Tavares Bastos: O político da integração

2.4 - História Cruenta: a ocultação dos movimentos sociais no Brasil

$2.5-$ Rebeliões Regenciais: História cruentíssima

2.6 - Movimento abolicionista: outro exemplo de História Cruenta

III - José Honório Rodrigues e o contexto do golpe militar e a política

3.1 - O governo militar e a crítica honoriana ao "generalismo presidencial"

3.2 - O nacionalismo e a política externa independente: um compromisso

3.3 - A crítica a Política Externa dos militares

3.4 - A aproximação do Brasil com a China comunista e os países africanos: interesses de uma possível potência

IV - José Honório Rodrigues e o pensamento social brasileiro

4.1 - Formação do pensamento social brasileiro: o nacionalismo liberal de

4.2 - A historiografia nacionalista: José Honório Rodrigues, intérprete de

4.3 - $\quad$ O pensamento ultraconservador de Oliveira Vianna: José Honório $\quad 180$ Rodrigues e a crítica à elite oligárquica

4.4 - Crítica ao pensamento tradicionalista: Francisco Iglésias, um seguidor de José Honório 


\section{José Honório Rodrigues um intérprete do Brasil: Introdução}

A tentativa de tematizar o que seria um intérprete do Brasil é extremamente complexa e propicia, no mais das vezes, um grande fórum de debates e polêmicas ${ }^{1}$. No arcabouço dessa discussão, vários estudiosos já emitiram sua opinião a respeito do tema e, embora nem todos encontrassem respostas satisfatórias, alguns conseguiram, sucintamente, formular teorias que seriam consideradas clássicas. Um bom exemplo é a apresentação de Antonio Candido para Raízes do Brasil, na qual o prefaciador mostra a trajetória dos "clássicos" que integraram a "Geração de 30"2. Ademais, outros são considerados de menor quilate, e só aparecem como referência de segunda mão, recebendo, portanto, pequeno prestígio quando se trata de "pensar o Brasil".

O núcleo deste trabalho visa "dar luz" a um desses intérpretes renegado à condição de "segunda mão". Um intelectual que ficou, ao longo dos anos, restrito aos departamentos de História de algumas poucas e boas universidades: José Honório Rodrigues. Autor de fundamental importância nas áreas da pesquisa, teoria e metodologia das ciências humanas.

Todavia, acreditamos que a sua contribuição não se restrinja somente às lides históricas. Contrariamente a certas linhagens interpretativas que não vinculam o

\footnotetext{
${ }^{1}$ A respeito da definição de "intérprete do Brasil", seguimos o argumento de André Botelho e Milton Lahuerta: "Além dos limites cognitivos na explicação racional e sistemática da sociedade, o que se coloca em jogo, dessa perspectiva, é também que toda interpretação sempre procura conferir algum significado e motivação à própria ação. Mas também nesse aspecto, todavia, torna-se difícil operar com uma noção positivista de isenção ou neutralidade do conhecimento sociológico, não simplesmente tendo em vista os seus portadores sociais, mesmo enquanto especialistas rigorosos, mas, sobretudo, o próprio caráter reflexivo do conhecimento sociológico. Noutras palavras, a ênfase no debate sobre as diferentes concepções mais ou menos voluntaristas acerca do papel social dos cientistas sociais nem sempre favoreceu o próprio reconhecimento da própria particularidade da reação das Ciências Sociais com seu objeto. Particularidade referida ao fato de que as formas de conhecimento sobre o social tem consequências práticas para a sociedade, ou ainda, que as práticas sociais são afetadas pelo constante reexame a que são submetidas a partir das informações produzidas sobre elas." (Botelho e Lahuerta, 2005: 9). Outro aspecto realçado por Botelho: “Acrescentamos que as diferentes interpretações do Brasil também se tornaram, ao longo do tempo, como que matrizes de diferentes modos de sentir e pensar o país e de nele atuar." (Botelho e Schwarcz, 2009: 13).

2 No prefácio da edição comemorativa de 30 anos de Raízes do Brasil, Antonio Candido escreve: "Os homens que estão hoje um pouco para cá um pouco para lados cinqüenta anos aprenderam a refletir e a se interessar pelo Brasil, sobretudo em termos de passado e em função de três livros: Casa-grande e senzala, de Gilberto Freyre, publicado quando estávamos no ginásio; Raízes do Brasil, de Sérgio Buarque de Holanda, publicado quando estávamos no curso complementar; Formação do Brasil contemporâneo, de Caio Prado Junior, publicado quando estávamos na escola superior. São estes os livros que podemos considerar chaves, os que parecem exprimir a mentalidade ligada ao sopro de radicalismo intelectual e análise social que eclodiu depois da Revolução de 30 e não foi, apesar de tudo, abafado pelo Estado Novo. (Candido, 1995: 9).
} 
intelectual carioca a nenhum desses grupos, o cerne deste trabalho apóia-se na tese de que existe, em sua obra, uma linha de interpretação da sociedade brasileira. Esta enseja que, ao longo do processo histórico, sempre existiu uma lógica de "conciliação pelo alto", entre a "elite" e os "setores subalternos", sendo que este último seria "capado e sangrado"3 pelos setores dirigentes. Nesse sentido, a resultante da História do Brasil seria uma "História cruenta", sem possibilidade de atendimento às legítimas aspirações do povo.

Pretendemos, com este estudo, discutir a produção intelectual de Honório no campo da Sociologia, pois acreditamos que o legado que ora recuperamos expressa a acumulação teórica que a prática política e social do país, ao longo dos anos de 1950, produziu em relação ao pensamento social e político brasileiro ${ }^{4}$. Além disso, a proposta frisa apontar para a possibilidade de diálogo entre as áreas de História e Sociologia, inserindo nossa pesquisa na tradição da sociologia histórica.

\section{Segundo Theda Skocpol:}

Estudos sociológicos realmente históricos têm algumas ou todas as características seguintes. De forma fundamental, eles levantam questões sobre estruturas sociais ou processos compreendidos como concretamente situados no tempo e no espaço. Segundo, eles se referem a processos no tempo e seguem seriamente seqüências temporais em busca das consequências. Terceiro, a maioria das análises históricas acompanha a inter-relação de ações significativas e contextos estruturais de forma a permitir a compreensão das consequências inesperadas e também das pretendidas nas vidas individuais e nas transformações sociais. Finalmente, estudos sociológicos históricos evidenciam detalhes particulares variáveis de formas específicas de estruturas sociais e padrões de mudança. As diferenças sociais e culturais, junto com processos temporais e contextos, são intrinsecamente de interesse para sociólogos orientados historicamente. Para eles, o passado do mundo não é visto como uma história de desenvolvimento unificado ou um conjunto de sequiências padronizadas. Ao contrário, compreende-se que grupos ou organizações escolheram ou caíram em ritmos variados no passado. (Skocpol, 2004: 41).

\footnotetext{
${ }^{3}$ A ideia de "povo capado e sangrado" que José Honório Rodrigues sempre faz menção em suas obras é de Capistrano de Abreu que, em correspondência com João Lucio Coutinho em 16/07/1920, afirma que: "o povo foi durante três séculos capado e recapado, sangrado e ressangrado." (Abreu, 1976: 389).

${ }^{4}$ O professor Gildo Marçal Brandão explica que: “... o estudo do pensamento político-social foi capaz de formular ou de discriminar na evolução política e ideológica brasileira a existência de "estilos" determinados, formas de pensar extraordinariamente persistentes no tempo, modos intelectuais de se relacionar com a realidade que subsumem até mesmo os mais lídimos produtos da ciência institucionalizada, estabelecendo problemáticas e continuidades que permitem situar e pôr sob nova luz muita proposta política e muita análise científica atual. Também aqui, como em outras partes do mundo, o esclarecimento das lutas espirituais do passado acaba se revelando um pressuposto necessário à proposição de estratégias políticas para o presente." (Brandão, 2007: 29). Outros trabalhos de importância a respeito são os de Daniel Pecaut (1990) e Luis Fernando da Silva (2003). O primeiro explorando a participação política dos intelectuais no Brasil a partir do decênio de 1920 e o segundo recuperando a trajetória de intelectuais que foram responsáveis pela introdução do "marxismo acadêmico" no Brasil a partir da década de 1950. A respeito do marxismo acadêmico ver: Lahuerta (1999 e 2001).
} 
Acreditamos que esta empreitada seja possível, pois verificamos em sua obra uma contribuição que amplia a leitura de determinados aspectos da sociedade ${ }^{5}$. Nesse sentido, procurando criar explicações para as formas típicas de "se pensar", , bem como um legado meritório, que não se omite na tentativa de procurar conceituações e categorias que nos ofereçam a tão procurada "chave heurística" de entendimento do Brasil, procuramos entender a produção honoriana em sua totalidade com o intuito da melhor compreensão da concepção que essa nos ofereça da sociedade brasileira ${ }^{7}$.

Isso posto, nos parece pertinente indagar que Brasil é esse que Honório busca interpretar? A arguta observação de Luiz Werneck Vianna a esse respeito aponta que:

Pensar o Brasil é muito complicado. Somos o que? Somos o filho do latifúndio com a escravidão, do jacaré com a cobra d'água, um resultado dessa construção. Ainda provocando: somos o príncipe encantado nascido desse cruzamento bizarro, que, tudo pesado, deu certo. Afinal, estamos aqui, cuidando de pensar o Brasil, enquanto ele está se fazendo lá fora. (...) E sempre tivemos a consciência de que esse país tinha uma vocação expansiva, não necessariamente reconhecida no plano dos que o pensam, porque o Brasil pensa com os pés, como nos grandes movimentos migratórios que vararam e ainda varam esse

\footnotetext{
${ }^{5}$ Segundo a professora de Harvard Theda Skocpol: "No meu ponto de vista, a sociologia histórica é melhor compreendida como uma tradição contínua de pesquisa, sempre renovada, devotada para a compreensão da natureza e dos efeitos de estruturas de larga escala e processos fundamentais de mudança. Os desejos de responder a questões historicamente embasadas, e não a paradigmas teóricos clássicos, são a força diretiva. Com certeza, sempre houve e sempre haverá sociólogos que não questionam ou buscam responder questões macroscópicas, historicamente fundamentadas. Ainda que ninguém consiga ignorar contextos estruturais e históricos, nem todos os sociólogos precisam investigar diretamente assuntos como as origens e o desenvolvimento do capitalismo e das nações-Estado; a expansão de ideologias e religiões; as causas e conseqüências das revoluções, e a relação de transformações econômicas e geopolíticas com os destinos de comunidades, grupos e tipos de organizações. Além disso, com certeza houve momentos em que muitos pesquisadores interessados em questões macroscópicas tentaram utilizar modos anti-históricos de lidar com elas. A breve credibilidade do funcionalismo estrutural parsoniano como uma teoria abrangente da sociedade foi um desses momentos." (Skocpol, 2004: 12).

${ }^{6}$ A respeito do assunto Octávio Ianni, afirma que: "Uma das singularidades da história do Brasil é que este é um país que se pensa contínua e periodicamente. Ele se pensa de forma particularmente sistemática, no contexto de conjunturas críticas ou a partir de dilemas e perspectivas que se criam quando ocorrem rupturas históricas. Nessas ocasiões, a sociedade nacional como um todo, ou em alguns dos seus setores sociais mais atingidos pela ruptura, ou mais interessados nela, logo se põem a analisar o curso dos acontecimentos, suas raízes próximas e remotas, suas tendências prováveis no futuro. As interpretações tanto podem priorizar um ou outro setor da sociedade como formular visões de conjunto, integrativas, buscando as linhas mestras da história nacional. Daí a profusão de explicações, interpretações ou teses que se multiplicam, sucedem, complementam e polemizam. Sem esquecer que os intérpretes têm sido principalmente brasileiros; mas que também são estrangeiros." (Ianni, 1995: 41).

Segundo G. Lukács: "Não é o predomínio de motivos econômicos na explicação da história que distingue de maneira decisiva o marxismo da ciência burguesa, mas o ponto de vista da totalidade. A categoria da totalidade, o domínio universal e determinante do todo sobre as partes constituem a essência do método que Marx recebeu de Hegel e transformou de maneira original no fundamento de uma ciência inteiramente nova. (...) A ciência proletária é revolucionária não somente pelo fato de contrapor à sociedade burguesa conteúdos revolucionários, mas, em primeiro lugar, devido à essência revolucionária de seu método. O domínio da categoria da totalidade é o portador do princípio revolucionário da ciência." (Lukács, 2003: 106).
} 
continente, esse contingente imenso de 170 milhões de brasileiros que criou uma realidade fantástica, um país que é uma novidade e uma singularidade! (Werneck Vianna, 2001: 35).

Acreditamos que a busca incansável de compreender essa singularidade nos auxilia no escopo de melhor identificar problemas que são históricos e recorrentes no Brasil, e que levaram à formação de um Estado que não atende às aspirações mais primárias e legítimas do povo. Nesse ínterim, esta pesquisa, centrada na produção intelectual de José Honório Rodrigues, pretende alçar tal intelectual à condição de intérprete do Brasil ${ }^{8}$, destacando a forma como o autor expõe o papel de determinadas forças e grupos sociais na condução do país, além de apontar as mazelas da sociedade. A respeito das "Interpretações do Brasil", o professor André Botelho explica que:

As interpretações do Brasil devem ser tratadas como elementos importantes para a compreensão da articulação das forças sociais que operam no desenho da sociedade, que contribuem para movê-la em determinadas direções. Ou seja, não se pode negligenciar a vigência dessas formas de pensar o Brasil no âmbito da "cultura política", como foi comum ao nosso ambiente acadêmico entre as décadas de 1970 a 1990, porque muitas delas deram vida a projetos, foram assumidas por determinados grupos sociais e se institucionalizaram, informando ainda hoje valores, condutas e práticas sociais. (Botelho, 2007: 15).

Pretendemos explorar a "visão do mundo"9 de José Honório Rodrigues identificando, ao longo de suas obras, as características que denotam a expressão do nacionalismo-liberal. Defendemos que o nacionalismo desenvolvimentista ganha uma melhor definição durante o governo de Juscelino Kubitschek, posto que nesse período gesta-se a proposta de desenvolvimento do capitalismo no Brasil, vinculado à estruturação de um capitalismo industrial e modernizante. Segundo Ricardo Bielschowsky:

Os desenvolvimentistas nacionalistas defendiam, como os demais desenvolvimentistas, a constituição de um capitalismo industrial moderno no

\footnotetext{
${ }^{8}$ A esse respeito ver: Botelho e Lahuerta (2005: 7-15).

${ }^{9}$ Iremos utilizar a conceituação de Lucien Goldmann, segundo esse: "Nem todos os grupos fundados sobre os interesses econômicos comuns, entretanto constituem classes sociais. É preciso ainda que esses interesses estejam orientados para uma transformação global da estrutura social (ou, pelas classes "reacionárias", para a manutenção global da estrutura presente), e que eles se exprimam, assim, no plano ideológico, por uma visão de conjunto do homem atual, de suas qualidades, de seus defeitos e por um ideal do que devem ser as relações do homem com os outros homens e com o universo na humanidade futura. Uma visão do mundo é precisamente esse conjunto de aspirações, de sentimentos e de ideias que reúne os membros de um grupo (mais frequentemente, de uma classe social) e os opõem aos outros grupos (grifo nosso). É sem dúvida, uma esquematização, uma extrapolação, mas a extrapolação de uma tendência real entre os membros de um grupo no qual todos realizam esta consciência de classe de uma maneira mais ou menos consciente e coerente." (Goldmann, 1979: 20).
} 
país. Tinham, como principal traço distintivo, uma decidida inclinação por ampliar a intervenção do Estado na economia, através de políticas de apoio à industrialização, integradas, na medida do possível, num sistema de planejamento abrangente e incluindo investimentos estatais nos setores básicos. Tratava-se de um conjunto de técnicos de órgãos do governo que pautavam seu exercício profissional pela ideologia da industrialização planejada como solução histórica para o atraso da economia e da sociedade brasileiras. Consideravam que a acumulação de capital nos setores estratégicos não podia aguardar a iniciativa e o arbítrio do capital estrangeiro, necessitando de controle e comando interno de agentes de capitalistas nacionais. (Bielschowsky, 2000: 126).

Essa proposta de desenvolvimento de base econômica nacional, em que a industrialização, "integrada num sistema de planejamento abrangente e incluindo investimentos estatais nos setores básicos”, era a idealização da forma de organização estatal que o país deveria apresentar para superar seus problemas e limites históricos. Tal aspecto era discutido por José Honório como as "legítimas aspirações nacionais", segundo o autor de Aspirações Nacionais:

As Nações, como sociedades políticas, vivem sob o império de interesses vitais, que criam reações emocionais e convicções racionais, e dão ao povo e à sua liderança um comportamento histórico unitário. Todas elas têm aspirações permanentes que são fruto do processo histórico, das características do povo e da etapa do processo de desenvolvimento econômico. (...) É no processo histórico que se revelam novas energias espirituais, forças econômicas em expansão, vitalidades políticas que podem manifestar e garantir a perspectiva de expansão das aspirações nacionais (grifo nosso), no campo interno ou internacional, maiores ou menores conforme a capacidade do povo, da liderança e da força econômica. (Rodrigues, 1970: 76).

Dessa forma, identificamos José Honório Rodrigues como um representante do grupo social que compõe o nacionalismo desenvolvimentista da década de 1950, bem como suas perspectivas de entendimento acerca da realidade política e social do Brasil. Em nossa concepção, Honório buscava explicar as contradições da sociedade brasileira, especialmente no tocante a elucidar os rumos em que as lideranças políticas assumiam e que as levavam a instituir práticas que as alijavam do "povo".

Para melhor demarcarmos a utilização da categoria "povo", tal como aparece na produção intelectual de José Honório, seguiremos a proposta do historiador francês Jules Michelet (1798-1874). Segundo o historiador francês:

No momento de começar esta vasta e difícil investigação percebo algo pouco tranqüilizador: estou sozinho nesse caminho e não encontro ninguém que me possa socorrer. Sozinho! Mas nem assim deixarei de avançar, cheio de coragem e de esperança. Nobres escritores, de gênio aristocrático, e que sempre pintaram os costumes das classes altas, lembraram-se do povo e propuseram-se, com boas intenções, a colocar o povo na moda. (grifo nosso). Saíram dos salões e desceram à rua, perguntando aos passantes onde o povo morava. Indicaram-lhes 
as galés, as prisões, os locais mal-infamados. Desse mal entendido resultou algo desagradável: eles produziram um efeito contrário ao que pretendiam. Escolheram, pintaram e narraram, para despertar nosso interesse pelo povo, justamente aquilo que devia nos afastar e assustar. Como? O povo é assim? Gritaram em uníssono os pusilâmines burgueses. Rápido, aumentamos a política, armemo-nos, fechemos as portas, passemos o ferrolho. (Michelet, 1988: 115). (Grifos nosso)

No intuito de conceituarmos a compreensão honoriana de "povo", é válida a observação que utilizamos de Michelet, o qual procura demarcar o cenário em que $O$ povo passa a pertencer de forma indelével à Nação. A preocupação, em destaque no texto do historiador francês, é resultado do processo que está diretamente relacionado aos episódios da Revolução Francesa de 1789. Como resultado do movimento revolucionário francês, aparece o liberalismo representativo da "burguesia termidoriana" (Carvalho, 1998: 25), que foi capaz de destacar a introdução do "povo" como setor social, cuja principal necessidade era receber cuidados por parte da elite que controlava o Estado francês pós-revolucionário.

No cenário representado pelo resgate de Michelet, ou seja, nos anos que antecederam as Revoluções de 1848, o contexto encontrado na França tornava necessária a exposição das condições de vida do povo. Em outras palavras, dar voz ao povo era fundamental para realçar o mais célebre sentimento de 1789, tanto que girondinos e jacobinos foram porta vozes de sua possível condição de consciência de classe $^{10}$. Sendo assim, a particularidade histórica que torna o "povo" merecedor de maior conceituação e preocupação, sobretudo, quanto ao seu papel como agente histórico, ganha seu estatuto originário ao longo do processo societário, culminando com o ápice do processo das Revoluções Burguesas do século XVIII, isto é, A Revolução Francesa de $1789^{11}$.

No Brasil as preocupações para com as condições de vida do povo brasileiro foram outras, raramente visando identificar sua condição de subalterno. $\mathrm{O}$

\footnotetext{
${ }^{10}$ A respeito ver: Lukács (2003) e Iasi (2002).

${ }^{11}$ Sobre o marco histórico da Revolução Francesa como símbolo da supremacia da burguesia, o historiador francês Albert Soboul afirma que: "Ao subverter as estruturas econômicas e sociais, a Revolução Francesa rompia ao mesmo tempo a estrutura estática do Antigo Regime, varrendo os vestígios das antigas autonomias, destruindo os privilégios locais e os particularismos provinciais. Ela tornou possível, do Diretório ao Império, a instauração de um Estado moderno correspondendo aos interesses e às exigências da burguesia. A Revolução Francesa esteve longe de constituir um mito, como se pretendeu, o elemento primordial é que o antigo sistema econômico e social foi destruído e que a Revolução Francesa proclamou, sem nenhuma restrição, a liberdade de empreendimento e de lucro, abrindo assim o caminho para o capitalismo. A história do século XIX demonstra que isso não foi um mito." (Soboul, 1989: 101)
} 
povo brasileiro, como sentenciou, entre outros, Darcy Ribeiro ${ }^{12}$, foi pouco analisado quanto ao seu papel e sua presença ao longo do processo de formação da sociedade, surgindo como categoria de análise somente nas franjas do sistema escravista e, também, como foco das discussões propostas pelo Instituto Superior de Estudos Brasileiro (ISEB) ao longo dos anos $50^{13}$.

Destarte, acreditamos que o pensamento honoriano se assemelha às discussões do ISEB por representar a conjuntura nacionalista existente no Brasil durante o decênio de 1950. Nesse sentido, a interpretação honoriana sobre o processo de conciliação político-social deveria ser a meta primordial das lideranças políticas e manter-se sempre em consonância com o povo.

As forças de resistência à mudança no Brasil são tradicionais e nelas se destacam a resistência jurídica e parlamentar, expressões intelectuais da estrutura econômico-social arcaica. A política de conciliação foi quase sempre uma mistificação e serviu para tapear o curso do processo histórico; seu aspecto positivo consistiu em amortecer os choques da caminhada. Ainda assim alternam-se as lideranças conciliáveis e inconciliáveis e sempre corresponde ao predomínio de uma ou outra o processo sangrento ou incruento. Os conciliáveis ajudaram muito - quando faziam concessões e pensavam no povo - a pacificar a nossa História, contando com o apoio do próprio povo. (Rodrigues, 1965: 48).

A interpretação da sociedade brasileira no que diz respeito a ser "cruenta" ou "incruenta" é resultado das ações políticas que a liderança exerce no controle do Estado. O representante da elite que propõe a "conciliação com o povo", tem como prática a tentativa de introduzir um melhor funcionamento das instituições do país, esse seria a melhor maneira para que o povo tivesse melhores condições de vida. Segundo José Honório Rodrigues:

As nações, como sociedades políticas, vivem sob o império de interesses vitais, que criam reações emocionais e convicções racionais, e dão ao povo e à sua liderança um comportamento histórico unitário. Todas elas têm aspirações permanentes que são fruto do processo histórico, das características do povo e da etapa do desenvolvimento econômico. É no processo histórico que se revelam novas energias espirituais, forças econômicas em expansão, vitalidades

\footnotetext{
${ }^{12}$ Em sua obra O povo brasileiro: A formação e o sentido do Brasil, Darcy Ribeiro argumenta: "O povo não surge no Brasil da evolução de formas anteriores de sociabilidade, em que grupos humanos se estruturam em classes opostas, mas se conjugam para atender às suas necessidades de sobrevivência e progresso. Surge, isto sim, da concentração de uma força de trabalho escrava, recrutada para servir a propósitos mercantis alheios a ela, através de processos tão violentos de ordenação e repressão que constituíram, de fato, um continuado genocídio e um etnocídio implacável." (Ribeiro, 1997: 23)

${ }^{13}$ Em entrevista a Lourenço Dantas Mota, o sociólogo Fernando Henrique Cardoso explica a oposição de sua produção teórica com a produção isebiana. A respeito da categoria "povo”, afirma que: “... o pessoal do ISEB nos parecia pouco rigoroso, não tinha a nossa bagagem acadêmica, que os jovens, como nós na época, valorizavam muito. (...) Para o ISEB, o povo era o sujeito da História, enquanto para nós esse sujeito era indeterminado. Enquanto nós pensávamos em classe, o ISEB pensava em povo." (Cardoso, 1985: 10).
} 
políticas que podem manifestar e garantir a perspectiva de expansão das aspirações nacionais, no campo nacional, maiores ou menores conforme a capacidade do povo, e da liderança e da força econômica (Rodrigues, 1970: 74). (Grifos nossos)

Cabe ressaltar que as tentativas de se amenizar a "história cruenta" sempre esbarram na incompetência da elite dirigente, haja vista que esta não procura melhorar a sua conduta almejando conciliar-se com o "povo". Todavia, existiram momentos em que esses "conciliadores" se destacaram e propuseram projetos que seguiam a prerrogativa das "aspirações legítimas", encontrando, no Estado brasileiro em mutação ${ }^{14}$, o terreno propício tais defesas. Nessa perspectiva, Honório argumenta que:

Aspirações nacionais mais legítimas, comuns a todos, que nenhum brasileiro hesitaria em considerar fundamentais, são, por exemplo, a independência e a soberania, a manutenção da integridade territorial e a defesa da manutenção da unidade nacional, além da defesa intransigente da forma democrática de Regime Representativo, com os poderes divididos e harmônicos. (Rodrigues, 1970: 79).

Acreditamos que a "interpretação honoriana do Brasil" nos fornece cabedal para o entendimento da sociedade no que tange à leitura de um determinado processo societário. Isto é, um processo que freia toda e qualquer dinâmica de desenvolvimento, autonomia e modernização do Estado brasileiro. A sua obra é pertinente no sentido de proporcionar uma interpretação a partir de um viés ideológico nacionalista-liberal que permite vislumbrar aspectos de uma consciência social prática ${ }^{15}$,

\footnotetext{
${ }^{14}$ Parece que aqui encontramos uma luz quanto ao caráter de classe que José Honório Rodrigues expressa em suas argumentações. Francisco de Oliveira, em Crítica a razão dualista explícita o projeto do "Plano de Metas" de Juscelino Kubitschek, ressaltou: "Do lado da definitiva conversão do setor industrial e das suas empresas em unidades-chave do sistema, a implantação dos ramos: automobilístico, construção naval, mecânica pesada, cimento, papel e celulose, ao lado da triplicação da capacidade da siderurgia, orientam a estratégia; por seu lado, o Estado, cumprindo o seu papel, lançar-se-á num vasto programa de construção e melhoramento da infra-estrutura de rodovias, produção de energia elétrica, armazenagem e silos, portos, ao lado de viabilizar o avanço da fronteira agrícola, com obras como Brasília e a rodovia Belém-Brasília." (Oliveira, 2003: 72). Nesse sentido, o Estado passa a ser o fiador do desenvolvimento industrial do país, sua responsabilidade no que diz respeito à exploração da classe operária se evidencia, pois a tão aclamada conciliação com o povo, no bojo de um projeto nacional-desenvolvimentista apresenta uma dinâmica que levou à constituição do capital associado no Brasil, por seu turno, essa relação acaba constituindo os mecanismos de acumulação de capital. Ainda segundo Francisco de Oliveira: "O recorrer do recurso do capital estrangeiro acrescentará novas forças ao processo de acumulação, ao mesmo tempo que coloca, no longo prazo, novos problemas para a continuidade da expansão. Em primeiro lugar, incorporando-se rapidamente uma tecnologia mais avançada, a produtividade dará enormes saltos, ainda mais se essa incorporação se dá em condições das relações de produção que potencialmente já eram, de per si, concentradoras: sobre um mercado de trabalho marcado pelo custo irrisório da força de trabalho, os ganhos da produtividade logrados com a nova tecnologia vão acelerar ainda mais o processo de concentração de renda." (Oliveira, 2003: 76).

${ }^{15}$ Seguimos as determinações de István Mészáros a respeito do assunto: “... a ideologia não é ilusão nem superstição religiosa de indivíduos mal-orientados, mas uma forma específica de consciência social materialmente ancorada e sustentada. Como tal, é insuperável nas sociedades de classe. Sua persistência obstinada se deve ao fato de ela se constituir objetivamente (e reconstituir-se constantemente) como
} 
função que o intelectual ${ }^{16}$ em questão tem como consciência limite ${ }^{17}$ da sua leitura dos projetos de desenvolvimento do capitalismo. A sua obra é pertinente no sentido de proporcionar uma interpretação a partir de um viés ideológico nacionalista-liberal, permitindo vislumbrar aspectos de uma consciência social prática ${ }^{18}$, a função que $o$ referido intelectual $^{19}$, na sua possibilidade de análise instituída pela consciência limite ${ }^{20}$, além da leitura que realiza acerca dos projetos de desenvolvimento do capitalismo.

Acreditamos que o elemento que irá pautar a condição de conciliador ou não com os setores subalternos nada mais é que a forma de desenvolvimento do capital na sociedade brasileira. Assim, se a forma a ser implementada segue na tentativa de manter a associação entre o novo e o velho - via prussiana -, ou o novo incorporando aspectos de modernização da sociedade - via americana ${ }^{21}$. Nesse sentido, acreditamos que o elemento que irá pautar a condição de conciliador ou não com os setores subalternos nada mais é que a forma de desenvolvimento do capital na sociedade brasileira. Assim, se a forma a ser implementada segue na tentativa de manter a

consciência social prática das sociedades de classe, relacionada com a articulação de conjuntos de valores e estratégias rivais que visam o controle do metabolismo social sob todos os seus principais aspectos.” (Mészáros, 1996: 22). A respeito ver: Mészáros (2009).

16 Segundo Gramsci: "Todo grupo social, nascendo do terreno originário de uma função essencial no mundo da produção econômica, cria para si, ao mesmo tempo, organicamente, uma ou mais camadas de intelectuais que lhe dão homogeneidade e consciência da própria função, não apenas no campo econômico, mas também no social e político." (Gramsci, 2000: 15).

$17 \mathrm{Na}$ análise de Lowy e Näir a respeito da conceituação: "Goldmann desenvolve e enriquece esse conceito ao demonstrar que ele constitui o máximo de consciência possível de uma classe, o limite de sua consciência da realidade não pode ultrapassar o horizonte de seu "campo de visibilidade" social." (Lowy e Naïr, 2009: 43). Ainda a respeito do assunto o próprio Goldmann argumenta que: "Os grandes pensadores representativos são aqueles que exprimem, de uma maneira mais ou menos coerente, uma visão do mundo que corresponde ao máximo de consciência possível duma classe." (Goldmann, 1974: 48).

${ }^{18}$ Seguimos as determinações de István Mészáros a respeito do assunto: “... a ideologia não é ilusão nem superstição religiosa de indivíduos mal-orientados, mas uma forma específica de consciência social materialmente ancorada e sustentada. Como tal, é insuperável nas sociedades de classe. Sua persistência obstinada se deve ao fato de ela se constituir objetivamente (e reconstituir-se constantemente) como consciência social prática das sociedades de classe, relacionada com a articulação de conjuntos de valores e estratégias rivais que visam o controle do metabolismo social sob todos os seus principais aspectos." (Mészáros, 1996: 22).

19 Segundo Gramsci: “Todo grupo social, nascendo do terreno originário de uma função essencial no mundo da produção econômica, cria para si, ao mesmo tempo, organicamente, uma ou mais camadas de intelectuais que lhe dão homogeneidade e consciência da própria função, não apenas no campo econômico, mas também no social e político." (Gramsci, 2000: 15).

${ }^{20} \mathrm{Na}$ análise de Lowy e Näir a respeito da conceituação: "Goldmann desenvolve e enriquece esse conceito ao demonstrar que ele constitui o máximo de consciência possível de uma classe, o limite de sua consciência da realidade não pode ultrapassar o horizonte de seu "campo de visibilidade" social." (Lowy e Naïr, 2009: 43). Ainda a respeito do assunto o próprio Goldmann argumenta que: "Os grandes pensadores representativos são aqueles que exprimem, de uma maneira mais ou menos coerente, uma visão do mundo que corresponde ao máximo de consciência possível duma classe.” (Goldmann, 1974: 48).

${ }^{21}$ Com relação as argumentações de "via americana" ou "americanismo", ver: Werneck Vianna, (1976 e 2004). 
associação entre o novo e o velho, terá sua matriz na via prussiana. Se, por outro lado, pautar-se pela incorporação do novo, incorporando aspectos de modernização da sociedade, então será determinada pela via americana.

Trata-se de conceituações para o desenvolvimento de sociedades em que o capitalismo ainda não se cristalizou e o processo de constituição da modernização não seguiu a caminho clássico, como o instituído pelas "Revoluções Burguesas",22. Tal análise, sendo uma prática heurística de uso recorrente entre alguns dos intérpretes da sociedade brasileira ${ }^{23}$, toma como pressuposto as condições que levam ao desenvolvimento da economia mercantil e do capitalismo.

O caso brasileiro aponta para os resquícios de uma sociedade colonial, sendo esse aspecto o elemento específico da conciliação pelo alto. Representamos um caminho de multiplicidade particular, pois no Brasil não existiu uma ordem feudal e a base de sua transformação está calcada em uma estrutura agrária colonial $^{24}$.

Segundo José Honório, os momentos que abriram espaço para uma melhor dinâmica da sociedade brasileira, estavam relacionados a manifestações e projetos reformistas. Tal reformismo, em sua gradual mudança na sociedade, visava contar com "gestores do capital atrófico" 25 que modificariam a forma de controle político do Estado. De acordo com Luiz Werneck Vianna:

Tal Estado está posto, diante de sua sociedade civil, em posição de radical autonomia, embora inexista a intenção de fazer da política um recurso de alavancagem ou de favorecimento da modernização econômica, como atesta a má sorte dos empreendimentos de notáveis homens de negócios, como Mauá, e dos intelectuais de adesão americana, (grifo nosso) que buscaram fazer da empresa econômica um lugar de transformação do mundo. (Werneck Vianna, 2004: 45).

O desenvolvimento da sociedade necessitaria de um projeto que estivesse de acordo com os princípios do liberalismo, ou seja, que a democracia correspondesse ao elo básico entre a Nação e o Estado, consolidando benefícios que deveriam ser "socialmente aplicáveis." 26 Nesse caso, a defesa da conciliação brasileira remete à

\footnotetext{
${ }^{22}$ Em estudo seminal a respeito da via democrática para a sociedade moderna, Barrington Moore Jr afirma que: "Aliando o capitalismo à democracia, após uma séria de revoluções: Revolução Francesa, Revolução Puritana e a Guerra Civil Americana. Com reservas chamarei a via da revolução burguesa, uma via em que a Inglaterra, a França e os Estados Unidos ingressaram, em alturas sucessivas, partindo de sociedades profundamente diferentes." (Moore Jr, 1967: 477).

${ }^{23}$ Ver os trabalhos de Chasin (2000), Coutinho (2000), Fernandes (2006) e Werneck Vianna, (1976).

${ }^{24}$ A respeito do sistema colonial brasileiro, ver: Prado Jr (1980 e 1996).

${ }^{25}$ A respeito da definição de "gestores do capital atrófico" ver: Rago (1998).

${ }^{26}$ Em texto clássico, Existe pensamento político brasileiro, Raymundo Faoro, explicando os limites da ordem liberal no Brasil, explica: "Por meio da representação nacional amplia-se o território democrático,
} 
tentativa de viabilizar uma prática política que se assemelha ao "americanismo", no sentido de vislumbrar que este mantenha seu caráter conciliador pelo alto e vise à modernização do Estado e à instituição do liberalismo de âmbito democrático ${ }^{27}$. Na condução de tal processo, ainda fica mantido o controle pela elite, que define a forma de organização institucional da sociedade, sendo que a liderança fica a cargo de um conciliador que vê com bons olhos a relação com os setores subalternos.

Nessa perspectiva, a particularidade histórica do Brasil afeta diretamente a produção intelectual de José Honório Rodrigues. Acreditamos que o pensador carioca reconheça essa processualidade e que o "americanismo" torne-se a sua referência no sentido de desenvolvimento democrático e liberal da sociedade brasileira. $\mathrm{O}$ "conciliador com o povo", aquele que poderia evitar que este fosse "capado e sangrado", seria o líder representativo de uma ordem institucional que colocasse o Brasil no trilho do "americanismo". Entretanto, o limite para a efetivação de uma sociedade liberal democrática seria a manutenção das relações entre o "velho e o novo". Essa lógica espúria não permite que haja a conciliação - pelo menos no sentido almejado por Honório - que representasse a ordem democrática instituída politicamente, e, assim, a possibilidade de que as aspirações legítimas do povo fossem atendidas.

Essa lógica no pensamento de José Honório Rodrigues se encontra longamente exposta em seus textos que iremos recuperar para análise. Gostaríamos de destacar que a resultante da instituição do "americanismo" seria o elemento determinante para a superação da condição cruenta a qual estaria fadado o povo brasileiro, segundo a visão de Honório:

Não creio que sejamos um povo sangrento, e nos destaquemos pela crueza de nossa história. Mas não creio também que sejamos incruentos como a versão oficial quis nos apresentar. Creio que temos todos os momentos históricos de violência, consentimento de apatia, neste por decisão própria ou por necessidade de sobreviver, e intimidados pela exibição de força dos dominadores, não correu senão o sangue dos líderes, dos mártires, dos que doaram sua vida, crentes num ideal, certo ou errado, de melhoria do Brasil e de seu povo. Os momentos históricos são variados, mas a crueza, o terrorismo e a tortura acompanharam sempre a história do Brasil. (Rodrigues, 1985: 103).

e participativo, conservando, ao superá-lo, o núcleo liberal. Chegar-se-ia a um ponto em que o que fosse democrático pressuporia o espaço dos direitos e garantias liberais, socialmente aplicáveis. A democracia em uma fase mais recente partiria de um patamar democrático, de base liberal, como valor permanente e não meramente instrumental. O quadro seria em outra paisagem, sem que uma reivindicação, por mínima que seja, abale toda a estrutura do poder. O Estado seria outro, não o monstro patrimonial-estamentalautoritário que está vivo na realidade brasileira" (Faoro, 2007: 114).

${ }^{27}$ A discussão a respeito da modernização do Estado brasileiro vem ganhando cada vez mais espaço na produção intelectual do país. Entre aqueles que nos oferecem melhores explicações a respeito do tema. Ver: Bresser Pereira (1996 e 1998), Behring (2003) e Melo (2009). 
Com o golpe militar de 1964, a práxis ${ }^{28}$ de José Honório Rodrigues será permeada pela inserção desse intelectual junto a todas as discussões acerca da política externa brasileira. Esse engajamento segue os pressupostos do nacionalismo-liberal defendido pelo pensador e delineou a discussão no campo das Relações Internacionais. Aspecto que passou a ter uma importância estratégica desde o decênio de 1950, com a adoção de uma política externa de caráter nacionalista no governo Vargas de 19511954, sendo esta radicalizada durante o governo de Jânio Quadros. ${ }^{29}$

A política externa teve um papel decisivo no que diz respeito a introdução do capitalismo de caráter nacional no Brasil, isso ficou mais evidente durante o governo Vargas, pois as discussões para que se adotasse uma política externa atrelada aos interesses do capitalismo nacional ganharam amplitude e espaço de destaque no governo. Segundo Pedro Cezar Dutra da Fonseca:

Vargas instituíra um projeto que visava combinar o saneamento financeiro com as iniciativas desenvolvimentistas, desviando-se da ortodoxia dominante à época em matérias de política econômica. Além disso, destacaram-se os vínculos da burguesia industrial e agrária ao governo, já que beneficiárias de tal projeto e das principais medidas de política econômica; do mesmo modo, identificou-se na "burguesia compradora" o principal foco de oposição a Vargas. Se em tal projeto afigurava-se a iniciativa privada nacional, em termos ideológicos, como sua principal beneficiária, parece incontestável o relevante papel atribuído ao Estado para sua consecução. A este caberia não apenas estabelecer diretrizes e leis favoráveis, nem tão somente levar a efeito políticas econômicas fomentadoras da industrialização e da agricultura, mas investir em áreas essenciais para as quais a iniciativa privada demonstrasse pouco interesse, ou mesmo incapacidade. (Fonseca, 1989: 403).

\footnotetext{
${ }^{28}$ Cabe destacar que entendemos práxis, tal como elaborada por Marx: "A questão se cabe ao pensamento humano uma verdade objetiva não é teórica, mas prática. É na práxis que o homem deve demonstrar a verdade, a saber, a efetividade e o poder, a citoriedade de seu pensamento. A disputa sobre a efetividade ou não-efetividade do pensamento-isolado da práxis - é uma questão puramente escolástica." (Marx, 1978: 51). Outra argumentação que nos parece pertinente a respeito do assunto é a de Karel Kosik: "A práxis na sua essência e universalidade é a revelação do segredo do homem como ser ontocriativo, como ser que cria a realidade (humano-social) e que, portanto, compreende a realidade (a realidade em sua totalidade). A práxis do homem não é atividade prática contraposta à teoria; é determinação da existência humana como elaboração da realidade." (Kosik, 2002: 222).

29 A respeito desse tema, Paulo G. F. Vizentini tece os seguintes comentários: “Ao ensaiar a desobediência face ao alinhamento tradicional, o Brasil buscava atrair a atenção dos Estados Unidos e negociar seu realinhamento em novas bases que permitissem o desenvolvimento. A política externa de Vargas não buscava acabar com a dependência, mas alterar seu perfil de forma mais favorável ao Brasil. Tratava-se da estruturação de uma autêntica política externa para o desenvolvimento. Além disso, o nacionalismo proporcionava bases mais sólidas para um consenso interno e a mobilização política em apoio ao projeto varguista. Mas, às contradições externas do modelo somaram-se as internas. A politização de massas da política exterior foi acompanhada da clivagem "nacionalistas x entreguistas". Esse nacionalismo possível, historicamente limitado e politicamente contraditório, ao penetrar na sociedade e em particular nas massas populares emergentes poderia, entretanto, voltar-se contra os elementos que, em última instância, constituíram seu objetivo básico, o desenvolvimento capitalista." (Vizentini, 1995: 116).
} 
É compactuando com o nacionalismo que de fato era colocado em prática pelo governo em sua iniciativa de levar adiante um "projeto de iniciativa privada nacional", que o intelectual carioca acredita que nesse cenário houve uma “aproximação com o povo" A respeito de Vargas, Honório afirmava que:

A conciliação com o povo vinha da luta pela libertação econômica do país, espoliado pela alienação de pequenos grupos econômicos, ligados a interesses estrangeiros, por isso a grande dificuldade em São Paulo entender sua liderança e seus atos. (Rodrigues, 1965: 95).

A aproximação com o povo foi observada por Honório, além de identificar, na tentativa de manter uma autonomia frente ao "imperialismo e militarismo norte americano", a principal tarefa da Política Externa. A esse respeito, informa que:

Eis ai uma política externa a serviço do Brasil, isto é, do seu Povo e da União e dos princípios gerais da humanidade que são também seus princípios, a defesa da autodeterminação, da não intervenção, do anticolonialismo, do antiimperialismo, do desenvolvimento do comércio internacional e da paz. A defesa do seu interesse nacional o obriga a estar presente em toda parte e não só no Continente e por isso o pan-americanismo, a solidariedade continental ou as emotivas declarações de aliança latina não devem reduzir sua área de ação, que deve ser ampliada sem limitações, sem negligência, para que as decisões dos outros dele não se alheiem. (Rodrigues, 1966: 92).

Destarte, após explicitar o tema e as questões investigativas, encaminhamos a apresentação da estrutura do texto que nos parece ser a mais adequada para a exposição dos resultados desta pesquisa.

No primeiro capítulo, intitulado "A trajetória de José Honório Rodrigues: da teoria da História a intérprete do Brasil”, exporemos o percurso intelectual de José Honório Rodrigues como teórico da pesquisa e metodologia histórica até sua passagem pela Escola Superior de Guerra. É nas fileiras dessa instituição, primeiro como estagiário e, depois, como conferencista, que ocorre uma inflexão na sua produção de modo que esta se direciona rumo a uma "História Viva"30, ou seja, o pensador passa a ter um papel determinante na realização de uma interpretação da sociedade brasileira.

Cabe destacar que, segundo seu argumento, esse resgate esteve, no mais das vezes, pautado pelas questões do presente. Dessa forma, o capítulo aponta essa trajetória no sentido de destacar as suas principais produções no campo teórico das

\footnotetext{
${ }^{30}$ História Viva é o titulo de uma coletânea de textos de José Honório Rodrigues que sai pela Editora Global em 1985. A discussão central dos textos é a respeito da importância da História para o entendimento das questões contemporâneas da sociedade, segundo o autor: "Na historiografia atual revela-se uma forte corrente que visa a analisar conjuntamente acontecimentos manifestos e latentes, discutir ou compreender sistemas organizados e periferias submissas, descrevendo situações aparentes em relação às circunstâncias e fatos ocultos ou disfarçados.” (Rodrigues, 1985: 9).
} 
ciências humanas, o quanto essa se aproxima de seu nacionalismo-liberal. Ainda neste capítulo, pretendemos apontar como a própria ESG, dentro de seus quadros, representa as próprias contradições que o nacionalismo trazia no marco histórico dos anos 50.

No segundo capítulo, "Conciliação: história cruenta e incruenta" pretendemos expor a produção de suas ideias veiculadas através de duas obras fundamentais: Conciliação e reforma no Brasil e Aspirações Nacionais. São textos que trazem um núcleo interpretativo do Brasil, principalmente no que tange às conceituações que procuram explicar o processo político social brasileiro. É intenção desvendar como as formulações de "conciliação" e "história cruenta" expõem sua compreensão acerca do papel do Estado, dos setores dirigentes do Executivo, da burguesia e povo. Entendemos que esse núcleo pauta-se por um ideário nacionalista, que foi consolidado nos anos de ESG.

Em nosso terceiro capítulo, "Generalismo presidencial: o golpe civil militar e a política externa independente", pretendemos elucidar como, a partir de 1964, dentro do cenário resultante do golpe militar, o intelectual carioca passa a tecer críticas ao regime político identificando esse como um "generalismo presidencial", o que acaba criando no Brasil um "imperialismo presidencial". Outro aspecto a ser tratado se remete a levar em conta que a crítica honoriana se debruça sobre a política externa adotada pelos militares. Em tal contexto, Honório passar a defender uma política externa autônoma, condizente ao nacionalismo "realmente existente", e que sofre uma ruptura, a partir da gestão de Vasco Cunha Leitão no Ministério das Relações Exteriores. Nesse contexto, e na defesa da democracia e da autonomia do Estado, o intelectual assume uma posição claramente crítica ao golpe e suas lideranças.

O último capítulo, "José Honório Rodrigues e o pensamento social brasileiro" centra-se no escopo de identificar a interpretação que o intelectual carioca faz de dois intérpretes do Brasil: Capistrano de Abreu e Oliveira Vianna. Destacaremos o modo com que o autor de Conciliação e reforma no Brasil analisa ambos, pois estes apresentam, por meio de suas obras, uma interpretação distinta da realidade brasileira. $\mathrm{O}$ primeiro, na visão de Honório, seria o "maior exemplo de historiador preocupado em dar vez ao povo, tantas vezes capado e recapado, sangrado e ressangrado" (Rodrigues, 1976) e o segundo, seria o maior representante do pensamento conservador, recebendo a alcunha, por parte de Honório, de "ultra-reacionário".

Ao longo desta pesquisa buscaremos ressaltar que o núcleo da leitura interpretativa honoriana pauta-se pelo nacionalismo liberal, sendo que esse aparece 
como "fio condutor" em sua produção intelectual. Além disso, pretendemos expor que o pensamento social e político de José Honório Rodrigues têm espaço cativo entre aqueles que ofereceram contribuições expressivas para elucidar o dilema de "Como pensar o Brasil". 


\section{I - A trajetória de José Honório Rodrigues: do teórico da História a intérprete do Brasil}

Ao longo deste capítulo pretendemos discorrer a respeito do percurso intelectual de José Honório Rodrigues como teórico da pesquisa e metodologia histórica, autor de um conjunto de obras nesse campo que repercutiram positivamente e acabaram sendo elevada a condição de referência nessa área. Essa produção sofre uma mudança a partir de sua passagem pela Escola Superior de Guerra, pois segundo sua afirmação, após a "bofetada de brasilidade", que sofreu nas fileiras dessa instituição, dessa forma, ocorre uma inflexão em sua produção intelectual e esta passa a voltar-se para realização de uma interpretação da sociedade brasileira.

Cabe destacar que, segundo seu argumento, esse resgate esteve, no mais das vezes, pautado pelas questões do presente. Dessa forma, o capítulo aponta essa trajetória no sentido de destacar as suas principais produções no campo teórico das ciências humanas, o quanto essa se aproxima de seu nacionalismo-liberal. Outro aspecto que merece destaque é a respeito da própria Escola Superior de Guerra, ou seja, como que na ESG, existiu todo um conjunto de discussões que representavam as próprias contradições que o nacionalismo trazia no marco histórico dos anos 50.

\section{1 - Um intelectual na trincheira: $O$ nacionalismo revisionista}

O intelectual carioca José Honório Rodrigues (1913-1987), apresentou em um especifico conjunto de suas obras uma produção marcada por estudos, ensaios e documentos históricos de valor para o delineamento do que poderíamos denominar como "questão nacional". ${ }^{31}$ Seus estudos originalmente centravam-se na metodologia e pesquisa histórica, e nesse sentido, acabou produzindo uma obra que passou a ser

\footnotetext{
${ }^{31} \mathrm{O}$ historiador Carlos Guilherme Mota explicitou a preocupação de José Honório Rodrigues quanto as discussões, já nessa obra: "Nessa obra, todos os seus atos, pesquisas e ensaios ligam-se à procura da história nacional, mas não em perspectiva simplista ou conservadora. A chamada questão nacional, a irresolução do Brasil, enquanto país moderno e auto-suficiente, assume, em sua visão de história, importância central." (Mota, 1988: 109).
} 
considerada como marco entre os historiadores brasileiros, A Teoria da História do Brasil $^{32}$.

Seguindo uma tradição inaugurada por Capistrano de Abreu, o pensador carioca propõe uma teoria sobre a história, "revisionista", que leve em consideração o verdadeiro papel do historiador brasileiro, que é entender o seu povo e a participação na construção da história nacional. Segundo Honório:

O revisionismo era é ainda é necessário. A história era muito oficial, defendia sempre os vencedores e vivia submersa no triunfalismo. Instituições oficiais, e semi oficiais, universidades cultivavam uma historiografia capitulacionista. A história vinha sendo confundida com tradição. Esta tem sempre o propósito de controlar indivíduos, sociedade, inspirar classes. É um conceito inteiramente corrompido e usado para fins de manutenção dos privilégios da classe dominante. O futuro da história e dos historiadores é limpar a história das visões decepcionantes de uma tradição da conservação do status quo, mas a da mudança e da luta democrática que o povo brasileiro revelou em várias fases de seu processo histórico. Daí a tese da história cruenta e não cordial. Matar esta tradição responsável pela omissão do povo, pela nostalgia do passado, que se recusa a julgar as possibilidades das classes dominantes ou quer suavizar seus receios - só assim se pode fazer florescer a história, parteira do futuro. (Rodrigues, 1986: 143).

Acreditamos que o resgate da produção honoriana no que diz respeito à teoria e pesquisa histórica expõe a projeção de suas conceituações a respeito dessa área do conhecimento. Sempre pautada por questões que salientavam a necessidade do historiador voltar-se para o presente e para a realidade nacional. E, por fim, a preocupação que passa a ser decisiva em sua produção intelectual, ou seja, o "nacionalismo-liberal", pois, como ele mesmo definira, em sua passagem pela ESG recebera uma "bofetada de brasilidade" (Mello, 1994).

José Honório Rodrigues nasceu na cidade do Rio de Janeiro, No início dos anos 30 entra para a Faculdade de Direito do Rio de Janeiro. Completa sua formação em Direito em 1937, ano que o marca profundamente, pois o golpe do Estado Novo o vaticinou contra as ditaduras, "fossem proletárias ou militares" (Rodrigues, 1978). Assistiu de perto as repercussões do movimento de 1935, o que o apartou da “prática política marxista" (Rodrigues, 1978), e também não criou nenhuma simpatia pelos integralistas. Outro fator determinante no ano de 37 foi a "passagem de seu

\footnotetext{
32 A respeito da relevância da obra de José Honório Rodrigues, o professor Fernando Novais tece os seguintes comentários: "Ligada a diversificação e aos deslocamentos que os estudos de História vem ganhando nos últimos tempos, aparece outra tendência de nossa atual historiografia universitária. Refirome à multiplicação dos estudos da historiografia, isto é, de História da História. Há algum tempo, entre nós, José Honório Rodrigues era praticamente o único a se dedicar a esse gênero sendo, até então, a principal referência a respeito do assunto." (Novais, 2005: 300).
} 
Rubicão" (Mello, 1994: 157), quando saiu vitorioso em concurso literário da Academia Brasileira de Letras (ABL). Naquela mesma época, freqüentando o escritório de Edgardo Castro Rebello ${ }^{33}$, percebeu que não possuía vocação para a advocacia, além disso, nesse mesmo ano completou o livro Civilização holandesa no Brasil, escrito em parceria com Joaquim Ribeiro, nesse mesmo ano a obra foi contemplada com o prêmio de erudição da $\mathrm{ABL}^{34}$.

Com relação à influência do professor Edgardo Castro Rebello ${ }^{35}$, José Honório Rodrigues ressalta:

O professor Castro Rebello, que foi um dos primeiros marxistas teóricos brasileiros e era grande conhecedor da história, estimularam-me a leitura não só de Marx e Engels e outros autores marxistas, mas de autores de várias correntes ideológicas. Mas, na verdade, nunca fui marxista, e isso se revela na minha obra, sobretudo na Teoria da História do Brasil. O marxismo como um método e uma hipótese de trabalho é indispensável, mas não é tudo, e quem a ele adere totalmente fica metido numa camisa-de-força. (Rodrigues, 1986: 143).

O pensador carioca passa os anos de 1943-1944 nos Estados Unidos estudando, graças ao recebimento de bolsa de estudos da Fundação Rockfeller. De volta ao Brasil, José Honório Rodrigues elaborou os Índices anotados das Revistas do Instituto do Ceará (1944-1945), dedicando-se em seguida, a terminar a Bibliografia do Domínio Holandês no Brasil e a Teoria da História do Brasil, que foram publicados em 1949. Em 1952 deu a lume, pelo Instituto Nacional do Livro, A Pesquisa histórica no Brasil, sucessivamente reeditada e ampliada, mas, sem dúvida, foi Teoria da História do Brasil sua obra seminal quanto às contribuições no campo da historiografia.

Sua produção, a partir dos anos 50, passou a andar acompanhada das funções que acumulou no Instituto do Álcool e Açúcar, Biblioteca Nacional, Arquivo

\footnotetext{
${ }^{33}$ Em entrevista concedida a revista Isto É, em 12/abril/1978, José Honório Rodrigues destacou que Edgardo Castro Rebello e Hermes Lima foram os professores que mais os influenciaram na Faculdade de Direito.

${ }^{34}$ Segundo José Octávio de Arruda Mello: "O livro abrange o Nordeste que, para José Honório Rodrigues, significava não apenas o teatro das invasões flamengas, mas o berço do "nacionalismo radical mameluco", assim cunhado por João Ribeiro, que constituiria a base ideológica do honorianismo. Por outro lado, ressalta a doutrina da liberdade dos mares defendida por Grotius em oposição ao mare clausum dos ibéricos; fixa-se no contratualismo de Hugo Grotius e desloca os episódios do Brasil, da primeira metade do século XVII, para o plano internacional, onde o mercantilismo holandês irrompia com força." (Mello, 1994: 158).

${ }^{35}$ A respeito do marxismo de Edgardo Castro Rebello, Leandro Konder expõe que: "Edgardo Castro Rebello (1884-1970) foi jurista de renome, homem de vasta de cultura, advogado de perseguidos. Na realidade Castro Rebello leu Marx a luz das concepções cientificistas que prevaleciam no começo do século XX, porém o que mais prevaleceu em seu pensamento e em suas convicções filosóficas foi e de um campeão do individualismo: o inglês Herbert Spencer." (Konder, 1988: 155).
} 
Nacional e Instituo Nacional do Livro. Toda produção e trajetória intelectual o levou a participar da Escola Superior de Guerra em 1957.

Todo esse resgate da trajetória do pensador carioca visa esboçar sua relevância no que diz respeito à produção no campo historiográfico. Acreditamos que, de um modo geral, ainda não existia uma produção identificada por nós como interpretativa da sociedade brasileira, porém, as teorizações a respeito da história e da pesquisa histórica já demonstravam preocupações no que diz respeito a um revisionismo de caráter nacionalista.

Em 1978, quase trinta anos após o lançamento de Teoria da História do Brasil (1949) vem a público o primeiro volume de História da História do Brasil (1978). Tal demora é explicada pelo autor devido ao vulto que o último livro tomara, tendo levado anos para sua formação definitiva. Em História da História do Brasil (1978), o intuito de José Honório Rodrigues é oferecer uma sistematização a respeito do uso de teorizações para o estudo de História. Nessa obra temos uma tentativa de recuperar aspectos do passado não em sua forma meramente "apologética" (Holanda, 2004: 108), mas que possamos ter interpretações com vigor crítico e científico. A respeito da inovação e relevância da obra honoriana, no que diz respeito à contribuição a teoria da história, Sérgio Buarque de Holanda afirma:

Uma crescente reabilitação dos estudos históricos, feita segundo esse critério, torna-se, pois, exigência imperiosa, a que devem atender as novas gerações. E essa reabilitação pode efetuar-se em grande parte por uma atenção mais dedicada aos problemas da historiografia. Do interesse por esses problemas é característico, entre outros fatos, a publicação recente de um livro como o do senhor José Honório Rodrigues sobre a Teoria da história do Brasil. Sejam quais forem as divergências que possa suscitar essa obra - divergências relativas sobretudo ao método de exposição, que nem sempre deixa transparecer com clareza os pontos de vista do autor -, parece certo que sua simples presença constitui passo importante para o estudo daqueles problemas. Até recentemente ainda dependíamos em grande parte, por esse aspecto, do velho manual de Langlois e Seignobos, publicado ainda no século passado e só há pouco traduzido para o português. (Holanda, 2004: 110).

A necessária discussão a respeito da teorização da história, sua metodologia, a análise documental, bem como a separação do estudo histórico em relação aos estudos literários, todos esses pontos foram preocupações de José Honório Rodrigues ao elaborar sua obra de caráter historiográfico. Os anos que correspondem ao prêmio da ABL até a passagem pela Escola Superior de Guerra (ESG) foram anos de maturação, que, por sua vez, findaram no momento em que sua produção voltou-se às questões que assolavam o país no seu dia-a-dia. 


\section{2 - A inovação historiográfica: A Teoria da História do Brasil}

Neste subitem pretendemos destacar como a obra A Teoria da História do Brasil $^{36}$, além de ser considerado um marco para o estudo e ensino da História no âmbito nacional, representa uma preocupação com o resgate de uma historiografia que procura destacar os interesses mais imediatos e "nacionais" da sociedade brasileira. Ao longo de suas argumentações, José Honório Rodrigues deixa claro que para o avanço da pesquisa histórica é fundamental uma sistematização do seu estudo, é com essa preocupação que propõe uma contribuição de fôlego nesse campo.

A sistematização necessária, enfatizada pelo pensador, é no sentido de criar um método para que os historiadores em formação no Brasil possam produzir uma história que leve em consideração "a variabilidade das opiniões interpretativas e a firmeza do texto, eis os dois pólos fundamentais do trabalho histórico em formação." (Rodrigues, 1978: 428). Ainda segundo Honório:

Uma única exigência se faz, a de que se fique sempre na esfera da existência imediata e do concreto. Só o concreto abre caminho e justifica a teoria. A história quer compreender o mundo espiritual e sócio-econômico, a totalidade da relação subestrutura - estrutura - superestrutura, através da existência, do fato, do documento. Ela quer repensar o que se pensou, ressentir o que se sentiu, refazer o que se fez, rever o criador e o criado, o dirigente e o dirigido, a sociedade, a vida econômica, em suas formas históricas. Ela quer compreender a vida, em todas as suas manifestações. A vida é história, o resto é natureza. Ela é minúscula e fugaz em face desta, mas só nela se criam e se concebem valores, só nela há fins e sentido. Como isto está exausta sua tarefa científica. (Rodrigues, 1978: 429).

Logo na apresentação da primeira edição da obra, o autor destaca que as preocupações versam a respeito da teorização e a metodologia do ensino e da pesquisa histórica no Brasil. A explicação é de grande valia para aqueles anos, vale lembrar que o texto figura como um esforço sistemático de entendimento do diálogo necessário da

\footnotetext{
${ }^{36}$ A respeito de tal obra o historiador mineiro Francisco Iglésias afirma: "Teoria da história do Brasil representava a formulação de matérias fundamentais da historiografia do país. Não era propriamente uma teoria, mas a problemática da história. Via-se a periodização, bem como os diversos gêneros da história, disciplinas auxiliares, crítica, autenticidade e forjicação, atribuição, crítica de textos e edição de documentos, sempre com abundantes exemplos brasileiros e nota sobre o assunto na perspectiva global. $\mathrm{O}$ volume continha ainda capítulos sobre as questões da história e tarefas do historiador, desenvolvimento da ideia de história, filosofia da história, metodologia. Nunca se escrevera aqui nada do gênero. Em edições subsequientes foi revisto e acrescentado. Se vale pelos levantamentos, indicações bibliográficas, a parte propriamente teórica é menos consistente, pois o autor não dispunha de embasamento filosófico ou sociológico para mais rigor em suas considerações. Significou muito, no entanto, não só quando de seu aparecimento, como ainda hoje. (Iglésias, 2009: 180).
} 
História com outras áreas do conhecimento. A respeito José Honório Rodrigues explica que:

$\mathrm{Na}$ história, como em qualquer outra ciência, os progressos referentes ao esclarecimento conceitual, teórico e metódico são tão necessários quanto os relativos ao conhecimento mesmo dos fatos. Se, por outro lado, devemos justamente admitir a pluralidade de métodos científicos, então é necessário conhecer o método próprio, peculiar, especifico da história. $\mathrm{O}$ método aqui exposto aplica-se especialmente a história concreta, mas, de um modo geral, adapta-se a todas as ciências que tem por ideal o conhecimento histórico, ou seja, a economia, o direito, a geografia humana, a sociologia, a antropologia, a literatura, porque todas usam o método histórico, ao contrário das ciências matemáticas, físico-naturais, outro grupo de conhecimentos. (Rodrigues, 1978: 12).

A ideia da obra aparecia pela primeira vez durante o contato com a teoria da história produzida nos Estados Unidos e Europa e a comparação inevitável com o que existia no Brasil a respeito do método e a teoria histórica. Todavia, a sistematização veio com a necessidade docente, haja vista que foi convidado a participar como professor do Instituto Rio Branco. A esse respeito o próprio autor explica:

Já vinha escrevendo esta obra, sempre em contato com o que de mais recente se publicava nos Estados Unidos da América e na Europa quando, convidado pelo Sr. Embaixador Hildebrando Accyoli, então diretor do Instituto Rio Branco, para lecionar o curso de aperfeiçoamento na cadeira de História do Brasil, viu o autor a oportunidade de planejar um curso superior em que, preliminarmente, seriam estudadas a metodologia da historia e sua historiografia. Visava-se dar aos alunos uma ideia mais exata do que é a história de seus métodos e de sua crítica, da bibliografia e historiografia brasileira, de modo a prepará-los para um conhecimento critico da história do Brasil. (Rodrigues, 1978: 11).

As discussões que pautam a elaboração da obra de 1949 - data da primeira edição - ganham amplitude ao longo de suas quatro edições. Sempre com a ampliação das reflexões no que diz respeito principalmente, às condições da pesquisa e da metodologia da história no Brasil e quanto ao papel de representar valores e problemáticas do presente. Esse tipo de preocupação é externado quando argumenta que existe uma íntima conexão entre o passado e o presente, sendo essa relação explicada por Honório da seguinte forma:

É pela conexão entre o passado e o presente que a história possui incessantemente o mundo e age sobre a vida, como a vida age sobre a história. Assim para a história todos são vivos, os que criaram a vida e persistem com sua influência, e os que estão criando vida, gerando o futuro. $\mathrm{O}$ historiador lida com defuntos não para conhecer a morte, o passado, mas para conhecer a vida; é nela que ele pensa; é o mistério da vida que ele persegue. Este é o dinamismo da vida e a oposição entre o instante e o externo, o presente e a história, a unidade do passado e do presente. (Rodrigues, 1978: 27). 
A situação atual de uma sociedade é o ponto principal que o historiador tem por missão compreender. Essa necessidade existe na escala do seu presente e de acordo com o universo de preocupações que pautam a sua formulação. O historiador deve aprender a viver em diferentes mundos, diferentes realidades, complexas como o caso da brasileira. Os significados vitais do passado anunciam seus títulos, o presente coloca-se em posição de fazer valer os seus próprios valores, pois o que vive tem sempre razão em "resgatar" os elementos perturbadores de sua realidade histórica.

A questão fundamental para a organização do "pensamento historiográfico" (Rodrigues, 1978), deve estar em consonância com as preocupações mais vitais e prementes da maioria da população, a História, como ciência que atende “aos vivos e não aos mortos" (Rodrigues, 1978: 29), precisa enfatizar as necessidades do povo. O historiador não, pode se tem o intuito que seu trabalho tenha algum peso do ponto de vista da sua práxis, ausentar-se ou mesmo omitir-se das legítimas aspirações do povo. Destarte, assevera o autor:

Daí a importância da história para a vida e sua significação para o presente. O quadro da história será tanto vivo quanto mais próximo for a problemática que dele derive. A história não deve ser estranha à vida. Ela seria uma obra essencialmente factual, acumulação morta de matérias, despida de espírito, se permanecesse indiferente aos impulsos e estímulos da vida. Nem poderia ser de outro modo. (Rodrigues, 1978: 29).

A historiografia, nesse sentido, configura-se como "espelho onde se refletem os problemas da própria nação e da humanidade" (Rodrigues, 1978), as revisões históricas não nascem das noções históricas concretas, mas da análise e da crítica dos elementos que configuram a forma de atuação e de organização da sociedade. Ao nosso entendimento, a obra de José Honório Rodrigues está voltada a essa discussão, pois não se afasta da questão nacional e, mais ainda, procura compreender como a sociedade civil, em sua organização, pode alcançar maior número de direitos e de instituições democráticas ${ }^{37}$. Deste modo, um problema histórico é sempre uma questão levantada pelo presente em relação ao passado. Consequentemente, o interesse do interrogador, o princípio da seleção, a análise final e o sistema de valores são elementos decisivos na definição da pesquisa. O historiador carioca esclarece que:

Uma determinada compreensão da história nunca é realizada sem suposições apriorísticas, sem hipóteses, sem um quadro geral composto pelos que nos

\footnotetext{
${ }^{37}$ No intuito de identificarmos, qual seria o núcleo da obra de José Honório Rodrigues, estamos de acordo com os argumentos de Skinner (2000), a respeito da validade de determinadas conceituações e temas que ganham maior relevo no conjunto de uma obra.
} 
precederam. O revisionismo histórico, porém não quer atingir fatos, mas as ideias e os valores e, especialmente, as relações entre o presente e o passado que os exigem. Os fatos nus e crus são despidos de significação, e esta só o historiador premiado pelo presente, lhe dá. Mas o acento da significação pode ser colocado de maneira inteiramente diferente. Por tudo isso que a história se ocupa dos vivos e serve à vida é que se impõe, em certos momentos, uma revisão que restabeleça a conexão entre o passado e o presente. (Rodrigues, 1978: 31).

Ocupar-se dos vivos, esse seria o ponto central para manter-se conectado a realidade nacional, aquela deveria ser a proposta de análise para o intelectual que se ocupa com o saber histórico. Nunca se emancipar com a problemática do "mundo em que vive" e procurar apontar em sua produção os nexos entre a sociedade e a história. A historiografia brasileira, expressão de sua história, representava a sociedade "velha e arcaica", com exceção para os textos de Capistrano de Abreu ${ }^{38}$. Por isso a dedicação à história colonial, expressão desse apego às tradições e a cultura luso-brasileiras, “... forma de concepção histórico-filosófica de sua personalidade básica e de seu caráter nacional." (Rodrigues, 1978: 32).

O capítulo que José Honório Rodrigues trata das "tarefas do historiador" foi escrito para a segunda edição da referida obra, que já estava pautada pelas preocupações que o acompanharam, principalmente após a passagem pela ESG, o caráter tradicional da historiografia brasileira é duramente criticado. Ao longo dos textos de Honório, o tradicionalismo seria a expressão de uma produção historiográfica que pretende tratar as questões relacionadas a uma adaptação da intelectualidade aos interesses de uma estrutura social que não se altera, em detrimento de uma força inovadora, que procura a modificação da organização política e social do país.

No Brasil, em que a melhor definição para o historiador carioca seria "arcaico", com uma sociedade relativamente estável e de grande tenacidade nos costumes, o caráter social, isto é, aquele que assegura os padrões de conformidade, a certos elementos da produtividade, da política, do lazer e da cultura, é tradicional; o ritual, a rotina e a etiqueta orientam todos e pouca energia é exigida para descobrir novas soluções para os velhos problemas. (Rodrigues, 1978: 33).

\footnotetext{
${ }^{38}$ Fernando Novais expõe a respeito do assunto: "Quando falamos historiografia brasileira stricto sensu queremos dizer o corpus das obras dos historiadores brasileiros sobre o Brasil, e é neste percurso que Capistrano de Abreu ocupa posição central. Isto porque estamos dando por resolvido outro problema preliminar, que, entretanto é extremamente dificultoso: saber se os cronistas dos tempos coloniais entram, ou não, no corpus de nossa historiografia." (Novais, 2005: 315).
} 
A historiografia brasileira, expressão do Brasil "arcaico e tradicionalista", era predominantemente dedicada à fase colonial ${ }^{39}$. As histórias gerais ou não ultrapassaram a fase colonial ou se excedem desprorpocionalmente nesta em relação à nacional. Desde modo, a história colonial foi, durante ainda os trinta primeiros anos do século XX, a eleita dos historiadores nacionais e dos responsáveis pelas edições de textos históricos.

Isso nos parece evidente porque a escolha pelo período colonial ressalta o destaque ao projeto de dominação da Metrópole, segundo essa interpretação que José Honório Rodrigues define como tradicionalista, porque não leva em consideração qualquer ação dos representantes da população colonial. A meta da produção historiográfica deve ser a análise de processos históricos que procuram repercutir questões de significado nacional. José Honório Rodrigues argumenta que:

Quando, porém, o interesse pelo período nacional sobrepuja o interesse pelo passado colonial, não há dúvida que já conseguimos penetrar numa fase nova da nossa historiografia. Sem rejeitar a herança colonial e procurando assimilá-la numa contradição dialética, e numa catarse analítica, iniciamos os impulsos do Brasil novo, a nova historiografia. (Rodrigues, 1978: 36).

O primeiro momento interpretativo da teoria da história do Brasil que procura romper com esse tradicionalismo e dar ênfase às "questões de significado nacional", foi Capistrano de $\mathrm{Abreu}^{40}$. Com o predomínio dos estudos a respeito da colônia, aos poucos a historiografia do Brasil começa a se manifestar, especialmente na história econômica e social. Basta acentuar que a partir do começo do século “... a história social ocupa, nas venerandas páginas da Revista do Instituto Histórico Geográfico Brasileiro, 44\% da matéria publicada e a partir da década de 1920 ocupa 55\%." (Rodrigues, 1978: 35).

Com Capistrano de Abreu é que teremos uma produção historiográfica nova, expressão de uma sociedade que procura sua constituição como nação emancipada politicamente. O que o historiador carioca vai destacar são os temas

\footnotetext{
${ }^{39}$ Para exemplificar esse aspecto "arcaico e tradicionalista" que recupera o período colonial José Honório Rodrigues destaca a forma de "mazombismo" que caracteriza o desapreço pelo Brasil e ao amor à Europa, que: "nos conduzia à auto-exaltação ufanista, ou ainda a certa flagelação crítica, como o caso de Vianna Moog (1954)." (Rodrigues, 1978)

${ }^{40}$ É necessário destacar que Capistrano de Abreu representa um movimento expressivo de certa intelectualidade brasileira que, pautada pelo positivismo, foi responsável por introduzir todo um conjunto de interpretações e de leituras da realidade brasileira com uma proposta diferenciada do que até então era comum entre nós. Como, por exemplo, a formação da Nação brasileira. Para maiores detalhes: (Alonso, 2002). No $4^{\circ}$ capítulo trataremos da interpretação de José Honório Rodrigues sobre a obra de Capistrano de Abreu, por ora vamos destacar o aspecto inovador da obra do historiador cearense.
} 
selecionados, pois rejeita as origens e as relações européias. Assim, José Honório Rodrigues ressalta:

Seu tema é inteiramente nacional, pois convidava os historiadores brasileiros a não centralizar o seu interesse nas comunidades do litoral, mas no interior, no próprio Brasil arcaico, é verdade, mas nas origens autônomas do Brasil novo: as minas, as bandeiras, os caminhos. A rejeição colonial está implícita no próprio tema colonial. Além disso, desde 1875, Capistrano considerava a Independência como a transformação da emoção de inferioridade a Portugal em consciência de nossa superioridade, embora sem modificar a emoção da inferioridade à Europa. Mas é sua orientação para a historiografia nova que nos interessa agora. (Rodrigues, 1978: 35).

Para o intelectual carioca, foi com o autor de Capítulos de História Colonial (1976), que novos conceitos apareceram para ampliar e compreender a concepção da sociedade brasileira, conceituando problemas que até então não eram contemplados pela historiografia. Um bom exemplo dessa inovação é o destaque que mereceu, por sua parte, a história do regime de terras, a história da legislação e do parlamento, a dos partidos, um dicionário e um atlas de história do Brasil.

Cabe destacar que, devido principalmente às rápidas transformações da sociedade brasileira na transição do XIX para o XX, a historiografia passa a estudar não mais o passado colonial, e sim começa, de forma destacada, a aproximar-se do presente, da fase nacional. Nesse contexto existia uma necessidade de superar o colonial pelo nacional, pois todo um conjunto de novas problemáticas se impunha naquele contexto de fim do período monárquico e início do republicano. Não é demais ressaltar que vivíamos um contexto de nova Constituição (1891) que, ao seu turno, propunha uma nova organização da sociedade civil e a criação de novas instituições que respaldariam a sociedade liberal que se formava. Todavia, a aproximação de José Honório Rodrigues ao intelectual cearense Capistrano de Abreu remonta todo um cenário de mudança e inovação na sociedade que, ao nosso entendimento, foi exposta na produção historiográfica de ambos, pois seriam fundamentais novos elementos interpretativos para elucidar a sociedade ${ }^{41}$. A análise deveria ser pautada por um referencial

\footnotetext{
${ }^{41}$ Em trabalho sobre a obra de Capistrano de Abreu, Denise Guimarães Bottmann, resgata na obra do autor cearense; "a complexa formação dos tipos humanos no Brasil" e explica que: "Com efeito, se tivermos de falar em categorias explicativas em Capistrano, possivelmente elas não concordarão com categorias explicativas formuladas e aplicadas por historiadores contemporâneos. Em primeiro lugar, as suas categorias não se fixam no plano das relações políticas e econômicas juridicamente regulamentadas. No plano das instituições, pouquíssimas apresentam formulação jurídica que contemporaneamente atribuímos a elas. A própria legalidade e formalização jurídica são já, para Capistrano, formas institucionais de segundo grau. As instituições correspondem antes a relações de cooperação, associações, tipo de divisão do trabalho, língua, religiões, forma de partilha temporal e espiritual do poder, sistemas militares de defesa etc. $\mathrm{O}$ fato de serem mesmo pré-sociais ou exclusivamente privadas, não diminui seu
} 
nacionalista, a problemática da questão nacional, sendo assim, seria necessário pensar o Brasil e suas reais possibilidades de crescimento e emancipação, não só política, mas também econômica, além da procura de maior participação do povo na história.

Esse nacionalismo liberal de José Honório Rodrigues se identifica com Capistrano de $\mathrm{Abreu}^{42}$, que vê tantas vezes o povo brasileiro "capado e sangrado". A recuperação da obra do historiador cearense é parte da preocupação honoriana no sentido de produzir uma interpretação da sociedade brasileira a partir de uma perspectiva que destaque a fase nacional em detrimento do passado colonial. Agora já não se trata só de compreender o presente pelo passado, mas também "compreender o passado pelo presente" (Rodrigues, 1978). Estamos na esfera de um pensamento que procura articular uma interpretação da sociedade brasileira, levando-se em conta a necessidade "nacional e atual" pela qual passa o país.

Segundo José Honório Rodrigues:

Para compreender as características fundamentais de certos problemas históricos, é necessário observar e analisar a paisagem atual, porque só ela dá as perspectivas de conjunto, das quais deveríamos partir para o nosso estudo. As ligações profundas do passado e do presente exigem a eterna busca e compreensão da mudança, pois a história é a ciência da mudança. Evidentemente, historiografia viva não é só aquela que trata de temas atuais. Isso seria uma incompreensão, igual a que o historiador deve não só formular suas questões como suas respostas de acordo com os conceitos vivos do presente. As perguntas são feitas muitas vezes de acordo com o presente, como já dissemos, mas as respostas dependem da pesquisa, pois de outro modo o historiador se tornaria tendencioso e sem categoria científica. (Rodrigues, 1978: $38)$.

A preocupação em superar o passado colonial, em detrimento da condição nacional atual, expõe a forma de identificação do pensador carioca com a

peso determinante na formação do caráter-nacional. A análise que constantemente recorremos, elas compõem o material empírico para a formação de tipos humanos específicos. É esta formação complexa, a partir de elementos simples, que me parece ser a efetiva categoria explicativa de Capistrano de Abreu: é ela a mestiçagem.” (Bottmann, 1985: 32).

42 A respeito da relevância de Capistrano de Abreu na produção historiográfica brasileira, Fernando Novais afirma que: "Da mesma forma que os Capítulos da história colonial” tem um posição central em sua obra, Capistrano tem uma posição central na História da história do Brasil. Estamos nos referindo, evidentemente, à "historiografia brasileira" no seu sentido mais estrito. De fato, nem sempre os estudos de História da nossa história tem levado em conta certos pressupostos indispensáveis à demarcação do corpus. (...) Quando falamos "historiografia brasileira" stricto sensu queremos dizer o corpus das obras de historiadores brasileiros sobre o Brasil, e é neste percurso que Capistrano ocupa posição central. Isto porque estamos dando por resolvido outro problema preliminar, que, entretanto é extremamente dificultoso: saber se os cronistas dos tempos coloniais entram, ou não, no corpus da historiografia brasileira. O Brasil como tal não existia então, e nesse sentido os cronistas devem ficar fora; mas o Brasil estava se constituindo, e nesse sentido seus cronistas antigos são a expressão dessa formação." (Novais, 2005: 315). O próprio José Honório Rodrigues posicionou-se nesse debate com relação ao papel dos cronistas na constituição da historiografia brasileira. 
força da sociedade em suas problemáticas contemporâneas. Seja no começo da trajetória republicana do Brasil, seja na transição do decênio de 1950 para 1960, a questão nacional, deveria ser o princípio determinante e norteador para a produção intelectual, independente da área de atuação do intelectual em questão. Nesse sentido, A Teoria da História do Brasil, ao nosso entendimento, já traz fragmentos do nacionalismo radical, preocupado com a melhor forma de organização da sociedade brasileira, pensado a partir da liderança conciliadora com o povo e, através dessa conciliação, seja instituído um governo democrático. Esse contexto é tratado por José Honório ao afirmar que o historiador não "pode desrespeitar o surgimento de novas formas de pensamento que se oferecem aos historiadores nacionais", (Rodrigues, 1978: 49). Sendo assim, o presente torna-se a base para a forma de interpelar o passado.

A obra honoriana não está desvencilhada de toda problemática que deve enfrentar ao levar adiante um projeto de sistematização em determinada área do conhecimento, ou seja, pensar como devemos interpretar os "fatos históricos". Para um expoente do nacionalismo liberal não existe outra forma de trato, se não, explicitar suas referências e preocupações, sendo essas matizadas pelas condições da sociedade, visando sempre atender os interesses da maioria do povo.

\section{3 - O pensamento historiográfico conservador: Varnhagen um capítulo da} História da História do Brasil

Outra obra do período de produção historiográfica que nos parece de suma importância para as discussões aqui propostas é História da História do Brasil.

A História da História do Brasil é resultado de um amplo projeto de estudo e pesquisa a respeito do tema. O livro deveria inicialmente compor-se de três grandes volumes sobre a história do escrito histórico no Brasil. "O primeiro voltado para a crônica colonial dos séculos XVI, XVII e XVIII; o segundo e o terceiro dedicado às concepções históricas que constroem a imagem de uma História do Brasil quase que inteiramente conservadora." (Rodrigues, 1988: 151). Logo no prefácio da obra, o historiador aponta os limites existentes no estudo da historiografia:

A história da história nunca teve tratamento independente no mundo da língua portuguesa. Era na história da literatura, único ramo de historiografia intelectual exercido no Brasil e em Portugal, que se buscava, e se encontrava a análise e crítica da evolução do pensamento e da forma do escrito de histórico. Naturalmente não era nem podia ser satisfatória, porque nela só entravam alguns cronistas e historiadores, examinados segundo critérios literários, 
estilísticos e estéticos. Quase sempre os poucos selecionados eram os melhores exemplares da historiografia, mas a crítica que se lhes fazia não bastava aos estudiosos de história, que nela buscavam mais informações históricas que literárias. Além disso, faltavam muitos que haviam trazido não pequena contribuição ao escrito e estudo histórico. Outros, que haviam realizado obra literária e histórica, eram analisados pelo mesmo critério, sem um conhecimento histórico mais exato. Daí resultava análises como, por exemplo, a de Silvio Romero sobre Pereira da Silva, aplaudido como historiador, sem a necessária reserva aos seus erros e enganos de compilador, e censurado na sua obra literária, quando Joaquim Nabuco e Capistrano de Abreu o criticaram, rigorosamente, do ponto de vista histórico. (Rodrigues, 1988: XV).

O livro pretendia examinar as discussões historiográficas pelo seu valor intrínseco, como contribuição ao desenvolvimento de sua disciplina, especificamente o caso da historiografia. O projeto integral da obra não pode ser concluído devido aos problemas de saúde que acometem José Honório Rodrigues a partir de $1986^{43}$. Com sua doença não foi possível concluir a revisão dos dois últimos volumes: o primeiro, concentrado nos cronistas coloniais; Historiografia Colonial; o segundo, voltado aos historiadores do Brasil pós-independência, a Historiografia Conservadora e a Metafísica do Latifúndio: o Ultra-reacionário Oliveira Vianna, sendo esse volume dividido em dois tomos. Os volumes publicados mantêm a intenção de estudar a crônica colonial e a história nacional como obras históricas. Neles se expressa a preocupação com o estudo de documentos historiográficos que apresentam a evolução do método histórico.

Em A Historiografia colonial, trata da crônica dos séculos XVI a XVIII como documentos historiográfico: fonte para descoberta de fatos e formas rudimentares da história. No volume sobre a historiografia dos séculos XIX e XX, o historiador carioca apresenta as posturas ideológicas daqueles que escreveram história do Brasil. Em ambos os volumes, seus estudos prezam a análise e a crítica do pensamento e da forma do escrito histórico em sua contribuição ao conhecimento social cientifico desenvolvido no Brasil. Aspecto que, para o autor, reverencia o pensamento histórico conservador.

Para executar a "libertação da literatura", José Honório analisa apenas documentos historiográficos, ou seja, somente podem ser levados em consideração aqueles escritos que tinham como finalidade relatar os fatos do passado ou estavam

\footnotetext{
${ }^{43}$ Em 1986, José Honório Rodrigues sofre um acidente vascular cerebral que o impossibilita de escrever e pouco mais de um ano depois acaba levando-o a morte, mais precisamente em abril de 1987.
} 
preocupados em traduzir o seu presente, mesmo que a tarefa para tal apuro seja relativamente complexa. Segundo o autor de A Teoria da História do Brasil:

A distinção não é fácil de se fazer, pois todo documento historiográfico é histórico, mas nem todo documento histórico é historiográfico. Desde que se considere a historiografia como a história da história, só aqueles escritos acabados na forma da descrição ou da interpretação podem ser considerados historiográficos, relatem ou não fatos do passado, ou se limitem ao seu presente. Mas esta distinção tão simples não pode ser facilmente aplicada quando nos defrontamos com uma historiografia tão rudimentar e pobre, salvo poucas exceções. (Rodrigues, 1988: XVII).

Essa forma "rudimentar e pobre" foi elemento de estudo de parte da teoria literária e, em grande medida, vinculada à história da literatura brasileira. Alfredo Bosi, em História concisa da literatura brasileira argumenta a respeito da dificuldade em distinguir a crônica da história, principalmente quando se lida com textos que tratam do período colonial. Segundo o Bosi:

Entretanto, se é um fato que as páginas de Gândavo e de Gabriel Soares de Souza sabem antes a relatório que a reflexão sobre os acontecimentos, já na História do Brasil de Frei Vicente Salvador reponta o cuidado de inserir a experiência do colono em um projeto histórico luso-brasileiro. O que explica as críticas de Frei Vicente à relutância do português em deixar o litoral seguro (onde vive "como caranguejo") e o consequente desleixo em face da riqueza potencial da terra. A sua narrativa detém-se nos sucessos da invasão holandesa na Bahia de que foi testemunha. (Bosi, 1994: 25).

Parece-nos evidente a necessidade de distinguir esse dois campos que não se complementam, a partir do interesse meticuloso do intelectual, pois ambos guardam uma estrita conexão com a realidade e são sempre narrativas, contudo, a crônica tem caráter descritivo e a história caráter interpretativo. Para José Honório Rodrigues, a crônica narra os acontecimentos "in status nascendi” (Rodrigues, 1979), sendo fonte de apreensão da realidade viva dos sucessos e episódios diários. Seu relato do real implica certa parcialidade, e não a generalização que formula a interpretação dos fatos, ou seja, a teoria dos acontecimentos.

A história é narrativa “post mortem” (Rodrigues, 1988) dos acontecimentos, generaliza os motivos da ação a partir da particularidade dos sucessos. Sempre expressa a "visão de mundo", ainda que algumas narrativas apresentem teoria dos fatos de maneira "tacanha ou preconceituosa" (Rodrigues, 1988). Na crônica encontra-se uma forma primária e clássica da história, pois a narrativa da atualidade é a primeira forma de escrito histórico. Sendo assim, a crônica colonial pode revelar os traços originais da história nacional, seja quanto ao método, seja quanto à narrativa. 
Pelo estudo da historiografia (crônica e história), confirma-se que alguns traços são singulares, enquanto a "imagem da história do Brasil" que os autores construíram em várias narrativas $^{44}$, obedecendo a posturas políticas e não a estilos literários descritivos.

Passemos agora ao momento em que o intelectual carioca discorre sobre as relações existentes entre os expoentes do pensamento conservador e a elaboração de uma determinada interpretação da sociedade. A tradição historiográfica é conservadora, na verdade o domínio das minorias foi sempre tão expressivo que as classes médias e trabalhadoras - escravos primeiro e livres depois -, revelaram sempre uma deferência, um respeito, um acatamento para com os seus superiores, que não só reprimiram as lutas de classes, como mantiveram no "seu devido lugar as classes sociais majoritárias." (Rodrigues, 1988a: XXXV).

Essa postura autoritária e repressora descrita por José Honório Rodrigues mostra o posicionamento adotado pela elite, "seja agrária ou militar" (Rodrigues, 1988a: XXXV), tal ação visa à defesa inconteste do conservadorismo.

O conservadorismo sempre defendeu a tese de que a história seria favorável às fases em que o poder foi exercido por estadistas sectários do princípio da autoridade e não pelos partidários do liberalismo, mais ardente e generoso que refletido. O pensamento conservador está sempre associado ao medo da mudança ou à resistência a ela, o que caracterizou a política brasileira do Império e maculou a atividade liberal brasileira, também dominada pelo temor das grandes mudanças, como era o caso ao longo do período monárquico e, de forma mais destacada, durante a abolição da escravidão. (Rodrigues, 1988a: $5)$.

A historiografia conservadora propunha enaltecer a tese de que a história favorecia as fases em que o poder fora exercido pelos sectários, e não pelos partidários do liberalismo mais democrático. Uma característica desse conservadorismo é a sua resistência as exigências populares, exaltando sempre as forças conservadoras sobre as revolucionárias e defendendo "barreiras criadas contra o radicalismo." (Rodrigues, 1979: 6).

Entre aqueles que escreveram a respeito do processo histórico brasileiro e são responsáveis pelas primeiras interpretações da sociedade, José Honório destaca, como representante desse pensamento conservador, Francisco Adolfo Varnhagen,

\footnotetext{
${ }^{44}$ Num ensaio que diferencia Narrar ou Descrever, o intelectual húngaro Lukacs explícita os avanços possíveis numa composição textual para o autor que procura a forma narrativa como critério de exposição, "A narração distingue e ordena. A descrição nivela todas as coisas." (Lukacs, 1965: 62).
} 
fundador de uma corrente historiográfica que representa o "espírito do pensamento burguês brasileiro."45

Para tanto, o que foi fundamental nessa linha de argumentação é o passo determinante que, seja do ponto de vista ideológico, seja pelo mérito da recuperação de documentos históricos pouco utilizados até então, Varnhagen vincula o processo que culminou com a emancipação política do Brasil, aos feitos e realizações da família real portuguesa. Para José Honório Rodrigues:

Varnhagen foi o primeiro historiador brasileiro a aplicar os princípios conservadores à construção de sua história do Brasil. $\mathrm{O}$ grande tema de seu livro é a obra da colonização portuguesa no Brasil. Embora monarquista convicto, o que caracteriza sua obra não é o monarquismo, mas o colonialismo que defende o conservadorismo que marca sua interpretação. Era devoto de D. Pedro II, a quem deve sua carreira, mas seu livro é sobre a história colonial, não lhe dando oportunidade de revelar seu monarquismo e bragantismo. (Rodrigues, 1988a: 14).

Os acontecimentos políticos que pontuam o destrinchar do século XIX para a colônia portuguesa na América foi plasmado pela chegada da corte no Rio de Janeiro em 1808. Para a História do país, essa presença foi decisiva, pois permitiu que a "Casa de Bragança", além de solucionar seus problemas imediatos com Napoleão Bonaparte, também instituísse uma nova condição à colônia, pois essa passava a ser sede da monarquia portuguesa. Dessa forma, tal monarquia entra no século XIX, isto é, instalada na capital de sua colônia, sendo responsável por um processo de "grande paradoxo", pois:

É um paradoxo digno de ser notado que nossa história política se abra - num mundo conturbado por ideais e realizações revolucionárias - exatamente por uma força e um poder político que encarnavam o passado em vias de destruição e banimento. Superada pelo tempo, desgastada pelas próprias condições em que se deu o translado da família real, a corte portuguesa chega ao Rio de Janeiro trazendo visíveis sinais de fragilidade. Contudo, esta fragilidade ostensiva da monarquia portuguesa é um dos aspectos que se devem reter, quando se pretende compreender todo o processo político que se desencadeia com sua presença e que tem como resultado final nossa independência política. (...) À longa permanência de D. João VI em terras brasileiras deve ser creditada, em

\footnotetext{
${ }^{45}$ Em texto que trata da formação do pensamento historiográfico no Brasil, Nilo Odalia ressalta o caráter elitista da produção historiográfica de Varnhagen: "Nosso estudo é sobre Varnhagen. Sobre o historiador que podemos considerar o fundador de uma corrente historiográfica brasileira, ainda hoje atuante, na medida mesmo em que em Varnhagen o pensamento burguês brasileiro encontrou o espírito que, embora a falta de imaginação, conseguiu realizar uma síntese admirável dos ideais e objetivos das classes dirigentes que tomaram a seu cargo a construção da Nação." (Odalia, 1997: 24). Outro trabalho que merece destaque por apontar a importância de Varnhagen na formação de um pensamento historiográfico brasileiro é o livro de Arno Wehling, aonde se afirma que "Os estudos mais relevantes a respeito do projeto conservador (1838-1856) podem ser destacados nesse período, a fim de evidenciar a ideologia de seu autor." (Wehling, 1999: 15).
} 
parte significativa, ao fato de nossa independência política não ter se realizado em termos de ideias e soluções revolucionárias. Pode-se atribuir, também, em parte, á sua presença o fato de nossa independência se realizar num vazio ideias, ligadas a um ideário político-filosófico que definisse ou, pelo menos, tentasse definir os rumos de uma nova Nação. (Odalia, 1997: 26).

De forma arguta Odalia reconhece o quanto pesou a presença longa da família real no Brasil, pois podemos identificar aqui o quanto essa permanência foi nefasta para possíveis projetos que tivessem, em sua base, a formação de uma sociedade “moderna e fiel ao liberalismo político anglo-saxônico." (Odalia, 1997). Todavia, não podemos desconsiderar que a independência vista por esse prisma corresponde a um pacto de consenso que manteve os princípios e interesses dos grandes proprietários, terras e escravos. Dessa forma, não haveria a possibilidade de que os grupos intermediários manifestassem o seu descontentamento com relação ao poder monárquico $^{46}$.

A ideia de constituição de uma Nação, para uma leitura que tem uma proposta oficial como é a de Varnhagen, esta definida desde seu "sopro inicial", ou seja, desde a chegada do europeu com seus valores da contra-reforma e da economia mercantil em propulsão na Europa. O Visconde de Porto Seguro acreditava que a formação dessa nação estava, não em medida considerável na participação do povo, mas sim no projeto oficial do Estado português.

Nesse sentido, a Nação será fruto direto de um construto preso a toda tradição colonial, não existe a possibilidade de uma recomposição sem o devido acerto de contas com o passado e o que nos foi instituído pela Metrópole. Se uma Nação não pode romper com esse tradicionalismo e surgir "nova", sem traços característicos de seu passado, torna-se tarefa primordial do historiador buscar configurar as características que fazem dessa ou aquela uma Nação.

A idealidade da nova Nação fica circunscrita às condições específicas da experiência histórica da sociedade nascida do sistema colonial, contudo e isto é muito importante, talvez decisivo, essa experiência é avaliada, limitada e corrigida, no interior do projeto em gestação, em razão da experiência histórica mais ampla e mais absorvente da civilização ocidental. (...) A história da colônia assim interpretada não é somente a história de uma conquista, pois isto ela o é efetivamente, mas ela é, prioritariamente, a constatação da superioridade de uma cultura, de uma civilização, de um modo de vida e de pensamento,

\footnotetext{
${ }^{46} \mathrm{O}$ historiador George Rudé afirma que: "O sistema de propriedade da terra na América Latina tinha a marca de suas origens coloniais, o que não é de surpreender. O padrão oficial era tripartido, e sua forma variou naturalmente de país a país, de acordo com características geográficas e geológicas muito diferentes. (Rudé, 1985: 93)
} 
sobre outras formas primitivas que acabam por ser interpretadas como um estado de barbárie. (Odalia, 1997: 45).

Varnhagen, pertencendo a um grupo de historiadores ${ }^{47}$ que "fundaram" as argumentações a respeito da história do Brasil, tem sua obra condicionada ao cenário em que a independência do país, já estava consolidada e necessitava de um discurso que explicasse e fundamentasse o surgimento da Nação. Seu livro inaugural foi possível, devido às condições históricas do Brasil, o processo de independência política e a constituição do Estado nacional "amadureceram nos anos de 1850" (Reis, 2005).

(...) E foi no interior desse processo histórico que ocorreu a outra condição favorável ao surgimento da obra de Varnhagen: a institucionalização da reflexão e da pesquisa históricas no IHGB. A independência política consolidada, e reprimida as lutas internas geradas por ela, o Brasil possuía um perfil do qual ainda não tomara conhecimento. Nos anos 1850, Varnhagen desenhará o perfil do Brasil independente, oferecerá à nova nação um passado, a partir do qual elaborará um futuro. (Reis, 2005: 26).

Francisco Adolfo Varnhagen era filho de um oficial alemão, engenheiro metalúrgico que trabalhava no Brasil, e de uma portuguesa. Em sua obra, ele faz acompanhar o seu nome das credenciais "visconde de Porto Seguro e natural de Sorocaba" (Reis, 2005). Entretanto, este paulista nobre morou pouco no Brasil, haja vista que residiu em Portugal desde os seis anos de idade. Sua formação, em Lisboa, foi mais militar, técnica e matemática. Mas estudou também paleografia, diplomática e economia política, porém temos poucas informações de sua formação intelectual. Capistrano de Abreu, que era admirador de Varnhagen no que diz respeito ao uso de fontes documentais para a escrita da história, no necrológio de Varnhagen afirmava que o "desconhecido o atraía" (Abreu, 1975a: 213).

A proposta de interpretação de Varnhagen a respeito da independência política do Brasil será um apanhado de elogios aos feitos de Portugal por realizar tão bem seu colonizador. Projeto que acabou, de forma definitiva, gestando um estado

47 Segundo José Carlos Reis: "Francisco Adolfo Varnhagen (1816-1878), é um dos fundadores da história do Brasil, mesmo se antes dele, entre outros, Pero Magalhães Gândavo, frei Vicente de Salvador, Sebastião da Rocha Pita, Robert Southey escreveram, respectivamente, História da província de Santa Cruz (1576), História do Brasil (1627), História da América Portuguesa (1730), História do Brasil (1810). Southey disputa com Varnhagen, sem nunca ter estado no Brasil, aquele título historiográfico. Ele pintou em sua História do Brasil um quadro sombrio quanto às possibilidades futuras da colonização comercial portuguesa no Brasil: degeneração dos costumes, da religião e da moral, causada pela escravidão e pela falta de agricultura - miséria, fome, turbulências, crimes, doenças. Varnhagen e os nativistas do IHGB se revoltaram contra esta apreciação negativa de Southey em relação à colonização portuguesa e ao futuro da jovem nação. Para estes, a colonização portuguesa teria sido um enorme feito, e o futuro estava aberto ao sucesso da nova nação. (Reis, 2005: 23). 
independente, que chegou a tal condição sem conflito ou derramamento de sangue. Com relação a essa análise, Wilma Peres Costa afirma:

A interpretação desenvolvida por Varnhagen para a formação da nação brasileira não apenas enfatizou as continuidades entre a Colônia e o período nacional, como atribuiu a essas continuidades conotação fortemente positiva: valorizava-se com ela a obra civilizadora da monarquia portuguesa e seu papel na construção da nação. O Brasil Independente colônia que amadureceu para se tornar nação sob a égide benevolente da mãe-pátria, expressava, em Varnhagen, a vitória da civilização européia sobre a barbárie autóctone. (...) A obra máxima do engenho europeu fora a apropriação e consolidação de um território, legado intacto à nova nação. A Independência, desse modo, inscrevia-se em uma espécie de ordem natural dos acontecimentos. (Costa, 2005: 58).

Varnhagen foi o primeiro historiador a utilizar os princípios conservadores, quando da constituição da Nação e da formação do Estado. O grande tema de seu livro é a obra da colonização portuguesa no Brasil. Embora monarquista, o que caracteriza sua obra não é esse aspecto, mas sim o colonialismo que defende e o conservadorismo que marca sua interpretação de nossa história. Era devoto de D. Pedro II, a quem deve sua carreira, mas seu livro é sobre a história colonial, não lhe dando oportunidade de revelar seu "monarquismo e bragantismo". (Rodrigues, 1988a: 14).

Queira ou não, o sentido da história do Brasil que transparece em sua obra revela seu posicionamento frente à escravização dos índios e dos africanos, na sua forma de pouco enfatizar a importância das rebeliões e insurreições, no projeto oficial da coroa portuguesa sempre em relevo, no pequeno destaque as grandes fomes e epidemias, enfim, em esquecer "o solo encharcado de sangue dos mais humildes e modestos." (Rodrigues, 1988). Para seguirmos um pouco mais o argumento de José Honório Rodrigues, que identifica em Varnhagen um exemplo do pensamento historiográfico conservador, destacamos da obra deste último, a proposta continuista do monarquismo, não permitindo qualquer formulação identificada com os anseios liberais e modernizantes. Assim, diz Varnhagen:

Politicamente sou monarquista por fortes convicções, admiramos também a bela instituição das nossas assembléias ânuas, fomentadoras da integridade da nação, atalaias do seu governo e rebelamo-nos sempre contra todo o exclusivismo de poderes, contra toda absurda tirania, contra todo arbitrário absolutismo, para donde parta. Socialmente, quanto aos Índios e Africanos, cremos que devêramos ser justos e mais humanos do que se é geralmente. Somos de opinião que estamos sendo no país injustos com aqueles, por cruel filantropia, com desvantagens do estado que podia e devia aproveitar dos seus braços; e com os últimos, por excesso de rigor, sem nenhuma inutilidade pública, nem particular. Inclinamo-nos a que deveriam os primeiros ser submetidos e avassalados, e entregues a uma espécie de clientela, resolvendo-se isso nobremente e sem hipocrisias, e os segundos ser melhorados na sua condição social; convertendo 
também a escravatura em clientela, embora continue esta vitalícia e hereditária, e isto pelo simples meio de acabar com as compras e vendas. Civilmente somos defensores dos prestígios honoríficos, com que em proveito do Estado os governos tiram partido da natural vaidade humana; somos advogados da criação; independentemente das academias que existem, de uma Universidade central, ou pelo menos de uma escola politécnica; propendemos a considerar, o sacerdócio a instrução primária e admiramos o sistema de certas escolas gratuitas para o estado, que tem produzido profícuos resultados em outros países; e não disfarçamos as nossas inclinações à colonização empreendia por conta dos particulares e não do governo, a um sistema tributário menos indireto, começando pelo censo territorial, a outra forma de recrutamento. (Varnhagen, 1962: 12).

Sendo refratário a qualquer proposta de caráter liberal e modernizadora para a sociedade o seu conservadorismo fica latente no trecho acima citado, ou seja, suas referências em relação à suposta integração social de indígenas e africanos, identificando nesses um grupo subalterno e sem possibilidade de oferecer à sociedade qualquer tipo de contribuição. Na visão de Honório, "o absolutismo é irmão gêmeo do colonialismo e sua obra, louvando o colonialismo português, exaltava o absolutismo que o acompanhava." (Rodrigues, 1988a: 19).

Dessa forma, com sua contumaz avaliação dos fraquejos e limites da obra de "nosso Heródoto", José Honório Rodrigues expõe que essa vertente fundante do pensamento historiográfico não apresenta um projeto de formação da Nação que rompesse com os entraves e obstáculos instituídos por anos de colonização portuguesa. Nessa perspectiva, a "Casa de Bragança", responsável pela condução da independência do país, deixa resquícios de difícil superação e acaba encontrando em intelectuais, da monta de um Varnhagen, o discurso afinado para constituir uma "história oficial" da Nação ${ }^{48}$.

(...) Se da união nasce a força, da desunião somente fraqueza resulta; e o maior ascendente que em todos os países tem tido a civilização sobre a barbárie vem de que esta, composta de elementos dissolventes, não se une, ao passo que a Nação civilizada (grifo nosso), que com ela se põe em contacto, tem nas suas mesmas leis os laços de união. (Varnhagen, 1962: 457).

A base das concepções colocadas em prática por Varnhagen, e que versam a respeito da tentativa de conhecer e interpretar o Brasil, apresenta de forma majoritária, traços de um pensamento de caráter conservador. O domínio conservador

48 Em seu estudo a respeito da obra de Varnhagen, afirma Nilo Odalia: “A escolha do que deverá ser a nova Nação acaba por parecer como a natural decorrência de uma situação histórica em que oposição entre culturas e civilizações diferentes acaba por impor um vencedor - a cultura e a civilização dos brancos, que traz em seu arsenal de armas não só as de natureza guerreira, como também outras, mais efetivas e sofisticadas, vistas como atributos de uma civilização superior" (Odalia, 1997: 46). 
das minorias foi sempre tão grande e contínuo que as classes médias e trabalhadoras, escravas primeiro e livres depois, "revelaram sempre uma deferência, um respeito, um acatamento para com seus superiores, que não só amoleceram as lutas de classes, como mantiveram no seu devido lugar as classes sociais majoritárias". (Rodrigues, 1988a: 1). Essa referência constante mantém o tradicionalismo e o conservadorismo político, tendo se preservado no Império e na política colocada em prática ao longo do período republicano.

A superioridade das forças tradicionais não só decresce, como seus valores dominantes são postos em dúvida e as ambigüidades se acentuam. A participação política tem crescido, mas não de forma a abalar a força e autoridade das minorias dominantes. O problema central se concentra na resposta que os membros subordinados dão aos valores poderosamente disseminados para apoiar os interesses das classes dominantes. Em que condições respondem os subordinados aos valores que parecem apoiar os interesses de sua própria classe e sob que condições eles se submeterão aos valores dominantes? (Rodrigues, 1988a).

A interrogação de José Honório é pertinente quando observamos como esse conservadorismo se mantém e se encastela nas formas de ação política de nossa elite dirigente não permitindo, ao longo da História do Brasil, qualquer forma de participação ativa das camadas subalternas na vida política do país. Para reforçar esse conservadorismo os "setores dirigentes", como denomina José Honório a elite que exerce o controle político do país, não tem preocupação em criar um vínculo que procure conciliar um projeto político com os anseios históricos do povo brasileiro. Desse modo, para que haja a continuidade de sua supremacia é necessário que as formas de interpretação e leitura da realidade brasileira estejam escoradas nessa lógica de dominação.

O conservadorismo depende não só da posse da força do capital e militar, mas psicologicamente dessa deferência que mantém a dominação. Os valores dominantes e subordinados se movem dentro de conceitos cívicos mais gerais e representam inequivocamente valores políticos opostos. $\mathrm{O}$ valor dominante na cultura política é o que se pode chamar tradicionalismo, com algumas complicações recentes resultantes de valores tecnológicos e o principal valor subordinado aparecendo na forma de igualitarismo. (...) O conservadorismo sempre defendeu a tese de que a história seria favorável às fases em que o poder foi exercido por estadistas sectários do princípio da autoridade e não pelos partidários do liberalismo, mais ardente e generoso que refletido. (Rodrigues, 1988a: 22).

O pensamento conservador esteve sempre associado ao medo da mudança e a uma ferrenha resistência a mesma. Aspecto que caracterizou a nossa 
política ao longo da história e maculou a atividade e o pensamento liberal brasileiro. História essa também dominada "pelo temor das grandes mudanças, como foi no processo de abolição da escravidão" (Rodrigues, 1988a). Além disso, reconhece em Varnhagen o mérito de trazer à discussão a importância de trabalhar com documentos e dar espaço para a construção histórica com base nesses dados documentados. Porém, a crítica honoriana está centrada principalmente quanto ao caráter ideológico e cifrado de tais documentos, pois "trata-se de documentos oficiais, não oferecendo espaço para uma crítica maior e uma história que não estivesse comungada com o tradicionalismo da sociedade." (Rodrigues, 1988a).

Quem ler a História Geral do Brasil verá que, neste país, durante a Colônia, o grande problema foi sempre o de garantir e assegurar os direitos da maioria contra os abusos da minoria possuidora do poder e da riqueza. Perseguição política e religiosa, discriminações raciais, censura, absolutismo, falta de ensino, de imprensa, somam-se aos excessos dos castigos exemplares dados às maiorias conservadas sempre em estado de minoridade política e cívil. Abusos de autoridades, lutas entre governadores e magistrados, corrupção e relação das minorias dirigentes com o povo, a sociedade - governos longos, de 30, 25, 15 anos não são exceção - dão à História Geral do Brasil um sentido revelador: o historiador conservador não consegue ocultar as mazelas do colonialismo português. (...) O longo e sinuoso caminho colonial da história do Brasil não foi escondido por Varnhagen. Não é surpresa que um homem tão solidamente fortificado na sua ideologia conservadora e na sua prática pragmática, que jamais colocou o debate no terreno abstrato e absoluto da Justiça, mas no da convivência e da utilidade deixasse ocultas as fraquezas essenciais do colonialismo. E não é surpresa porque não é só forte a sua convicção de que serve à verdade, como toda a crítica moderada ao colonialismo não aparece em conjunto, mas parceladamente. (Rodrigues, 1988a: 27).

Essa contradição na obra de Varnhagen pode ser exemplificada em seus argumentos em favor do regime escravista. $\mathrm{O}$ autor aceita como lícita a escravidão e argumenta que havia a necessidade de implemento da prática entre nós, pois foi através da força de trabalho escrava que fora criada a base da organização social do país . Além disso, as resistências dos povos subjugados, como as insurreições, sempre foram alvo de suas severas críticas. Tal autor evidenciou, também, sua aversão aos movimentos de caráter questionador por parte de setores contrários ao governo monárquico.

A respeito da Revolução de 1817 , ele pede ao leitor que decida em consciência se lhe parece que havia motivos para que se intentasse uma revolução contra o benéfico Sr. D. João e declara ser um assunto para seu ânimo tão pouco simpático que se lhe fora permitido passar sobre ele um véu, o deixaria fora do quadro que se propusera traçar; mas, forçado a dedicar-lhe algumas linhas, procurara ser breve. (...) Varnhagen estava consciente dos dissabores que sua reprovação the custaria, mas escreve com altivez e dignidade que maiores seriam os do espírito capitulando covardemente contra as próprias convicções. A missão do historiador não é lisonjear, nem adular a ninguém, e menos aos 
vivos no país, ou antes, neste a meia dúzia de gritadores apaixonados e parciais. (Rodrigues, 1982:143).

A obra de Varnhagen procura ressaltar um projeto de Estado próximo aos interesses dos setores que controlam a sociedade e apontam para uma nova forma de entendimento da empreitada colonial de Portugal. Assim, não existe um distanciamento entre os interesses lusitanos e a forma como o autor de História Geral do Brasil conduz o seu estudo a respeito da organização que a sociedade brasileira teve e o estado que acabou sendo plasmado entre nós.

$\mathrm{Na}$ Brasil, os fundamentos de suas posições podem ser rastreados na ideologia do Regresso e no conservadorismo da década anterior, a partir da Assembléia Constituinte. Elas assumem papel semelhante ao das ideias liberais que circulavam na Europa após a restauração: um Estado de laissez faire no plano econômico, mas efetivamente gendarme no plano social e político, isto é, mantenedor do status quo institucional, assegurado pelo controle do poder político pelos proprietários através do sufrágio censitário e indireto. (Wehling, 1999: 88).

Nesse sentido a particularidade da análise de Varnhagen encontra-se nas contradições mais evidentes da sociedade colonial. Ou seja, a forma limitadora com que apresentava as escassas instituições públicas, em muitos aspectos, até mesmo inexistentes; bem como o modo como abordava as populações marginalizadas, isto é, os homens livres pobres, habitantes da área rural, não cidadãos e escravos ${ }^{49}$. Os limites que José Honório identifica em Varnhagen podem mostrar o quanto aquele estava interessado em questionar a postura intelectual de autores que se afastavam de uma identificação da realização de feitos do povo e daqueles que representavam os setores subalternos.

O pensamento conservador, que representa a vinculação das práticas do período monárquico, é uma formulação com base tipicamente histórica e social, que teve seu surgimento num contexto peculiar. Recuperando a argumentação clássica de Mannheim:

\footnotetext{
${ }^{49}$ Em estudo clássico a respeito do tema, Maria Sylvia Carvalho Franco argumenta que: "As condições de existência das camadas inferiores da população rural livre, no Brasil, não favoreceram a cristalização das relações de trabalho. Deve-se considerar que o povoamento do interior fez-se pela disseminação de pequenos grupos esparsos em um amplo território e que a grande disponibilidade de terras férteis e a riqueza das fontes naturais de suprimento, aliadas à pobreza das técnicas de produção, definiram um modo de vida seminômade, baseado numa agricultura itinerante cujos produtos eram suplementados pela caça, pesca e coleta. Pode-se dizer que, ao longo de sua história, esses grupos só tiveram reforçada essa grande instabilidade. Até o presente, observa-se que a mobilidade lhes aparece como o único recurso contra condições adversas de existência: problemas com patrão, salário baixo, trabalho insalubre, desavenças, desgostos resolvem-se ainda hoje com transferência de domicílio. (Franco: 1997: 32).
} 
Enquanto o tradicionalismo é uma daquelas tendências virtuais que cada indivíduo inconsciente abriga em si mesmo. $\mathrm{O}$ conservantismo é consciente e reflexivo desde o início, pois surge como um movimento consciente e reflexivo desde o início, pois surge como um movimento consciente de oposição ao movimento "progressista" sistemático e coerente, dotado de uma organização extremamente desenvolvida. (...) O surgimento de um movimento conservador consciente já é, portanto, uma indicação de que o mundo intelectual e social moderno desenvolveu uma estrutura particular própria. A mera existência do conservantismo como uma tendência coerente significa que a história está desenvolvendo-se cada vez mais nos termos da interação de tais tendências e movimentos abrangentes, alguns dos quais são progressistas e estimulam a mudança social, enquanto outros são reacionários e a retardam. (Mannheim, 1982: 113).

Esse aperfeiçoamento de determinadas tendências nada mais é que o resultado de um aprimoramento societário, que levou, inexoravelmente, a compartimentações no campo reflexivo, à medida que existia a superação de uma ordem anterior, no caso do Brasil a estrutura colonial, sem uma vida dinâmica que amplie as relações de capital, ou mesmo, procure romper com o período anterior. O historiador Caio Prado Junior nos auxilia a compreender o período afirmando que:

O Império independente, que sob muitos aspectos não será mais que um prolongamento da situação anterior (conservar-se-á até mesmo a dinastia reinante em Portugal, sendo coroado imperador o herdeiro presuntivo da coroa portuguesa), nada alterará. Permanecerão os mesmos quadros administrativos, na maior parte das vezes até as mesmas pessoas; e os processos não se modificarão. Tudo isto até certo ponto se explica - embora sem eliminar os danos financeiros e econômicos resultantes. Não era evidentemente possível governar e administrar uma nação independente e soberana, prenhe de necessidades até então inatendidas, com o rudimentar aparelhamento administrativo da colônia, onde a justiça era um mito, a ordem legal precária, as forças armadas reduzidas e sem organização eficiente, a saúde pública, a instrução, os serviços de fomento quase nulos, as relações externas inexistentes. (Prado Jr, 1980: 138).

Essa particularidade no que diz respeito ao desenvolvimento das condições de consolidação do liberalismo político ficou impossibilitada, mesmo o liberalismo econômico ficou limitado às restrições do Estado brasileiro ${ }^{50}$. Nesse sentido, a "consciência limite" que procura uma maior dinâmica e modernização do Estado segue as premissas delineadas por Mannheim: "Estabelecimento da unidade nacional, a

\footnotetext{
${ }^{50}$ No cenário político como o brasileiro, o professor Florestan Fernandes afirmava que: "É patente que o liberalismo forneceu, não obstante todas as limitações ou deformações que pairaram sobre sua reelaboração sociocultural no meio brasileiro, as concepções gerais e a filosofia política que deram substância aos processos de modernização decorrentes, primeiro, da extinção do estatuto colonial e, depois, da desagregação lenta e heterogênea, mas progressiva, da própria ordem colonial. Ele não afetou (nem poderia afetar) os aspectos da vida social, econômica e política que continuaram a gravitar em torno da escravidão e das formas tradicionais de dominação patrimonialista. (Fernandes, 2006: 55).
} 
participação do povo no governo do país, a incorporação do Estado na ordem econômica mundial e a solução das questões sociais." (Mannheim, 1982).

Esses são pontos fundamentais para a melhor organização da vida social de um determinado Estado. Tal como ocorre em relação à sociedade e poder, a ponto de existir certa tendência de todas as divisões dentro dela para se desenvolverem em estreita relação com as tensões que surgem durante as tentativas de solução de problemas fundamentais da estrutura social. Nesse sentido, é fundamental a compreensão do desenvolvimento desta tendência de generalização e consolidação do pensamento conservador, principalmente devido ao "caráter dinâmico do mundo moderno e esta dinâmica estando pautada pela diferenciação social, sendo esta a responsável em arrastar consigo o intelecto humano. (Mannheim, 1982: 115).

No caso da sociedade brasileira, segundo a precisa formulação de Nilo

Odalia:

Numa jovem Nação, onde são visíveis os sinais de seu passado colonial, esperase que um Estado forte e homogêneo seja a resposta correta a todas as incertezas de uma unidade nacional antes projeto do que realidade; de uma nacionalidade cujos pródromos podem ser esmiuçados e identificados, mas que dificilmente afloram à consciência popular; de uma população híbrida, de raízes étnicas diversas, cujos olhos não alcançaram mais que os limites de suas propriedades e quando ultrapassam o fazem apenas para cair na melancolia de terras do alémmar; uma população cuja característica fundamental é a de ser dividida entre senhores e escravos, brancos e negros, brancos e índios, negros e índios permeada pela mestiçagem geral; uma massa heterogênea onde a única relação efetiva, obrigatória e necessária, é a que decorre do regime de trabalho, que a aproxima e afasta em igual intensidade de uma população diferençada e conflitante na qual não se pode ver um povo, mas tão somente a possibilidade de um povo, e, assim mesmo num futuro incerto. (Odalia 1997: 64).

Resistente as exigências populares, o pensamento conservador, aqui representado pela figura de Francisco Adolfo Varnhagen, sempre procurando soluções práticas para as condições sociais que lhe são impostas, além de representar os interesses da elite dirigente. José Honório Rodrigues identificou de forma precisa essa característica na obra do Visconde de Porto Seguro - sem deixar de ressaltar a contribuição para a pesquisa histórica.

No volume 2 tomo 1 de História da História do Brasil, a preocupação em apontar a produção historiográfica que procura sempre negar os movimentos de ruptura da sociedade, mantendo uma aproximação "com o conformismo do povo", justificando os fracassos "como erros humanos e não pela falta de reformas" (Rodrigues, 1988a: 7). Dessa forma, a proposta nacionalista-liberal de Honório aqui se 
mantém, pois sua meta é apontar os limites que esses intelectuais tinham ao elaborar a produção que inaugurava a historiografia no país, a proposta interpretativa deixa evidente o tipo de interpretação da História do Brasil foi privilegiada. Sua escolha só reforça o traço conservador de sua obra.

\section{4 - História viva: A ESG e a adesão ao nacionalismo liberal.}

Neste item pretendemos destacar a trajetória de José Honório Rodrigues, primeiro, como estagiário da Escola Superior de Guerra (ESG), depois, como conferencista, isto é até 1964, quando, após o golpe militar, deixou de ter participação ativa dentro da referida instituição. Outro objetivo é identificar o contexto intelectual daquele lócus, haja vista que se trata de um espaço que muito influenciou o historiador o intelectual carioca.

Nesse sentido, pretendemos entender qual era o "clima" intelectual da ESG dado que, durante a sua passagem, José Honório Rodrigues afirmasse que ali sofrerá uma "bofetada de brasilidade", referindo-se as discussões que se faziam presentes. Outro ponto a ser destacado é a ideia de "historiador do presente", ou seja, a necessidade de análise da "história viva". Essas foram as preocupações teóricas e metodológicas que José Honório Rodrigues passa a mencionar depois de seu contato com a ESG.

A ESG seguia a seguinte organização, nos explica o intelectual carioca:

Sobre a Escola Superior de Guerra não falo apenas como conferencista. Fui estagiário em 1955 e, desde 1956, conferencista anos seguidos. Para mim, pessoalmente, e acredito que para outras pessoas civis ou militares, o curso teve uma influência duradoura. A primeira parte é introdutória à ciência política, ou melhor, às ciências sociais, e no meu caso, como no de outros, é muito secundário, sem interesse, mas acredito seja útil aos estagiários militares. A segunda parte é sobre a conjuntura nacional, e esta é, para mim, a grande contribuição que a Escola oferece a todos, pois os atualiza sobre os problemas brasileiros. Em 1955, sem a implantação do regime autoritário, a liberdade na escolha dos conferencistas era muito grande e assisti a esplêndidas conferências com uma visão muito crítica da situação brasileira. A terceira parte do curso da ESG era sobre a conjuntura internacional, dada somente pelo ministro das Relações Exteriores e pelos chefes de departamentos específicos. Daí o oficialismo da exposição, o que tornava desfigurado o quadro político internacional. (Rodrigues, 1985: 131).

Em entrevista à revista Isto É, o próprio José Honório Rodrigues explica por que sua passagem pela Escola Superior de Guerra, primeiro como estagiário e depois como conferencista, lhe afetou de forma definitiva a produção intelectual, pois 
todo aquele cenário lhe serviu como uma "bofetada de brasilidade". A metáfora significa que o mundo do especialista estava sendo revirado por um sopro de realidade nacional, que o "convocava em nome da História", significando um meio caminho entre o engajamento sectário e a alienação distanciada. Fica claro que a meta não era mais somente compreender a História, mas poder acioná-la em prol das transformações políticas e sociais que se impunham, mais do que nunca, no campo dessa experiência seria, cada vez mais, procurar o melhor entendimento da História do país. Para o entendimento dessa passagem pela ESG e, segundo as próprias argumentações do historiador, compreender os elementos que explicam a mudança expressiva na obra honoriana. Cabe ressaltar que a própria "Escola" sofrera mudanças, que podem ser compreendidas como alterações que ocorrem mundialmente e que ressoaram na organização das Forças Armadas no Brasil.

As mudanças pelas quais a sociedade brasileira passava a partir do decênio de 1950 e o impulso do nacional desenvolvimentismo no período acabaram acarretando à reformulação do Estado de compromisso montado por Getúlio Vargas que culminaria na industrialização acelerada do governo de Juscelino Kubitschek ${ }^{51}$. O cenário mencionado apresentava, nas fileiras do exército, uma disputa entre grupos antagônicos que se posicionavam diante das discussões sobre o projeto de segurança nacional. Nesse sentido, Antonio Carlos Peixoto afirma que:

O conceito de segurança nacional não possuía o mesmo sentido para as duas correntes que se defrontavam. Para os nacionalistas, a segurança residia, antes de qualquer coisa, na possibilidade de um desenvolvimento nacional afastado dos grandes centros de decisão do capitalismo internacional e sustentado por rigorosa mobilização popular. Para os antinacionalistas, grupados em torno da ESG, a segurança nacional possuía implicações diferentes. Seu ponto de partida era dado pela divisão irremediável do mundo em dois blocos hostis, isso forçava o Brasil a buscar suas alianças no bloco ocidental. (Peixoto, 1980: 87).

A discussão a respeito da segurança nacional devia levar em conta esse inimigo interno que se manifestava através da guerra revolucionária. Um cenário de enfrentamento e de intensificação das lutas ideológicas ficava cada vez mais claro para os representantes da ESG. A conduta da instituição visava agrupar dentro de suas fileiras, ambos os setores que compunham os lados da polêmica, para ter maior possibilidade de uma coesão. No intuito de enfrentar as ameaças, a mobilização e a coesão das elites eram indispensáveis. Mas, se a Doutrina de Segurança Nacional

\footnotetext{
${ }^{51}$ Para maiores detalhes a respeito do Estado de compromisso de Getúlio Vargas e da industrialização do período Juscelino Kubistchek, ver: (Bielschowsky, 2000).
} 
forneceu um instrumento ideológico capaz de congregar certo número de oficiais em torno do seu princípio, o nacionalismo jamais chegou a produzir uma doutrina elaborada dentro das Forças Armadas. Diz a respeito Antonio Carlos Peixoto:

Os grandes teóricos do nacionalismo são encontrados fora das Forças Armadas, e o aparelho ideológico dos grupos nacionalistas e militares jamais teve no interior das Forças Armadas uma influência e um poder comparáveis aos da ESG. As diferenças entre a Doutrina de Segurança Nacional e as bases ideológicas do nacionalismo determinam em certa medida e evolução do tipo de relações com os grupos civis. O nacionalismo não era uma ideologia especificamente militar; comportava em sua aplicação uma direção civil capaz de mobilizar as camadas populares. Para as correntes nacionalistas, a questão da hegemonia das Forças Armadas dentro da coligação nacionalista nunca foi considerada indispensável. Essa hegemonia poderia se revelar, mas de maneira acidental, no caso em que os grupos civis devessem apelar para o aparelho institucional de violência. Em troca, a questão da hegemonia militar tornava-se mais explícita para o grupo antinacionalista da ESG. (Peixoto, 1980: 88).

A ESG foi oficialmente inaugurada em 1949, a fim de ser o equivalente brasileiro ao National War College americano. Incorporou as ideias e as atitudes maniqueístas dominantes no sentido internacional da Guerra Fria. Como uma instituição, a ESG encorajou, dentro das Forças Armadas, normas de desenvolvimento associado e valores empresariais, ou seja, um crescimento cujo curso industrial foi traçado por multinacionais e um Estado guiado por razões técnicas em detrimento da política. O Estado adotado ganharia uma estabilidade através da condução política e a utilização dos princípios da Doutrina de Segurança Nacional. Segundo René Dreifuss:

Ideologias americanas de "construção nacional" foram disseminadas entre as Forças Armadas Brasileiras e reforçadas pela doutrinação empresarial. Nesse período a ESG constitui-se um dos principais foros utilizados por empresários para a doutrinação de oficiais das Forças Armadas e de técnicos selecionados quanto a racionalidade de um modelo de desenvolvimento empresarial associado, doutrinação esta feita através de debates e documentos, em sua maioria confidenciais. (Dreifuss, 1986: 79).

Dentro da "Escola" havia a discussão de um conjunto de ideias baseada na aceitação de premissas sociais, econômicas e políticas que raramente se faziam explícitas além de visão estática de uma sociedade eternamente dividida entre elite e massas. Este sistema de ideias, que se reproduziu no interior de uma formação sócioeconômica especifica, encontrava a sua "razão de ser" em relações supostamente permanentes e mesmo naturais de posse e "apropriação privadas." (Dreifuss, 1986: 82)

Ainda utilizando o texto de Dreifuss:

Essa linha de pensamento excluía teoricamente e evitava praticamente qualquer transformação estrutural, permitindo, no entanto uma modernização 
conservadora. Tal abordagem excluía também a presença de representantes das classes trabalhadoras, ou mesmo das camadas intermediárias, no quadro de professores regulares ou convidados da ESG. O argumento em prol do desenvolvimento era apresentado na ESG somente por empresários, tecnoempresários e, em menor escala, por políticos, assim por convidados, tanto civis como militares. (Dreifuss, 1986: 83).

A ESG escolheu os setores sociais nos quais penetraria, assim como os métodos de penetração e articulação política. Ela atua junto a um grupo social restrito, de formação universitária obrigatória, composto por pessoas pertencentes a "burocracia estatal e privada" (Oliveira, 1987). Na área militar, a ESG opera com oficiais superiores que já passaram pela formação do Estado Maior em suas respectivas “Armas” (Exército, Marinha e Aeronáutica) e que obtêm na ESG a única experiência prevista em suas carreiras no tocante à preparação de ação conjunta ou combinada entre as três "Armas" ao nível de comando: o Curso de Estado Maior e Comando das Forças Armadas. Este curso é de acesso exclusivo a militares, enquanto que o Curso Superior de Guerra recebe também estagiários civis. Eliezer Rizzo de Oliveira argumenta que:

Enquanto instrumento de relação orgânica entre setores militares e grupos ou setores de classes dominantes, entre grupos militares e outros setores do aparelho de Estado com o objetivo de promover um determinado tipo de desenvolvimento econômico (de tipo capitalista), dirigido por um grupo especifico (as elites) e dotado de uma ideologia (Ideologia de segurança nacional) e de uma opção estratégica (o Mundo Ocidental), sob a hegemonia dos Estados Unidos. (...) Cabe destacar que a ESG não foi simplesmente transplantada da experiência americana, com a qual manteve uma dupla relação: uma inspiração inicial correspondente à expansão da hegemonia global dos Estados Unidos; uma adaptação diferenciadora, posto que as "elites civis" (tivessem ou não postos nas estruturas do Estado) foram procuradas, desde o início, para participar da ESG como estagiários ou membros do Corpo Permanente. (Oliveira, 1987: 60).

Neste sentido, a dinâmica que a Escola Superior de Guerra vinha adquirindo desde seu período de formação leva-a a apresentar, dentro de suas fileiras, um projeto de desenvolvimento da sociedade, incorporando inclusive formas de desenvolvimento do setor industrial. Destarte, procurava frear qualquer discussão que pudesse levar à radicalização na sociedade. Todavia, esse contexto não impediu José Honório de reconhecer a validade de seus cursos voltados à "realidade brasileira". Num relato de sua passagem pela ESG, faz a seguinte referência:

$\mathrm{Eu}$ me formei pela ESG em 1955, quando o Departamento de Estudos era dirigido pelos então coronéis, Jurandir Bizarria Mamede e Golbery do Couto e Silva. Fiquei surpreso com o conhecimento dos dois. Falavam como professores universitários e citavam livros, artigos de revistas especializadas angloamericanas e francesas, que muitos professores não costumavam conhecer. 
Notei em ambos uma concepção de classe média, tendendo para a direita. (Rodrigues, 1986: 143).

Na visão de José Honório Rodrigues, por um lado havia a concepção que a ESG mantinha nos anos iniciais, isto é, o fato de ser, "crítica, aberta e democrática" (Rodrigues, 1986) e por outro lado o posicionamento a partir de 1964, haja vista que, segundo o autor, a partir desse momento teria se tornado um instrumento do Estado autoritário, sendo controlada por uma elite tecnocrata-militar que via no povo brasileiro um inimigo interno a combater. Questionado pelo entrevistador a respeito de sua influência no ideário da ESG:

Não tive nenhuma influência na doutrina da Escola. Pelo contrário, ela é que teve em mim. Andava por essa época seguindo um rumo erudito, e a Escola foi uma grande abertura que me sacudiu, revelando a realidade brasileira contemporânea. O que escrevi depois de 1955 tem um sentido de participação no presente como nunca teve antes. Desde então liguei muito mais a história ao presente e compreendi melhor o que Croce, por influência hegeliana, ensinara que a história é sempre história contemporânea, é sempre presente. A história é viva. Em 1964, ainda fui convidado a fazer conferências na ESG, como fazia todos os anos, desde 1956, mas o rumo autoritário, antidemocrático, que assumiu o movimento de 1964, um contra-revolução, me levou a assinar vários manifestos, quando se pensava que manifesto podia influir nos rumos dos acontecimentos. (grifo nosso) (Rodrigues, 1986: 144).

O posicionamento adotado a partir do golpe militar de 1964 expõe, além do afastamento de José Honório Rodrigues do vínculo ideológico da ESG, a ruptura com uma instituição que não mais representava a possibilidade de discussões acerca do projeto nacionalista, tal como defendido por Honório. Cabe destacar que a ESG, naqueles anos, apresentava um projeto que estava em consonância com todo o cenário político e social do país, ou seja, tentava esboçar um projeto de Nação que não colidisse com o interesse das elites, pois se temia que o nacional-desenvolvimentismo pudesse sair do controle e tornar-se uma força ideológica forte e contrária às necessidades da elite local.

A ESG representava as tensões que a sociedade como um todo enfrentava. Dessa forma, nacionalismo e anti-nacionalismo havia se tornado os dois polos políticos no âmbito da instituição. Além disso, a articulação e os embates entre esses dois grupos antagônicos foi uma constante desde 1945 a 1964, representando, inclusive as disputas que ocorreram no cenário político brasileiro, levando, em alguns casos, a participação de setores do exercito. 
É nesse ambiente que a ESG, desde sua formação em 1949 até o golpe militar de 1964, mantinha uma coexistência entre setores militares e civis, essa relação visava a criação de um discurso comum - civil e militar -, também de cunho político, com o objetivo de pensar o Brasil tanto em uma perspectiva interna como externa, enfatizando as necessidades e os obstáculos que se colocavam para que o país iniciasse uma trajetória de desenvolvimento em todas as suas dimensões. Esse posicionamento almejava adotar uma determinada forma de ação que correspondesse à própria tradição do exército brasileiro, haja vista que dentre suas atribuições típicas estava o papel de Poder Moderador. A esse respeito argumentou Alain Rouquié:

O Exército brasileiro costuma atribuir-se no sistema político um "Poder Moderador" análogo ao soberano no tempo do Império, tem estado presente em todas as reviravoltas da história nacional e apresentando peso determinante nos períodos de crise. Foi o velho Exército de Deodoro da Fonseca e de Floriano Peixoto que instaurou a República em 1889, antes de entregar a direção da coisa pública aos civis. E foi ele também que deu fim à República oligárquica, em 1930. Foi ele igualmente que permitiu em 1937 a instauração, pela força da ditadura centralizadora, do Estado Novo de Getúlio Vargas. E o exército, que sustentou essa experiência autoritária, chegado o momento, em 1945, depôs Vargas e estabeleceu um sistema democrático. Vigilantes, mas aparentemente inconsequentemente, os fiadores "da ordem e do progresso" se opuseram em 1945 e 1961 às autoridades legitimamente eleitas, mas em 1955 voaram em socorro da Constituição. (Rouquié, 1980: 11).

Era essa instituição, portanto, extremamente atuante ao longo da história da sociedade brasileira, que foi determinante para a mudança de atitude de José Honório Rodrigues a partir dos anos de 1950. A possibilidade de confrontar determinadas propostas de cunho ideológico e, o encontro com referências expressivas da intelectualidade de então foi elemento determinante para a exacerbação do ideário nacionalista que, ao nosso entendimento, representava uma vertente que iremos definir como um nacionalismo-liberal que o pensador carioca passou a defender naqueles anos.

A relação que esse ideário apresenta com a passagem pela ESG, ao nosso entendimento, é devido à preocupação que ocorre em pensar os rumos que o país tomaria com a passagem de dois governos de forte caráter nacionalista (Getúlio Vargas e Juscelino Kubistchek). Além disso, há a possibilidade, aventada por aqueles governantes, de uma conciliação com o povo, bem como a instalação de uma sociedade que procurava seu desenvolvimento econômico, ou seja, a instituição de um setor industrial que pudesse formar setores de produção significativo e urbano. A introdução 
do capitalismo industrial seria a premissa para que a "via americana" de desenvolvimento pudesse ser identificada. Assim afirma José Honório:

Os Estados Unidos constituem a única sociedade na América em que o rompimento com o passado e com a estrutura colonial foi total: o povo esperou e recebeu terras, subsídios, estradas e muitas melhorias do governo. Na América Espanhola e no Brasil, um governo semicolonial, pobre, pouco dava, e era dominado pela oligarquia rural. (Rodrigues, 1970: 24).

O contexto histórico propunha uma mudança vertiginosa na sociedade brasileira. A respeito da produção intelectual da época, Carlos Guilherme Mota aponta:

Não será exagero afirmar que, nesse momento, encontram-se alguns divisores de águas, com os traços significativos das principais tendências do pensamento histórico, político e cultural no Brasil. Cada tendência corresponde a uma vertente importante da maneira pela qual os historiadores se debruçam sobre a realidade do país. O planejamento desenvolvimentista, típico do período juscelinista, estará representado na obra de Celso Furtado; a concepção culturalista; no livro de Sérgio Buarque de Holanda; o nacionalismo estará expresso no ISEB (Instituto Superior de Estudos Brasileiros), embebido nas teorias dualistas de explicação da "realidade nacional" (as "soluções adequadas à realidade nacional"), acolhendo tanto as análises marxistas ortodoxas de Nelson Werneck Sodré, como as veiculadoras por vezes da ideia do progressismo da "burguesia nacional", como as de Wanderley Guilherme dos Santos e Ignácio Rangel; os textos de José Honório Rodrigues representariam, nesse contexto, a vertente erudita do trabalhismo getulista, opondo-se de maneira candente à produção elitista dos Institutos Históricos e Geográficos, e ao saber esclerosado - um "modernizador" nacionalista e pugnador do revisionismo historiográfico. Hélio Vianna, representando a abordagem tradicionalista e arcaica, pode ser considerado a antítese do revisionismo de José Honório Rodrigues. (Mota, 2008: 78).

A ideia de que o legado intelectual honoriano representaria uma vertente do "trabalhismo getulista" visa dar maior precisão à peculiaridade da obra de José Honório Rodrigues. Com relação ao nacionalismo e ao modo como este passa a balizar a formulação do autor para a democracia no Brasil, há que se ressaltar que:

Getúlio Vargas trouxe novos elementos, conservando qualidades tradicionais, como a compostura, a dignidade do cargo, a serenidade da presença. Ele não era membro de uma classe privilegiada, nem havia sido nomeado pela máquina dos velhos Partidos, mas sua atração podia consistir, talvez nas ideias de justiça social - novas, então, especialmente ao proletariado. Não era um tribuno, mas usava da linguagem direta e do senso comum. Desde então a luta entre os vários Brasis - melhor simplificado nos dois de Jacques Lambert, o arcaico e o novo rompeu o caráter altamente individualizado da sociedade tradicional. A nova fase representava, desde então, a emergência de novos tipos de personalidade, de novas formas de apelo, de novos atores. (Rodrigues, 1970: 28).

Do ponto de vista tipicamente histórico, a discussão a respeito do nacionalismo de um determinado povo, ou grupo social tem origens no século XIX, mas 
precisamente no momento em que as manifestações que se propunham a criar um Estado com unidade territorial, igualdade civil, autonomia administrativa, defesa da liberdade religiosa, organização federalista, entre outros, ganhavam espaço no contexto em que as "nações" procuravam uma maior autonomia no quadro internacional, todavia os porta vozes dessa "ideia nacional", quase que inevitavelmente, representava a perspectiva de uma "modernização construída pelo alto". Segundo Eric J. Hobsbawm:

As nações e seus fenômenos associados como o nacionalismo, devem ser analisados em termos das condições econômicas, administrativas, técnicas, políticas e outras exigências; por essa razão são, do meu ponto de vista, fenômenos duais, construídos essencialmente pelo alto, mas que, no entanto, não podem ser compreendidas sem ser analisadas de baixo, ou seja, em temos de suposições, esperanças necessidades, aspirações e interesses das pessoas comuns, as quais não são necessariamente nacionais e menos ainda nacionalistas. (Hobsbawm, 2004: 21).

No que diz respeito aos países periféricos como o Brasil, isto é, na condição de dependente economicamente, o nacionalismo tem a característica de representar a tentativa de maior autonomia do país. Trata-se do intuito de superar o atraso congênito - no caso brasileiro caudatário da época colonial -, que boa parcela dos países com passado colonial enfrentava e cujo "antídoto, mais adequado contra esse mal seria a adoção do ideário nacionalista.” (Rodrigues, 1965).

Muitas vezes o nacionalismo forma uma atmosfera favorável para que os nossos desígnios sejam atendidos. Assim sucedeu nos tempos da Independência, assim está acontecendo nos tempos atuais. Naquela época, tratava-se de conquistar os direitos que a soberania política confere. Na atualidade, trata-se de completar nossa maioridade econômica. Realmente, é mister que passemos da condição de país subdesenvolvido, produzindo sob uma economia complementar de economias industrializadas, para a condição de país dotado de uma infra estrutura econômica e industrial, capaz de nos fornecer os indispensáveis recursos para o aproveitamento de nossas matérias-primas, para o aumento de nossa produtividade, a fim de nos convertermos num grande mercado interno na base da população que já possuímos, a oitava entre os países do mundo. A atmosfera política indispensável e semelhante empresa é a do nacionalismo, porque as tarefas mais urgentes de tamanho empreendimento, as prioridades de sua realização, o ritmo de suas obras, tudo depende primordialmente de nós brasileiros, da urgência por nós sentida na batalha contra o atraso técnico e industrial. (Lima, 1981: 73).

O nacionalismo definido por Hermes Lima é compartilhado por José Honório Rodrigues, pois a sua defesa dos princípios de ação do povo, vislumbrando um governo que tivesse em mente; "primeiro o povo, todo governo deve ser para atender o povo" é prodigioso em esboçar a tematização que permeia as suas argumentações. Seu balizamento crítico é de um nacionalista que, na tentativa de maior dinâmica à 
sociedade, pauta-se pelo reforma política como meta a ser alcançada. Essa premissa é o indicativo que temos na figura do historiador carioca um intelectual que defende o nacionalismo como política de base que "permita incorporar a níveis de produtividade de renda mais satisfatórias a grande massa da população”. (Lima, 1981).

A manifestação do nacionalismo em sua obra foi determinante para a tomada de posicionamento frente às questões mais premente na sociedade, tendo essa se materializado em suas obras após a passagem pela ESG e, principalmente, com os acontecimentos posteriores ao golpe civil militar de 1964. O que podemos destacar em seu legado é a preocupação em interpretar a realidade e os problemas políticos e sociais que atingiam o país, a ideia de "história viva", passa a imperar em seu cotidiano como arguto observador. Segundo o José Honório Rodrigues:

Um governo não é legítimo porque tem à sua frente um Imperador, um marechal ou um almirante; mas porque seu chefe civil ou militar, não usurpou a soberania popular, respeita e obedece à constituição, e é e tem que ser respeitado e obedecido por toda a nação. A situação política atual se caracteriza pela existência de três minorias e uma maioria. (...) Esta maioria, o povo, se compõe de sobreviventes. O problema real é aguentar o ter vivido e enfrentar o não viver. O importante é sobreviver, enfrentar, vencer o dia de hoje para poder novamente durar o amanhã. (Rodrigues, 1970: 8).

O nacionalismo honoriano é caracterizado por uma tentativa de modernização da sociedade brasileira aliado a um dinamismo do ponto de vista político, estando este, por sua vez, relacionado à adoção de princípios do liberalismo político. Em seus argumentos não há nenhuma contradição nessa relação, pois há possibilidade de romper com os interesses que subjugam o povo, no caso o imperialismo norteamericano.

A procura da ideia de Brasil Moderno ${ }^{52}$, de uma explicação plausível para a sociedade brasileira, passa a ser sua meta como intelectual. Nesse sentido, partese, portanto, para a tentativa de representar esse país que precisa "olhar para si"

\footnotetext{
${ }^{52}$ Octávio Ianni foi o intelectual que melhor fundamentou essa procura de teses para o "Brasil Moderno", segundo o sociólogo: "Uma das singularidades da história do Brasil é que este é um país que se pensa continua e periodicamente. Ele se pensa de forma particularmente sistemática, no contexto de conjunturas críticas ou a partir de dilemas e perspectivas que se criam quando ocorrem rupturas históricas. Nessas ocasiões, a sociedade nacional como um todo, ou em alguns dos seus setores sociais mais atingidos pela ruptura, ou mais interessados nela, logo se põem a analisar o curso dos acontecimentos, suas raízes próximas e remotas, suas tendências prováveis no futuro. As interpretações tanto podem priorizar um ou outro setor da sociedade como formular visões de conjunto, integrativas, buscando as linhas mestras da história nacional. Daí a profusão de explicações, interpretações ou teses que multiplicam, sucedem, complementam e polemizam. Sem esquecer que os interpretes tem sido principalmente brasileiros, mas que também muitos são estrangeiros. O fato de que são muitos os estrangeiros que se debruçam sobre dilemas e perspectivas da sociedade brasileira, em geral também procurando traçar as linhas mestras dessa história, pode ser tomado como mais um elemento intrigante.” (Ianni, 2004: 41).
} 
(Rodrigues, 1970: 12), procurar superar todos os obstáculos que impedem o seu desenvolvimento qual seria a melhor forma de alcançar essa empreitada, não aceitarmos a postura dominante, não devemos querer ser "europeus", devemos procurar a criação e uma nova estrutura política e social para o enfrentamento dos problemas mais prementes da sociedade. A tentativa é de constituirmos uma Nação que seja autônoma e independente. Segundo Honório.

Uma forma simplista de identificação não basta - é triste, não é triste, é ou não cordial, é ou não hospitaleiro. A chave não é o índio, nem o negro, pois a mistura dissolveu as culturas. Não é também o português, de quem nos distanciamos dia-a-dia, desde o primeiro dia. Não é a fronteira, nem o sertão, nem o litoral, não é o cangaço, nem o alienado euro-afrancesado; não é o pai de santo nem o fanático, nem a capoeira, nem o coronel; nem o lavrador, nem o senhor de engenho, nem o fazendeiro, comerciante, industrial; não é o medalhão, nem o esnobe, nem o finório, nem o alienado ou caiado - porque é tudo isso e mais algo que se tenta exprimir e que exige pesquisa mais ampla e séria. O que somos veio na Caravela de Colombo, escrevia Machado de Assis em 1876. Ai esta um problema fundamental. Uma forma clássica e ortodoxa consiste em ver-nos como neo-europeus. (grifo nosso). (Rodrigues, 1965: 11).

Uma elite que se disfarça de forma exagerada e perde sua identidade caiada - figura como notória forma de análise de José Honório no tocante a esse espírito de dependência que reina sobre nós. Esse posicionamento, ao nosso entendimento, é fruto dessa vinculação mantida entre os grupos intelectuais que compunham os centros de discussão a respeito do rumo da sociedade brasileira. Durante os anos de ESG, o intelectual carioca formula elementos para concretizar a interpretação da sociedade através de uma ótica nacionalista e a, nesse sentido, produção no que diz respeito às influências sofridas por essa passagem são nítidas se entendermos que o nacionalismo reflete uma dicotomia entre a "própria instituição e seu papel em relação ao Brasil e à condição mundial de Guerra Fria." (Rodrigues, 1965).

A interpretação com respeito a ESG só será modificada após o golpe militar Com a instituição do Regime Militar e o início do período que o historiador carioca denominou de "Generalismo Presidencial", a ESG perde seu caráter democrático, segundo o próprio autor de Conciliação e reforma política:

Em 1964, ainda fui convidado a fazer conferência na ESG, como fazia todos os anos, desde 1956, mas o rumo autoritário, antidemocrático, que assumiu o movimento de 1964, uma contra-revolução, me levou a assinar vários manifestos, quando se pensava que manifesto podia influir no rumo dos acontecimentos. De 1965 até o ano passado não fui mais convidado. O convite em 1977, a que não pude atender em razão de compromissos internacionais, 
revelou-se para mim como uma abertura. A ESG, quando a cursei, ouvia opiniões de todas as correntes, inclusive muita gente com conhecida vinculação esquerdista. (Rodrigues, 1986: 144).

Mesmo com passagem expressiva e de relevo para suas tematizações, a partir do Golpe Militar de 1964 houve um afastamento de José Honório Rodrigues da ESG e uma clara oposição ao regime militar. Para o intelectual carioca, o movimento que caracteriza como "contra-revolucionário" introduzira um regime presidencial “imperial” em que o presidente tinha plenos poderes de um "czar". Além disso, a sucessão presidencial era feita através de sistema indireto e o que determinava a escolha era o "conselho de Estado, composto por membros pertencentes ao mesmo grupo militar dominante" (Rodrigues, 1980: 160). Os generais-presidentes no seu conjunto, quaisquer que sejam as diferenças pessoais de um para outro, possuem características gerais que formam o que se pode chamar "generalismo-presidencial". Segundo José Honório:

O generalismo constitui uma ideologia contra-revolucionária de defesa do status quo, do neocapitalismo brasileiro, antinacionalista, pois defende as multinacionais e a desnacionalização da empresa brasileira. Suas raízes são antiradicais imperiais, absolutistas e colonialistas. Anti-radicais porque significam o contrário do radicalismo nacionalista que vem de 1817 e que João Ribeiro caracterizou como radicalismo mameluco, isto é, mestiço, como a gente brasileira. Absolutistas porque concentram no Poder Executivo todos os poderes, tantos quantos os de que gozava a Monarquia absoluta, anticonstitucional e anti-representativa; colonialista porque tentam colonizar o povo brasileiro, considerando-o um menor, que deve ser tutelado. Não só concentra os poderes, desprezando a velha regra democrática da separação do Poderes, como abusa como quer, sem limites, de seus poderes de força, pois usa o poder militar para satisfação de seus próprios nacionais ou pessoais. (Rodrigues, 1980: 161).

Esse afastamento adotado por José Honório Rodrigues e sua crítica a ESG denota o conteúdo conservador adotado dentro da linha de ação da instituição, que modificou a estrutura de seus cursos e dos participantes civis de seus seminários. Até, então, as divergências existentes dentro de grupos conflitantes não criava um forma de atuação coesa e unitária ${ }^{53}$. Todavia, a partir desse momento existe um distanciamento do

\footnotetext{
${ }^{53}$ No que diz respeito a ESG, Antonio Carlos Peixoto escreve que: "Entre os dois grupos que existiam dentro da ESG, um nacionalista e outro antinacionalista, a corrente nacionalista desenvolvia sua ação política visando a provocar uma mobilização da opinião pública, o núcleo controlador da ESG procurava reforçar suas posições dentro da máquina do Estado, por meio de alguns estudos via de regra envolvidos em grande segredo e restritos a pequenos grupos. A estratégia de desenvolvimento nacional criada pela ESG dava destaque à mobilização das elites, a partir de esquemas teóricos que integravam a Doutrina de Segurança Nacional. O conceito de Segurança Nacional não possuía o mesmo sentido para as duas correntes que se defrontavam. Para os nacionalistas, a segurança residia, antes de qualquer coisa, na possibilidade de um desenvolvimento nacional afastado dos grandes centros de decisão do capitalismo
} 
intelectual carioca que voltaria a participar da instituição como conferencista a partir do cenário da abertura política.

Cabe destacar que o movimento de 1964 teve na ESG a instituição que mediou às condições ideológicas instituídas pelo contexto da Guerra Fria, além de levar em consideração ao modo de desenvolvimento do capitalismo brasileiro. Segundo Rene Dreifuss:

A ESG incorporou em solo brasileiro as ideias e as atitudes maniqueístas dominantes no cenário internacional da Guerra Fria. Como uma instituição, a ESG encorajou dentro das Forças Armadas normas de desenvolvimento associado e valores empresariais, ou seja, um crescimento cujo curso industrial foi traçado por multinacionais e um Estado guiado por razões técnicas e não "políticas". Este Estado seria estável por intermédio do autoritarismo político incorporado na doutrina de segurança nacional. Ideologias americanas de "construção nacional" foram disseminadas entre as Forças Armadas Brasileiras e reforçadas pela doutrina empresarial. (Dreifuss, 1986: 79).

O movimento de 1964 expõe o país à ação dos militares de forma mais contrária aos interesses do povo, é um governo de caráter antinacional que retoma medidas do colonialismo, pois em sua fase pós golpe ele é representado pelas elites que vêem o povo como um conjunto de incapazes que merecem ser tutelados. O resultado dessa prática e amplamente arbitrário, pois existe um antagonismo entre a soberania nacional que pertence ao povo e as prerrogativas imperiais, ou seja, dos generais presidentes. Há uma usurpação da soberania popular pela soberania dos generaispresidentes, que "não sendo de direito divino são de direito da força." (Rodrigues, 1982: 162). E a força é tão grande que eles nomeiam seus príncipes herdeiros, que não são, como nos regimes monárquicos, "preparados desde o nascimento para a função." (Rodrigues, 1982).

O uso da força pelo Poder Executivo, que a entende como o elemento determinante de seu controle sobre os setores subalternos, reprimindo seus mais legítimos e autênticos interesses, esse é um momento, que na análise de José Honório Rodrigues, mais uma vez o liberalismo político torna-se incompatível dada a violência e o autoritarismo do regime militar. Esse seria o "verdadeiro imperialismo que assolara o povo brasileiro" (Rodrigues, 1965). A respeito do assunto afirma Honório:

internacional e sustentado por rigorosa mobilização popular. Para os antinacionalistas, grupados em torno da ESG, a segurança nacional possuía implicações diferentes. Seu ponto de partida era dado pela divisão irremediável do mundo em dois blocos hostis, isso forçava o Brasil a buscar suas alianças no bloco ocidental. $\mathrm{O}$ mundo conhecia tensões que transpunham as fronteiras nacionais. A segurança nacional devia levar em conta esse inimigo interno que se manifestava através da guerra revolucionária. Para enfrentar esse gênero de ameaças, a mobilização e a coesão das elites eram indispensáveis. (Peixoto, 1980: 87). 
E o que é o generalismo presidencial, senão o imperialismo dos generais, o abuso dos militares, o predomínio da força sobre o direito, a tutela sobre o povo, o desapreço às liberdades públicas e individuais, e a recolonização do povo, cujo consenso se despreza como despreparado, quando não há, na história do Brasil, na continuidade do seu processo, nenhuma vitória brasileira ganha senão com o povo, com seu inteiro apoio. Não é possível anteporem ao país um homem e a tirania à liberdade. A liberdade não é uma inimiga do país, a força sim, e esta não viola impunemente o país, nem a nação se personifica nos lisonjeiros do poder que a escandalizam. Um exército disciplinado, que simboliza a força nacional, está a serviço da nação e de seu povo, e não de personagens que aterrorizam a nação. (Rodrigues, 1982: 163).

O papel do exército foge de seu verdadeiro intuito dentro de uma sociedade composta por instituições liberais. A defesa dos limites territoriais e sua composição como organização que visa defender a sociedade, nesse caso, não cumpre com sua função. As indicações que faz ao longo do texto remetem a uma avaliação das mais nefastas a respeito do período vivido a partir de abril de $1964^{54}$. A combinação de medidas que aterrorizam o povo e, cada vez mais, instituiu um regime francamente antidemocrático levou o intelectual a posicionar-se nitidamente, sobretudo devido ao clima de insatisfação que o acomete. $\mathrm{O}$ antinacionalismo, explicitado pelas lideranças do governo autoritário, tem respaldo dos responsáveis pelo generalismo, pois esses desconhecem os direitos do trabalhador nacional, "que desde o período colonial foi o grande responsável pela construção do país.” (Rodrigues, 1982: 168).

A instituição do governo civil militar e todo o seu caráter "antipovo" afeta diretamente a possibilidade de qualquer reflexão mais apurada dentro da instituição, tendo como resultado, na postura de José Honório, o seu distanciamento da ESG e a ideia de pensar a sociedade brasileira a partir de sua necessidade atual, clamando a "História viva" para dar conta de uma nova demanda, por mais que esta esteja calcada numa postura nacionalista, ou seja, a tentativa de fazer uso do "presentismo", a partir do aprendizado que teve com a leitura de Benedeto Croce ${ }^{55}$. A ardente militância nacionalista colocava de forma emergencial a compreensão do governo arbitrário, o que acabou resultando na crítica honoriana ao "generalismo presencial". Esse contexto teve como resultado para a ação e reflexão honoriana, a

\footnotetext{
${ }^{54}$ A respeito da ideologia de segurança nacional que foi tema de amplo debate, principalmente após o golpe civil militar de 1964, ver: Comblin (1980).

55 Antonio Gramsci, em estudo sobre a "filosofia de Benedeto Croce" e sua concepção política e historiográfica, argumenta que: "De fato, somente uma filosofia ultra-especulativa, como é o caso do atualismo, as contradições e insuficiências da filosofia crociana encontram uma composição formal e verbal; mas, ao mesmo tempo, o atualismo demonstra, de maneira mais evidente, o caráter pouco concreto da filosofia de Croce, da mesma forma como o "solipsismo" documenta a íntima debilidade da concepção subjetiva-especulativa da realidade." (Gramsci, 2004: 294).
} 
produção no campo da Política Externa e na crítica desferida a postura adotada pelos militares a partir de 1964, momento em que seu ideário nacionalista-liberal foi assumido e acabou levando o intelectual para o campo de ação, ou seja, o intelectual foi para a trincheira. 


\section{II - Conciliação e conciliadores: a História Cruenta na formação da sociedade brasileira}

A base da argumentação de José Honório encontra-se em seus dois livros; Aspirações Nacionais $(1963)^{56}$ e Conciliação e Reforma Política (1965). Nas obras mencionadas encontra-se uma postura que visa a análise da realidade social e política do país. O conhecimento adquirido como grande teórico da história passa a analisar a identificar no passado elementos explicativos para o melhor entendimento do presente. Neste sentido, ao longo deste capitulo, pretendemos discorrer a respeito dessa base interpretativa de José Honório, ou seja, a proposta heurística que surge nessas duas obras: "conciliação" e o "conciliador", como conceituação fundamental para o entendimento político e social do Brasil e a "História cruenta", como particularidade da dinâmica do liberalismo brasileiro.

Ambos os conceitos são, ao nosso entendimento, de fundamental importância na obra honoriana para a elucidação da interpretação do Brasil que o intelectual carioca nos ofereceu. Todavia, acreditamos que o eixo central de tais argumentações ainda discorre sobre o nacionalismo liberal que marcou de forma indelével o legado do autor.

Em 1978 houve um debate a respeito do livro recém lançado de José Honório Rodrigues, História da História do Brasil. Questionado se a obra poderia ser inserida no "projeto nacionalista" sobre o qual o autor se lançar a partir dos anos 50, sua resposta foi contundente:

Minha viragem para os problemas do presente, para fazer com que a história fique ligada, tente responder às indagações presentes, resulta de duas coisas: primeiro de certas influências de caráter filosófico, e da problemática nacional que se vai agravando; e da minha entrada para a Escola Superior de Guerra. Em 1955, quando entro na ESG, deparo com aquela problemática nacional toda, pois a escola nessa época era muito aberta, ouvia todas as tendências, e eu vivia até então num ambiente fechado, muito erudito. Senti que o historiador tinha que estar mais atualizado com o seu presente para que realmente pudesse buscar no passado aquilo que respondesse as interrogações do presente. (Rodrigues, 1986: 151).

Dessa forma, José Honório Rodrigues apresentava as motivações que levaram à inflexão em sua produção intelectual. O historiador responsável por

\footnotetext{
${ }^{56}$ Sendo 1963 a data de sua primeira publicação, iremos utilizar a edição de 1970.
} 
expressiva produção em Teoria e Metodologia da História abre espaço para o intelectual que procura estabelecer um diálogo com os problemas e a complexidade da sociedade brasileira a partir do final dos anos de 1950, dessa são as obras Aspirações Nacionais (1963) e Conciliação e Reforma Política (1965), o ponto desta inflexão. Nos livros mencionados o intuito é a intervenção que procura denunciar os problemas que se perpetuam na sociedade e limitam as aspirações e necessidades mais prementes do povo brasileiro. Uma produção que objetiva, de forma imediata, interferir nos debates que o momento impunha. As obras mencionadas vislumbram um "roteiro interpretativo" da sociedade brasileira, pois o autor explícita as condições em que a "conciliação" foi sempre uma prática que pouco atendeu as aspirações da nação.

Neste capítulo, iremos apontar quais foram os artífices da política brasileira que em suas práticas foram conciliadores com o povo, como esses expressavam o movimento do liberalismo político em suas ações, além disso, pretendemos resgatar a conceituação de José Honório a respeito da história cruenta. Ao nosso entendimento, a relação entre história cruenta ou incruenta foi utilizada para explícitar o resultado de uma política conciliatória sem que houvesse qualquer melhoria na vida da maior parte da população. As tentativas de manifestação de descontentamento dos setores subalternos resultaram em medidas de violência por parte das lideranças "tradicionais" que tinham aversão em sucumbir as "legítimas aspirações do povo brasileiro". Nesse sentido, Honório procura identificar nos conciliadores existentes ao longo da História do Brasil, aqueles que propunham um projeto de EstadoNação que contemplasse as necessidades básicas e imediatas de uma boa parcela do país.

O Brasil pode ser visto como um país, uma sociedade nacional, uma nação ou um Estado-Nação, em busca de conceito. A despeito de que tem nome e história, território e fronteiras, bandeira e hino, população e governo, heróis e santos, memórias e esquecimentos, glórias e sofrimentos, ruínas e monumentos, debate-se contínua e periodicamente no sentido de conhecer-se, definir-se, estabelecer o seu lugar no mapa do mundo: Europa, África ou Novo Mundo, branco, mestiço, indígena ou negro; arcaico ou moderno; autêntico ou errático; pretérito ou futuro; do terceiro mundo ou a caminho do primeiro mundo; cujo nome pode ser o de um país, vegetal ou mercadoria. (...) Esse é o estado de espírito ou mentalidade que permeia as muitas inquietações de uns e outros, levando-os a buscar a fisionomia, o modo de ser, a realidade, os dilemas e as perspectivas da sociedade brasileira, do povo brasileiro, do Brasil como EstadoNação. São muitos os que se questionam qual pode ser a sua fisionomia, a sua explicação ou o seu conceito. Perguntam-se sobre qual pode ser o "Norte", ou a direção, já que se repetem os impasses, as reorientações, os progressos e os retrocessos. (Ianni, 2004: 67). 
A história do Brasil tornou-se cruenta quando houve manifestações por parte de setores subalternos que questionaram toda a forma de liderança tradicionalista. E ao mesmo tempo enxergam o poder como prática de atendimento centrada nos interesses de seus próprios representantes; isto é, entre aqueles que conciliavam-se somente entre seus pares. Outro aspecto que José Honório procura denunciar e que mesmo nos momentos de violência - História Cruenta - existiram intelectuais que tentaram minimizar essa forma de ação da elite. São esses os responsáveis por uma tradição do pensamento conservador no Brasil.

Por isso procuramos analisar a obra de um intelectual que teve como meta oferecer subsídios para melhor compreendermos o Brasil. Cabe destacar que para tanto foi fundamental a contribuição de Quentin Skinner $^{57}$ no que diz respeito às conceituações e formas de análise da história do pensamento social e político. Nessa perspectiva levamos em consideração que a produção honoriana está ligada a certa concepção da realidade, sua análise pauta-se em determinado "chão social" e esse tem nexos com a realidade. A formulação goldmanniana de "visão social do mundo" "58, ao nosso entendimento, fora utilizada para conseguirmos, até o possível, manter esse vinculo de sua produção com as representações e ilações como intelectual, com o os grupos e classes sociais que trava um diálogo velado ou revelado.

\footnotetext{
57 Segundo Quentin Skinner: “(...) Começo discutindo o que considero ser as características mais relevantes das sociedades nas quais e para as quais eles originalmente escreveram. Pois entendo que a própria vida política coloca os principais problemas para o teórico da política, fazendo que um certo elenco de pontos pareça problemático, e um rol correspondente de questões se converta nos principais tópicos em discussão. Isso é uma consequência direta de sua base social. Considero igualmente essencial levar em consideração o contexto intelectual em que foram concebidos os principais textos - contexto das obras anteriores e dos axiomas herdados a propósito da sociedade política, bem como o contexto das contribuições mais efêmeras da mesma época ao pensamento social e político. Pois é evidente que a natureza e os limites do vocabulário normativo disponível em qualquer época dada também a contribuição para determinar as vias pelas quais certas questões em particular virão a ser identificadas e discutidas. (...) Se conseguirmos cercar esses clássicos com o seu contexto ideológico adequado, poderemos ter condições de construir uma imagem mais realista de como o pensamento político, em todas as suas formas, efetivamente procedeu no passado. Um mérito que assim me atrevo a apontar no método que descrevi é que, se for praticado com sucesso, poderá começar a dar-nos uma história da teoria política de caráter genuinamente histórico.” (Skinner: 1996: 11).

${ }^{58}$ Michel Lowy tece os seguintes comentários a respeito: “(...) Queremos insistir em dois aspectos para a compreensão da "visão social de mundo": trata-se da visão social do mundo, isto é, de um conjunto relativamente coerente de ideias sobre o homem, a sociedade, a história, e sua relação com a natureza e esta visão de mundo está ligada a certas posições sociais, isto é, aos interesses e á situação de certos grupos e classes sociais. (...) As visões de mundo podem ser ideologias ou utopias. Elas podem combinar elementos ideológicos ou utópicos: por exemplo, a filosofia do Iluminismo. Além do mais, uma mesma visão de mundo pode ser concebida de modo ideológico ou utópico. Enfim, a mesma visão de mundo pode ter um caráter utópico num dado momento histórico, para tornar-se, em seguida, numa etapa ulterior, uma ideologia. (Lowy, 2003: 13).
} 


\section{1 - Limites da conciliação: $O$ tradicionalismo da elite dirigente}

Se recuperarmos o processo de formação da sociedade brasileira e identificarmos como marco histórico plausível de análise, o período originário da história brasileira a chegada dos portugueses, o primeiro contato dos europeus com a civilização nativa, a relação de escambo entre outros, perceberemos que já ali existia a prática conciliatória. Caramuru - Diogo Álvares - era o responsável pela seguinte façanha; conciliador que não era hostil e violento à população nativa, muito menos tomava qualquer medida contrária aos interesses da Coroa Portuguesa, pois "vivia bem entre portugueses e indígenas”. (Rodrigues, 1965: 24) Começava assim a prática conciliatória, uma forma de manutenção dos pressupostos institucionais da política ao longo da história. Uma defesa do status quo encabeçada pelos conciliadores que não se aventuravam em agir de forma a defender os interesses da maioria do povo brasileiro, a procura com seus atos é colocar em prática uma forma de aproximação ou elo, mesmo que de forma arbitrária, entre os dois pólos antagônicos na sociedade.

A política de conciliação mostra o quanto o espírito anti-reformista dominou nossa história e a conciliação formal, partidária, visava a romper o círculo de ferro do Poder, para as facções divergentes, os dissidentes, pudessem dele fazer parte. Quando o acordo, feito sempre sem nenhum benefício nacional e popular, demorava muito, os dissidentes indignavam-se e conspiravam. Foi esse o papel dos liberais na história brasileira. Derrotados nas urnas e afastados do Poder, eles foram se tornando, além de indignados, intolerantes, e construíram uma concepção conspiratória da História, que considerava indispensável a intervenção do ódio, da intriga, da impiedade, do ressentimento, da intolerância, da intransigência, da indignação para o sucesso inesperado e imprevisto, tal como sucedeu em várias partes, de suas forças minoritárias. (Rodrigues, 1965: $11)$.

A ação derivada da liderança política não colocava em conflito os interesses ligados ao grupo que compunha a elite nacional. Seu supremo poder colidia contra qualquer grupo ou facção que elaborasse algum projeto questionador à ordem. A "conspiração" do ponto de vista teórico era o instrumento manipulador usado nesses momentos. José Honório desenvolve seus argumentos apontando os limites dessa conciliação quanto ao modo de controle e direção do Estado brasileiro. Segundo o autor, 
impera no Brasil um tradicionalismo que ganha força e encastela-se no poder político, fazendo uso desse e, "a ferro e fogo" mantendo o cenário político social sem nenhuma alteração. A política de conciliação ${ }^{59}$ foi quase sempre uma mistificação e serviu para "tapear o curso da história".

A prosa honoriana contém os subterfúgios criados para que a sociedade não apresentasse condições de mudança. As ondulações quase não existem, para exemplificar essa situação devemos entender que no Brasil há uma "estabilidade granítica" que se perpetua. Entretanto, o que melhor caracteriza esse continuísmo, para o historiador carioca, é o tradicionalismo:

As forças de resistência à mudança no Brasil são tradicionais e nelas se destacam a resistência jurídica e parlamentar, expressões intelectuais da estrutura econômico-social arcaica. (...) A produção intelectual não deve falar em nome da Tradição, mas da Verdade. Uma produção intelectual in statu pupilari pode ter como missão engrandecer as elites e enfraquecer o povo. Pois é com ele, com suas virtudes e seus erros, que temos de contar para fabricar o destino brasileiro. (Rodrigues, 1965: 13).

O povo brasileiro que sempre foi oprimido pelas elites, nunca encontrou um momento da história em que seu papel foi destacado, a prática, quase como regra, é apequená-lo. O intelectual carioca procurou identificar momentos em que a conciliação fora prática das elites, que não permitia maior ação dos setores subalternos e tomava de lance as aspirações daqueles e impunham pequenas e pontuais mudanças na sociedade como se fossem avanços expressivos ${ }^{60}$. As coalizões, os antagonismos, entre as forças

\footnotetext{
${ }^{59}$ Ex-aluno de José Honório Rodrigues e importante historiador, Alberto Cosa e Silva argumenta que: "Entre os que foram-se tornando povo brasileiro - os índios convertidos e os selvagens, os negros escravos, libertos africanos e crioulos, os brancos reinóis e os mazombos, os mamelucos, os mulatos e os cafuzos, tão diversos entre si, tantas vezes conflitantes e na aparência irredutíveis -, venceram os conciliadores sobre a violência dos intransigentes, num processo a que não faltaram pelourinhos, quilombos, motins, revoltas, repressões sangrentas, fuzilamentos, enforcamentos, esquartejamentos, guerras e mais guerras, mas no qual, se foi importante, nos momentos em que prevaleceu, o papel das elites conciliadoras, muito mais decisivo foi o das maiorias que se miscigenavam os indígenas vencidos, os negros cativos, os mestiços de todas as cores. A essa conciliação efetuada no seio do povo devemos ter o Brasil, desde cedo, deixado de ser "uma caricatura de Portugal" nos trópicos, e possuir um substrato novo, "apesar do europeísmo e lusitanismo e dominante na aparência das formas sociais". (Costa e Silva, 1999: 384).

${ }^{60}$ Ainda segundo Alberto Costa e Silva: “A conciliação pela inércia sempre empurrou para o futuro os grandes problemas nacionais. Só há os enfrentamentos, temerosos e prudentes, quando não há mais jeito de evitá-los. Com grande atraso, portanto, e, em geral, com soluções e remédios que já perderam a eficácia. Não se busca a concórdia pelo respeito à diversidade das ideias e pela aceitação de que governe um partido e de outros discordem. O que se procura é diluir ou, se possível, anular o dissenso. Por isso, perdoam-se e reabsorvem-se os revoltosos, sempre que esses são tidos por iguais, como os dos Farrapos,
} 
renovadoras, que defendiam um sistema político com mais integração da sociedade, e as lideranças arcaicas, que defendiam os meios mais anti-povo, foram sempre o aspecto político dominante no Brasil e daí as monstruosidades sociais e educacionais que presenciamos.

Esta forma tão violenta e pouco integradora, que tinha como meta primordial satisfazer as necessidades da estrutura econômica portuguesa em pleno desenvolvimento e o tradicionalismo da elite portuguesa, eram os obstáculos a serem superados pelos conciliadores. O tradicionalismo foi impregnado para justificar a forma de ação estagnada, antiga, sem nenhum vínculo com um traço possível de ampliação das peculiaridades de uma nova ação social. Ele era compreendido como a reação original a deliberadas tendências reformistas, que no seu projeto originário apontavam para mudanças estruturais na sociedade.

Para esboçar o que representa uma aristocracia tradicional, basta identificarmos o quanto ela manteve sempre o poder final de veto e, assim, nunca permitindo que as mudanças radicais fossem colocadas em prática, como as produzidas pelas reformas ou revoluções sociais. Honório explica que:

Se a violência não é o elemento histórico fundamental da vida brasileira, como o foi em outras partes, se as aspirações de tolerância predominavam, se a mestiçagem abrandou as relações sociais, a verdade é que nunca tivemos uma Revolução. O terror e a força foram utilizadas no começo para manter submissos índios e negros e mais tarde para manter oprimido o povo ou derrotar suas aspirações. (Rodrigues, 1965: 103).

Os representantes do tradicionalismo, sempre tendo como expoentes os integrantes desta aristocracia agrária arcaica, colocaram-se contrários a qualquer avanço da sociedade brasileira. Exemplo disso é o contexto pós independência que, ao invés de criar um Estado autônomo, acabou reproduzindo todo o sistema político da Metrópole. Como argumenta o intelectual carioca:

O Brasil foi o único país do Novo Mundo que fez a Independência com a instituição de um regime monárquico, idêntico ao da Metrópole. Não se recorreu a dinastia estrangeira, e a emancipação política assumiu a aparência de um desenvolvimento natural, frenando as tendências à anarquia civil, e contribuindo para conservar intacto o patrimônio territorial da América cabanos ou, já na república, os beatos de Canudos.” (Costa e Silva, 1999: 386). 
Portuguesa. A consequência imediata da unidade foi o gigantismo dos problemas e das tarefas, desafio que, desde a Independência, tiveram de enfrentar as minorias dirigentes. Gigantismo acrescido de várias dificuldades, para uma população precocemente dispersada e que, no exclusivismo colonial e no isolamento nacional, só fez regredir, tornando-se insuficiente, econômica e espiritualmente. Revelava também, essa sua primeira ação política, uma capacidade muito plástica de acomodamento político, que se prende a contemporização e à capacidade de adaptação. A solução era facilitada pela própria reconstituição da sociedade patriarcal, dividida em duas castas, a dos senhores e a dos escravos. (Rodrigues, 1970: 56).

O historiador carioca explica como as forças presas a um passado impediam a sociedade brasileira de ampliar sua organização social em sentido mais amplo, ou seja, pudesse atender as aspirações de um maior número de integrantes.

As colisões e antagonismos entre forças renovadoras e a liderança arcaica foram sempre o aspecto político dominante no Brasil e daí as monstruosidades sociais e educacionais que presenciamos. O processo histórico brasileiro tem sido dirigido por espectros num organismo vivo, que é o povo, responsável maior pelas maiores conquistas, a unidade lingüística e política, a expansão e integridade territoriais, a homogeneidade cultural, a tolerância racial e religiosa. (...) Nenhuma reforma foi completa e a própria Abolição não se concluiu com a reforma agrária, embora o retardamento tivesse impedido na abolição da escravatura a indenização dos proprietários. Os remendos dos fósseis são culpados da ressurreição dos problemas. Por isso gerações sucessivas, jovens e velhos, ouvem sempre falar no "Brasil a beira do abismo". (Rodrigues, 1965: $18)$.

A interpretação de nosso atraso, do processo letárgico que impede as grandes reformas fica por conta da ação de uma elite pequena que não vislumbra qualquer possibilidade de mudança nos rumos sociais e políticos que o país toma. Nesse sentido, seria necessário encontrarmos lideranças razoavelmente capazes de implementar tais reformas. Explica Honório:

O processo histórico brasileiro compõe-se mais de instantes de retardamento que de instantes de aceleração e a liderança tem sido mais dominadora que criadora. A metamorfose pode ainda demorar, embora o prazo histórico esteja se esgotando. (...) Da luta entre uma facção composta de condutores cegos e outra 
que prefere conduzir uma caminhada reformista depende o destino do desenvolvimento do processo histórico no Brasil. A primeira é apenas dominadora, a outra é criadora. A revolução deve ser a vitória do contemporâneo e não a sobrevivência do arcaico. (Rodrigues, 1965: 19).

Os retardamentos e a impossibilidade de modernização são as características marcantes da elite agrária no controle do Estado, sua ação, segundo José Honório, "assolada no tradicionalismo" (Rodrigues, 1970) impede esse movimento em busca de aspectos reformadores do país. O grande obstáculo, sem dúvida, é a condição típica dessa liderança, que não contempla os setores subalternos e muito menos "reforma a sociedade brasileira".(Rodrigues, 1965: 21).

A respeito da conceituação desse tradicionalismo recorrente na ação das lideranças políticas, a tematização que o sociólogo Karl Mannheim apresenta é bem elucidativa $^{61}$. O tradicionalismo, como forma de expressão de certos intelectuais, dentro de um contexto de específico movimento social, representa uma forma de avaliação social em que a princípio é contrário ao movimento derivado da razão. $\mathrm{O}$ "aspecto mágico", segundo Mannheim, é uma das bases teóricas que explica o tradicionalismo. O princípio de atuação no campo político expressa um liberalismo que era entendido como o direito do indivíduo agir como desejasse e achasse adequado e, especialmente, como o direito ao exercício irrestrito e inalienável dos "direitos dos homens."

De acordo com esses princípios e conceitos de direitos dos homens, é somente ao transgredir os direitos de seus concidadãos a liberdade de um homem sofre qualquer restrição. A igualdade é o corolário lógico desse tipo de liberdade sem a suposição de igualdade política para todos os homens, ela é destituída de sentido. Na realidade, contudo, o liberalismo nunca pensou a igualdade como algo mais que um postulado. Ele certamente nunca a considerou como uma

\footnotetext{
${ }^{61}$ Menção seja feita a análise que o sociólogo inglês Anthony Giddens teceu sobre o assunto: “... a tradição é uma orientação para o passado, de tal forma que o passado tem uma pesada influência, ou, mais precisamente, é constituído para ter uma pesada influência sobre o presente. Mas evidentemente, em certo sentido e em qualquer medida, a tradição também diz respeito ao futuro, pois as práticas estabelecidas são utilizadas como uma maneira de organizar o futuro. O futuro é modelado sem que se tenha a necessidade de esculpi-lo como um território separado. A repetição, de uma maneira que precisa ser examinada, chega a fazer o futuro voltar ao passado, enquanto também aproxima o passado para reconstruir o futuro." (1997: 80). Outro argumento que nos parece pertinente a respeito do tema é o de Eric J. Hobsbawm: “(...) Por tradição inventada entende-se o conjunto de práticas, normalmente reguladas por regras tácita ou abertamente aceitas; tais práticas, de natureza ritual ou simbólica, visam inculcar certos valores e normas de comportamento através da repetição, o que implica, automaticamente, uma continuidade em relação ao passado. Aliás, sempre que possível, tenta-se estabelecer continuidade com um passado histórico apropriado. (1997: 9).
} 
questão de fato empírica e, na verdade, nunca exigiu a igualdade na prática para todos os homens, exceto no curso de disputas econômicas e políticas. No entanto, o pensamento conservador deturpou esse postulado em uma declaração de fato, fazendo parecer que os liberais estivessem pretendendo que todos os homens eram, de fato e sob todos os aspectos, iguais. (Mannheim, 1982: 121).

A condição de manter o tradicionalismo na sociedade, controlando a esfera política antes da constituição de um sistema político razoavelmente organizado, é a base da ação política tradicional. Em oposição à ação conservadora, sempre está associada a "um conjunto de circunstâncias concretas." (Mannheim, 1982). No Brasil, esse tradicionalismo fez com que a lógica da organização partidária, para usarmos um exemplo que ocorre durante quase todo o período imperial, fosse "naturalizada" e sua reprodução mantida como uma necessidade da "Nação" brasileira. Segundo o intelectual carioca:

A política nacional exercida pelos dois partidos e suas combinações transitórias foi sempre anti-reformista. Preferiu conciliar para não reformar. Unindo todos os interessados na defesa do status quo e dos privilégios, evitam-se as ameaças radicais e populares, que puseram em perigo a estabilidade institucional, especialmente entre 1831 e 1840 . A conciliação e as ligas visam a defender a ordem e a estabilidade, nas estranhas combinações entre conservadores e liberais moderados. Com isto excluíram-se os radicais, os exaltados, que aspiravam às reformas de estrutura. (...) Deste ponto de vista, nada foi feito no Império. Antiprogressistas - pois sabiam que progredir era reformar, os políticos imperiais eram desvinculados da realidade nacional e queriam que o povo fosse o que não era. Mas nada ou muito pouco fizeram para transformá-lo, educá-lo, beneficiá-lo sanitariamente. O povo era um fantasma. Antinacionais pela desvinculação, Antiprogressistas pelo anti-reformismo, liberal e conservador não foram imunes a alienação, sem notar a singularidade do país que dirigiam. Doutrinas políticas, estilos parlamentares, instituições, projetos de lei tudo seguia modelos europeus. (Rodrigues, 1965).

Esse modelo organizativo da política nacional representava, para a análise honoriana, os acordos, as relações desprezíveis que os setores que compunham a liderança durante o período do Império articulavam em troca da perpetuação de seus interesses. Mesmo a composição de dois grupos políticos, que ao longo do período 
imperial não apresentavam divergências que fossem consistentes, ou mesmo, que tivessem propostas antagônicas que pudessem levar adiante um projeto alternativo e integrador para a sociedade brasileira, naquele cenário não existia uma expressiva diferença seja Luzia ou Saquarema. ${ }^{62}$ Além disso, a presença de práticas retrógradas e conservadoras sempre foram praticadas, nesse aspecto não diferenciando o tipo de liderança encarregada de controlar o Estado, a lógica era invariavelmente a mesma.

O tradicionalismo, o irrealismo, o personalismo e a corrupção são defeitos da minoria e deles resultam as insuficiências populares. A arte de furtar é nobre e antiga, praticada pelas minorias e não pelo povo. O povo não rouba, é roubado. Os antinacionais e os caiados enfileiram-se na minoria, mas os segundos nascem do povo. Sempre se desrespeitou o princípio de que os grandes momentos criadores da nossa história - e não constituem exceção na história universal - resultam da colaboração íntima e estreita entre a liderança e povo. Cria-se uma tendência que só a liderança cruenta tem o monopólio do poder político. (Rodrigues, 1964: 120).

Esse aperfeiçoamento de determinadas tendências nada mais é que o resultado de um aprimoramento societário que levou inexoravelmente a compartimentações no campo reflexivo, à medida que exista a superação de uma ordem anterior, no caso do Brasil a estrutura colonial sem uma vida dinâmica que amplie as relações de capital, é inevitável que novas concepções sociais e intelectuais se consolidem. Essa particularidade, no que diz respeito a desenvolvimento das condições de identificação de um liberalismo político, ficou impossibilitada, mesmo o liberalismo econômico ficou limitado às restrições do Estado brasileiro ${ }^{63}$.

Nesse sentido, a "consciência limite" que procura uma maior dinâmica e modernização do Estado, em que a meta é o; "Estabelecimento da unidade nacional, a participação do povo no governo do país, a incorporação do Estado na ordem econômica mundial e a solução das questões sociais." (Mannheim, 1982). No caso

\footnotetext{
${ }^{62}$ Segundo o professor Ilmar R. de Mattos: "Era comum ouvir-se dizer, em meados do século passado, não haver nada tão parecido com um saquarema que um Luzia no poder. (...) O provérbio imperial chegou até nós. Não raro, políticos, homens de Estado, historiadores e demais cientistas sociais evocamse para caracterizar, com base em uma ótica negativa, os partidos políticos no Brasil. (Matos, 2004: 115)

${ }^{63}$ Segundo Florestan Fernandes: "O liberalismo adquire a qualidade e a continuidade de força política permanente, embora sua influência tópica fosse variável, por depender da constituição, do funcionamento e da evolução da sociedade civil. Doutro lado, esse fato também explica como as formas de poder político, criadas através da implantação de um Estado nacional, foram assimiladas pelos estamentos senhoriais e convertidas, desse modo, em dominação estamental propriamente dita." (Fernandes, 2006: 59)
} 
brasileiro não figura como uma proposta que esteja entre as principais metas daqueles que controlam o Estado brasileiro, entre outros motivos, porque entre nós, não ocorre o advento do povo no cenário político e social.

A relação entre sociedade e poder, a ponto de existir certa tendência de todas as divisões dentro dela para se desenvolverem em estreita relação com as tensões que surgem durante as tentativas de solução de problemas fundamentais da estrutura social. Nesse sentido, é fundamental o entendimento desta tendência de generalização e consolidação do pensamento tradicionalista, principalmente devido ao "caráter dinâmico do mundo moderno e esta dinâmica estando pautada pela diferenciação social, sendo a responsável em arrastar consigo o intelecto humano". (Mannheim, 1982: 115).

Dessa forma nos parece correto, seguindo as prerrogativas de Mannheim, que o contexto sociológico em que o pensamento tradicionalista ganha espaço é o cenário em que conflito de classes começa a ganhar maior repercussão. Florestan Fernandes, em perspicaz análise a respeito das "Implicações socioeconômicas da independência", explica como a ideologia liberal foi utilizada, não para o desenvolvimento de um "mercado livre", mas sim para atender os interesses senhorias em relação à "tutela colonial". A esse respeito argumenta que:

Contudo, concretizada a independência e garantida a estabilidade no novo regime político, ela - ideologia liberal - se anula como polarização dinâmica específica dos interesses senhoriais (em consequência do desaparecimento das tensões provocadas pela "tutela colonial"), mas ganha força e importância crescentes como polarização dinâmica específicas dos interesses de integração nacional (em consequência das conexões da ordem legal constituída com o princípio da representação e da democratização do poder político no nível dos estamentos dominantes). (Fernandes, 2006: 58).

Acreditamos que José Honório Rodrigues, em sua defesa das legítimas aspirações e interesses do povo, procura identificar como determinados atores do cenário político e social brasileiro tentaram realizar, no limite de suas possibilidades de ação, um projeto de conciliação com o povo ${ }^{64}$. Esse seria o mecanismo mais coerente,

\footnotetext{
${ }^{64} \mathrm{O}$ professor Michel Debrun também foi responsável por sugestivas argumentações a respeito da Conciliação, mencionando que: "Num primeiro nível a conciliação, no Brasil, representou um compromisso entre valores oriundos de horizontes diversos: de um lado, os ligados à herança européia instituídos, sobretudo por padrões religiosos, éticos, estéticos, econômicos ou administrativos; e de outro lado, os que traduzem a influência índia ou africana, consubstanciada em padrões religiosos, éticos ou estéticos, mas muito menos em aspectos econômicos e administrativos." (Debrun, 1983: 14).
} 
pois possibilitaria a tentativa de uma ação política que dinamizasse e modernizasse o Estado Brasileiro, além disso, teríamos a possibilidade de ruptura com o conservantismo das lideranças oligárquicas que foram responsáveis por uma má administração do Estado, não oferecendo ao povo a possibilidade de ter seus interesses atendidos, o que resultou nas tentativas de organização dos movimentos que expressassem seus interesses, pois historicamente esse povo vivia de forma constante "capado e sangrado".

\section{2 - A conciliação de José Bonifácio: projeto de modernização para o Brasil}

A particularidade do capitalismo em nossas terras, que acabou impondo à "organização do capital uma forma incompleta ou mesmo imperfeita", pode ser identificada com a manutenção do trabalho escravo, não tendo o trabalho livre ganho espaço para seu implemento e consolidação. Dessa forma, a constituição de um sistema tipicamente liberal, que atendesse a nova demanda da sociedade recém emancipada politicamente, não conseguia se confirmar em toda sua plenitude, principalmente no que diz respeito ao caráter econômico da ordem liberal. Nas condições de um Estado em que o sistema econômico-político não abandona de forma concreta a ordem anterior, José Honório passa a centrar seus estudos no regime monárquico, tendo em vista nossa possibilidade de desenvolvimento societário e, como consequência, a realização de uma democracia-federalista, com a participação de lideranças políticas que “... se conciliassem com o povo capado e sangrado de nossa história" (Rodrigues, 1991: 263).

Essa particularidade histórica fez com que o intelectual carioca procurasse apontar como nesse momento houve a possibilidade de criação do Estado organizado segundo as prerrogativas do liberalismo político e como esse projeto fora abortado com a prisão dos principais articuladores Constituinte de 1823. Entre esses liberais que procuravam colocar em prática uma Constituição de caráter liberal tínhamos a figura de José Bonifácio.

A análise honoriana a respeito da emancipação política do Brasil atribui um peso decisivo à figura de José Bonifácio como elemento primordial para o entendimento dos desdobramentos dos Sete de setembro de 1822. A esse personagem atribui a consolidação da independência e a manutenção da unidade nacional. “(...) Personagem histórico e herói nacional, homem e mito, aparece nos compêndios como figura de destaque, sempre vinculado de forma decisiva aos resultados do processo de emancipação política" (Costa, 1999: 61). 
Eclode em Portugal, em 1820, a Revolução Liberal do Porto ${ }^{65}$, isso acabou gerando um conjunto de condições que permitiram a José Bonifácio uma participação decisiva junto à organização política no período inicial da monarquia. $\mathrm{O}$ movimento de 1821 no Porto almejava “... a organização constitucional do país, a instalação das Juntas Governativas" instituídas por deliberação das cortes portuguesas, mas não significava uma ruptura definitiva com o passado. "A intenção era introduzir em Portugal e no Brasil um regime constitucional.” (Costa, 1999: 64).

Inicialmente, não eram claras as intenções de Portugal para recolonizar o Brasil, em seus primeiros momentos, o movimento ganhava ares de inspiração liberal contrária ao absolutismo do Estado português. O próprio D. João VI, obrigado a retornar a Portugal por causa da Revolução, não se opunha de forma clara aos rumos que constitucionalmente o "Reino Unido" ia adquirindo.

Foi nessas condições que José Bonifácio apareceu pela primeira vez na cena política brasileira. Quando se indicaram os representantes brasileiros às Cortes de Lisboa, a Junta Governativa de São Paulo redigiu uma série de construções para orientar os deputados paulistas. Subscritas por todos os membros do governo provisório de São Paulo, as "Lembranças e Apontamentos" têm sido, entretanto, atribuídas a José Bonifácio, por coincidirem suas linhas gerais com seus pontos de vista. Nada havia no texto que revelasse a menor intenção de

\footnotetext{
${ }^{65} \mathrm{O}$ historiador português Antonio Sergio descreve o processo da Revolução Liberal de Portugal como um momento crucial do Estado português, assim, afirma que: “(...) O certo é que a soberana D. Maria I endoideceu, e que assumiu a regência o príncipe D. João, mais tarde D. João VI (1792). As ideias renovadoras, propagadas pela Revolução Francesa, eram introduzidas, sobretudo pelos comerciantes estrangeiros, e alarmavam os governantes. Estes, desprezando o conselho da Inglaterra, aliaram-se a Espanha contra a França revolucionária, mandando um contingente aos Pirineus (1793-1795). A Espanha, depois, vindo a aliar-se com os Franceses, declarou guerra à Inglaterra (1796) e negociou a partilha de Portugal. Debatemo-nos então entre França e a Grã-Bretanha. As variações da nossa política, porém, tão ridicularizadas pelos historiadores, explicam-se pela existência de dois partidos em Portugal: francófilo um, anglófilo o outro, cujas forças se equilibravam. Por fim, Napoleão, aliado aos espanhóis, fez invadir Portugal por um exército francês, comandado por Junot, e três exércitos espanhóis (novembro de 1807). O príncipe enveredou pelo caminho que se lhe abria, previsto em Portugal desde o século XVII, e aconselhado pela Inglaterra: embarca para o Brasil. (...) A 20 de março de 1816 morre a rainha e o príncipe regente é levado a condição de rei. Este continuava no Brasil. Haviam-se invertido os papéis da metrópole e da colônia. A ida da corte, acompanhada de uma elite portuguesa, dera ao Brasil um grande impulso, encaminhando-o para a independência. $\mathrm{O}$ ato que para este mais concorreu foi a abertura dos portos aos estrangeiros. (...) Em Portugal governava Beresford. O descontentamento dos militares suscitou a conjuração de 1818, que custou a vida a Gomes Freire. Quando, em 1820, o general inglês foi ao Brasil, o Porto sublevou-se. Os oficiais britânicos receberam ordem de retirar; não se permitiu o desembarque de Beresford, à volta a do Rio; e nomeou-se uma nova regência, convocando-se uma assembléia para elaborar uma constituição ( a de 1822, radical, quimérica, absolutamente inadaptável as condições do país). A Inglaterra insistiu com o rei para que voltasse para a metrópole, o que ele fez, deixando no governo do Brasil o filho mais velho, D. Pedro. Chegando a Lisboa, o monarca jurou a Constituição; mas a rainha, D. Carlota Joaquina, e o filho mais novo, D. Miguel, puseram-se à frente do partido absolutista. (...) Os radicais, muito liberais para consigo mas pouco para o Brasil, provocaram neste uma reação que levou o príncipe D. Pedro a proclamar-lhe a Independência, ficando seu imperador." (Sérgio, 1979: 129).
} 
independência. Tratava apenas de firmar os princípios liberais que inspiravam, aliás, os revolucionários do Porto, e de garantir as regalias obtidas pelo Brasil desde a vinda da Corte em 1808, entre os quais a autonomia administrativa, no que evidentemente divergia dos objetivos dos revolucionários portugueses, desejosos de anular as medidas liberais que, permitindo ao estrangeiro o acesso direto às mercadorias brasileiras, prejudicaram os comerciantes e os produtores portugueses. (Costa, 1999: 66).

Nos apontamentos ${ }^{66}$ se afirmava a necessária defesa da integridade e indivisibilidade do Reino Unido, declarando-se que as nossas atuais possessões em ambos os hemisférios serão mantidas e defendidas contra qualquer força externa que as “pretender atacar ou separar”, além disso, ressaltava “... a necessidade de princípios igualitários para a prática política e também permitir a diversidade dos costumes e território, e das circunstâncias estatísticas.” (Bonifácio, 2002: 126).

Além disso, o papel de José Bonifácio na defesa dos direitos políticos no Brasil foi enorme. Um bom exemplo é se compararmos o que foi oferecido a sociedade com a Constituição Imperial de 1824, frente às "Instruções de Bonifácio", que eram mais contundentes e claras quanto ao direito legítimo de voto da população. Nesse sentido, era considerado cidadão com direito de voto todo homem que fosse casado e todo aquele que tivesse acima de vinte anos. Segundo Jose Honório Rodrigues:

A Constituição de 1824 manteve a distinção entre solteiro e casado e excluía de votar os menores de 25 anos, nos quais se não compreendem os casados e os oficiais militares, que forem maiores de 21 anos, os bacharéis formados e clérigos de ordens sacras. Não só estavam excluídos os cidadãos entre 20 e 24 anos, antes admitidos, como os casados viam reduzidos seus direitos políticos, antes sem limitação de idade. Estas limitações não eram compensadas pela inclusão de oficiais militares, bacharéis e clérigos, já que antes todo solteiro maior de 20 anos podia votar. As Instruções de José Bonifácio foram, assim, mais liberais que a própria Constituição Imperial, e os decretos e leis que seguiram mantiveram estes limites de idade. Quando se discutiu a Lei Saraiva-Rui

\footnotetext{
66 " $1{ }^{\circ}$ Integridade e indivisibilidade do reino; declarando-se que as nossas atuais Possessões em ambos os Hemisférios serão mantidas e defendidas contra qualquer força externa, que as pretender atacar ou separar. $2^{\circ}$ Igualdade de Direitos Políticos, e dos Civis, quanto o permitir a diversidade dos costumes e território, e das circunstâncias Estatísticas.” (Bonifácio, 2002: 96).
} 
Barbosa, defendeu-se também a redução da idade de 25 anos para 21 anos, e, como sempre, houve protestos contra a ampliação dos direitos políticos, reformando-se a Constituição por lei ordinária. Afinal elevouse novamente a idade e a redação vitoriosa não ampliou o exercício do direito político. (Rodrigues, 1965: 171).

José Honório, ao avaliar esses Apontamentos e as Indicações, acenava para a radicalidade do programa político elaborado por José Bonifácio. Sendo assim, destacou propostas que versavam sobre a igualdade dos direitos políticos aos países associados à família real portuguesa, além de ressaltar a necessidade da declaração das atribuições e poderes que competiam aos integrantes do "Reino Unido de Portuga"67, condição em que o Brasil se inseria, e como deveria ocorrer sua relação com o Império. A ação política de Bonifácio fora tomada de modo autêntico na interpretação honoriana. Trata-se de uma nítida oposição ao pensamento conservador que ganhava espaço junto à elite oligárquica brasileira ${ }^{68}$.

Em sua proposta Bonifácio argumenta que:

Considerando quanto convém ao Brasil em geral, e a esta província em particular, que haja uma nova legislação sobre as chamadas sesmarias, que sem aumentar a agricultura, como se pretendia, antes tem estreitado e dificultado a povoação progressiva e unida; porquanto há sesmarias de seis, oito e mais léguas quadradas, possuídas por homens sem cabedais e sem escravos, que não só as não cultivam, mas nem sequer as vendem e repartem por quem melhor as saiba aproveitar; originando-se daqui que as povoações do sertão se acham muito espalhadas e isoladas por causa dos imensos terrenos de permeio, que não se podem repartir e cultivar por serem sesmarias; seguindo-se também daqui viver a gente do campo dispersa, e como feras no meio de brenhas e matos, com sumo prejuízo da administração da justiça e da civilização do país; parece-nos por todas estas razões muito conveniente que, seguindo-se o espírito da lei do senhor d. Fernando (rei de Portugal entre 1367 e 1383) sobre esta matéria, que serviu de fonte ao que está determinada nas Ordenações, se legisle que: $1^{\circ}$ ) que todas as terras que foram dadas por sesmaria, e não se acharem cultivadas

\footnotetext{
${ }^{67}$ Segundo José Murilo de Carvalho, essa condição só seria modificada em agosto de 1825 com a assinatura do Tratado do Rio de Janeiro. Carvalho (2006), ver também Mattos (2004).

${ }^{68}$ A respeito do pensamento conservador ver: Mercadante (1965)
} 
entre outra vez na massa dos bens nacionais, deixando somente aos donos das terras meia légua quadrada quando muito, com a condição de começarem logo a cultivá-las em tempo determinado, que parecer juntos." (Bonifácio, 2002: 131) (Grifos nosso).

Para que fossem realizadas várias reformas, de modo a permitir que as terras não cultivadas entrassem de novo na massa dos bens nacionais, deixando-se somente aos "donos das terras meia légua quadrada quando muito, com a condição de começarem logo a cultivá-la em tempo determinado; que os que tinham feito suas as terras só por mera posse, as perdessem, exceto o terreno cultivado." (Rodrigues, 1972: 190). Essa ação de José Bonifácio, que foi realizada com a anuência do imperador, é um exemplo sintomático da preocupação que um conciliador com as classes subalternas deve procurar enfatizar, pois aqui teríamos um caso clássico da ideia de conciliação que almejava “... a ruptura com os pressupostos institucionais da política ao longo de nossa história, e mais, uma proposta que integrava as massas populares em projeto nacional e popular." (Rodrigues, 1965: 12).

Sendo a questão da propriedade fundiária - questão de terras na terminologia de Honório - uma aspiração legítima e contínua da sociedade brasileira, as lideranças que vislumbram uma prática conciliadora devem tê-la como meta primordial. Não que Bonifácio fosse a favor de um projeto de reforma agrária, mas a preocupação para com as terras visava ao maior controle e organização das mesmas de acordo com os interesses da massa populacional que se encontrava alijada de qualquer melhoria em sua condição de vida.

Essa postura de questionar o absolutismo e chamar a atenção da corte para a necessidade de ocupar também a região central do Brasil, defendendo a integração territorial e a manutenção da unidade nacional, fez com que José Bonifácio apresentasse, segundo a análise honoriana, o papel de homem público que propunha um plano de governo que causou impacto em Portugal, haja vista sua radicalidade. A postura de Bonifácio logo fez com que em Portugal fosse notado que na antiga colônia existia um "estadista e sobre ele recairia o ódio do Congresso, dos publicistas, dos jornalistas, dos políticos portugueses. D. Pedro descobria nestes Apontamentos o candidato natural à chefia do governo nacional” (Rodrigues, 1972: 49).

O passo seguinte para a concretização de um Estado, seguindo o modelo americano de democracia-federalista e liberal, que apresentasse legitimamente 
condições de considerar-se emancipado politicamente era a confirmação de uma Constituição que fosse legítima representante dos interesses dos brasileiros. O programa político apresentado por José Bonifácio foi, para a condição de conciliador atribuído a ele por José Honório, o mais expressivo naquele contexto. A proposta de Bonifácio fora impregnada pelo movimento reformador de Pombal ${ }^{69}$, além disso, tínhamos, na figura do "grande conciliador", um ator do processo político que acreditava que o esforço intelectual seria determinante para a construção de uma "identidade nacional" (Bonifácio, 2002).

Entre os aspectos a serem destacados do plano político de Bonifácio, há que se ressaltar que sua meta era salientar a necessária, porém gradual emancipação dos escravos. Nesse sentido, seu projeto era inovador, uma vez que pretendia integrar as massas à sociedade que estava constituindo-se naquele momento. Ainda nessa perspectiva, defendia a ideia de uma formação intelectual para a maioria da população. Considerando que não poderia existir um governo constitucional que durasse sem oferecer à população uma instrução mais digna, lembrava que além das escolas de primeiras letras em todas as vilas e cidades, eram necessários ginásios e colégios em que se ensinassem as ciências úteis, para que nunca faltassem, entre as classes mais abastadas, homens que não só servissem aos empregos, mas igualmente fossem capazes de espalhar pelo povo “... os conhecimentos que são indispensáveis para o aumento da riqueza e prosperidade da nação." (Rodrigues, 1972: 189).

Propunha ainda que cada província tivesse as seguintes cadeiras de ensino superior: medicina teórica e prática; cirurgia e arte obstetrícia; veterinária; matemática; física; química; botânica; horticultura experimental; zoologia e mineralogia. Além dessas cadeiras seria criada pelo menos uma Universidade que deveria constar das seguintes Faculdades: uma de Filosofia, composta de três colégios, o de ciências naturais, o de matemáticas puras e aplicadas, e o de filosofia especulativa e boas artes; uma segunda, de medicina, uma terceira, de jurisprudência; e uma quarta, de economia, fazenda e governo. Cada Faculdade teria as cadeiras necessárias para o completo ensino de todos os conhecimentos humanos. A teologia poderia ser ensinada nos seminários episcopais, para que tivéssemos clero douto e capaz, o que absolutamente faltava ao Brasil. Defendia

\footnotetext{
69 Segundo Francisco Weffort, Bonifácio reconhecia o mérito do legado Pombalino: “Ao lado das inovações, a continuidade é o traço dominante do pensamento de José Bonifácio. As ideias propostas para o nascente Brasil se alinham, com algumas significativas exceções, com as ideias e propostas que poucos anos antes ele apresentava a D. Maria I, então rainha de Portugal. Quase tudo segue a mesma lógica do iluminista. Como se fora um texto de um discípulo de Pombal e Verney, Bonifácio não se esquece de elogiar algumas das obras do marquês, embora sem mencionar-lhe o nome." (Weffort, 2006: 173).
} 
a localização da Universidade em São Paulo, por causa do clima, da barateza e abundância de comestíveis, da fácil comunicação e da existência de edifícios próprios: os conventos do Carmo, São Francisco e São Bento. (Rodrigues, 1972: 190).

Outro elemento que fica evidente entre as propostas de José Bonifácio era a ideia de mudança de capital, vislumbrando a criação de uma localidade central para o estabelecimento da família real, sem que essa sofresse qualquer ameaça de enfrentamento externo, e evitando, assim, qualquer tipo de levante das "populações vadias das cidades marítimas" (Rodrigues, 1972). Essa "corte central" seria um lugar de ligação para boa parte do território, consolidando, dessa forma, a integração e a unidade, permitindo que as ordens do governo fossem rapidamente atendidas nas extremidades do país e que a extensão territorial não se apresentasse, em hipótese alguma, como um problema para o poder imperial. Nessa cidade central seriam criados um Tribunal Superior de Justiça, um Conselho de Fazenda e uma direção geral da economia pública.

Também foi mérito de Bonifácio apontar a necessidade de uma nova legislação sobre sesmarias, porque estas, sem aumentar a agricultura, como se pretendia, antes havia estreitado e dificultado a povoação progressiva e unida, “... havendo sesmarias de seis, oito e mais léguas quadradas, possuídas por homens sem cabedais e escravos"(Rodrigues, 1972:), que, além de não demonstrar nenhum apreço sobre a terra, não as cultivavam e muito menos as disponibilizavam para venda ou repartiam para quem tivesse melhores condições "técnicas" de uso. Dessa prática originava-se, aponta José Honório Rodrigues, a condição para que o povoamento do sertão ficasse cada vez mais disperso e isolado, sobretudo, "aos imensos terrenos de permeio", que não eram repartidos por serem sesmarias, decorrendo daí: “... viver a gente do campo dispersa, e como feras no meio das brenhas e matos, com sumo prejuízo da administração da Justiça e da civilização do país." (Rodrigues, 1972: 192).

A prática do político de Santos reforça a admiração de José Honório, nesse sentido, realça sua ação como homem público, como elemento de alta confiança do Imperador e que, portanto, estava em condições de pleitear medidas que fossem dignas de sua posição e, principalmente, fossem meritórias por modificar a organização social do país, principalmente criando mecanismos para que houvesse uma maior conciliação com os setores subalternos ou, utilizando de expressão importante no legado honoriano, melhorar a vida do povo brasileiro. Seu posicionamento a favor de uma 
prática política liberal foi sua meta ao longo do processo constituinte de 1823, que fora abortado de forma violenta pelo imperador. O resultado da Constituinte é que o pensamento conservador foi calcado na manutenção dos princípios de poder que, por sua vez, impossibilitou a modernização da sociedade, a maior autonomia do povo e um distanciamento dos princípios do liberalismo político.

$\mathrm{Na}$ análise do intelectual carioca, as ações de Bonifácio não são indícios de uma atuação revolucionária, mas sim da preocupação em superar os limites instituídos por anos de jugo, impondo aos moldes do exemplo europeu. Isto é, um sistema representativo de monarquia parlamentar, com as instituições que representam esse sistema político funcionando e, consequentemente, dinamizando cada vez mais a sociedade brasileira. Conforme ressaltou José Honório:

Interpretando a lei de D.Fernando, propunha José Bonifácio varias reformas, de modo a permitir que as terras não cultivadas entrassem de novo na massa dos bens nacionais, deixando-se somente aos donos das terras meia légua quadrada quando muito, com a condição de começarem logo a cultivá-la em tempo determinado; que os que tinham feito suas as terras, que revertessem por este modo à Nação, e de todas as outras que estivessem vagas, não se dessem mais sesmarias gratuitas, mas se vendessem em porções ou lotes, que nunca pudessem exceder de meia légua quadrada; que se criasse uma caixa com o produto dessas vendas, que seria empregado em favorecer a colonização dos europeus pobres, índios, mulatos e negros forros, a quem se havia de dar de sesmaria pequenas porções de terreno para cultivarem e se estabelecerem; que em todas as vendas que se fizessem e sesmarias que se dessem se pusesse a condição de que a sexta parte do terreno nunca havia de ser derrubada e queimada, sem que se fizessem novas plantações de bosques, para que nunca faltassem as lenhas e madeiras necessárias; que de três em três léguas se deixasse pelo menos uma légua intacta, para se criarem novas vilas e povoações e quaisquer outros estabelecimentos de utilidade pública. (Rodrigues, 1972: 192).

Como grande mineralogista que foi, pedia atenção para as condições de exploração das minas de ouro por serem estas de suma importância para a sobrevivência das populações da região central do país, além de manter uma renda que permitiria a essa população a manutenção das relações comerciais com os portugueses. Não só o ouro era sua preocupação, mas todos os metais úteis presentes em território nacional: 
“... pois não há província no Brasil, seja de beira-mar, ou de sertão, que mais ou menos não contenha minerais, que para serem aproveitados só esperam por maior instrução nacional e mais ativo fomento do governo.” (Bonifácio, apud, Rodrigues, 1972).

A grandeza explícita nas ações de José Bonifácio foi condizente a sua importância no processo de consolidação do regime monárquico instalado em 1822. O entendimento das condições típicas em que o Brasil se encontrava naquele cenário fez com que sua prática social fosse em prol da instalação de um governo que trouxesse uma maior dinâmica das instituições que legitimavam o Estado, recentemente constituído, bem como em favor de que a população deveria ter seus direitos instituídos. Bonifácio "foi sempre intransigente quando se tratava do interesse nacional", foi terminantemente contra a admissão de oficiais portugueses nos postos de confiança, para que os verdadeiros e legítimos herdeiros daqueles postos não fossem subjugados, isto é, os brasileiros, que eram chamados pelos “... áulicos de negros e botocudos” (Rodrigues, 1964: 35).

A condição de conciliador, esse entendido como forma de integração das camadas subalternas, do Povo, como grafava José Honório, foi sempre a meta de Bonifácio. Suas propostas de reformas eram fundamentais para que: "talvez tivesse evitado que tanto derramamento de sangue corresse durante a Regência." (Rodrigues, 1972: 192). Segundo o autor nenhum homem público no Brasil, nessa época, propunha todo um plano de governo como este foi por José Bonifácio. Era natural o impacto que causou no Brasil e em Portugal. Aqui ele se tornou o chefe natural do movimento político de emancipação, apesar da sua ideia inicial da integridade e indivisibilidade do Reino. Era sob a máscara da autonomia dentro da união que a Independência caminharia para a vitória. "Em Portugal, viu-se logo que o Brasil tinha um estadista e sobre ele recairia o ódio do Congresso, dos publicistas, dos jornalistas, dos políticos portugueses." (Rodrigues, 1972: 195)

O desfecho do papel de "líder" de José Bonifácio foi o exílio e a impossibilidade de levar adiante a consolidação de uma monarquia constitucional, proposta que foi abortada pela conspiração levada adiante pelo príncipe regente ao outorgar a Constituição de 1824 e frear todos os possíveis avanços liberais que a Constituinte em 1823 propunha. Cabe destacar que, sendo um importante interlocutor e articulador de um projeto que limitava o poder do Imperador, José Bonifácio foi banido país e, dessa forma, impedido de levar adiante seu projeto nacional. 
A medida adotada que levou à dissolução da Constituinte, em 1823, desencadeou a crise política que, ao longo do primeiro reinado, foi incessante e teve seu desfecho com a abdicação em sete de abril de 1831. A partir desse cenário, a concepção conspiratória da história e a procura de representantes do radicalismo tornaram-se uma prática comum da elite proprietária e contrária a uma "conciliação com o Povo". Ao conciliador Bonifácio restou receber a afronta, "tendo sofrido na carne e no espírito a acumulação de ódios, agora não mais dos portugueses conluiados aos exaltados, mas dos moderados, dos liberais anti-reformistas." (Rodrigues, 1986: 41). Cabe destacar que a identificação da ação prática de José Bonifácio reforça, ao nosso entendimento, o valor do seu discurso liberal, antiabsolutista, o aproxima do ideal de modernização da sociedade vislumbrado por José Honório, isto é, uma "via americana" de desenvolvimento da sociedade brasileira.

\section{3 - O liberalismo conciliador de Tavares Bastos: O político da integração territorial e do federalismo}

Em alguns momentos da produção intelectual de José Honório Rodrigues, temos a informação que, para suas convicções, a figura de José Bonifácio fora a maior expressão política que o Brasil já teve. Todavia, a evocação ao político Tavares Bastos sempre aparece de forma eloquente. A perspectiva honoriana, quando o assunto é o pensamento do deputado Aureliano Cândido Tavares Bastos, remete à admiração que esse político suscitou no intelectual carioca. Tendo vivido apenas 36 anos, sua vida pública começa em 1861, como deputado geral e como escritor. Reeleito em 1864 e em 1868, exerceu sete anos e meio de atividade parlamentar. José Honório tece os seguintes comentários a respeito deste percurso curto, porém expressivo do ponto de vista intelectual:

Não há na história parlamentar e na história política exemplo de realização semelhante em tão breve tempo. E, sobretudo quando se considera sua obra como importante pela influência que exercia na sua época, e que perdurou a te hoje como expressão efetiva, lúcida e bem exposta do pensamento liberal socialmente moderado, progressista, como se autodenominava o grupo de Tavares Bastos, mas certamente liberais-imperialistas, sectários da ideologia liberal protestante, maçônica, republicana anglo-americana. Neste sentido ele 
foi inteiramente engajado e comprometido, quer na imprensa, quer no Parlamento ou ainda nos livros. (Rodrigues, 1976a: 9).

É necessário destacar também que o histórico a respeito do liberalismo no Brasil durante o período monárquico passa, sem dúvida, pela ação desse jovem liberal. Segundo a professora Walquiria D. Leão Rego:

Outros liberais e outros liberalismos houve ao longo do período imperial. Tivemos nossa experiência de liberalismo mais radical, talvez mais próxima da tradição republicano-democrática rousseauniana, com Frei Caneca, na revolução de 1824. Pode-se dizer que, nas revoluções de 1817, 1824 e nos movimentos políticos que culminaram com o Ato Adicional de 1834, de algum modo foi posta a questão da soberania popular e da fundação de suas instituições políticas. Após a reação monárquica-conservadora de 1840, nosso liberalismo de um modo geral, envolveu-se na organização das instituições do Estado, dando continuidade a uma experiência histórica paradoxal, ou seja, os liberais da independência já haviam participado da fundação de um Estado fortemente centralizado. (...) É verdade que isso não contraria fundamentalmente a tradição oriunda do "liberalismo pombalino". Contudo, é sempre bom lembrar que o liberalismo como corpo doutrinário redefiniu muito de seus conteúdos em função das diferentes realidades históricas. Ou seja, como qualquer doutrina, o liberalismo foi impelido pelas circunstâncias históricas dos diferentes países a redefinições político-institucionais. (Rego, 1993: 76).

No caso brasileiro, a peculiaridade do liberalismo revela o quanto nossa ordem institucional fora legitimada pelo "constitucionalismo da reforma pombalina" (Faoro, 2007), ou seja, não houve a condição do exercício de uma organização federalista que conduzisse a transição do Estado em sua fase larval, isto é, como um apêndice da Metrópole, ao surgimento de uma instituição que tivesse autonomia e fosse conduzida pelo liberalismo político. Ao longo dos anos de colônia, a falta de projetos que tivessem como foco a melhoria da organização política social e, no seu limite, a ruptura com nossa condição de "desterrados",70, explica bem o quanto nos foi suprimida

\footnotetext{
${ }^{70}$ A formulação "desterrados em nossa própria terra" é de Sérgio Buarque de Holanda que sentencia: "A tentativa de implantação da cultura européia em extenso território, dotado de condições naturais, se não adversas, largamente estranhas à sua tradição milenar, é, nas origens da sociedade brasileira, o fato dominante e mais rico em consequências. Trazendo de países distantes nossas formas de convívio, nossas instituições, nossas ideias, e timbrando em manter tudo isso em ambiente muitas vezes desfavorável e hostil, somos ainda hoje uns desterrados em nossa terra. Podemos construir obras excelentes, enriquecer
} 
a possibilidade de gestação de um Estado que fizesse desabrochar uma Nação com instituições minimamente organizadas.

É com o pensamento voltado para a condição de organização do liberalismo na sociedade brasileira, principalmente na segunda metade do século XIX, que Tavares Bastos ganha destaque com sua atuação política e sua defesa intransigente de uma maior dinâmica para a sociedade brasileira. Essa apresentava obstáculos quase incorrigíveis no que diz respeito a aspectos como: integração nacional, Estado federalizado, poderes constituídos de forma integrada e equilibrada, ou seja, a forma de ação do pensamento derivado da manutenção da ordem colonial implicaria no fato de que; "somos um país que, mesmo com a independência, mantemos a constituição da exmetrópole organizando nossa vida social" (Rodrigues, 1965). Faltaria no Brasil a formação de uma sociedade em que o liberalismo político seria a base ideológica de organização do Estado. Segundo a análise de Werneck Vianna:

A Independência do Brasil consistiu numa ruptura real, pondo todo o subcontinente diante do imperativo de fazer história, e se o liberalismo político tinha sido a ideia-força do movimento, agora seria traduzido em instituições que se sobreporiam a uma realidade social adversa, quando não incompatível com ele - como no caso do trabalho escravo ou servil. O liberalismo político nasce, portanto, sob o estigma da ordem e da autoridade, com a função de fornecer sustentação ideal ao estabelecimento de um Estado nacional, e não para consagrar a liberdade. (Werneck Vianna, 2004: 155).

José Honório Rodrigues toma posse na Academia Brasileira de Letras em 5 de dezembro de 1969, eleito após a morte de Rodrigo Otávio Filho, passando a ocupar a cadeira de número 35. Seu discurso de posse foi centrado na figura do patrono da cadeira: Tavares Bastos. Transcrevemos parte desse discurso, pela contundência com que o intelectual remete à atuação do político alagoana, interpretando-o como mentor de um liberalismo que propunha impor mudanças substanciais à forma de conduta e controle do Estado. A inoperância e o pensamento conservador da elite política poderiam ser abalados por um intelectual que propunha durante a monarquia; eleições diretas, federalismo, abertura do Amazonas, liberdade para a navegação de cabotagem,

nossa humanidade de aspectos novos e imprevistos, elevar à perfeição o tipo de civilização que representamos: o certo é que todo o fruto de nosso trabalho ou de nossa preguiça parece participar de um sistema de evolução próprio de outro clima e de outra paisagem. (...) Assim, antes de perguntar até que ponto poderá alcançar bom êxito a tentativa, caberia averiguar até onde temos podido representar aquelas formas de convívio, instituições e ideias de que somos herdeiros. (Holanda, 1995: 31). 
utilização de mão-de-obra imigrante e maior aproximação com os Estados Unidos da América. Em seu discurso na Academia Brasileira de Letras, afirma que:

Aureliano Cândido Tavares Bastos, patrono desta cadeira, nasceu e se educou sob o domínio conservador, mas se iniciou na política quando recomeçava, no dizer de Joaquim Nabuco, a encher a maré democrática, que se tinha visto continuamente baixar desde a reação monárquica de 1837, e cuja vazante, depois da Maioridade, chegara a ser completa. (...) Apesar do predomínio conservador, a leitura dominante da elite intelectual era romântica e liberal. Um português miguelista, que aqui viveu entre 1828 e 1842, escreveu com espanto que "Thiers, Lamartine e Guizot e outros, cuja fama não morre, são as leituras e textos dos homens de Estado deste país". (...) Não posso entrar no exame das influências românticas e liberais que formaram o espírito de Tavares Bastos, o mais orgânico, o mais sistemático e o mais lúcido pensador político que o Brasil já produziu. Ele não foi só um grande homem, apesar de sua mocidade, mas, sobretudo uma cultura. A extensão e profundidade de seu espírito, a claridade de sua consciência o torna uma exceção, não somente em sua época, como até hoje, pela capacidade de enlaçar a teoria e prática políticas e de incorporar toda a cultura de um povo. (Rodrigues, 1969: 181).

A identificação com o liberalismo defendido por Tavares Bastos aponta o caminho do desenvolvimento político e social que o país deveria seguir. A defesa da unidade territorial, do sistema federalismo, das eleições livres entre outros, faz com o intelectual carioca vislumbre uma liderança de grande contribuição para a modernização do Estado brasileiro. Ao nosso entendimento, o projeto "americanista" de Bastos faz com Honório identifique nele o grande liberal que procurava "enlaçar a teoria e prática políticas e de incorporar toda a cultura de um povo." (Rodrigues, 1969).

Influenciado pela teoria romântica da História, ele se apóia sobre a experiência do passado mais recente e do tempo presente, alimenta-se da história nacional e nela busca o gênio do povo brasileiro. (...) Afirmou Tavares Bastos, nas Cartas do Solitário, publicadas em 1862, quando contava apenas 23 anos: "Conservador e liberal, monarquista e democrata, católico e protestante, eu tenho por base de todas as minhas convicções a contradição; não a contradição mais palavrosa do que inteligível das antinomias de Proudhon, porém a contradição entre duas ideias que na aparência se repelem, mas na realidade se 
completam a contradição, finalmente, que se resolve na harmonia dos contrastes". E acrescenta, logo a seguir: "Guio-me pelos fatos, combino os apostos, encadeio as analogias e construo a doutrina. Não tenho sistemas preconcebidos. Não idolatro o prejuízo. Aceito o sistema que os acontecimentos me impõem". Vê-se aí o conceito de natureza social das contradições, e o sentido de sua crítica total à sociedade, realizada nos seus livros e folhetos, como forma de uma tensão no seio da própria realidade social. Não é uma lógica conformista que nega a realidade das contradições, é antes uma crítica ao estado existente de coisas, conduzida no próprio terreno das contradições, uma crítica ao sistema, que renega suas próprias promessas e suas próprias possibilidades. (...) Este é um aspecto fundamental da obra de Tavares Bastos, na qual o processo político é sempre um processo histórico e dialético. O passado, o presente e o futuro estão unidos, e a construção de suas teses se faz de forma inteiriça. (Rodrigues, 1969: 181).

O intelectual, adjetivado positivamente por José Honório, teve sua atuação política pautada pelo intuito de uma organização que fosse similar à americana, tal como o exposto por Alexis de Tocqueville ao descrever A democracia na América, ressaltou que os valores ético-políticos determinam à condição de interpretar a sociedade e como essa pode oferecer maior liberdade a parcela expressiva da sua população $^{71}$.

A forma de pensamento conservador que prevalece na sociedade após a Outorga da Constituição em 1824 criou um sistema político impossibilitou um governo que governasse às instituições, visando a superação dos obstáculos que a monarquia criava. E nessa contenda de uma sociedade amorfa, sobretudo se comparada ao modelo liberal anglo-saxônico, Tavares Bastos posicionava-se, contra integrantes do cenário político, que por meio de uma proposta ancorada nos preceitos do "americanismo". Ao

\footnotetext{
${ }^{71}$ Segundo o estudo de Marcelo Jasmim: "O dilema tocquevilleano se constitui da contraposição entre um diagnóstico "científico" da sociedade moderna - que retrata as disposições que tendem a inviabilizar a liberdade política nas condições sociais igualitárias - e uma necessidade ético-política de afirmar a exeqüibilidade desta mesma liberdade no contexto da destruição da participação política e da cidadania que decorre do desenvolvimento daquelas disposições. Essa tensão irresolúvel entre ciência e política, determinação e vontade, natureza e arte, é o leitmotiv da reflexão tocquevilliana e será trabalhada exaustivamente e de muitos modos ao longo de sua obra. (...) Desde logo, deve-se notar que tal tensão é constitutiva do próprio sistema conceitual de Tocqueville que opera pela justaposição de dois niveis distintos, formados, cada um deles, por pares de conceitos opostos. No primeiro nível, opõem-se democracia e aristocracia para dar conta do processo histórico da constituição das modernas sociedades igualitárias e definir a natureza. No segundo, a polarização entre liberdade e servidão indica que há e quais são as possibilidades de ordenação da vida política na democracia. (Jasmin, 2005: 39)
} 
nosso entendimento esse foi o principal elo de identificação entre José Honório Rodrigues a Tavares Bastos.

O que deve ser destacado em todo legado da ação política de Tavares Bastos é que, para além de sua defesa intransigente dos princípios do liberalismo, a questão do federalismo, a integração territorial e a proposta de uma reestruturação da propriedade de terra, mostravam a amplitude e sua proposta reformista. Porém, a questão escravista não era foco, pelo menos dos mais expressivos, de suas inquietações, o foco da crítica liberal era endereçada às instituições políticas do Estado, deixando a escravatura de lado. Segundo a professora Walquiria D. Leão Rego:

A instituição escravista, que sustentava a acumulação econômica, não constituía, pelo menos durante este período, um dilema de grande porte à consciência liberal. Pode-se conjecturar: a exigência liberal cessaria numa reforma das instituições políticas que, reformadas, poderiam tranquilamente guiar seu curso nos quadros de uma monarquia "verdadeiramente parlamentar", mesmo que sustentada economicamente por um regime de trabalho - a escravidão - que por sua natureza jamais poderia engendrar "indivíduos autônomos", condição sine qua non da cidadania liberal. (...) Esta ambivalência das ideias e da política culminará, em 1855, com a chamada "política da conciliação", que de certo modo consubstanciava o tempo liberal como tempo liberal como tempo de "liberalismo regressista". (Rego, 1995: 76).

O político alagoano era responsável pela defesa dos preceitos de uma instituição que apresentava uma lógica de funcionamento que pautava-se pelo americanismo - tal como elaborado por Alexis de Tocqueville. Esse ideal chegava a nós, pois para Tavares Bastos a grande riqueza que os Estados Unidos alcançara nos oitocentos era graças à ordem democrática e federalista que serviu de organização àquele país.

Cabe destacar que vínhamos de um processo reformista que, desde a abdicação em 1831, ganhava força e espaço, exemplo maior dessa mudança foi quando a Câmara aprovou um projeto de reforma constitucional, com nítido intuito de criação de uma monarquia constitucional. Com propostas de embate ideológico e político de ampla contundência colocando em xeque a própria instituição da monarquia, o projeto não foi aceito pelo Senado.

Todavia, o debate ganhou força e uma disputa entre dois grupos bem delineados estava evidente. De um lado, uma elite reformista entusiasmada pelo modelo 
norte-americano, de outro pelo lado a elite educada em Coimbra, o grande receio de fragmentação do país se as reformas fossem levadas a adiante, o maior medo desse grupo era a copia às instituições americanas, em particular o federalismo. Como solução para esse embate chegou-se ao Ato Adicional de 1834 que adotou alguns elementos federais como as assembléias provinciais, a divisão de rendas e a eliminação do Conselho de Estado ${ }^{72}$. Não foram aceitos o fim da vitalicidade do Senado, a extinção do Poder Moderador e a criação de executivos municipais. Segundo José Murilo de Carvalho:

$\mathrm{O}$ ato adicional, mesmo sendo versão moderada das reformas, deu origem ao que muitos chamaram de experiência republicana do Império. A afirmação é pertinente, pois na menoridade do Imperador o regente seria eleito pelo voto popular. No que refere a federação, faltava apenas a eleição dos presidentes de província para que o sistema se aproximasse do modelo americano. Consequência ou não da descentralização (o tema foi matéria de discussão entre liberais e conservadores), manifestaram-se por todo o País as tendências centrífugas sob lideranças regionais que não tinham compromisso forte com a unidade nacional. (Carvalho, 1998: 166).

Com o cenário político extremamente complexo a partir de 1834, a eclosão de um grande número de revoltas foi o que acabou caracterizando a história cruenta, como definiu por José Honório. Assim, o período regencial deve ser considerado como um dos contextos políticos de maior violência contra os setores subalternos. Essa condição de grande instabilidade política fez com que houvesse na Câmara debates acalorados a respeito da retomada da centralização política. Em 1837, fora instituído o "Regresso Conservador" ${ }^{73}$, que promoveu ao retorno da centralização

\footnotetext{
${ }^{72}$ Cabe destacar que o período posterior a Ato Adicional de 1834 foram anos de grande instabilidade no país, a respeito Gabriela Nunes afirma que: "Os anos que se seguiram ao Ato Adicional estão de fato entre os mais conturbados da história do Império, com ameaças reais à unidade nacional. Entre $1835 \mathrm{e}$ 1837, ano da renúncia de Diogo Antônio Feijó em favor de Pedro de Araújo Lima e do início do Regresso, várias rebeliões eclodiram em diferentes províncias, como a Cabanagem, no Pará, e Sabinada, na Bahia, e a Farroupilha, no Rio Grande do Sul. O incremento da importância política das províncias fez-se também acompanhar de um acirramento das lutas entre as facções locais pelo controle do poder." (Ferreira, 1999: 32).

${ }^{73}$ Em discurso na Câmara em 9 de agosto de 1837, o então deputado Bernardo Pereira de Vasconcelos, em polêmica com o Ministro da Justiça Francisco Gê Acaiaba de Montezuma (visconde de Jequitinhonha), defende o Regresso - cabe destacar que o regresso era o termo usado para designar a atuação da corrente mais conservadora da elite, que desejava regressar ao sistema de centralização política, reforçando a autoridade central. Esta corrente, que se opunha à política do regente Feijó, acabou vitoriosa com a subida no poder de Pedro de Araújo Lima, futuro marquês de Olinda. "Sr. Presidente, eu não devera entrar em polêmica com um tão distinto orador como o nobre Ministro da Justiça: o silêncio era o partido que mais me convinha: mas, como a justiça e a verdade têm mais força que a retórica,
} 
política e também acabou freando as reformas liberais que vinham ganhando espaço no país. Segundo José Murilo:

A reação não demorou, mediante a instabilidade política do país. Liderada por um antigo liberal, redator do projeto do Ato Adicional, Bernardo Pereira de Vasconcelos, ela começou na Câmara onde se formou o núcleo do futuro Partido Conservador. O regente liberal, Feijó, renunciou em 1837 e foi substituído por um conservador eleito pelo voto popular. A nova Câmara reformou as leis descentralizantes, reduziu o poder das assembléias e dos juízes de paz, criou uma justiça e uma polícia controladas pelo governo central. Em tentativa de parar as reformas, os liberais proclamaram a maioridade prematura do Imperador, em 1840. Mas os conservadores estavam de volta em 1841 e completaram o que se chamou de "regresso" com o estabelecimento do Conselho de Estado. Estava terminada a experiência republicana semifederal. (Carvalho, 1998: 167).

No cenário político mencionado, Tavares Bastos apontou os equívocos que o Regresso trouxe, ao realizar uma comparação equivocada entre Brasil e Estada Unidos, ao apontar os possíveis rumos da sociedade. O equívoco se materializa, pois acreditam que aqui poderíamos caminhar a uma anarquia ao não observarmos os excessos que foram gerados entre os norte-americanos.

Do ponto de vista da influência portuguesa para a gestação de uma concepção liberal no Brasil, é válido lembrar como esse ideário se materializou em em terras lusitanas na primeira metade do século XIX. A partir de 1820, o liberalismo que imperava junto à metrópole era de matiz essencialmente conservador. "Um liberalismo que mantinha a dependência do Brasil, que não identificava o domínio exercido pelos ingleses, que impunha apenas as condições limitativas à autoridade real, não era verdadeiramente senão moderado e contido". (Rodrigues, 1975: 31).

José Honório se colocava claramente contra essa prática liberal. Para confirmar sua postura, utilizava as ideias de Tavares Bastos e, principalmente, exaltava tal figura como a de um intelectual que versava arduamente para superar os limites impostos pela monarquia portuguesa.

O que distingue Tavares Bastos como ideólogo é a defesa intransigente que fez de muitas ideias, raras vitoriosas em sua vida. O que é vivo e morto em sua

resolvo-me a defender a emenda que ofereci ao orçamento da Justiça, e a desagravar um sistema eminentemente governativo e sábio, o sistema do Regresso, das afrontas que lhe fez o nobre ministro da Justiça." (Vasconcelos, 1999: 225) 
obra? Ele viu vitoriosos seu projeto de abertura do Amazonas ao comércio mundial, embora não tivesse correspondido à expectativa de progresso da região; viu vitoriosa a liberdade de cabotagem, que foi um malogro; combateu o protecionismo à industria nacional, um equívoco causado pela sua integral adesão ao liberalismo econômico, que nem os Estados Unidos, que ele tomou como modelo, adotaram e seguiram; promoveu a ligação direta a vapor entre Brasil e os Estados Unidos, quando estes já eram os maiores compradores no nosso café, o que foi uma vitória; combateu a escravidão e viu apenas a Lei do Ventre Livre; defendeu a imigração e o trabalho livre, e não viu a vitória deste; combateu o excessivo conservadorismo, um dos nossos males, invencível até nossos dias; pelejou pela federação e a descentralização, viu-as incorporadas no Programa Republicano de 1870, mas não pode ver os avanços e recuos da ideia; militou pelo sufrágio direto, o voto livre, e não o viu assegurado; advogou, pioneiro solitário da ideia, em 1873, a entrega da apuração eleitoral à Justiça, (...) bateu-se pela divisão territorial e a criação de territórios, alinhou-se entre os defensores de uma nova capital no interior, defendeu a liberdade religiosa, o Estado livre, a Igreja livre; viu a opressão, o terrorismo oficial e a reação, e contra eles investiu sem sucesso; pregou a independência dos poderes, lutou pela proteção das garantias individuais; bateu-se contra o arbítrio do poder e a favor do habeas corpus; denunciou o imperialismo, denominação com que os liberais caracterizavam o absolutismo imperial, exercido através do Poder Moderador; acusou o duplo crime do absolutismo e do colonialismo, tanto o originário como o interno. (Rodrigues, 2002: 76).

O absolutismo português impedia o desenvolvimento de uma mentalidade tipicamente liberal e voltada a uma dinâmica tal qual o liberalismo político clamava. O pensamento de um liberal típico como Tocqueville ${ }^{74}$ não imperava entre nós, além disso, cabe ressaltar que o pensador francês, autor do clássico Democracia na América, com sua ideia de sociedade democrático-federativa, teve, no Brasil, especificamente na figura de Tavares Bastos, um admirador que lutou para que houvesse a base do pensamento tocquevilleano entre nós.

\footnotetext{
${ }^{74}$ Segundo Pierre Manent: "A característica da democracia norte americana prendia-se a poucas palavras: os americanos nasciam iguais, em vez de vir a se-lo. Por conseguinte, a igualdade democrática ali criara instituições políticas que lhe eram adequadas e que já então haviam provado sua flexibilidade e sua estabilidade. Nascido nas townships da Nova Inglaterra, o princípio democrático animava agora uma vasta e próspera nação. O que transcorria na França como um movimento social convulsivo surgia nos Estados Unidos como um conjunto social convulsivo surgia nos Estados Unidos como um conjunto harmonioso de costumes e instituições. (Manent, 1991: 158).
} 
Bastos era contrário àqueles que sustentavam o espírito absolutista das tradições coloniais portuguesas que ainda sobreviviam mesmo após a Independência. Não houve uma ruptura e, apesar do derramamento de sangue, o colonialismo acabou substituindo o absolutismo. "Neste ponto Tavares Bastos se filia ideologicamente ao radicalismo liberal de Salles Torres Homem.” (Rodrigues, 1969). O resultado das medidas apontadas é que éramos não só uma nação "composta de vassalos", mas um conjunto de colônia, onde se agravavam as discórdias provinciais, que tão bem Tavares Bastos expôs em Cartas do Solitário. Fomos vítimas do colonialismo interno, afirmação de José Honório para identificar o tipo de pensamento que ainda imperava no Brasil, mesmo com a emancipação política tendo sido levada a cabo pelo governo.

O liberalismo de Tavares Bastos apresentou-se como fundamental para José Honório, sobretudo, para que esse pudesse fundamentar sua ideia de ordem social e, também, melhor expor a importância da integração territorial e a manutenção da unidade do Brasil. Tendo Tavares Bastos forte inspiração no pensamento de Tocqueville, o político brasileiro teve grande importância para a formação de uma leitura e proposta do sistema liberal. Foi essa preocupação que acompanhou o historiador carioca ao longo de sua escrita sobre a necessidade de instituição de um liberalismo político plenamente organizado no Brasil. Os pontos de inflexão que unem Bastos, Tocqueville e José Honório são certamente os nexos que unem pensadores dispostos a refletir a respeito de possíveis avanços da ordem democrático-liberal.

Se nunca chegou à importância de um Joaquim Nabuco, no que diz respeito ao abolicionismo, Tavares Bastos ganhou vida própria propondo um quadro bastante articulado de reformas modernizadoras. Para ele, a reforma das instituições políticas constituiu na condição indispensável a qualquer programa de modernização política e econômica, ou mesmo de reordenação mais geral do conjunto da sociedade brasileira. O tipo de governo era secundário, ou seja, o que realmente importava era como se organizaria o sistema de poder. Neste sentido, monarquia ou república não se apresentavam como questões fundamentais. Sua maior preocupação era "a questão de centralização/descentralização. O federalismo configurava o eixo que articulava a proposta reformista mais abrangente." Segundo Walquiria G. Domingues Leão Rego:

O federalismo configurava o eixo que articulou a proposta reformista mais abrangente. Por isso, monarquia federativa constituía o horizonte possível, talvez a forma preferencial de regime político. (...) De qualquer modo, o substantivo a ser postulado, a ser realizado, quase como uma panacéia para 
todos os problemas nacionais, era o princípio federativo. Na versão de Tavares Bastos, o princípio federal encerrava virtudes que potencializariam o desenvolvimento de Bastos, o princípio federal encerrava virtudes públicas necessárias à sociedade moderna e civilizada. O "grande modelo" eram os Estados Unidos. No caso de Tavares Bastos, bem como de outros políticos e intelectuais latino-americanos, uma grande influência política e intelectual salta aos olhos: Aléxis de Tocqueville e seu livro senão mais lido, pelo menos mais citado: A democracia na América. (Rego, 1989: 9).

O liberalismo defendido por Honório apontava para a racionalidade da sociedade brasileira. Sua referência aos conciliadores está ancorada nessa problemática, isto é, como seria possível, através da conciliação com os setores subalternos, esperar atitudes que impingissem ao país a possibilidade de desenvolvimento até então inimaginável. O que poderíamos esperar de um José Bonifácio e seu projeto de unidade nacional, de um Tavares Bastos e o seu federalismo; "a liderança conciliadora evitava os excessos, atraía os liberais exaltados, acalmava os radicais e, dessa forma, diminuía o antagonismo social, não renovava o país, não promovia reformas, tornava lento o processo histórico e o progresso minguado não estava de acordo com as possibilidades nacionais." (Rodrigues, 1964: 68).

A conciliação, praticada ao longo do século XIX no Brasil, era a consciência limite da ordem liberal. Reformas expressivas que modificariam o país e tornariam as instituições liberais com um caráter mais próximo ao "americanismo", permitindo, assim, que a sociedade fosse mais integrada e as condições de vida do povo melhoradas de forma satisfatória. A meta dos "conservadores audazes" não encontrava espaço, a resistência da elite política, sempre tendo os seus interesses voltados para a Europa, fora responsável por barrar todo o avanço cívico mais modernizador. José Honório Rodrigues defendia uma conciliação que passou a constituir-se como meta de um grupo diminuto de lideranças:

As alternativas na composição dominante da liderança cruenta correspondem também aos períodos de história cruenta e incruenta, estimulados ou abatidos pelas condições econômicas ou sociais. No processo histórico não só se alternam as lideranças, quer as governamentais, quer as oposicionistas, quer as oficiais, quer as populares, conciliáveis ou inconciliáveis, como surgem os líderes ambivalentes que, como Caramuru, José Bonifácio, Getúlio Vargas, variam de acordo com as condições reais e objetivas. Mas o principal obstáculo 
à real conciliação do Povo com a Liderança, da coexistência pacífica e normal com o Povo com o Poder, foi sempre a desvinculação da liderança com a realidade nacional e o dissídio entre o Poder e a Sociedade. Ambos começaram cedo. (Rodrigues, 1964: 101).

O liberalismo em questão já havia sofrido uma dura crítica em ensaio de Raymundo Faoro, no qual o jurista invoca toda a origem débil do Estado português para insistir que a ideia liberal constitui-se com uma inconsistência exemplar, não tendo forças para alterar a estrutura do Estado e tampouco apresentar condições para este tornar-se um prestador de direitos à sociedade civil, afastando-se, assim, da possibilidade de oferecer melhorias para a vida do povo. Para elucidar como esse afastamento se consolidou, Faoro recorre aos "radicais" e mostra como aquelas ideias, deveriam, necessariamente, ser eliminadas segundo a avaliação de setores "encastelados no poder":

Cipriano Barata e Frei Caneca serão os críticos do processo de desvirtuamento do liberalismo. Cipriano percorre o ciclo liberal completo - 1798, 1817 e 1824. Dá-lhe continuidade com Frei Caneca, que, acorde com o compromisso da Assembléia Constituinte, não aceita a outorga régia, nem o esquema andradino de Estado. Cipriano Barata, um dos deputados às Cortes de Lisboa, percebe que o absolutismo persiste apesar de 22. Em torno da Independência, depois da dissolução da Assembléia Geral Constituinte, governará o Partido Absolutista, percepção que será comum aos liberais da época. Repelem, na sua doutrinação, o liberalismo da restauração, que aqui entrará em revide acoimadatício "conter e dirigir", na sua fórmula de um alto conselheiro de D. João VI. (...) $\mathrm{Na}$ defesa constante do processo que o condenou à morte pela participação na Confederação do Equador, Frei Caneca traça, com clareza, a medula de seu pensamento. Nega que fosse separatista e republicano, mas afirma, de acordo com seus escritos: "A soberania estava nos povos. Os povos não são herança de ninguém. Deus não quer sujeitar milhões de seus filhos ao capricho de um só. Os reis não são emanação da divindade, são autoridades constitucionais. Os povos têm o direito de mudar a forma de governo. Clamando-se ao soberano Congresso sobre alguma lei, que dele emanar, a qual contrária seja aos interesses dos povos, se estes não forem atendidos, desfeito está o pacto: cabenos então assumir nossos direitos. (Faoro, 1994: 71). 
Esse radicalismo, que tem suas origens no liberalismo europeu e norte americano, não encontrava condições de germinar junto às terras do Estado brasileiro ${ }^{75}$. Mantendo com o poder uma relação "sediciosa", sem poder exercer o controle necessário sobre o Estado, a elite proprietária colocou em prática uma política que era aceitável aos setores conservadores. Essa particularidade está na base do "pensamento político brasileiro", o que acabou custando ao Brasil, nas palavras de Faoro: "a impossibilidade de desenvolvimento, adequação do pensar ao fazer. Melhor: de incorporar ao fazer o pensar." (Faoro, 1994: 72).

A amplitude das avaliações de José Honório e seu forte apelo ao argumento liberal defendido por Tavares Bastos demonstram uma particularidade na procura de uma reflexão sobre a condição de desenvolvimento da sociedade brasileira e também como poderíamos ter um liberalismo que fosse mais condizente aos interesses legítimos do povo brasileiro.

Em A Província, obra de Tavares Bastos publicada em 1870, suas teorizações anteriores, principalmente em Males do Presente, são trabalhadas de forma mais técnica e precisa, na tentativa de sistematizar os argumentos apresentados anteriormente. As leituras mais clássicas de A Província dão ênfase ao aspecto da descentralização e do apreço demonstrado pelo autor em relação aos Estados Unidos. Quanto ao primeiro item, é inegável que Bastos ressalta a descentralização administrativa do país. Entretanto, torna-se crasso lembrar que este tema já aparece em Males do Presente, sendo também recorrente em outras obras do autor.

Tavares Bastos discute a descentralização por meio, por exemplo, da crítica à burocracia excessiva que emperra o andamento correto do setor administrativo do país, sendo que nela reside a necessidade do poder centralizado criar mecanismos rigidamente hierarquizados e extensos, sem os quais não consegue gerir a si mesma. $\mathrm{O}$ resultado produz a quebra dos princípios que devem reger o Estado, isso ocorre porque

\footnotetext{
${ }^{75}$ O filosofo italiano Domenico Losurdo traça o perfil da formação do radicalismo liberal nos Estados Unidos e na Europa, quando os desdobramentos das revoluções do século XVIII introduzem formas de governo em que, partindo da premissa lockeana de direito, a propriedade é a base para o direito à cidadania e às novas condições de ação política, mostrando os limites da prática escravista, segundo o autor da Contra história do liberalismo: "Mesmo quando critica a escravidão, a tradição liberal não coloca em discussão a identificação do Ocidente com a civilização do mundo colonial com a barbárie. È diferente a posição do radicalismo, que localiza e denuncia a barbárie em primeiro lugar nos responsáveis e nos cúmplices daquela que é a mais macroscópica violação dos direitos e da dignidade do homem. Herdeiros do radicalismo podem ser considerados Marx e Engels. Para o primeiro em particular, não é apenas epistemológica e politicamente arbitrário ignorar a realidade político-social das colônias, mas é justamente daqui que é necessário partir para compreender, como veremos, a "barbárie" da sociedade burguesa." (Losurdo, 2005: 182).
} 
“... é por meio do país oficial, com os recursos oficiais, que o governo domina o sufrágio e subjuga o parlamento". (Bastos, 1975: 21). Responsável pelas verbas públicas, através do pareceres do Conselho de Estado, a forma de organização política conduzida pelo Estado brasileiro proíbe que haja uma regulação sobre o modo de realização de obras públicas, declarando que não podem lançar imposto pessoal de prestação de serviços ainda quando é esse imposto decretado para um fim municipal. "Ora, contestam o direito com que se criaram inspeções do algodão e do açúcar; sendo, aliás, evidente que se trata de interesses locais, embora tais inspeções pareçam escusadas e onerosas." (Bastos, 1975: 188).

Mas é a admiração ao sistema político instituído nos Estados Unidos da América e a tentativa de introduzir uma prática que fosse similar no Brasil que representara a preocupação, se não central, ao menos fundamental, para o melhor entendimento da ordem liberal entre nós. Na apresentação de Males do presente, José Honório identifica o pensamento liberal de Tavares Bastos da seguinte maneira:

Suas primeiras emendas revelam sua filiação à ideologia do liberalismo econômico, que foi o melhor instrumento de penetração imperialista e de dependência, ainda que informal. Abertura do Amazonas, navegação a vapor para os Estados Unidos (1862 e 1865), a graça de uma subvenção anual à companhia ou empresário que contratasse com o governo dos Estados Unidos uma linha mensal de navegação a vapor, a garantia de um juro limitado, com privilégio exclusivo, aos capitais da empresa que estabelecesse no Império uma linha de comunicação pela telegrafia elétrica (1864), a permissão aos navios estrangeiros do serviço de transporte costeiros, o projeto de casamento civil para contraentes de religiões diferentes, e a diferente era a protestante, a simplificação da carta de naturalização aos estrangeiros, as várias facilidades (contratos de parceria, terras devolutas) que criou com o fim de facilitar a emigração anglo-americana. (Rodrigues, 1976: 10).

É esse espírito progressista que vislumbra uma dinâmica à sociedade brasileira similar aos melhores exemplos do liberalismo que contagiou aqueles que acreditam em sua amplitude política. Ressalva-se, porém, que o entusiasmo com os Estados Unidos tem sua caracterização específica. Tavares Bastos entende que os norte americanos conseguiram resolver a contento o problema da descentralização administrativa e que determinados argumentos podem ser incorporados nos mais 
diversos países que almejam abdicar da centralização, independente de sua história particular.

Da mesma forma que centralizar a administração pode ser positivo em alguns países, José Honório Rodrigues acredita que esse pode ser o caso do Brasil. A descentralização norte-americana é vista como o resultado de uma experiência positiva e que poderia estimular outros países a correrem o risco de tal empreitada, não pela pura e simples adoção integral de todas as práticas político-administrativas dos Estados Unidos, mas sim, verificando cuidadosamente sua aplicação.

Do mesmo modo, o próprio Tavares Bastos já havia discutido, em Males do Presente, que o modelo norte-americano era fruto de uma experiência positiva, de um processo que produzira tanto a federação dos estados quanto o espírito público nos membros daquela sociedade. Dessa forma, a aplicação de um modelo político, que está intimamente vinculado ao desenvolvimento histórico da sociedade, não poderia ser feita indistintamente; seria necessário sobrepor o resultado empírico de um país a outro. "A dificuldade de encontrarmos resultados positivos, sem levarmos em consideração se o outro também possui uma História com resultados empíricos e que, boa ou má, foi ela que construiu os valores que tornaram possível a coesão social.” (Silva, 2005: 167). Assim, o caminho certo para a superação do atraso seria o americanismo ${ }^{76} \mathrm{em}$ sua versão adaptada às condições típicas do Brasil, propiciando, destarte, a criação de elementos para a superação dos entraves historicamente limitantes a nossa tradição social.

\section{4 - História Cruenta: a ocultação dos movimentos sociais no Brasil}

\footnotetext{
${ }^{76}$ Acreditamos que mesmo identificando no americanismo uma forma de maior dinamização do Estado no Brasil, este não representa a experiência que poderia superar os entraves do atraso na sociedade brasileira, Luiz W. Vianna argumenta a respeito: “(...) Mas o americanismo como uma reforma política vinda de cima se apresentava como uma contradição em seus próprios termos. A via americana dependia de dois fatores elementares: terra e mercado de trabalho livres. No entanto, os dois valores que queriam conservar, a unidade nacional e o controle social das classes subalternas, eram sustentadas pelo iberismo, a partir de instituições como o exclusivo agrário e o trabalho escravo. A partir dos anos 40, o Império inicia o silenciamento do Brasil profundo, abolindo as circunstâncias que, na década anterior, permitiram o americanismo, depois do grande medo das revoltas do período da Regência, abdica de qualquer intenção de revolver o país profundo, constituindo-se numa ideologia especial de liberalismo de Estado. Óbvio o suposto de que admite uma larga autonomia para esta agência - sede, por excelência, dos ideias civilizatórios diante do barbarismo da estrutura social - quando opta por uma estratégia de persuasão das elites do Estado a um projeto de longo prazo que vise a induzir a americanização. (...) Exemplo disto é a política de imigração, com a qual se pretende começar um processo de transformações moleculares que redefina, a cultura cívica e o sistema de valores que orientava o país. (Werneck Vianna, 1997: 165).
} 
Com a denúncia do caráter conciliador das lideranças políticas no Brasil, José Honório traça um perfil da prática que a elite oligárquica assume ao longo da História. Segundo suas assertivas, esta elite não procura melhorar e dinamizar a sociedade brasileira, somente permite uma participação secundária do povo. É na avaliação desse complexo processo histórico do país que, na tentativa de maior espaço e melhores condições sociais, o povo sofre com a violência instituída por aquele grupo social. É exatamente nos momentos em que procura maior espaço que a resposta da elite se dá pela violência. Esse é o contexto que José Honório define como "história cruenta".

A ideia de história cruenta retoma uma discussão que o autor se empenha em problematizar desde seus escritos sobre teoria da história, isto é, desde aquele número de obras que versa a respeito da produção historiográfica e sua aplicabilidade dentro de um conjunto de metas. Desse modo, o intelectual já vinha apresentando uma preocupação em mostrar como determinados pensadores estavam empenhados em produzir uma obra que tivesse como premissa ocultar a precariedade do povo ao longo da História. O objeto de estudo eram as "grandes obras, as capitânias hereditárias, os feitos de Portugal” (Rodrigues, 1980). Dessa forma, a conceituação de história cruenta destaca os momentos de "vacilação da elite, que se recusa a atender as reivindicações do povo" (Rodrigues, 1970).

Neste subitem, pretendemos destacar como um conjunto de intelectuais que foram responsáveis em pensar a história do Brasil a partir de um viés "pacífico" e sem grandes "enfrentamentos ou crises sociais", entre esses momentos destacamos a Regência e o processo de abolição. Além disso, observar certa tradição do pensamento social que, sempre pensou as relações sociais do país, sendo um resultado de acordos e processos sem grandes complicações no âmbito político e social. Destarte, pretendemos identificar, ao longo deste subitem, a crítica realizada por José Honório Rodrigues àqueles que afirmaram ser a História do Brasil um movimento incruento, ou seja, uma história tecida sem enfrentamentos, com uma suposta tradição idílica e edulcorada. Essa interpretação colide, com a leitura de história cruenta, que corresponde aos momentos em que o povo foi aviltado e atingido em suas aspirações mais legítimas.

No processo de consolidação de uma proposta política, em sua vertente de maior difusão na sociedade, vinculada às práticas do liberalismo, é comum encontrarmos uma tradição liberal ${ }^{77}$ que, por sua existência aponta os rumos que

77 A discussão a respeito da existência de uma "tradição liberal” nos remete a análise de Losurdo (1997), que versa a respeito da tradição liberal de que Hegel seria, ou não, caudatário. "Neste ponto, em vez de 
levaram à formação de um possível projeto de modernização. Assim, tem-se como intuito analisar os pontos de aproximação ou afastamento da tradição mencionada, além de procurar compreender que tipo de liberalismo era praticado no Brasil.

A respeito das variadas interpretações do liberalismo, Bernardo Ricupero ao explicar o papel que intelectuais como Raymundo Faoro, Wanderley Guilherme dos Santos e Roberto Schwarz tiveram na formulação na elaboração de argumentos a respeito das origens do pensamento político e social brasileiro, faz a seguinte menção:

Apesar das diferentes perspectivas teóricas e políticas, os três, não por acaso, deram grande atenção a alguns temas comuns, em particular, o papel do liberalismo no Brasil do século XIX. Isso ocorre até porque o liberalismo foi, depois da independência, a principal referência ideológica com a qual contavam os brasileiros para criar suas novas instituições, diferentes das colônias. Mas mesmo que Faoro, Schwarz e Santos convirjam para reconhecer a importância do liberalismo no Brasil do século XIX, divergem ao avaliar o significado do que se criou no Brasil a partir dele. (Ricupero, 2007: 32).

Essa divergência entre os três intelectuais, mencionada por Ricupero ${ }^{78}$, retoma a explicação da organização social resultante do processo de independência. $\mathrm{O}$ liberalismo ganha espaço de discussão e acaba sendo incorporado como elemento norteador dos setores oligárquicos. A via para o capitalismo, considerado os limites da ordem liberal que colidiam com os interesses oligárquicos, acabou sendo encaminhada pela tentativa de superação da ordem colonial que não afetasse diretamente os interesses dos grandes proprietários. O caso brasileiro é possível de ser designado como uma via similar ao caso prussiano, levando em consideração a particularidade de um Estado formado a partir de uma condição colonial. Segundo Antonio Carlos Mazzeo:

continuarmos a nos perguntar se Hegel é liberal ou conservador, é preferível estabelecer um confronto direto com a tradição liberal no que diz respeito, por enquanto, à leitura da história e do processo que levou à formação do mundo moderno. Veremos que, mesmo nos pontos de mais radical afastamento daquela tradição, é bem difícil aproximar as posições de Hegel das dos ambientes conservadores ou reacionários." (Losurdo, 1997: 78).

${ }^{78}$ Cabe destacar a explicação de Ricupero a respeito: "Em termo amplos, problemas como a existência de um pensamento político brasileiro estão, como o próprio Faoro indica, relacionados com a presença de um quadro cultural autônomo e, naturalmente, de uma sociedade capaz de moldá-la. Wanderley Guilherme dos Santos lembra que o desenvolvimento das ciências sociais no Brasil, e de todo pensamento em qualquer parte do mundo, segue dois influxos básicos: o proporcionado pela influência de sua evolução em outros centros e o resultante de avanços e recuos no interior da sociedade analisada. Mesmo reconhecendo essa verdade, teremos que partir, no nosso caso, de uma situação em que se era colônia e, portanto, onde, como insiste Schwarz, se faz uso de ideias originalmente produzidas nas metrópoles. (Ricupero, 2007: 32). 
O processo de Estado nacional é excludente para as massas no Brasil. No caso brasileiro a melhor conceituação, pois essa é a que mais expressa sua geneticidade, porque respeita a legalidade histórica de sua condição colonial e, ao mesmo tempo, considera a configuração hipertardia - segundo a definição de J. Chasin - e agrária do processo de acumulação e posterior industrialização do Brasil. (Mazzeo, 1989: 119).

É nesse contexto de uma sociedade em que o desenvolvimento se estabelece de forma hipertardia e que a elite toma medidas de cunho violento contra o povo, que tal prática visa à manutenção de uma ordem social pré-determinada e granítica. Na avaliação de José Honório, essa atitude visava à continuidade dos interesses desse grupo em detrimento da maioria da população brasileira. A prática usual dessa elite é o temor à conspiração e a qualquer movimento que advoga aos setores subalternos a possibilidade de uma sociedade reformada e modernizadora, algo que colida, portanto, com interesses do setor proprietário. Segundo José Honório:

A concepção conspiratória da História tem no Brasil, origens liberais. Foi uma deformação ideológica, só ultimamente caracterizada e agravada, pois não temos, infelizmente, tradição liberal na forma euro-americana e as próprias campanhas liberais só defendiam aspirações reduzidas da classe média e das elites dissidentes. Essa concepção se contrapunha ao mesmo tempo à ideia de que a História era uma aliada da vitória inevitável das forças de esquerda. (...) Talvez outros acreditem também que a História esteja aliada ao avanço mais ou menos radical, mas as forças de direita, estas realmente descrêem e conspiram para que seja sua a vitória. As conspirações visam a interromper o processo normal da vitória majoritária, especialmente depois das derrotas nas urnas, cujo veredicto jamais aceitam, culpando o povo de imaturidade pela escolha. A concepção conspiratória é intervencionista, ativista, intromete-se no processo para deturpá-lo ou desviá-lo do curso que lhe parece adverso. E assim o processo histórico brasileiro tem sido anormalizado pela intervenção de forças minoritárias, especialmente depois do agravamento do desequilíbrio entre as aspirações populares e as instituições arcaicas. (Rodrigues, 1965: 12).

A concepção conspiratória da história tem uma tradição presa a formas que limitam as mudanças na interpretação da sociedade brasileira. Sendo assim, estávamos impossibilitados em superar um conjunto de problemas que foram gestados 
ao longo de uma tradição "conservadora e anti-povo" (Rodrigues, 1965). No intuito de apontar, quais foram os limites do pensamento associado à interpretação "conspiratória" da sociedade brasileira entendendo-a como resultado de uma proposta conservadora, José Honório teceu os seguintes comentários:

(...) Na verdade, o domínio conservador das minorias foi sempre tão grande e contínuo que as classes médias e trabalhadoras, escravas primeiro e livres depois, revelaram sempre uma deferência, um respeito, um acatamento para com seus superiores, que não só amoleceram as lutas de classes, como mantiveram "no seu devido lugar" as classes sociais majoritárias. A deferência favorece o domínio, mantém o tradicionalismo geral e o conservadorismo político. Ele foi um aspecto social e psicossocial originário da fase colonial, que se preservou no Império e vem tendo seu declínio a partir da República. (1988: XXXV).

Desse modo é que se configura um aspecto político voltado às colisões e enfrentamentos entre aqueles que propõem um desenvolvimento da sociedade e, dessa forma, visam uma maior preocupação com os setores minoritários. Todavia, o processo histórico brasileiro compõe-se mais de instantes de retardamento que de instantes de aceleração e a liderança tem sido mais dominadora que criadora. A metamorfose pode ainda demorar, "embora o prazo histórico esteja se esgotando" (Rodrigues, 1965). A análise honoriana esta preocupada em identificar os retardos dessa tradição liberal, não existiram momentos de aceleração para os interesses do povo, e menos ainda formação de práticas que visavam melhorar a vida do povo.

A história cruenta é a tônica de um país em que as lideranças políticas foram, cada vez mais, se afastando do povo para manter os seus interesses. Nesse sentido, iremos destacar quais foram esses momentos, ao longo de nossa tradição política, os instantes de ação cruenta contra o povo e como alguns pensadores, tentaram esconder esse lado violento do liberalismo na sociedade brasileira.

A história do Brasil não é uma história francamente cruenta, é impossível negar o caráter sangrento com que se processou muitas vezes o domínio das grandes massas escravas ou escravizadas. Devem-se contar ainda as grandes fomes, as grandes epidemias, e as endemias que grassaram sempre e tornaram ensangüentado o processo histórico brasileiro. A linha conciliatória ocorreu muitas vezes e moderou a violência do processo; outras vezes, "a submissão, a paciência, a omissão de um lado, e o temor, a necessidade e o poder 
promoveram os acordos tácitos que não diminuem as distâncias, mas permitem baixar as tensões sociais." (Rodrigues, 182: 108).

\section{5 - Rebeliões regenciais: História cruentissima}

Na sociedade brasileira, com todas as suas deformidades sociais e crimes contra os interesses legítimos da maioria subalterna, nunca uma revolução foi vitoriosa. Houve rebeliões populares e sociais, como a Balaiada, a Cabanagem, a Praieira; houve banditismo social, rebeliões negras, Canudos, o Contestado, mas a população sempre foi reprimida e esmagada pelas forças "legalistas" e nas reivindicações apenas conseguiram pequenas concessões. Segundo José Honório, efeito diferente foi o das rebeliões que representavam as forças e aspirações das classes dominantes:

As rebeliões das classes dominantes, como a liberal de 1841, os Farrapos de 1835-1845, levaram o poder a fazer concessões de caráter político. O poder, como um círculo de ferro, estendia-se para permitir que outro líder revelado pelo outro lado, no mesmo nível social, entrasse para o grupo dominante. Foram essas liberdades de trânsito político, foram às tolerâncias, foram às pequenas doações aos grupos sociais maiores e mais cheios de reivindicações que permitiram uma relativa paz durante alguns períodos da história brasileira, mais no Império que na República. A conciliação foi o grande instrumento político, tal como a moderação, e nisso distinguiram fluminenses, mineiros e baianos, os políticos que tiveram sempre diante de si, cheias de queixas e aspirações, as massas negras, mas mais sofridas de todas. (Rodrigues, 1982: 111).

Nesse ínterim, segundo as assertivas de José Honório, a condição da maior parte do povo sempre foi de opressão, conseguindo, em raros momentos, contar com uma prática política que atendesse às suas necessidades básicas e "aspiração liberticida". Os momentos de retardo e de avanço ficaram, na sua grande maioria, a cargo de medidas adotadas por lideranças políticas, tal como revela a avaliação realizada pelo intelectual carioca.

Com relação ao próprio cenário histórico, esse ganha ares "cruentos" a partir do processo que desembocou na abdicação do Imperador. Assim cabe ressaltar que no dia 7 de abril de 1831, D. Pedro I resolve abdicar do trono brasileiro medida vista como contraditória tal iniciativa colocou o país nos difíceis anos da Regência 
(1831-1840). O modelo político adotado era uma forma constitucional de solucionar o problema instituído com a abdicação, pois na época o príncipe herdeiro não tinha idade legal para assumir o trono, contava então com apenas 5 anos. A solução estava, portanto, em nomear três regentes, segundo a Constituição vigente. Todavia, pelo fato de que o Congresso estava em recesso, o partido moderado assumiu o poder com o intuito de frear as agitações políticas da época. Inicialmente, o governo de Nicolau Pereira de Campos Vergueiro, José Joaquim Carneiro de Campos e Francisco de Lima e Silva reintegraram o chamado "ministério dos brasileiros" e anistiou os presos políticos $^{79}$.

As opiniões de intelectuais a respeito do período são as mais variadas. Para o autor de Teoria da História do Brasil, o período regencial representa um momento da "história cruentíssima", pois os movimentos que apresentavam o povo como base sucumbiram, bem como não foram atendidas as reivindicações legítimas das massas. Somente movimentos com caráter liberal e pequena participação popular não foram eliminados violentamente por parte das lideranças oficiais. Os que discutiam, entre outros pontos, o fim da escravidão viu o povo ser massacrado, porém há aqueles intelectuais que apontam uma visão edulcorada do período, pensadores que representam a tradição conservadora apontada por José Honório.

Um bom exemplo dessa análise é a de Oliveira Lima, em seu livro $O$ império brasileiro (1822-1889). Na obra do "historiador da diplomacia do início da República" (Almeida, 2001), o Período Regencial foi obra estratégica de D. Pedro I, homem de "natureza essencialmente generosa" (Lima, 1986: 21). A abdicação em nome de seu filho, nessa perspectiva, foi vista como uma forma de mostrar sua tristeza com o juízo que os brasileiros apresentavam dele, enfim trata-se de um incompreendido, “(...) Prefiro descer do trono com honra a reinar desonrado e aviltado.” (Lima, 1986: 23). Com um crescimento das hostilizações contrárias a sua liderança, D. Pedro viu-se na obrigação de romper com a condição de Imperador e retornar a Portugal, porém, visando eliminar qualquer crise política, supostamente, mais severa, passa a agir com destreza e, seguindo esse raciocínio decide pela abdicação.

\footnotetext{
${ }^{79}$ A respeito da instituição do Regime Regencial como resultado da abdicação de D. Pedro I, Caio Prado Jr tece os seguintes comentários: "Com a abdicação de D. Pedro chega a revolução da Independência ao termo natural de sua evolução: a consolidação do "estado nacional". O primeiro reinado não passara de um período de transição em que a reação portuguesa, apoiada no absolutismo precário do soberano, se conservara no poder. Situação absolutamente instável que se tinha de resolver ou pela vitória da reação a recolonização do país, que várias vezes, como vimos, ameaçou o curso natural da revolução - ou pela consolidação definitiva da autonomia brasileira, noutras palavras, do estado nacional. É este o resultado a que chegamos com a revolta de 7 de abril." (Prado Jr, 2006: 64).
} 
A iniciativa de D. Pedro de se afastar do Rio de Janeiro, tem sua razão por tratar-se do local em que a população, composta em sua grande maioria de pessoas nascidas no Brasil e, portanto, com vínculos fortes a esse país - tanto afetivos como econômicos -, se opunha à continuidade de um governo atrelado a Portugal. Argumentando a respeito do ato, Oliveira Lima afirma:

Logo depois do ato de abdicação redigido e firmado, o que ele fez sozinho no seu escritório, D. Pedro quis partir, embarcar na nau inglesa, surdo a todos os rogos de retardar esse momento definitivo. A muito custo consentiu em aguardar o voto do Parlamento, tomar conhecimento, ainda em território nacional, prestes, portanto, a toda emergência, se o advento de seu filho se efetivara. O encarregado de negócios da França, Pontois, fez apelo ao seu espírito cavalheiroso: "Vossa abdicação, Senhor, foi livre e espontânea. Para dar disto a prova mais evidente, não deveis partir precipitadamente, como um fugitivo. O Imperador soube melhor abdicar do que reinar. No decorrer dessa noite inolvidável para quantos a testemunharam, o soberano elevou-se acima de si próprio e revelou constantemente uma presença de espírito, uma firmeza e uma dignidade notáveis, de modo a patentear o que esse infeliz príncipe teria podido ser com uma melhor educação e se exemplos mais nobres tivessem caído sob seus olhos.” (Pontois apud Lima, 1986: 23).

Já em Portugal, e tendo que equacionar as pendências do trono português resultantes das investidas de seu irmão D. Miguel, o príncipe herdeiro deixa o território nacional e passamos aqui a conviver com o regime Regencial, que, entre outras características, viu o quadro de crise institucional se intensificar e a eclosão de várias revoltas em boa parte do território. As revoltas ocorrem no desmembramento de medidas adotas pelos regentes, principalmente após a mudança de sua organização Trina pela Una em 1835 por meio do Ato Adicional de 1834, que, além disso, fora responsável pelo fim do Conselho de Estado. Com a instalação da Regência Una e a nomeação do Padre Diogo Antônio Feijó ${ }^{80}$ como regente precipitou-se todo um cenário de mudanças na política do país, além da alteração na organização do poder político ${ }^{81}$.

\footnotetext{
${ }^{80}$ Jorge Caldeira, em estudo sobre o Padre Feijó, explica que este fora eleito para ocupar o cargo de Regente Uno, sendo uma personagem que destoava da maioria dos políticos de então: "não pertencia a uma família tradicional, nem era grande proprietário de terras e sem possuir título de nobreza, mesmo assim fora o escolhido." Qual o critério para sua escolha? Ainda segundo Caldeira: "Fora escolhido porque era um homem do Parlamento, um deputado importante. Constituição e Parlamento haviam sido as instituições novas, brasileiras, que se acrescentaram à administração monárquica herdada de Portugal com a fórmula da independência brasileira, comandada pelo herdeiro do trono português. Porém, é vista
} 
Além disso, o 7 de abril não inseriu, como era de esperar, levantes que pudessem instituir o regime Republicano, a "generosidade nacional" que banhava a figura de D. Pedro fez com que o período de transição apresentasse uma continuidade "amplamente democrática" (Lima, 1986: 25). Dessa forma os abalos que ocorreram ao longo da regência repercutiram, de modo nefasto na sociedade exaltando os aspectos mais escusos da prática política, deixando em evidência a quebra do "edifício nacional" que fora construído pelo Imperador.

A abdicação representa a superação de uma importante etapa no processo de consolidação do Estado Nacional. Pelos efeitos que produziu, inaugurou um período de revoltas e agitações promovidas pelo liberalismo radical empurrado para as províncias, não conseguindo, plenamente equacionar a crise que se arrastava durante o primeiro reinado. Nesse sentido, José Honório Rodrigues afirma que: "Com a Regência, quando pela primeira vez se estabeleceu um governo nacional libertado das facções portuguesas que até então comandavam o país, um choque profundo se estabeleceu entre as aspirações populares e a defesa do status quo pela minoria". Assim, abriu-se uma fase em que "acenando com as reformas, sempre concedidas ao mínimo, evitava-se ou pensava-se em evitar a Revolução e o país no seu todo é sacudido por crises, desordens e agitações violentas." (Rodrigues, 1965: 75).

A tendência que se afirma ao longo do período regencial é a de um reajuste conservador no bloco de forças que fizera a Independência e a derrubada do imperador. Resultam daí a contenção do radicalismo e a reafirmação do poder dos grandes proprietários rurais. Com a eleição de Feijó, é designado para a pasta da Justiça Abreu e Lima, com a intenção explícita de por fim a qualquer agitação que tirasse a sociedade de sua normalidade. As medidas que o período do governo Feijó conseguiu

como uma conquista de todos os brasileiros sobre seu destino. Na época, o Parlamento contava com apenas nove anos de existência. Embora recente, a nova instituição revelou-se de importância crucial. Com apenas cinco anos de funcionamento, o Parlamento foi responsável pela renúncia de D. Pedro I e, desde 1831, era o único centro efetivo de poder político no Brasil. Ser deputado nessas condições, era participar ativamente do destino do país. Do Parlamento saíam as ideias e os homens que então comandavam a construção nacional; Feijó, ao ser eleito, foi considerado o melhor deles. A maioria dos outros nomes lembrados na eleição também eram parlamentares, mas Feijó pareceu ter ideias melhores sobre o futuro do país." (Caldeira, 1999: 12).

${ }^{81}$ Em estudo de fôlego a respeito da centralização e descentralização no Império, Gabriela Nunes Ferreira expõe que: "Em agosto de 1834, o Ato Adicional veio dar novo contorno à organização política e administrativa do Império. Pela nova lei, aboliu-se o Conselho de Estado e estabeleceu-se a Regência Una, eletiva e temporária. As províncias ganharam vida nova, não mais como simples unidades administrativas, mas sim políticas, com significativa margem de autonomia - muito embora se tenha mantido a nomeação dos presidentes de província pelo imperador. Os Conselhos Gerais das províncias foram abolidos e substituídos pelas Assembléias Legislativas Provinciais, com amplas atribuições." (Ferreira, 1999: 29). 
colocar em prática fez com que as lideranças radicais fossem desestruturadas e sua atuação perdesse o impacto na estrutura monárquico-escravista que vivíamos.

A Regência foi uma época de crises políticas que ameaçaram derruir todo o edifício nacional e que a reação era uma necessidade por tal forma arraigada no espírito de quantos tinham responsabilidade de governo, que o que fez a grande reputação dos homens do Estado desse período não foi o que eles realizaram em favor do liberalismo, mas a resistência que opuseram à anarquia (grifo nosso). Os anos imediatos à abdicação foram os anos de luta entre os três ideais - o ideal tradicional, cada vez mais esvaecido: o ideal revolucionário, cada dia mais desacreditado, e o ideal de autoridade combinado com o espírito liberal, que foi o vencedor no Império porque se fundiu com o primeiro. Foi o tempo das sociedades patrióticas de todos os matizes. (Lima, 1986: 27).

Por conseguinte, o contexto político que ganha espaço e consolida-se durante os anos da regência explica, em grande medida, a eclosão das revoltas que assolaram o país. Por mais que representassem movimentos de caráter local, expressam o "ideal revolucionário", que, mesmo desacreditado, reivindicavam mudanças expressivas no mando e controle político do país. Além disso, não aceitavam que os Regentes, de acordo com suas atribuições, não tivessem como meta somente a defesa do “edifício nacional", mas que pudessem oferecer ao povo melhorias substancias. (Wernet, 1984).

Assim, com a assinatura do "Ato Adicional" em 1834, instalou-se um processo de "ultraliberalização" do país, por meio de medidas que eram criticadas pela população, refletindo, portanto, na ebulição de vários movimentos revoltosos. Tal cenário levou o regente a ser denominado de "Cavaignac de Batina" (Lima, 1986:26). O certo é que a partir de 1835 houve um crescimento na descentralização do poder, isso principalmente por meio das assembléias locais, e a superação do conselho do Estado, dessa forma, o movimento revolucionário mais grave a que Império teve que combater foi a Guerra dos Farrapos - Revolução Farroupilha ${ }^{82}$-, pois propunha a emancipação política da região sul com a criação da República Piratini.

\footnotetext{
${ }^{82}$ A Revolução Farroupilha, também conhecida como Guerra dos Farrapos, eclodiu no extremo sul do país, Rio Grande do Sul e foi a expressão do descontentamento riograndense com determinadas medidas econômicas. Os produtos pecuniários do Rio Grande do Sul, em competição direta com Uruguai e Argentina, eram vítimas de uma legislação discriminatória por parte do governo imperial. Além disso, os caudilhos da fronteira sentiram a necessidade de se expandir pelas terras do Uruguai, onde a pastagem era melhor, e queriam garantir a liberdade de movimento de entrada e saída do gado nessa área. A independência uruguaia em 1828 e o desinteresse do Rio de Janeiro pela situação econômica dos
} 
O argumento de Oliveira Lima para identificar esse movimento como o mais grave do Império está pautado em sua interpretação acerca da tentativa de separação e, por se tratar de uma revolta encabeça por estancieiros, revelando, destarte, seu poder de enfrentamento às tropas federais.

O movimento revolucionário mais grave que o Império teve a combater e a suprimir foi o do Rio Grande do Sul, conhecido pela Guerra dos Farrapos e que durou dez anos, de 1835 a 1845. Começou ao tempo da regência Feijó e teve por causa meras rivalidades políticas todas locais. O partido denominado exaltado, que era afinal o liberal, estava no poder; o outro partido denominado moderado, que era afinal o conservador, estava na oposição. A eleição da assembléia legislativa criada em virtude do Ato Adicional deu a vitória aos moderados: a facção contrária, contando com a proteção do poder central, isto é, da Regência, não se quis sujeitar ao resultado do sufrágio e pegou em armas, os elementos paisanos, secundados por certos elementos militares. Se as paixões reinavam na política, é sabido que a disciplina não reinava no exercício. $\mathrm{O}$ vicepresidente em exercício teve de deixar Porto Alegre, a capital da província, e instalou-se no Rio Grande, enquanto que o presidente rebelde, aclamado tomava seu lugar e entrava em funções, apoiado por uma assembléia legislativa composta da minoria eleita e de suplentes convocados para preencher o número legal. (Lima, 1986: 25).

Toda a argumentação mencionada refere-se à análise que Oliveira Lima faz da Revolta dos Farrapos e do modo como evidencia que essa foi tratada, ou seja, como sendo a "principal revolta regencial". Cabe destacar que a região já havia sido palco de disputas e enfrentamentos, quando da passagem de sua condição de uma região de controle espanhol para o português ${ }^{83}$, além de expressar uma forte tradição na luta

caudilhos gaúchos, foram fatores que reduziram o fluxo bovino, e, portanto, diminuíram os lucros, retardando a expansão da indústria pecuniária e impedindo-lhes de fazer face à demanda do mercado. Dentro da própria Província havia grupos sociais com interesses econômicos parcialmente antagônicos: de um lado, as elites da região de Laguna, isto é, o setor administrativo da Província, de outro as elites da fronteira, compostas pelos coronéis da pecuniária, na parte meridional da Província. (...) Os chefes dos farrapos, saídos da classe de estancieiros da fronteira, queriam reforçar as instituições da tradicional sociedade riograndense. Seu "republicanismo" não pode ser confundido com um "liberalismo radical". Os farrapos ou farroupilhas, expressão originalmente depreciativa, adotada pelos rebeldes e usada no sentido de camarada, não eram revolucionários sociais empenhados em reestruturar a sociedade. (Wernet, 1984: 49).

${ }^{83}$ A esse respeito ver a obra de José Honório Rodrigues que retrata a formação do Estado do Rio Grande do Sul. Em tal livro o historiador carioca afirma: "A disputa do Rio Grande com os espanhóis quer encarar a parte diplomática que resulta da assinatura do tratado de 1750 e da obra da demarcação, não seus efeitos sobre os limites, mas nas consequências sociais do conhecimento e exploração da região, a tradição de enfrentamento e disputa resultou no Tratado de Madri de 1750" (Rodrigues, 1986b: 56). 
política do país ${ }^{84}$ com lideranças que procuravam conciliar-se com o povo. Dessa forma, a região do Rio Grande do Sul já apresentava um histórico social de "lutas fratricidas" 85 , porém, o que mais repercute quando se trata do movimento de Farrapos, é que ele não expressa o movimento de caráter popular e cruento do período regencial, não é através desse movimento que podemos identificar o quanto o povo foi "capado e sangrado", dessa forma o que nos parece claro é que as escolhas de Oliveira Lima. Assim, em outras palavras, seu posicionamento ideológico, pauta-se em discorrer a respeito dos ganhos instituídos pela "herança de D. Pedro" e mais ainda, em não dar espaço e trazer à tona a versão que aponta o quanto nossa história foi cruenta. Seu posicionamento conservador, no sentido de Mannheim ${ }^{86}$, posiciona o autor de $O$ império brasileiro entre os representantes de um pensamento defensor da História Incruenta.

Por sua vez, quando José Honório discute o movimento regencial duas questões são as que merecem maior atenção do intelectual carioca: a ação política das lideranças do período e a violência da revoltas regenciais. É fundamental destacar que com a Regência houve um "choque profundo que se estabeleceu entre as aspirações nacionais". Falava-se muito em reformas, porém, não foi realizada nenhuma que pudesse ser considerada expressiva durante os anos de 1831-1840, isso porque, "as oligarquias em seu apego às estruturas arcaicas e coloniais e aos seus privilégios intocáveis, foram sempre contra as reformas, inclusive as constitucionais." (Rodrigues, 1966: 42).

Definindo o período como de uma história cruentíssima, o intelectual carioca avalia como as lideranças políticas, pautadas pela estrutura do Império,

\footnotetext{
${ }^{84}$ José Honório aponta na introdução da obra $O$ continente do Rio Grande, que a região é um celeiro de lideranças políticas conciliadoras com o povo, cabe destacar que o livro é de 1953 , período do $2^{\circ}$ mandato de Getúlio Vargas.

${ }^{85}$ A respeito da formação da propriedade na região do "Rio Grande", levando-se em conta a particularidade das relações da propriedade fundiária, o sociólogo Fernando Henrique Cardoso argumenta que: "Os militares, gaúchos enfim, obtiveram a cessão das terras com um beneficio distribuído em nome da Coroa pelos comandantes, governadores e capitães-generais, para que as explorassem e dela se usassem no seu proveito e real interesse através da única maneira de manter o latifúndio: a exploração da mão-de-obra disponível, isto é, dos não proprietários e dos escravos. Desde o século XVIII, portanto, criava-se com a grande propriedade o que era inevitável em termos das condições de organização do poder e trabalho então possíveis: uma sociedade estruturada radicalmente." (Cardoso, 2003: 118).

86 A instituição de um pensamento conservador é fruto das próprias particularidades que o desenvolvimento social segue no Brasil. A respeito Karl Mannheim argumenta que: "O surgimento de um movimento conservador consciente já é, portanto, uma indicação de que o mundo intelectual e social moderno desenvolveu uma estrutura particular própria. A mera existência do conservantismo como uma tendência coerente significa que a história está desenvolvendo-se cada vez mais nos termos da interação de tais "tendências" e "movimentos" abrangentes, alguns dos quais são "progressistas" e estimulam a mudança social, enquanto outros são "reacionários" e a retardam." (Mannheim, 1986: 113).
} 
poderiam oferecer uma mudança substantiva ao país. Permitindo somente as pequenas reformas, a ideia fixa era de evitar revoluções:

Se existe um pensamento comum que ligue os homens que sustentam a administração atual é o de obstar a uma revolução violenta que traria a desgraça ao Brasil. Este é o pensamento dos membros dessa Câmara, a cujos complexos se tem dado o título de maioria, que procuram sustentar a regência e o governo, como o resultado legal do voto da Assembléia e da Constituição, contra os atentados das diversas facções extremas, que por tantos meios tem procurado derrubá-la. Nós somos revolucionários. Disse-me que a Regência parece querer a reforma já e já. A Reforma já é um voto exagerado de alguns espíritos imprudentes, derramados na superfície do Brasil e de que podem provir-nos os maiores danos; declarar que o governo fomenta este espírito anima esse voto, é declarar que ele esta à frente de quase todas as revoluções sanguinárias que têm aparecido ou possam aparecer nas diversas províncias; é fazer-lhe uma das imputações mais odiosas que podem ser-lhe dirigidas. (...) De certo, entre nós mesmos, aqueles que julgam as reformas necessárias à felicidade do Brasil, não querem nem mais nem menos do que a constituição, porque ela autoriza essas reformas. Se acaso são prudentes, se convêm na época atual, a questão é outra, mas não se deixa de querer a constituição, votando-se a favor de reformas que a constituição consentiu. (Rodrigues, 1988: 125).

É inquestionável que entre as lideranças políticas, - e por isso José Honório Rodrigues sempre aponta para o caráter anti-reformador dessas lideranças não havia o mínimo interesse que passássemos pela mudança necessária que poderia fazer de nós uma Nação mais consequente, com relação às condições sociais. Ao contrário, todos aqueles que se lançavam a essa tarefa foram repudiados pelo poder constituído e refutados na sua ação política. As lideranças políticas são refratárias, débeis e, portanto, não conseguiram assumir o compromisso de rompimento com a tradição. A obra honoriana, nesse sentido, se opõe à análise de Oliveira Lima, pois, como já apontamos, para o primeiro, o problema mais premente durante a regência é o resultado da forma de ação de nossas lideranças políticas que, ao invés de realizar reformas substanciais, segue atrelada ao continuísmo do Império e quando realiza alguma reforma de fato, essa surge com a notória intenção de limitar as legítimas aspirações do povo. 
Para Oliveira Lima, por sua vez, tal período é entendido como de transitoriedade para a Maioridade e sua efetivação é tida como fruto de uma arguta medida adotada pelo Imperador D. Pedro. Assim, a característica principal de não atender as reivindicações do povo não é levada em consideração, assim como não há preocupação com os fatos cruentos que se sucederam.

$\mathrm{O}$ intelectual carioca encontra-se nas antípodas do que propunha Oliveira Lima. Para Rodrigues, as Revoltas Regências foram momentos cruentíssimos na História do Brasil. Nesse sentido, sempre alvejado em seus interesses, o povo foi como nunca "capado e sangrado" sem ter suas mais legítimas aspirações atendidas. Pior que isso é que foi durante as revoltas que mais próximo chegamos de acontecimentos que expressavam a possível ascensão e mudança da condição dos setores subalternos. Durante a Regência, as lideranças inconciliáveis levaram ao "encharcamento do solo de sangue" (Rodrigues, 1966: 43).

As rebeliões e revoltas não eram a Revolução, e embora corresse rios de sangue, a verdade é que não se fizeram as reformas, não se permitiu a participação maior do povo no processo político, não se cuidou do seu bemestar, nem se promoveu o desenvolvimento nacional, nutrido a xarope de dormideira, tal qual fizera a minoria retardatária portuguesa, lenta ou sonolentamente. Até esse momento, a conciliação não se tornara o instrumento política que procuraria evitar os rios de sangue e que abafaria as rebeldias e conteria o espírito de reforma. (Rodrigues, 1966: 52).

Entre as Revoltas, ao versar sobre a de Farrapos, isto é, aquela que Oliveira Lima classificou como a de maior expressão, José Honório Rodrigues ressalta que se tratou de um movimento diferente, haja vista que o povo não se manifestou diretamente frente à contenda. Mais que isso, ressalta que a participação foi inexpressiva, sobretudo no que diz respeito as reivindicações e à defesa de interesses. Em outras palavras o caráter foi majoritariamente político e não social. Em consequência, destaca que as revoluções que representavam, em suas propostas e reivindicações, maior perigo às instituições devido a seu caráter social foram abafadas e reprimidas com muito derramamento de sangue. Antes de lançar uma possível proposta conciliadora, as lideranças regenciais souberam muito bem distinguir uma da outra e lançaram as mais nefastas formas de repressão.

A diferença fundamental entre o levante do Rio Grande do Sul é que o movimento contava com tropas regulares e chefes que, entre outras, incomodavam diretamente a monarquia. A forma de trato, por parte daqueles que representavam o 
poder político no Brasil, expressava "homens querendo romper com a monarquia" (Rodrigues, 1966: 54). A qualificação dada aos participantes da Revolução Farroupilha difere-se, e muito, dos outros levantes. Ali o elemento primordial era a ruptura territorial, porém os setores sociais envolvidos não colocavam em xeque a estrutura da sociedade. Logo, o enfrentamento ocorreu entre setores que compunham a sociedade estancieira no Rio Grande do Sul, representando uma contenda de frações do próprio exército. Uma Revolução cujo desfecho representa a sua inoperância quanto à desestabilização do regime, ou mesmo, a possibilidade de melhorias sociais de calibre maior. “(...) Os revolucionários da Farroupilha, em 1845, foram todos anistiados, todos isentos do serviço militar, honrados em seus postos." (Rodrigues, 1966: 50). Dessa forma, não será nessa manifestação que teremos a forma mais cruenta de enfrentamento, muito menos, como afirmava Oliveira Lima, a revolta de maior importância do período.

A leitura de José Honório Rodrigues em relação às revoltas regenciais foge àquela proposta por Oliveira Lima. $\mathrm{O}$ intelectual carioca avalia que durante as contendas regenciais investidas sempre foram de grande violência, pois foram manifestações de teor político contundente e de grande significado, pois houve uma expressiva participação popular que incomodava os responsáveis pelo Estado. O que devemos deixar claro é que as revoltas foram consequência das condições sociais existentes no Brasil. Nesse sentido, o governo do Padre Diogo Antônio Feijó, dentro de quadro de lideranças regenciais, foi o que mais sofreu com a eclosão de movimentos que desestabilizaram a ordem política e social do país. Tal período, portanto, figura como o momento que a história cruenta domina o cenário político à época da Regência.

Feijó, Ministro da Justiça e Regente, enérgico e autoritário, não foi conciliador. Foi rigoroso e inflexível, persuadido, segundo suas próprias palavras, "de que em todo o tempo, e principalmente nos convulsivos, só a firmeza de conduta, a energia e a justiça podem sustentar o governo". Foi duro, fechado, impermeável, e logo 5 dias depois de sua posse (5 de julho de 1831) enfrentou uma sedição militar no Rio de Janeiro, felizmente incruenta, mas criadora de pânico e terror. (...) Feijó sabia que o descontentamento e o desespero público haviam atingido ao máximo, quando, em 16 de maio de 1832, ainda Ministro da Justiça, confessava que as comoções abalavam todo o Império, desde o Pará ao Mato Grosso, com três "revoluções" em Pernambuco, roubos, massacres, incêndios, e outras tantas na Bahia. (Rodrigues, 1966: 44). 
Na condição de Ministro da Justiça, o Padre Feijó já dava indícios do tipo de liderança que colocaria em prática como regente. A eclosão de boa parcela das revoltas ocorreu justamente no período de sua regência. ${ }^{87} \mathrm{~A}$ rearticulação das correntes políticas $^{88}$ fez com que Feijó encontrasse, logo de início, a oposição em maioria no Parlamento. A esquerda liberal - no caso os integrantes do Partido Exaltado - já havia sido aniquilada em grande parte sem maioria parlamentar acabou interpretando aquele estágio político como uma experiência republicana aos moldes do presidencialismo norte-americano, sem se preocupar, portanto, em organizar politicamente as dificuldades que se levantaram na Câmara. A condição tendeu a desestabilizar-se de forma definitiva, quando, de modo mais intenso, isto é, a partir de 1835, as revoltas regenciais começam a ganhar um ritmo mais expressivo de eclosão.

A conjuntura política tornou-se insustentável e inicio-se um conjunto de revoltas fratricidas e cruentas. As agitações populares ocorreram em todo o país. Neste sentido, a introdução de uma História Cruenta ganhou espaço e passou a caracterizar decisivamente o período. Entretanto, poucos que procuraram recuperar os anos da regência levam essa premissa em consideração, mas para Honório não há dúvida de que tais revoltas sociais "banharam de sangue o país” (Rodrigues, 1966).

O povo encontrava-se em estado de inconformismo generalizado, motivado por fatores sociais e econômicos, pois continuava, segundo José Honório, como "besta de carga". Os nove anos de 1831 a 1840 foram anos de muito sangue, maior ainda pela reação extremada contra movimentos de caráter popular e sertanejo, exemplificado por revoltas sociais como os Cabanos $^{89}$, no Pará, e a Balaiada, no

\footnotetext{
${ }^{87}$ Com a situação política de instabilidade com a abdicação: "Coube a Diogo Antônio Feijó, nomeado ministro da Justiça em julho de 1831, a parte mais dura da tarefa. Seria ele o encarregado da manutenção da ordem no país convulsionado. E a maior ameaça à ordem, naquele momento, era a explosiva combinação de um exército imenso sem disciplina e que facilmente dava ouvidos a provocadores de plantão. O resultado era uma seqüência ininterrupta de motins, provocados ora por um ora por outro grupo. (Caldeira, 1999: 30).

${ }^{88}$ Os exaltados não tinham força política suficiente para esboçar uma liderança política. Com a morte de D. Pedro, os caramurus - grupo que defendia a volta do Imperador - também se dissolveram. Com a ausência dos extremos - exaltados e caramurus - os moderados, como tendência de centro, não tinham mais função. Sua ala direita, que já não tinha apoiado a candidatura de Feijó, como Bernardo Pereira de Vasconcellos, Honório Hermeto Carneiro, Rodrigues Torres e outros, aproximava-se da opinião política dos antigos caramurus, defendendo um governo forte e centralizado, capaz de fazer frente às rebeliões que agitavam as províncias. Convictos da necessidade de "parar o carro da Revolução" formaram, na Câmara dos Deputados, o bloco dos regressistas, opondo-se aos liberais ou progressistas que apoiavam Feijó. As duas facções dariam origem, mais tarde, aos dois partidos do segundo reinado: Conservador ou Saquarema e o Liberal ou Luzia. (Wernet, 1984: 67).

89 Como traço peculiar, a revolta dos Cabanos no Pará representou o momento em que a classe trabalhadora daquela região coloca-se frontalmente em oposição a estrutura oligárquica. Segundo Renato Guimarães: "Nos compêndios oficiais de história, a Cabanagem via de regra define-se por uma insurreição popular que eclodiu em Belém a 7 de janeiro de 1835 , tomou conta de praticamente toda a
} 
Maranhão e Piauí, ambas alistando as camadas "mais miseráveis do povo" (Rodrigues, 1986: 54). Por isso mesmo foram chefiadas por liberais e "rigorosamente exterminadas a ferro e fogo e punidos sem contemplação os seus cabeças.” (Rodrigues, 1986: 54).

$\mathrm{O}$ rigor que encharcou de sangue o solo brasileiro não pertenceu ao Partido liberal ou conservador, mas ao Poder das oligarquias, especialmente latifundiárias e mais ainda ao divórcio entre o Poder e a Sociedade, que sempre existiu e ainda existe, porque é um fenômeno da estrutura sócio-econômica brasileira. Com ou sem partido conservador, a reação conservadora se inicia logo em 1831, embora só venha ao Poder em 1836, pois o Poder pertencia aos latifundiários, para os quais o político liberal moderado ou conservador monarquista pouco importava; o que importava era a conservação da ordem e a destruição dos exaltados. Não temos sido um povo de latifundiários. Os interesses vitais do país estavam na agricultura e esta era dominada pela grande propriedade territorial, que pedia vassalos obedientes. (...) O Poder e o Partido Conservador abafaram as revoluções com sangue, muito sangue, especialmente aquelas que pelo seu conteúdo social representavam maior perigo para as instituições mantenedoras de seus privilégios. (Rodrigues, 1966: 48).

A história cruenta do período regencial sistematiza a condição desumana das lideranças liberais no Brasil. Assim, em nenhum momento, dos anos que representam esse tumultuado movimento, tivemos uma liderança que se interessasse em conciliar-se com o povo e, dessa forma, realizar efetivamente reformas sociais de porte. Por mais que ganhe a feição de um governo republicano, na prática, os Regentes nunca se propuseram a uma conciliação nacional e popular. À estabilidade granítica das instituições corresponde uma mera instabilidade governamental, logo, as alternâncias constantes nos nove anos da Regência foram determinantes para um período extremamente cruento. A história cruenta mostra os limites de um liberalismo que não funcionou na vacância do imperador, haja vista que desde a abdicação, os embates políticos visavam estancar reivindicações maiores e amplas. Para tanto, a solução

província do Pará - que na época também compreendia o território do atual Estado do Amazonas - e empolgou o governo provincial até 13 de maio do ano seguinte, quando o exército rebelde foi forçado a abandonar Belém às forças que o governo imperial mandara a combatê-lo. (...) Numa percepção mais abrangente, porém, a Cabanagem deve ser entendida como um momento particular, culminante, do processo de luta pela independência brasileira na região amazônica. Essa luta assumiu feição violenta desde o limiar da década de 1820, absorveu uma participação sempre mais maciça e mais ativa de caboclos, índios, negros e outros elementos da população trabalhadora, aos quais a historiografia oficial batizou genericamente pelo nome das choças e casebres - cabanas - em que habitavam, e só terminou no final da década seguinte, com a rendição dos últimos contingentes organizados de "cabanos" e a consolidação do mando imperial na província." (Guimarães, 1978: 100). 
"legal" da regência serviu para a manutenção do mesmo estamento no poder, quando da eclosão das revoltas, e alguma possibilidade de esfacelamento político, de modo que os responsáveis pela política apelaram à instalação de formas autoritárias de poder ${ }^{90}$.

Um intelectual do porte de Caio Prado Junior também avalia de forma crítica o movimento regencial, tendo uma aproximação com José Honório Rodrigues, principalmente ao tratar as revoltas como um "massacre ao povo". Um exemplo disso seria sua análise a respeito da Balaiada, apontando nesse movimento uma revolta que contava com uma "enorme massa sertaneja que representa o mais saliente papel na revolta dos balaios." (Prado Jr, 1994: 79).

Não se apresenta a Balaiada como um único movimento mas, pelo contrário, caracteriza-se por sucessivos e ininterruptos levantes. Deu-se o primeiro na Vila da Manga, pequena povoação da margem do rio Iguará, repercutindo logo em outros pontos, e rapidamente se estendendo desde o litoral, defronte a ilha em que se ergue a capital de São Luís, até Passos Bons, na margem do Parnaíba, e pelo sertão do Piauí a dentro. (...) Na origem desse levante, vamos encontrar as mesmas causas que indicamos para as demais insurreições da época: a luta das classes médias. Especialmente urbana, contra a política aristocrática e oligárquica das classes abastadas, grandes proprietários rurais, senhores de engenho e fazendeiros, que se implantara no país. Este elemento democrático radical era no Maranhão conhecido pelo nome de Bem-te-vi - do jornal O Bemte-vi -, sustentava suas ideias na capital da província. Mas, dada a palavra de ordem da insurreição por este partido, a revolta toma uma feição própria, independente do partido que a provocara, e degenerando num levante de massas sertanejas, por cerca de três anos domina todo o interior da província. Os mesmos bem-te-vis, procurando embora tirar do movimento vantagens políticas em proveito próprio, dele se afastam logo que toma vulto, passando-se para a reação. (Prado Jr, 1994: 79).

\footnotetext{
${ }^{90}$ Com a abdicação pouco haviam melhorado as relações entre a Câmara e o Executivo, Bernardo, ministro em 1831, ensaia o parlamentarismo, com a ficção da unidade do governo e a responsabilidade coletiva. Era, unicamente, um precedente, que não lograva fixar-se. A hostilidade entre os dois poderes culminou, com a renúncia de Feijó, que não sofria o papel de rei constitucional, vedando-lhe a lei dissolver a Câmara (lei de 7 de junho de 1831). Seu substituto, Araújo Lima, perfeito rei constitucional, aceitou o parlamentarismo, que nascia dos costumes e não da Carta outorgada, para prolongar-se até a queda do Império. O novo regime consolida-se como se nota pelos acontecimentos, não pela reação contra o despotismo, mas como meio termo entre o liberalismo e a autoridade, porfiando em fortalecer a última. Prestigia-se na obra de fortalecimento do poder, com as medidas posteriores de centralização e de limitação às forças liberais, centrífugas, da nação. É o primeiro passo da reconstituição do estamento burocrático, que iria fazer o Segundo Reinado. Essa característica extrema-o, na natureza, do parlamentarismo inglês, com o qual se assemelha na superfície. Nasce e se forma no espírito do Brasil tutelado, orientado e controlado por uma categoria social estável, permanente, que se estratificou fora da Câmara Temporária. (Faoro, 1958: 166).
} 
Não podemos, dado os exemplos contundentes elencados, continuar com a afirmação de que durante a regência tivemos uma mera, passagem a maioridade, como salientava Oliveira Lima. Mas sim, tratou-se de um momento que exasperou as condições de uma História Cruenta, isso porque não houve mudanças e formas de rompimento com a estrutura do Estado patrimonial até então reinante, como diagnosticado por Raymundo Faoro ${ }^{91}$. Além disso, apesar da concentração reacionária de 1836 - movimento conhecido como "Regresso Conservador" - e sua vitória com a renúncia de Feijó no ano seguinte, a intranquilidade do Império não terminara, ainda que em franco declínio. "Já não se nota esta agitação persistente em todo o país, esta repetição contínua, por toda parte, de movimentos revolucionários que amainavam aqui apenas para recrudescer e mantinham o Império "num estado de perene tranquilidade" (Prado Jr, 1994: 87). Porém, com a eclosão de revoltas que deixavam em evidência as precárias condições que o Estado brasileiro moldava-se e, mais, sem que houvesse qualquer tipo de proposta que visasse a instituição de reformas que atendesse as reivindicações da população, "abalaram a plena confiança na regência” (Prado Jr, 1994), mostrando seus limites, mesmo com a árdua tentativa de se manter minimante organizada $^{92}$. Dessa forma, perdendo cada vez mais a credibilidade, sem criar mecanismos para equacionar as lutas sangrentas entre as classes sociais que compunham a mal acabada ordem social de um país escravocrata, José Honório Rodrigues esclarece que o cenário para a conciliação estava armado e esta seria selada com a Maioridade ${ }^{93}$.

\footnotetext{
${ }^{91}$ Com relação à manutenção da estrutura patrimonial do Estado, Faoro tece os seguintes comentários: "A base de domínio provincial era o emprego público, vinha da autoridade que governava o Estado, base que era também do local. Descentralização municipal ou provincial e centralização significam, no fundo, o controle do cargo, sem o qual os potentados nada valiam ou eram postos fora da lei. A reconstituição do estamento burocrático, ensejado pela reação de 1836, faz-se com uma manobra singela e primária: a interferência do centro na nomeação de funcionários." (Faoro, 1958: 161).

${ }_{92}$ Segundo o destacado político Bernardo Pereira de Vasconcellos: "Quem nos deve governar é o país, o governo de si mesmo é o único governo que convêm aos homens civilizados: e o que desejo eu? É que quando se apresente algum boato arreado com o nome de opinião pública, que procuremos examiná-lo, consultemos todos os sentimentos, todas as opiniões, todos os interesses, e depois de termos procurado chegar ao verdadeiro conhecimento dos verdadeiros interesses do país, tanto pela discussão espontânea, como pela discussão oficial, conheçamos então a opinião pública, então obedeçamos a seus decretos. Não me parece, pois, fundada a acusação que se me tem feito, de que eu não desejo o Ato Adicional, muito mais quando aparece todo o interesse da minha parte para que ele floresça, e não descubro benefício algum na sua anulação. (...) Mas eu torno a pedir que se apontem os fatos que demonstram que a administração atual atenta contra as instituições do país." (Vasconcellos, 1999: 253).

${ }^{93}$ Parece-nos ser pertinente pensarmos numa aproximação entre Caio Prado Jr e José Honório Rodrigues, no que diz respeito ao desfecho da regência. Assim, para o intelectual paulista a crise política do final dos anos de 1830, com a intensa disputa entre as facções que compunham nosso cenário político leva a formulação da ideia da Maioridade, como forma de equacionar as disputas políticas que se
} 


\section{6 - Movimento abolicionista - Outro exemplo de História Cruenta}

As condições em que o escravo foi inserido na sociedade brasileira têm uma particularidade inconteste, ele não "veio" ao Brasil e sim foi "trazido", como ressalta José Honório ao traçar um longo painel da chegada do africano a este país. A distinção se faz necessária para que tenhamos a verdadeira dimensão das condições subumanas às quais estavam os escravos submetidos.

O trabalho escravo, como parte necessária aos interesses de grandes proprietários de terra, era identificado como forma possível de superar a ausência de força de trabalho em proporções que atendessem aos interesses da grande lavoura. Se esta obra fosse uma mercadoria em cima das quais os comerciantes pudessem ganhar, comprando barato e vendendo caro, melhor ainda. $\mathrm{O}$ africano foi, portanto, trazido para exercer o papel de força de trabalho compulsório numa sociedade que estava se organizando em função da grande lavoura.

No Brasil não havia o interesse em promover o sustento dos produtores, mas em produzir para o mercado consumidor em quantias que o ganho do setor proprietário fosse o mais expressivo possível. Considerava-se a agricultura de subsistência um desperdício de investimento e mão-de-obra que deveriam ser dirigidos à grande lavoura. Dessa forma, a racionalidade e a eficiência da grande lavoura só poderiam ser avaliadas na medida em que atingissem esses objetivos para os quais a mão-de-obra escrava era fundamental. (Costa, 1998: 493).

O funcionamento do sistema de escravidão era destrutivo e opressor, não permitindo a organização por parte dos cativos. No entanto, a alta lucratividade dos proprietários permitiu que a complexidade de sua organização a identificasse com a rotina de uma empresa. Os comerciantes e proprietários de escravos trabalhavam com a submissão daqueles com demonstrações constantes de crueldade. A pressão da competição comercial ajudou a difundir novas técnicas e a disciplinar o escravo rebelde ou preguiçoso.

intensificavam. “A redução do prazo legal em que ela se tinha de naturalmente operar impõe-se pela ânsia de sair deste período de transição, de consolidar as instituições com o desaparecimento dessa forma, passageira por natureza, qual a Regência; pela esperança, enfim, de encontrar na ascensão do menino imperador ao trono, a tranquilidade ao país.” (Prado Jr, 1994: 87). 
Embora a maioria dos empregados livres concordasse implicitamente com a degradação do povo negro, eles não precisavam ser motivados pela hostilidade racial. Não foram raros os episódios de violência gratuita por causa da vulnerabilidade dos escravos, mas os sistemas escravistas bem sucedidos combinaram de forma sistemática coerção com produção e manutenção da ordem. Os manuais de administração de plantations costumavam enfatizar que as punições deviam ser aplicadas de forma metódica e previsível. A superpopulação dos navios negreiros que cruzavam o Atlântico e as provisões insuficientes de alimento e água para os cativos causaram taxas de mortalidade muito mais altas do que entre os migrantes livres. Mais esses métodos eram mais lucrativos, porque um grande número de escravos podia ser transportado em cada viagem. $\mathrm{O}$ funcionamento comum dos sistemas escravistas apresentava um pouco da impessoalidade e da lógica funcional da organização empresarial moderna. Mesmo assim, as próprias fazendas escravistas baseavam-se na relação pessoal característica entre superintendente, feitor e trabalhadores escravos. (Blackburn, 2003: 31).

Nas condições descritas, a "rebeldia negra" foi uma manifestação da problemática instituída com a escravidão, representou um sacrifício imenso, violento e processo histórico que originou todo um debate historiográfico. Como reação ao sistema escravista, a rebeldia negra foi um "processo contínuo, permanente e não esporádico, como fez ver a historiografia oficial." (Rodrigues, 1970: 56).

Neste subitem, nosso intuito é apontar como fora a discussão realizada a respeito do abolicionismo e consequentemente, acerca do fim da escravidão em território nacional. Cabe ressaltar que trata-se de tema de grande controvérsia, pois foi objeto de análises em que se procurava destacar o processo como resultado incruento, em que a "via institucional", ou seja, através de acordos e conluios políticos (Rodrigues, 1970), fora a forma escolhida para a mudança da ordem escravocrata, abortando qualquer inserção e participação do próprio escravo nesse debate.

$\mathrm{Na}$ contenda, o aspecto limitador da ação dos escravos está, mais uma vez, plasmado pelo tradicionalismo imperante entre nós. A história deixa de ser cruenta quando não há acordos entre os setores que compõem a elite dirigente do país e os setores subalternos. A conciliação entre os grupos rivais, porém não antagônicos, é elemento determinante para a caracterização do momento político social em cruento ou incruento. Um bom exemplo disso foi o processo que levou ao fim da escravidão, isto é, 
quando conservadores e liberais não mais comungaram, segundo seus interesses, com tal manutenção, surgindo, assim, uma fratura em relação ao pensamento que esses grupos tinham acerca da escravidão. Logo, seu fim, em 1888, é consequência desse racha. Esse cenário em que a disputa político levou-os a uma indisposição entrelaça-se à deterioração do sistema escravista, pois segundo Marco Aurélio Nogueira:

Aos problemas inerentes a um sistema fechado e autocrático como era o monárquico, veio se somar um movimento mais fundo: o do desenvolvimento econômico posto em marcha a partir dos anos 40, cuja objetivação trouxe consigo uma nova dinâmica social. O regime mesmo, ao impulsionar a expansão da economia (particularmente comércio e agricultura de exportação), criava sem o saber condições que acabariam por inviabilizá-lo; até certo ponto, não seria capaz de acompanhar as mudanças que se sucederiam, bem como de responder às suas exigências. Foi ultrapassado pelos fatos da vida econômica. (Nogueira, 1984: 69).

O contexto que ganhava novos ares e criava elementos para uma mudança circunstancial com a abolição, "a escravidão tornara-se uma instituição desmoralizada" (Costa, 1999) corresponde a própria condição de sistema "fechado e autocrático" que era a monarquia, um sistema que não criava mecanismos para acompanhar o próprio ritmo de suas mudanças. A questão que envolve o conjunto de leis abolicionistas que surgiram ao longo da segunda metade do século XIX, em grande medida, segue essa premissa. Segundo Emília Viotti da Costa:

Por volta da década de 1880 , era óbvio que a abolição estava iminente. O Parlamento, reagindo do abolicionismo de dentro e de fora do país, vinha aprovando uma legislação gradualista. As crianças nascidas de mães escravas foram declaradas livres em 1871, e em 1885 a liberdade foi garantida para os escravos com idade superior a 65 anos. o movimento abolicionista tornou-se irresistível nas áreas cafeeiras, onde quase dois terços da população escrava estava concentrada. Com uma nova consciência de si mesmos e encontrando apoio em segmentos da população que simpatizavam com a causa abolicionista, grandes números de escravos fugiam das fazendas. A escravidão tornou-se uma instituição desmoralizada. Quase ninguém opunha-se à ideia de abolição, embora alguns reivindicassem que os fazendeiros deviam ser indenizados pela perda de seus escravos. O único grupo que, no Parlamento, resistiu até o último minuto foi o dos representantes dos fazendeiros das antigas áreas cafeeiras, para quem os escravos representavam um terço do valor de suas hipotecas. Em maio 
de 1888 eles votaram contra a lei que aboliu a escravidão no Brasil. (Costa, 1999: 362).

Com o intuito de procurar a explicação desse contexto, surge uma forma, do ponto de vista teórico, de apequenar a ação do negro frente a violência em que sua condição de escravo o jogava, desse modo, houve por parte de muitos intelectuais, a conivência com a afirmação de que o sistema escravista não conseguiu articular levantes, e estes, quando ocorreram, foram meras revoltas esparsas e esporádicas. $\mathrm{O}$ debate suscitado resultou na interpretação oficial do sistema escravocrata, apresentado como aquele que se baseou na legitimidade da propriedade e não no preconceito racial.

A versão de um quadro paternal e doce, no qual a confraternização predominou sobre a animosidade, especialmente nas relações domésticas, falsamente generalizadas, subverteu a verdadeira inteligência do processo. (...) Não é exato que o preconceito não tivesse aqui. Como por toda parte, infectado as relações raciais de senhores e escravos. No Brasil, a vitória lenta sobre o preconceito, ainda não de todo conquistada, representa um dos aspectos mais positivos do nosso processo histórico humanista, progressista e civilizatório. Sofremos todos os preconceitos, fomos contra os índios, negros e judeus, e aprendemos a tolerância na educação da vida, na obra popular da miscigenação, que abrandou e pacificou relações raciais e sociais. Suportamos todas as lutas, especialmente as da gente mais humilde, e a confraternização conviveu com o combate. (Rodrigues, 1970: 68).

Como nas palavras de José Honório Rodrigues, "um quadro paternal e doce", assim era pintado o contexto escravocrata. Despido da violência e dos preconceitos e das lutas, aparecido mais recentemente para engrandecer o projeto de controle do Estado e a forma cruenta de suas lideranças. No entanto, essa condição ganha maiores contornos com as discussões que foram feitas para chegarmos ao momento de fim da escravidão. "Diz que entre nós a escravidão é suave, e os senhores bons, porém, é que toda a escravidão é a mesma, e quanto à bondade dos senhores esta não passa de resignação dos escravos." (Nabuco, 1999: 119). A violência com que o escravo era tratado foi apequenada por parte daqueles intelectuais que tratavam das condições do escravo e de todas as instituições que envolviam a escravidão, todavia essa não representava um "sistema fechado" (Rodrigues, 1970: 69), não existia um critério 
restritivo entre o escravo e as porções livres da sociedade, dando margem a múltiplos contatos entre libertos e escravos, gerando, como consequência a essa peculiaridade, a mestiçagem.

Foi sempre característica dos pensadores brasileiros, desde o século XIX, pautar-se no referencial teórico elaborado pelos cientistas ocidentais, ou seja, o pensamento ocidental - tanto americano, como europeu. Segundo Kabenguele Munanga:

A discussão travada por alguns iluministas a respeito do caráter ambivalente da mestiçagem seja para explicar e confirmar a unidade da espécie humana (Buffon, Diderot), seja para negá-la (Voltaire); e ideia da mestiçagem tida ora como um meio para estragar e degradar a boa raça, ora como um meio para reconduzir a espécie a seus traços originais; as ideias sobre a degenerescência da mestiçagem etc., todo o arcabouço pseudocientífico engendrado pela especulação cerebral ocidental repercute com todas as suas contradições no pensamento racial da elite intelectual brasileira. (...) Como aconteceu na maioria dos países colonizados, a elite brasileira do fim do século XIX e início do século XX foi buscar seus quadros no pensamento na ciência européia ocidental, tida como desenvolvida, para poder não apenas teorizar e explicar a situação racial do seu País, mas também, e, sobretudo, propor caminhos para a construção de sua nacionalidade, tida como problemática por causa da diversidade racial. (Munanga, 2006: 53).

Entretanto, no desdobramento das discussões a respeito do ideário da mestiçagem no Brasil, os intelectuais do país, em sua grande maioria, apesar de terem sido "alimentados pela ciência ocidental" (Munanga, 2006), elaboraram propostas originais, diferentes das disseminadas em outros locais das Américas. Isso porque contávamos com uma diversidade de intelectuais que, a reboque das condições locais, expressavam, em sua produção, certa particularidade. Esta, de um modo geral, passa a ser modificada a partir da segunda metade do século XIX com a por meio da alteração do eixo econômico do país. ${ }^{94}$

\footnotetext{
${ }^{94}$ Segundo Lilia Schwarcz: "A partir da década de 50 do século XIX, ocorre uma paralela diversificação entre as instituições científicas, ou seja, os estabelecimentos situados nas cercanias dos novos centros econômicos do país foram progressivamente mais bem aquinhoados do que os demais. (...) Outro aspecto de destaque é a tendência à conformação de campos acadêmicos distintos o que implicou uma diversificação nas áreas de atuação das elites intelectuais nacionais. Assim, se a maior parte da "classe ilustrada brasileira" tinha em comum a formação em Coimbra (ou mais raramente em outra universidade européia) e uma carreira burocrática, a partir de então começam a delinear-se especializações
} 
Para caracterizar esse pensamento brasileiro a respeito da mestiçagem, é necessário identificar aqueles que produziram uma interpretação pejorativa, destacando seus efeitos e suas consequências no processo de formação da identidade nacional. Nesse sentido, acreditamos que o caso mais específico seja o de Oliveira Vianna, pois o autor de Evolução do povo brasileiro foi duramente criticado por José Honório Rodrigues como expressão de um pensamento ultra-reacionário. Além disso, o intelectual fluminense apoiava-se na defesa da necessidade de um branqueamento na sociedade brasileira. ${ }^{95}$

Oliveira Viana tenta explicar a formação do país a partir do contexto típico do final dos anos 20 e começo dos 30, momento em que se consolidava no território nacional um movimento de centralização do poder e superação da ordem republicana anterior. ${ }^{96}$ Crítico ao governo republicano, responsabiliza-o pela ruptura do comando e da unidade havida no Império, consideradas fundamentais na estruturação política do país. Acredita que a precariedade da constituição política do povo brasileiro tornava-o avesso à democracia, principalmente por que essa requer o fim do personalismo, das relações pessoais de privilégios e de respeito à autoridade legal e à hierarquia. $^{97}$

A constituição de uma sociedade mestiça seria um dos fatores que impossibilitaria um governo nos moldes das democracias liberais modernas. A maior frequência de traços das raças inferiores seria uma das razões para o atraso brasileiro, que poderia ser superado com o "branqueamento" e educação de sua população. Segundo Oliveira Vianna, tanto o negro como o índio teriam grandes dificuldades de integrar-se e de tornarem-se civilizados.

profissionais diretamente associadas às diversas instituições e suas condições típicas no Brasil." (Schwarcz, 1993: 25).

${ }^{95}$ Iremos utilizar principalmente Evolução do povo brasileiro, pois acreditamos que nessa obra fica mais explícita a ideia de mestiçagem de Oliveira Viana, além de já termos tratado do jurista fluminense no capítulo referente ao pensamento social brasileiro.

${ }^{96}$ Boris Fausto tece os seguintes comentários a respeito: "Ao se fazer a análise das concepções que colocam as classes médias no centro da revolução de 1930, é preciso considerar que, se não se pode falar de uma burguesia industrial favorável à Revolução é incontestável a presença de setores pequenoburgueses, na campanha eleitoral e após o episódio revolucionário, não podem ser reduzidas apenas a um apoio da categoria social, seriam impossíveis sem a sua larga adesão, tendo-se em vista o caráter muito limitado da intervenção do proletariado". (Fausto, 1970: 82).

${ }^{97}$ Para Oliveira Vianna, não existiria no Brasil condições do povo ter autonomia nas suas decisões devido à origem colonial das instituições no país, segundo o autor: "Os povos de origem colonial como o nosso possuem duas constituições políticas: uma escrita que não se pratica que está em nossas leis e códigos políticos; outra não escrita, porém viva que é a que o povo pratica, adaptada a seu espírito, à sua mentalidade e estrutura." (Vianna: 1952: 422). 
Os negros, quando sujeitos à disciplina das senzalas, mantém-se dentro de certos costumes de moralidade e sociabilidade, imposta pelos senhores, que os assimilam, tanto quanto possível, à raça superior. Abolida a escravidão, são entregues, em massa, à sua própria direção, decaem e chegam progressivamente a situação abastardada, em que vemos hoje. (...) Já o índio, há no seu temperamento ou na sua estrutura mental, como que uma certa dureza ou imaleabilidade, absolutamente invencível à ação educadora dos agentes civilizadores: ele é incivilizável por excesso de personalidade, por carência de ductilidade mental, que permita afeiçoar-se segundo as nossas ideias e os nossos sentimentos. (Vianna, 1956: 158/9).

Outro fator que afasta o índio da civilização seria seu desprendimento, seu nomadismo e sua falta de ambição, tornando-o incompatível com a existência metódica, ordenada e medida do homem civilizado. Vianna sustenta suas argumentações tendo como base as teorias raciais, creditando ao "ariano" o papel civilizador, "entre a mentalidade do homem branco e a do homem africano puro há uma diferença substancial e irredutível que nenhuma pressão social ou cultural, por mais prolongada que seja, será capaz de vencer e eliminar." (Vianna, 1956: 160).

Acredita ainda que as dificuldades encontradas por índios e negros para uma "possível" ascensão social ocorrem devido à indiferença e desconfiança frente aos valores e objetivos arianos. Desse modo, caberia à "raça branca" organizar e legislar, impondo ordem às camadas inferiores, compostas pelos inúmeros efeitos da mestiçagem que se operou entre nós.

Os mestiços podem ter valor quando herdam os genes do grupo superior (raça branca) - mestiços superiores - mas, de um modo geral, prevalecem os mestiços inferiores, devido à própria capacidade eugênica de suas raças de origem, tendendo a empurrá-lo para o grupo inferior, destruídos pela ação regressiva de atavismos bárbaros. (...) O negro, o índio, os mestiços de um e de outro, são na sua generalidade - a exceção dos mestiços superiores - destituídos de vontade, da capacidade de querer, de senso de continuidade, características das naturezas inteiriças, monolíticas, são por isso, ao mesmo tempo, apáticos e impulsivos. Na composição de nosso caráter coletivo entram, mas apenas uma força revulsiva e perturbadora. Nunca, porém, como força aplicada a uma função superior: como elemento de síntese, coordenação e direção. (Vianna, 1956: 162). 
Para Vianna, tanto os negros como os índios só se fazem agentes de civilização quando caldeiam-se com o branco, ou seja, quando perdem sua pureza racial, sendo que o "mestiço superior" (Vianna, 1956), capaz de civilizar-se, só o faz quando deixa de ser mestiço para tornar-se branco. O grande impeditivo nesse sentido é que mantém uma "mentalidade mestiça". “(..) Ao invés de se manterem, quando ascendem, dentro das características híbridas do seu tipo, ao contrário, só ascendem quando se transformam e perdem essas características, quando deixam de ser psicologicamente mestiços, porque se arianizam." (Vianna, 1956: 178).

Representando uma versão radical do ideal do branqueamento, articula, em sua análise, a necessidade de uma evolução simultânea da raça, da sociedade e das instituições políticas. É aí que reside uma das contradições que cercam o pensamento do autor no que concerne às teorias raciais. Pois, apesar de sua admiração pelos teóricos das raças (Ratzel, Gobineau, Lapouge etc), e sua insistência nos conceitos de raças superiores e inferiores; raça ariana e raças primitivas, ele não via tais diferenças como absolutas. Amparando-se nesses pressupostos, chegou a uma interpretação incompatível com as premissas do racismo científico: que o Brasil se tornaria branco por obra de sucessivas miscigenações: “... o coeficiente da raça branca eleva-se cada vez mais em nossa população (...) neste trabalho de arianização de nosso povo, há outros colaboradores mais enérgicos do que a imigração das raças brancas da Europa" (Vianna, 1956). Segundo o autor fluminense a existência de fatores de maior relevância acaba criando uma naturalização dessa superioridade, elevando assim, a construção de uma nação homogênea no futuro. “(...) Há as seleções naturais e sociais, que aceleram extraordinariamente entre nós a rapidez do processo redutor dos elementos bárbaros." (Vianna, 1956: 178).

Fica evidente que a maneira pejorativa com que Oliveira Vianna traça a mestiçagem na sociedade brasileira, opõe, daqueles que a identificaram como traço marcante na formação da sociedade brasileira. Entre esses autores destaca-se a figura de Gilberto Freyre.

Não iremos nos deter na análise que o intelectual de Apipucos faz da mestiçagem, porém cabe ressaltar que nesse sentido, as assertivas são de grande valia para apontar com sua obra, mesmo representando uma análise liberal do país ${ }^{98}$, a mestiçagem entre o africano e o português criou uma "miscibilidade" inovadora e sem

\footnotetext{
${ }^{98}$ Ver nesse sentido o já citado prefácio de Antonio Candido (1996) para o livro "Raízes do Brasil" (Hollanda, 1996).
} 
igual na história da humanidade, sendo elemento decisivo para que na região da América portuguesa fosse instituída uma "nova civilização" plasmada a partir dessa integração racial inovadora ${ }^{99}$.

Em sentido diferente de Vianna e Freyre, ambos discutindo basicamente a atuação do "homem novo", ou seja, aquele que surge do processo colonizador, José Honório Rodrigues centra sua preocupação no trato violento que fora dispensado ao negro e índio na composição da sociedade mestiça. Além disso, avalia que a mestiçagem fora um grande empecilho para que houvesse uma mobilização social digna de romper com a forma violenta e desumana a que foram tratados os cativos na colonização da sociedade brasileira. O caráter cruento omitido pelos intelectuais Vianna e Freyre, remonta em apequenar, com relação à teorização do fato, a resistência dos cativos e mais, em não levar em consideração que a mestiçagem, para além das peculiaridades que suas tematizações resgatadas, foram um obstáculo na "rebeldia negra".

A mestiçagem abatia as resistências, facilitava a confraternização, acomodava, enfim, as grandes massas negras. A confraternização, especialmente dos escravos domésticos - casos isolados de maior acomodação - foi um dos elementos que diminuíram o vigor da luta revolucionária e fortaleceram a solução pacífica gradual. (...) a via crucis para os escravos, das reformas lentas e pausadas, abria uma fronteira macia de contemporização, que exigia a

\footnotetext{
${ }^{99}$ A respeito do assunto, Gilberto Freyre tece os seguintes comentários: "A mobilidade foi um dos segredos da vitória portuguesa; sem ela não se explicaria ter um Portugal quase sem gente, um pessoalzinho ralo, insignificante em número conseguido salpicar virilmente do seu resto de sangue e de cultura populações tão diversas e a tão grandes distâncias uma das outras: na Ásia, na África, na América, em numerosas ilhas e arquipélagos. A escassez de capital homem, supriram-na os portugueses com extremos de mobilidade e miscibilidade: dominando espaços enormes e onde quer que pousassem, na África ou na América, emprenhando mulheres e fazendo filhos, em uma atividade genésica que tanto tinha de violentamente instintiva da parte do indivíduo quanto de política, de calculada, de estimulada por evidentes razões econômicas e políticas da parte do Estado. (...) Os indivíduos de valor, guerreiros, administradores, técnicos, eram por sua vez deslocados pela política colonial de Lisboa como peças de um tabuleiro de gamão: da Ásia para a América ou daí para a África, conforme conveniências de momento ou da região. (...) Transportam-se da África para o trabalho agrícola no Brasil nações quase inteiras de negros. Uma mobilidade espantosa. O domínio imperial realizado por um número quase ridículo de europeus correndo de uma para outra das quatro partes do mundo então conhecido. (...) Quanto a miscibilidade, nenhum povo colonizador, dos modernos, excedeu ou sequer igualou nesse ponto os portugueses. Foi misturando-se gostosamente com mulheres de cor logo ao primeiro contato e multiplicando-se em filhos mestiços que uns milhares apenas de machos atrevidos conseguiram firma-se na posse de terras vastíssimas e competir com povos grandes e numerosos na extensão de domínio colonial e na eficácia de ação colonizadora. A miscibilidade, mais do que a mobilidade, foi o processo pelo qual os portugueses compensaram-se da deficiência em massa ou volume humano para a colonização em larga escala e sobre áreas extensíssimas. Para tal processo prepara-os a íntima convivência, o intercurso social e sexual com raças, cor, invasoras ou vizinhas Penínsulas, uma delas, a de fé maometana, em condições superiores, técnicas e de cultura intelectual e artística, a dos cristãos louros." (Freyre, 2005: 71).
} 
manutenção das condições degradantes da escravidão, mas não impunha a abnegação total ou o sacrifício da vida. Temos, assim, outra tese, ao lado da insurreição racial permanente, a da coexistência desta com a acomodação, juntamente com os instrumentos legais que vão sendo criados pela liderança das classes dominantes. (Rodrigues, 1970: 78).

A acomodação, dessa forma, é entendida como fruto da personalidade gestada pela miscigenação. Perde-se o elemento de identidade que poderia criar uma forma de repulsa ao conformismo, porém, avaliá-se que a miscigenação criou uma "temperança" ${ }^{100}$, aspecto fundamental da constituição do povo brasileiro. Todavia, para José Honório Rodrigues, a eliminação dos conflitos que se originaram na questão escravista teve forte ligação com o conformismo impetrado pelas "lideranças arcaicas" e pela dissimulação que a miscigenação plasmou no Brasil. Essa tradição arcaica, que acredita na história unicamente incruenta, teme as reformas, teme perder a situação satisfatória e confortável em que vive e procura, para perpetuar essa condição, não dar margens a mudanças que fossem legítimas para o povo brasileiro.

A identificação da miscigenação como algo que desmobiliza as relações de enfrentamento por parte dos escravos é um dos aspectos que José Honório Rodrigues aponta para a formação de uma sociedade que procura mobilizar os seus valores e sua real força de participação. Outra questão para qual o historiador carioca chama atenção é a limitação dos anseios liberais que imperavam no Brasil, porém, devido à escravidão, do liberalismo no país, tornara-se uma quimera, algo desconexo da estrutura do capital e, portanto, da lógica societária do Brasil no século XIX. Para embasar seu argumento, procura demonstrar como o processo de adoção de novas leis foi permitindo que o escravo pudesse resgatar-se por si próprio da escravidão, através do seu trabalho, isto é por meio do seu pecúlio. Depois, permitindo a elegibilidade dos libertos, determinando

\footnotetext{
${ }^{100} \mathrm{~A}$ assunção de sua própria identidade pelos brasileiros, como de resto por qualquer outro povo, é um processo diversificado, longo e dramático. Nenhum índio criado na aldeia, creio eu, jamais virou um brasileiro, tão irredutível é a identificação étnica. Já o filho da índia, gerado por um estranho, branco ou preto, se perguntaria quem era, se já não era índio, nem tampouco branco ou preto. (...) Buscando uma identidade grupal reconhecível para deixar de ser ninguém, ele se viu forçado a gerar sua própria identificação. (...) O negro escravo, enculturado numa comunidade africana, permanece, ele mesmo, na sua identidade original até a morte. Posto no Brasil, esteve sempre em busca de algum irmão da comunidade longínqua com quem confraternizar. Não um companheiro, escravo ou escrava, como ele próprio, mas alguém vindo de sua gente africana, diferente do todos os que viam aqui, ainda que eles fossem negros escravos. (...) O brasilindio como o afro-brasileiro existiram numa terra de ninguém, etnicamente falando, e é a partir dessa carência essencial, para livrar-se da ninguendade de não-índios, não-europeus e não-negros, que eles se vêem forçados a criar a sua própria identidade étnica: a brasileira. (Ribeiro, 1997: 131).
} 
um prazo de duração da escravidão, a partir da lei de 28 de setembro de 1885, ou de seu regulamento, de 12 de junho de 1886, em treze ou catorze anos e meio. "Tudo isso modifica a condição do escravo, e os legisladores começam a falar no escravo como gozando uma condição de statu liberi." (Rodrigues, 1970: 79).

A manutenção da escravidão e a discussão que ganha à proposta abolicionista na Câmara, no sentido constitucional levou parte da intelectualidade brasileira da segunda metade do século XIX a posicionar-se frente à temática da escravidão. ${ }^{101}$ José Honório Rodrigues, por sua vez, aponta como não foram plenamente discutidas as questões que estavam diretamente envolvidas com a escravidão, sendo as leis instituídas no Brasil desde a década de 30 do século XIX. Segundo o intelectual carioca:

Os momentos de retardamento impediram sempre os instantes de aceleração. A legislação é enorme e mais demora a marcha que anima. Domina sobretudo uma mentalidade gradualista que, beneficia os grande proprietários rurais, atrasa o país e impede o progresso do povo. Ela começa, em 7 de novembro de 1831, declarando livres os escravos vindos de fora do Império e impondo pena aos importadores; em 12 de abril de 1832 regulamenta-se esta lei; em 4 de junho de 1835, depois da Revolta dos Malés (janeiro de 1835), determinam-se as penas com que devem ser punidos os escravos que matem, firam e cometam ofensa contra seus senhores; em 4 de setembro de 1850, a lei da repressão do tráfico e os decretos de 14 de outubro e 14 de novembro deste ano, que regulamentam essa lei de 1831, representam o instante de aceleração. Ajuda-se, assim, a formar o capital nacional desviado para o tráfico, e agora voltado para os melhoramentos nacionais. (Rodrigues, 1965: 67).

A complexidade do caso escravismo-liberalismo entre, foi, no caso brasileiro pelo menos, apenas um paradoxo liberal. Segundo Alfredo Bosi:

O par, formalmente dissonante, escravismo-liberalismo, foi, no caso brasileiro pelo menos, apenas um paradoxo verbal. O seu consórcio só se poria como contradição real se atribuísse ao segundo termo, liberalismo, um conteúdo pleno e concreto, equivalente à ideologia burguesa do trabalho livre que se afirmou ao longo da revolução industrial européia. (...) Ora esse liberalismo ativo e desenvolvo simplesmente não existiu, enquanto ideologia dominante, no período que se segue à Independência e vai até os anos centrais do Segundo

\footnotetext{
${ }^{101}$ Para maiores detalhes da polêmica existente entre José de Alencar e Joaquim Nabuco ver: Nogueira
} (1984) e Schwarz (2001). 
Império. A antinomia tantas vezes acusada, e o travo de nonsense que dela poderia nascer (mas como é possível um liberalismo escravocrata?), merecem um tratamento rigoroso que os desfaça. (Bosi, 1999: 196).

Para exemplificar, seguindo os argumentos de José Honório Rodrigues, ficávamos longe de qualquer discussão a respeito da propriedade fundiária, ou mesmo do implemento de uma prática que valorize a força de trabalho livre. “(...) Não se toca na terra, nem se chega à libertação e muito menos aceita-se tranquilamente o fim da escravidão." (Rodrigues, 1965: 67). O pensamento cruento, que evita qualquer forma de integração a sociedade de classes afasta o ideal liberal de seu funcionamento no Brasil.

O país não tem mais paciência para ouvir falar em liberais que não são abolicionistas. Um Partido Liberal que não repudia a escravidão é um Partido de nome suposto", essas palavras de Joaquim Nabuco expressam o limite do liberalismo que os grupos políticos adotaram como linha mestra de suas ações. (...) Uniam-se todos, na manutenção do status quo, nas concessões graduais, atrasando o desenvolvimento do país, para benefício de uma classe, e não da nação. A conciliação, o compromisso político, que dominou o Estado Nacional, no Império e na República - divisões fictícias da realidade histórica - foi uma arte finória, desenvolvida e apurada pelas lideranças conservadoras fluminense, baiana e mineira, aquelas que tinham diante de si as grandes massas negras, as mais sofridas, as que tinham maiores reivindicações, as mais suscetíveis de aceitarem a palavra revolucionária. Conservadores do uti possidetis (o que possui) e liberais do status quo (no estado em que se encontra), não estavam realmente em oposição em qualquer coisa fundamental. Suas divergências são aparentes e suas lutas limitam-se à posse do poder. Ambos resumiam sua política ao progresso lento e refletido. (Rodrigues, 1970: 81).

A oposição a qualquer discussão que levasse adiante a possibilidade de efetivação da abolição foi responsável por um número expressivo de petições na Câmara. Os porta-vozes dos interesses escravistas exigiam medidas que pusessem fìm à agitação. Perseguiam os abolicionistas que ousavam pregar suas ideias nas cidades do interior, ameaçavam-nos de morte. Interrompiam de armas na mão, comícios abolicionistas. Seus capangas invadiam e quebravam as sedes dos jornais abolicionistas, expulsando-os das cidades. Usando de sua influência política, os fazendeiros tudo faziam para remover os juízes e outros funcionários públicos que davam apoio aos 
escravos ou mostravam simpatia pela Abolição. Diziam que o abolicionismo era um movimento artificial, promovido por desordeiros e irresponsáveis que ameaçavam o futuro das Nações. Pediam à Câmara que tomasse medidas para impedir a propaganda abolicionista. Citando uma dessas petições contrárias a abolição - que fora encaminhada a Câmara em 1884 -, Emilia Viotti da Costa explica que:

O movimento abolicionista que pretende acelerar a liberdade completa da escravidão no paiz não cogitando das terríveis consequências desse passo precipitado para a lavoura e o paiz em geral, obriga-nos a recorrer ao Parlamento Brasileiro, insistindo por adoção de medidas enérgicas e urgentes a fim de evitar que essa avalanche medonha em sua queda vertiginosa venha a arrazar completamente o futuro da lavoura, tão empenhada em nossos dias, não só pela carestia de braços, como pela falta de confiança e de capitais. Não há brasileiro que não sinta palpitar em seu peito o nobre e generoso sentimento de liberdade, não há lavrador que não aspire ver resolvido esse magno problema que agita o país, mas o momento não é chegado, essa solução não tem razão de ser com a marcha acelerada que fora da legalidade lhe querem dar os abolicionistas. Na ocasião oportuna, quando estiver a lavoura preparada para esse golpe decisivo, em nossos corações ecoará também esse grito simpático de liberdade. (Costa, 2001: 65).

A maneira de se encarar o problema expressa tipicamente o sentimento cruento e contrário às reformas por parte das elites. A concepção liberal, associada a maior dinâmica da sociedade encontrava-se entre os "dois liberalismos"102 e sua forma de ação era plasmar fatos que não permitissem que seus interesses pudessem ser afetados.

O liberalismo configura-se no Brasil por meio de possíveis caminhos instituídos pelos desdobramentos históricos de nossa emancipação política. Raymundo Faoro fala de "liberalismos", ambos acabam se formando como resultado das condições expressas na dissolução da Constituinte de 1823 e na Outorga de 1824, ou o outro, que

\footnotetext{
${ }^{102}$ A respeito do tema, as considerações de Roberto Schwarz são de grande importância para seu entendimento: "Impugnada a todo instante pela escravidão a ideologia liberal, que era a das jovens nações emancipadas da América, descarrilhava. Seria fácil deduzir o sistema de seus contra-sensos, todos verdadeiros, muitos dos quais agitaram a consciência teórica e moral de nosso século XIX. Já vimos uma coleção deles, No entanto, essas dificuldades permaneciam curiosamente inessenciais. (...) Por sua mera presença, a escravidão indicava a impropriedade das ideias liberais; o que, entretanto é menos que orientar-lhes o movimento. Sendo embora a relação produtiva fundamental, a escravidão não era nexo efetivo da vida ideológica, a chave desta era diversa e para descrevê-la é preciso retomar o país como um todo." (Schwarz, 2000:15).
} 
ficaria submerso e incompleto quando sua realização era a condição necessária para superar os entraves do passado. Para o primeiro o "elemento nacional", que compõe a corrente nacionalista, foi o ideário que fez eclodir as revoltas e manifestações de "caráter nativista" da "Inconfidência Mineira" (1789), até a Praieira (1848), esse liberalismo, ainda segundo Faoro, colidi com o Liberalismo de 1820 em Portugal, momento de sua reestruturação dinástica (Sérgio, 1992), dessa forma, ocorre, inevitavelmente, um conflito de interesses e o liberalismo português acabou ditando o perfil político de nossa Independência.

(...) O elemento nacional (grifo nosso) está no sentido certo: não se trata de um pensamento nacional, de um país como Nação, mas como núcleos não homogêneos, com um projeto - apenas como projeto - nacional. As circunstâncias - a dissolução do sistema colonial - teriam configurado as bases de uma consciência histórica, estamental e virtualmente de classe, sem que se possa configurar uma situação revolucionária, pelo menos no seu momento inicial pela ausência do projeto. Mas o quadro é um conjunto de possibilidades, em um processo difuso. Trate-se de uma consciência possível. A consciência possível não atinge a realização da consciência real. Explica-se, com isso, a filosofia política, livrescamente adotada, e a ideologia, perfilhada dogmaticamente, não se convertem na práxis, no efetivo fazer, realizar e transformar, mas em verbalismo desligado da realidade. (Faoro, 2008: 80).

A “consciência possível” desses quadros liberais acabou facilitando o caminho, aquela altura inevitável, de superação do regime monárquico, dos limites da própria escravidão e o implemento da República. O liberalismo brasileiro poderia ser consolidado como "fio condutor" do sistema político e da responsabilidade dos seus atores, porém, como José Honório Rodrigues já vaticinava, "no Brasil a estrutura é granítica, nada muda." (Rodrigues, 1965). Dessa forma, mesmo com o trânsito de regime político - a instalação da República - não foi possível a instalação do modelo democrático almejado pelo intelectual carioca. Mais uma vez, o nacionalismo liberal não fora a pedra de toque dos "homens de Estado." 


\section{III - José Honório Rodrigues e o contexto do golpe militar e a política externa independente: a práxis honoriana}

Neste capítulo, pretendemos discorrer a respeito da atuação de José Honório Rodrigues como crítico do golpe civil militar que assolou o Brasil em 1964, principalmente com relação à política externa adotada pelos militares.

A partir de 1964, o intelectual carioca adota uma postura de enfrentamento, deixa de ter participação constante nos seminários, como tinha até então, dentro da Escola Superior de Guerra e tece duras críticas aos militares, que ao seu entendimento, rompe com sua história que era sempre de aproximar-se do povo. Honório torna-se ativo opositor ao generalismo presidencial, pois mais uma vez na história do Brasil os interesses do povo foram descartados em prol dos interesses da elite. O nacionalismo liberal, como fio condutor do pensamento honoriano, ganha força para identificar o atraso do país durante o regime militar.

$\mathrm{O}$ autor de Política Externa e o interesse nacional foi um contumaz defensor da Política Externa Independente (PEI), criada durante a presidência de Jânio Quadros.

Pretendemos recuperar a problemática central dessa discussão que remonta ao rompimento militar com a PEI, que foi dominante nas presidências de Jânio Quadros e João Goulart e posteriormente substituída pelo total alinhamento com os EUA durante o Governo Castelo Branco e de seu Ministro das Relações Exteriores: Vasco Leitão da Cunha. Em seus artigos Honório expõe o princípio que deveria nortear a política externa de um país, ou seja, a procura por sua maior autonomia internacional e a aproximação com os países que mantinham uma diplomacia em consonância com o Brasil.

\section{1 - O governo militar e a crítica honoriana ao "generalismo presidencial"}

Em Conciliação e reforma no Brasil, o intelectual carioca argumenta a respeito da situação política que o país vivenciava após o golpe militar, diz que:

É um imperativo de nossa época agônica ganhar novas perspectivas no reexame do passado, desfazendo mitos, tendo o senso da falência da tradição e mostrando a necessidade da ousadia e da novidade na concepção política do presente e do futuro. (...) A visão retrospectiva deve servir para mostrar que 
certas feições características de nossa história não são nem acessórias nem fortuitas, pois estão enraizadas no nosso passado. (grifos nosso). (Rodrigues, 1965: 11).

A citação acima serve para apontar o posicionamento de José Honório Rodrigues no quadro político e social criado pelo Golpe Militar de 1964 e a posição crítica e contrária que ele assumiu contra o regime instituído pelos militares. A política no Brasil a partir de então é de caráter conservador, porque procura sua justificação no passado. As explicações para a ação institucional estão arraigadas numa sociedade que procura princípios de poder que beneficiam os setores da burguesia. Assim, pretendemos destacar aqui a crítica de José Honório Rodrigues ao regime militar, seu nacionalismo liberal (fonte de suas críticas ao governo) e seu posicionamento que, nesse aspecto, encontra-se em consonância com o de outros críticos ao regime - como Florestan Fernandes.

Se procurarmos identificar como José Honório Rodrigues traça o quadro político-social do Brasil a partir de 31 de março de 1964, encontramos uma visão contundente com relação ao que ele denominava "generalismo presidencial", cuja definição seria: um ação política contra-revolucionária, de defesa intransigente do status quo, do capitalismo brasileiro, com base fortemente antinacionalista, sendo que "defende as multinacionais e a desnacionalização da empresa brasileira" (Rodrigues, 1982: 161).

O poder também tinha características de um regime absolutista, porque estava centralizado no Poder Executivo, da mesma forma que ocorria na monarquia absoluta, "anticonstitucional e anti-representativa". Era um poder. "colonialista" porque tentava colonizar o povo brasileiro, considerado como menor e carente de tutela. Essa imposição que limita a autonomia do povo e os princípios democráticos do Estado recebeu críticas de Honório. Segundo o autor de Conciliação e reforma no Brasil:

Os militares não só concentram o poder, desprezando a velha regra democrática da separação dos poderes, como abusam como quer, sem limites de seus poderes de força, pois usam o poder militar para tirar para satisfação de seus propósitos nacionais ou pessoais. Só o absolutismo de origem colonial e exercido na fase autoritária de D. Pedro I, como excrescência do antigo regime, é capaz do uso irresponsável dos poderes do governo, submetido e tolerado o Legislativo e submisso ameaçado e dócil o Judiciário, formado agora por 
homens escolhido pela Contra-Revolução. (...) O absolutismo é irmão político do colonialismo, para ele o povo é incapaz, merece ser tutelado, deve ser sacrificado ainda que a cota de crueza seja alta. (Rodrigues, 1982: 162).

Para os apreciadores da prática descrita por José Honório, a sociedade perde seus poderes políticos e torna-se dependente de um Estado após a instituição de um regime político ditatorial e antidemocrático. Nesse sentido, existe um antagonismo entre a soberania nacional e as "prerrogativas dos generais presidentes" (Rodrigues, 1982: 162). A soberania popular é usurpada pela soberania dos generais presidentes, que agem pelo direito divino, não pelo direito da força, que, por conter as relações sociais por meio da violência, controla o Estado e tem a possibilidade da escolha dos seus sucessores.

Ainda segundo José Honório:

Donde retiram os generais-presidentes a autoridade para assim confiscar os poderes na Nação? Na força, mas a força não é um poder político; é um instrumento material, físico, auxiliar, e que deve sempre estar á disposição de todos os poderes e por isso é essencial e constitucionalmente obediente. Infelizmente a sociedade brasileira vem sendo governada por um Poder Executivo que entende que ele é a força material, e que a força é a rainha do mundo. O Poder Executivo, sabe-se no Brasil desde a Maioridade, é um poder, como o Legislativo e o Judiciário, subalterno às leis. Cada ato de um poder sem força obrigatória em si mesmo, sem dependência de outro poder. (Rodrigues, 1982: 163).

A usurpação dos princípios de um Estado democrático liberal, da forma como era organizado o poder no Brasil, caracteriza o regime militar como contrário à base de organização da ordem republicana. A defesa de Honório, que lhe parecia incompatível com o governo militar, é por um liberalismo político que deixava de existir no país. Considerava haver total incompatibilidade entre os regimes autoritários e a expressão política do liberalismo. Ficava evidente que o "generalismo presidencial" era o "imperialismo dos generais" (Rodrigues, 1982). Existia, nesse período, “o abuso dos militares, o predomínio da força sobre o direito, a tutela sobre o povo, o desapreço às liberdades públicas e individuais, e a recolonização do povo.” (Rodrigues, 1982: 
165). A ação dos militares pregava uma imagem de que o povo era despreparado e necessitava de alguém para agir em seu nome.

José Honório colocava-se como confesso defensor do liberalismo político. Tinha uma prática que representava "a mais antiga e atual aspiração do povo" (Rodrigues, 1982), ou seja, usurpava as formas legítimas de organização popular: a liberdade política e a garantia dos direitos civis. No caso da ditadura militar no Brasil, o intelectual carioca expõe que:

Os militares não escondem o caráter ditatorial do governo com o rodízio dos ditadores, pois ele é generalizado em toda parte, nos regimes comunistas e militares; nem a existência de assembléias e judiciários limitados no seu poder ou submissos, pois igualmente os tem a União Soviética e seus parceiros, a China, a Nicarágua e Uganda. O partido oficial único, ou os dois Partidos oficiais dão apenas o caráter atual às ditaduras comunistas e militares. Uma ditadura não deixa de ser ditadura porque os ditadores se revezam, se autoescolhendo no poder, e escolhendo seus auxiliares. (Rodrigues, 1982: 166).

A possibilidade de decisão política através do voto foi anulada pelo regime militar, além disso, a ordem institucional, no sentido do funcionamento de uma "democracia liberal" (Schumpeter, 1984), também fora extinta. Esse conjunto de particularidades vinculava ao regime um caso típico de organização política que levou ao "esvaziamento da democracia". (Losurdo, 2004). Cabe destacar que durante os anos do governo militar foram abolidas as possibilidades de voto para presidente da República e para governador de Estado, o que apenas voltou a ser utilizado em 1982 e somente em 1989 para o caso da presidência.

O regime militar, em meio a todas as medidas colocadas em prática durante a sua existência - abolição dos partidos políticos (com permissão somente para dois atuarem), eleições para presidentes e governadores transformadas em indiretas, fechamento do Congresso em duas ocasiões, entre outros - se sustentou com base nas eleições proporcionais, que não foram suspensas. ${ }^{103}$ Os candidatos se apresentaram com suas propostas e os eleitores aceitaram suas atribuições e escolheram seus representantes nas Câmaras federais, estaduais e municipais. Com a instituição eleitoral já bem estabelecida, o voto pôde servir como "garantia a legitimidade do regime." (Canêdo, 2003: 516).

${ }^{103}$ Para melhor entendimento desses fatos ver: Fausto (1998) e Mota (2009) 
Compreende-se que avaliar a condição de uma ordem democrática pela possibilidade ou não do voto é algo limitante, quando a reflexão feita é a respeito de um contexto político e social como fora o momento pós golpe de 1964, em que existiram muitos aspectos que estimulavam a insatisfação de José Honório, que se posicionava contrariamente aos militares. Nesse sentido, são relevantes os comentários do intelectual italiano Domenico Losurdo:

No centro da ideologia hoje dominante há um mito, chamado a glorificar o

Ocidente e, em particular, seu país-guia. É o mito segundo o qual o liberalismo teria gradualmente se transformado, por um impulso puramente interno, em democracia, e numa democracia cada vez mais ampla e mais rica. Para nos darmos conta de que se trata de um mito, basta uma simples reflexão. Da democracia como hoje a entendemos, faz parte em qualquer caso o sufrágio universal, cujo advento foi por muito tempo impossibilitado pelas cláusulas de exclusão estabelecidas pela tradição liberal em detrimento dos povos coloniais e e não proprietários. E estas cláusulas foram por muito tempo justificadas, assimilando os excluídos a "bestas de carga", a "instrumentos de trabalho", a "máquinas bípedes" ou, na melhor das hipóteses, a "crianças" (Losurdo, 2004: 12).

Esse impulso em que o reino da democracia flui tranquilamente, como um sopro do próprio devir do sistema liberal, não funciona organicamente no Brasil. Nesse caso, a ruptura e o distanciamento entre "Poder e Sociedade", ganha contornos dramáticos nos anos do governo militar. O autor de Conciliação e reforma no Brasil argumenta a respeito da enorme dificuldade de o país ter esse elo, ainda que compreenda que a sua existência é fundamental para qualquer sociedade que reivindica para si a condição de democrática, segundo Honório:

A divisão entre o Poder e a Sociedade manifesta-se especialmente pela estabilidade da estrutura e a instabilidade governamental, pelo desequilíbrio entre a população representada no Poder e a mantida na periferia, pela não integração à sociedade nacional de vastas camadas da população, pelo desequilíbrio no crescimento econômico nacional e setorial, pelos desajustamentos regionais. A não incorporação de mais da metade da população aos benefícios da civilização revela a esterilidade dos Partidos e o esgotamento das lideranças. Uns e outros se sucedem no comando ineficiente e incapaz, levando sempre o país ao xeque-mate político, ameaçando a coexistência da 
liderança com o povo, dos partidos com o povo, e por fim, ainda mais sombriamente, do povo com a nação. (Rodrigues, 1965: 237).

Os Partidos pouco atendiam às necessidades dos setores subalternos, tendo muito mais uma função classista e preocupando-se com questões comezinhas, restritas aos próprios interesses pessoais e partidários ${ }^{104}$. O progresso econômico e a integração social constituem há muito tempo o principal problema político e também o menos cuidado. Para os representantes partidários, a conciliação "foi sempre um objetivo e nunca um método.” (Rodrigues, 1965). Honório explica que:

A conciliação, em vez de ser um acordo, um compromisso de concessões mútuas, visando a fins programáticos econômicos sociais que trariam efetivas melhoras democráticas, tornou-se um objetivo, um fim em si mesmo, para benefícios pessoais e partidários. Por isso a conciliação formal, aparando apenas divergências pessoais partidárias, foi sempre, no Brasil, a expressão mais finória do subdesenvolvimento político. Era, enfim, uma política avariada e de Partidos avariados, tão avariados quanto à estrutura econômica e social de que era expressão. (Rodrigues, 1965: 238).

Em síntese o "generalismo presidencial", como organização republicana durante o governo militar, foi muito mais opressor e cruento do que integrador e incruento. Os militares, que se alternavam com um poder de "César"105" (Rodrigues, 1965), aliados que estavam a setores da burguesia brasileira, foram os responsáveis por atos que "aterrorizaram a nação", ao longo da tutela que impingiram a sociedade. A respeito Octávio Ianni, afirma que:

Desde que se instalou amplamente no poder estatal, mediatizada pela colaboração e associação dos latifundiários, setores da igreja, tecnocracia civil e

\footnotetext{
${ }^{104}$ O sociólogo Octávio Ianni, a respeito da função dos partidos políticos durante o Governo Militar, argumenta que: "É necessário explícitar um aspecto fundamental do militarismo que toma conta do país a partir de 1964. O que esta em questão nessa época é a ostensiva entrada de militares no processo político e no aparelho estatal, de modo a realizar uma eficaz recuperação do Estado burguês em crise. Trata-se de instaurar, por via militar, as condições de "ordem e progresso"; ou "segurança e desenvolvimento", que a burguesia não estava em condições de criar por meio dos partidos políticos. (...) Essa medida freou os avanços na ordem institucional burguesa que as lutas de classes faziam avançar no Brasil." (Ianni, 2004: 289).

${ }^{105}$ José Honório vinculava essa ideia de "César" ao poder exercido pela instituição militar, poder esse acumulado ao longo dos anos em que militares encastelaram-se no poder. A respeito dos acontecimentos políticos decorrentes de um "Cesar", no controle do sistema político, Antonio Gramsci designou esse sistema de cesarismo. Segundo o pensador sardo: "podemos dizer que o cesarismo exprime uma situação em que as forças em luta se equilibram de um modo catastrófico, e que a continuação da luta só poderá se dar com a destruição recíproca dos setores em disputa.”(Gramsci, 1992: 67).
} 
militar e outras categorias sociais, a grande burguesia conseguiu instalar a sua ditadura sem aparecer como a classe ditatorial. Tudo parece resumir-se e desvanecer-se na ditadura militar. Na prática, foi a própria burguesia que inspirou ou comandou a contra-revolução burguesa inspirada pelo Golpe de Estado de 1964 e a ditadura criada desde essa data. Fez prevalecer a proposta reacionária, antidemocrática, fascistóide, que vinha propondo e ensaiando desde anos anteriores. Nem a burguesia imperialista, nem a nativa têm compromissos com a democracia, (Ianni, 2004: 295).

Além do já mencionado problema da usurpação dos direitos do povo, exemplificado pela limitação das eleições, e do distanciamento entre "Poder e Sociedade", temos a situação de que a instituição militar passava por um momento de enorme contradição, se comparada às suas atividades ao longo da história do Brasil. José Honório comenta que:

Desde 64, o personalismo representado pelo "generalismo" tem impedido uma atuação maior do Parlamento. Tivemos o tenentismo, tivemos o coronelismo e agora estamos vivendo, desde 64, numa situação que tenho conceituado como generalismo, quer dizer, só pode ser presidente da República general de quatro estrelas. Mas acho que a fase do generalismo está em seu momento outonal. Temos de encontrar uma solução na qual os militares deixem de representar o papel predominante na vida política brasileira. Eles têm de se retirar normalmente e continuar sendo o apoio da Nação. Ao dizer isto, não estou atacando as Forças Armadas ou algum general pessoalmente. Estou apenas fazendo uma interpretação histórica de uma instituição. A instituição é permanente e as pessoas passam. Se alguns generais abusam, a verdade é que nem por isso as Forças Armadas deixam de estar ligadas à História do Brasil desde a independência com enormes serviços ao País. (Rodrigues, 1980: 125).

O posicionamento crítico de José Honório Rodrigues com relação ao governo militar aponta para a faceta democrática do intelectual carioca. Defensor das "aspirações legítimas do povo" no que diz respeito ao funcionamento da "sociedade de direito", Honório propõe a interrupção do governo que, ao seu entendimento, "trava qualquer possibilidade de conquistas sociais" (Rodrigues, 1965: 240). Com seus escritos a respeito da sociedade brasileira sob tutela militar concentrados entre os anos de $1964 \mathrm{e}$ 1982, mostra o quanto a reforma social e democrática no Brasil não foi meta do "generalismo presidencial". 
O ideário nacionalista, que pauta as avaliações do intelectual carioca, é externado para destacar o arbítrio sofrido pelo povo durante os anos de "ditadura militar". Para ele, o momento exigia que fosse formada uma ampla frente nacional progressista, capaz de desfraldar as reformas de cunho nacional tão almejadas pelo povo, que clamava por uma reforma social. O pensador carioca afirmava que:

A reforma social e econômica pode ser feita no Brasil dentro do regime democrático, sem luta de classes, devido à profunda humanidade e à tolerância que caracteriza o nosso povo. Com um sistema democrático vigiado e tutelado isso não é possível, pois a reforma deve ser o fruto do debate amplo, da manifestação livre e espontânea das aspirações de todos os grupos, das divergências, da agitação, e não da discriminação, da exclusão, das comissões de inquérito e do militarismo. Nem pode ser a concessão que certos grupos, ou certos Estados mais desenvolvidos imponham aos mais pobres e menos desenvolvidos, os do centro aos da periferia. É possível o caminho pacífico e conciliador substancial que o radicalismo de esquerda, provocando a direita, atemorizando o centro, tornou mais longo. Toda verdade tem seu momento histórico, por isso a Reforma virá, mais tarde ou mais cedo, logo que se recuperem os meios de ação política e esta se submeta à vontade popular. (Rodrigues, 1965: 242).

Parece evidente que para José Honório Rodrigues, não apenas os militares instituíram um regime "democrático tutelado e vigiado", mas também os representantes do "radicalismo de esquerda" foram responsáveis por dificultar a "Reforma" que atendesse os interesses do povo. A instituição de uma política de desenvolvimento, colocada como uma aspiração nacional necessita de "um conjunto de ajustamentos estruturais e deve ser feita em proveito do povo". (Rodrigues, 1965: 243) e conclui que:

A defesa da Reforma não é uma bandeira de classe, mas uma bandeira nacional e por isso não cabe à classe média comandar o processo, como muitos intérpretes do movimento de abril de 1964 parecem desejar; como não compete também isoladamente a nenhuma outra classe, mas a uma ampla frente nacional progressista. Também não pertence aos Estados desenvolvidos ou metropolitanos impor aos demais, as "colônias", as medidas que julgam necessárias. A Reforma não é um dogma, nem um preconceito; é uma necessidade econômica e um imperativo moral. (Rodrigues, 1965: 243). 
Tendo em vista essa defesa dos valores nacionalistas supostamente presente em setores da sociedade e, principalmente, a crença de que os rumos da ditadura militar seriam modificados devido a urgência moral, José Honório Rodrigues escreve em setembro de 1964 sua avaliação do governo militar, em que "já se passaram mais de 150 dias e o governo militar mais puniu do que construiu" (Rodrigues, 1965). Ele não identificou nenhuma reforma substancial que visasse à integração nacional. Evidentemente que é difícil estabelecer uma avaliação de maior amplitude no calor dos acontecimentos, porém, cabe destacar que existe uma tendência a creditar aos militares a capacidade de modificar os rumos daquele governo, até ali nitidamente arbitrário, pois a "Reforma virá, mais cedo ou mais tarde, logo que o governo recuperar os meios de ação política que submeta à vontade popular”. (Rodrigues, 1965: 244).

No nosso entendimento, o que falta à avaliação de José Honório, na passagem aqui mencionada, é compreender que a liderança militar designa uma ação que promove o interesse de determinada classe, ou seja, de uma burguesia que, assessorada pela tecnocracia, procura colocar em prática um processo de desenvolvimento econômico num Estado tutelado ${ }^{106}$.

Segundo Florestan Fernandes:

A tendência em direção a militarização do estado e da política não decorre da "modernização dos exércitos" e tampouco é consequência de uma decisão interna dos militares imposta pela violência em nome dos interesses das forças armadas. A ditadura militar surge ou está surgindo, em sua nova forma, como um mecanismo de autodefesa política de uma complexa situação de interesses, criada pelo capitalismo dependente, num período de crise e de reorganização na América Latina. $\mathrm{O}$ exército não é um agente político, que trabalhe para si próprio (como uma categoria social), ou para um setor particular da sociedade (como estrato burocrático das classes médias "tradicionais" ou "modernas"). (Fernandes, 1977: 105).

Para o grande sociólogo, esse contexto instituído pelo estágio do capitalismo dependente encontra no exército uma instituição com capacidade de catalisar e dinamizar o processo de aceleração da "revolução burguesa" em curso. Como

\footnotetext{
${ }^{106}$ Em 1964: A conquista do Estado, Rene Dreyfuss, explica que: "Os tecno-empresários formaram, com outros diretores e proprietários de interesses multinacionais e associados, um bloco econômico burguês modernizante-conservador, o qual se opôs a estrutura econômica oligárquico-industrial e ao regime político populista. Esses tecno-empresários tornar-se-iam figuras centrais da reação burguesa contra o renascimento das forças populares do início da década de sessenta, assim como articuladores-chave de sua classe na luta pelo poder do Estado." (Dreyfuss, 1986: 73).
} 
instituição de ação organizada e estratégica, seu papel "na autodefesa política" visa consolidar os interesses privados dominantes. Ainda segundo Florestan, um aspecto deve ser destacado na conjuntura de um Estado que sofre um golpe militar:

O golpe de estado militar apresenta entre seus aspectos um que vale ser destacado: os golpes militares envolvem um tipo de ditadura que é a instituição de "uma ditadura de classe". Considerando-se este aspecto, existe pequena diferença entre estes regimes e as precedentes formas "democráticas" de governo. Na realidade, as formas "democráticas" de governos precedentes sempre encorajaram, de modo dissimulado, ainda que ocasionalmente com apoio popular, uma concentração de poder social extremamente elevada. Portanto, elas eram, realmente, um sistema flexível de opressão e de dominação autoritária, através do qual as classes altas e alguns círculos privilegiados das classes médias monopolizavam o poder politicamente organizado, o controle do estado e os benefícios do crescimento econômico e cultural. (Fernandes, 1977: 106).

Percebe-se que, segundo Florestan Fernandes, nos governos que antecederam ao golpe militar, por não representarem um sistema "de fato" democrático $^{107}$, houve condicionantes para a concentração de poder. Isso levou à radicalização da prática centralizadora, no que concerne ao golpe de 1964, recebendo maior impulso devido aos anseios da burguesia representante do "capitalismo monopolista" (Fernandes, 1977). Todavia, com os militares, a ação, além de ser mantido o aspecto antidemocrático do governo, o caráter "violento" ganha maior espaço, em certo sentido, isso pode ser compreendido pelo caráter doutrinário da própria instituição. O autor de Revolução burguesa no Brasil argumenta que:

Sob a ditadura militar somente a concentração de poder veio a ser mais rígida, violenta e sistemática, permanecendo iguais todas as demais condições. Por outro lado, como efeito dessa mudança, a opressão tornou-se aberta e desmascarada. Qualquer dissimulação ou flexibilidade "democrática" tornou-se desnecessária, pois a margem de tolerância para com a dissensão ou mesmo o consenso "ritual” foi reduzida ao mínimo. (Fernandes, 197: 106).

Essa trajetória das relações políticas sociais no Brasil, que levou a um processo de radicalização "antidemocrática" capitaneado pelos militares, arrefeceu o

${ }^{107}$ A respeito das limitações do sistema democrático brasileiro no período de 1945 a 1964 ver: Weffort (1986). 
contexto das lutas de classes, que ganhou maior dimensão devido à ampliação dos interesses dos representantes do "capitalismo monopolista" (Fernandes, 1977 e 2006).

Para José Honório, esse processo explicitado por Florestan Fernandes também encontra seu movimento embrionário no governo anterior. No entanto, a argumentação honoriana é crítica ao "populismo irresponsável" que, segundo sua avaliação, pautou o governo de João Goulart ${ }^{108}$. O populismo ${ }^{109}$ constitui-se como a grande problemática do período político posterior à $2^{\mathrm{a}}$ Guerra Mundial e trouxe uma instabilidade, pois insuflou as massas sem nada oferecer de forma contundente para melhoria de sua condição de vida. O nacionalismo, então identificado com o populismo de caráter liberal, tal como defendido pelo intelectual carioca, não se coaduna com as premissas do populismo, sendo esse a expressão de uma "nova" forma de manipulação das elites, que mereceu palavras duras de Honório:

A expressão nova foi o Populismo, uma espécie de primitivismo político que infestou os Estados Unidos no fim do século passado e reviveu em toda a América Latina após a $2^{\mathrm{a}}$ Guerra Mundial. O populismo trabalhista transformou-se num instrumento de agitação irresponsável, de meio desordenado de degradação da política e dos políticos. Pela própria agitação que alimentou tornou-se vulnerável e inconsequente. A República parecia existir para ser agitada com a lama das retaliações, das hostilidades e das desordens. $\mathrm{O}$ populismo não chegou a ser um partido, foi à ala negra de vários Partidos e foi também um obstáculo ao crescimento ordenado e eficiente. Ao seu lado viveu um oportunismo carreirista e, se um e outro defendiam as reformas, criavam tal espírito de hostilidade que era difícil trazer para o seu lado setores flutuantes e indecisos, especialmente certos setores das classes médias que teriam interesse em aliar-se às correntes populares. (Rodrigues, 1965: 239).

\footnotetext{
108 Acreditamos ser válido destacar que após a renúncia de Jânio Quadros os militares já apresentavam uma mobilização na tentativa de não permitir que o vice-presidente assumisse o posto. A respeito Antonio Carlos Peixoto afirma que: "Em 1961, se o golpe de Estado dirigido pelos três ministros militares contra Goulart malogrou, foi porque a hierarquia estava dividida. Um foco de resistência no Rio Grande do Sul funcionou como um pólo de atração para os grupos de oposição dentro do Exército. As Forças Armadas estavam profundamente divididas. (...) Finalmente, a intervenção de 1964 também apresentou as mesmas características que as duas anteriores. A corrente nacionalista, apesar de presente no seio da hierarquia, não pode impedir que o conjunto da hierarquia, que refletia a opinião da maioria das Forças Armadas, derrubasse Goulart." (Peixoto, 10980: 113)

${ }^{109}$ Em obra clássica a respeito do tema, Francisco Weffort explica que: "O populismo no Brasil e na Argentina.apresenta características que são de fundamental importância para nossos objetivos, ou seja, em ambos os casos o surgimento política das classes populares se encontra essencialmente vinculado à formação de governo e movimentos sociais e constitutivos do que poderíamos designar como um sistema populista; estrutura institucional de tipo autoritário e semicorporativa, orientação política de tendência nacionalista, antiliberal e antioligárquica; orientação econômica de tendência nacionalista $e$ industrialista; composição social policlassista mas com apoio majoritário das classes populares." (Weffort, 1986: 85)
} 
Com ações que pregavam a "hostilidade e a desordem", o populismo estava longe de contemplar os valores do nacionalismo liberal de José Honório. Não existiriam, na ação política dos "dirigentes populistas", medidas que colaborassem para que o país aderisse ao "caminho do americanismo". Não sendo capaz de atrair os setores das classes médias que estivessem próximos aos interesses das "correntes populares", o populismo não conseguiu engendrar forças políticas conciliadoras com o povo. Deve-se destacar que a crítica incisiva feita pelo intelectual carioca, aos representantes do "populismo trabalhista", estava destinada a João Goulart ${ }^{110}$.

Para o autor de Aspirações Nacionais, essa mazela que atingia os partidos levava à falta de crescimento ordenado e eficiente, o que ganhará contornos trágicos com a ação dos militares. Da mesma, forma que ocorreu com os representantes do "populismo trabalhista", os militares foram alvo de críticas por parte do intelectual carioca.

Instituição que deveria estar a serviço da Nação, ao lado do povo, o exército era visto como de fundamental importância para a organização do Estado. Para o Honório: "um exército disciplinado, que simboliza a força nacional, está a serviço da nação e de seu povo, e não de personagens que aterrorizam a nação." (Rodrigues, 1982: $163)$.

Representante da "força nacional", os militares em general, e em particular o exército, apresentava essa particularidade durante o período do movimento tenentista $^{111}$, pois naquele movimento existia a necessidade de instituir um governo que tivesse em consonância com as reivindicações e aspirações do povo. Segundo o autor de Aspirações Nacionais:

\footnotetext{
${ }^{110}$ Cabe destacar a interpretação de Octávio Ianni a respeito do período de 1945-1964: "Em 1945-64, a sociedade brasileira viveu uma época de razoável progresso democrático. O povo alargou a sua participação no processo político, em termos de eleições, representantes no Legislativo, agilização de sindicatos e partidos políticos, debates e organizações que ampliavam as estruturas políticas intermediárias criadas pela Assembléia Nacional Constituinte que elaborou a Constituição de 1946. É verdade que as instituições jurídicas-políticas reaproveitadas da ditadura do Estado Novo (1937-1945), e as criadas desde 1946, favoreciam uma democracia burguesa razoavelmente autoritária. Mas os operários urbanos e rurais, camponeses, empregados, funcionários, profissionais liberais, intelectuais, estudantes e outros setores desenvolveram atividades sociais, políticas e culturais que implicaram o avanço do processo democrático." (Ianni, 2004: 273).

${ }^{111}$ Segundo Boris Fausto: "O tenentismo produziu uma inflexão na vida política brasileira e deixou uma influência persistente, após ter desaparecido de cena em 1934 como movimento organizado. Nos anos vinte, tornou-se, para todas as camadas intermediárias e populares da sociedade, o grande depositário das esperanças de uma alteração da ordem vigente. Não há razões para se pensar que a massa operária, por exemplo - nas condições de um movimento operário em depressão - deixasse de ser tocada por suas façanhas." (Fausto, 1997: 411).
} 
O tenentismo foi um movimento genuíno da mocidade militar identificada com as aspirações populares, mas sem uma ideologia definida. (...) O tenentismo nascido do mal-estar da pequena burguesia sem ainda haver atingido o ápice do seu desenvolvimento, refletia obrigatoriamente nas suas linhas gerais a ausência de espírito associativo entre as novas camadas brasileiras, a carência de uma comunhão de aspirações e de interesses dos habitantes dos centros urbanos. Por isso sua doutrina só se definiu pouco a pouco, com o progresso crescente da revolução, através do contrachoque das correntes partidárias. (...) O fato básico, contudo, é que o Governo Provisório sempre procurou equilibrar as forças de ação e reação, as oligarquias e o tenentismo. (Rodrigues, 1985: 90).

O tenentismo quebrava a tradição de poder das oligarquias, instituindo relações que procuravam aproximar "Poder e Sociedade". A tentativa básica era incorporar à sociedade valores que pudessem reproduzir os "verdadeiros interesses nacionais" (Rodrigues, 1982: 167). O exército, mesmo que limitado à parcela envolvida no tenentismo, sempre procurou equilibrar as forças conflitantes. O seu papel histórico é de defensor do nacionalismo e dos "valores patrióticos". Honório comenta sobre o assunto que:

Penso em ser mais fácil discernir nas Forças Armadas o patriotismo, uma virtude cívica, uma inclinação efetiva à nossa terra e à nossa gente, do que uma posição nacionalista bem definida. O patriotismo não é privativo de qualquer classe, de qualquer doutrina. Mas os patriotas divergem não só quanto às doutrinas, mas quanto os métodos que devem servir à pátria. (Rodrigues, 1986: 145).

Fica evidente que essa postura do Exército sofre uma grande mudança a partir de 1964. O golpe militar e a instituição do "generalismo presidencial" romperam com a tradição dos militares, que sempre procurou segundo José Honório, agregar algo ao povo e se manter na defesa dos interesses nacionais. O momento de violência instalado com os militares, e que sofre um aumento substancial durante o governo do Gal. Médici ${ }^{112}$, foi a marca registrada das Forças Armadas no Brasil a partir de 1964. Segundo o intelectual carioca:

\footnotetext{
${ }^{112}$ O professor Ângelo Del Vecchio tece os seguintes comentários a respeito do "terror" instituído durante o governo do Gal. Emílio Garrastazu Médici (1969-1974): "Em janeiro de 1970, entrou em funcionamento o "Sistema de Segurança Interna do País"; os Centros de Informação de Segurança do Exército (CIE), da Aeronáutica (Cisa) e da Marinha (Cenimar) começaram a operar e as Divisões de
} 
O general-presidente escolhe tudo, governadores, senadores, e até a maioria das Câmaras Estaduais e de Vereadores, quando elas oferecem risco de discordância. (...) Esta a situação política do generalismo presidencial. Ela se caracteriza por uma profunda abstenção e apatia por tudo que seja político. Os modelos histórico-políticos do Brasil foram a crueza, a apatia, a conciliação e o consentimento. Os dois últimos inexistem desde 1964, e os dois primeiros predominam incólumes e sem alternância com os dois outros, como foi comum ao processo histórico brasileiro. Nestes últimos anos o Estado está contra o indivíduo, os deveres valem tudo contra os direitos, e a imposição sobre a convivência. Não se convive, se sobrevive. (Rodrigues, 1982: 171).

A postura adotada por José Honório Rodrigues frente aos acontecimentos que levaram à instituição do governo militar realça o caráter nacionalista-liberal do projeto de desenvolvimento que a sociedade brasileira deveria tomar. Como representante de uma linhagem do liberalismo político, ele acreditava que essa deveria ser a forma de prática política das lideranças conciliadores na procura da ordem democrática. Todavia, o intelectual carioca considera o golpe militar como uma bravata dos militares, levando ao corrompimento da organização dos três poderes e instituindo, “o imperialismo dos generais" (Rodrigues, 1982). As assertivas de Honório nos parecem com um aspecto interpretativo falho. $\mathrm{O}$ golpe, ao seu entendimento, não é visto como produto da colaboração e articulação de setores organizados da sociedade civil. Para além do "populismo infantil" de João Goulart, o intelectual carioca analisa que o presidente fora deposto pelos opositores colocava em prática um conjunto de medidas que, supostamente, traria estabilidade e abriria caminho para a introdução do comunismo no Brasil. ${ }^{113} \mathrm{~A}$ impossibilidade do funcionamento das instituições

Informação dos Ministérios Civis foram regulamentadas; e o modelo originário da Operação Bandeirante (OBAN), de São Paulo generalizou-se para o país, dando lugar ao "Sistema Doi-Codi". Não tardou para que esse aparato recém constituído entrasse em confronto com os partidários da contestação armada ao regime. Ambos os lados progrediram, rapidamente para ações decisivas, e a violência estatal se espraiou em velocidade e proporções superiores às próprias atividades de seus oponentes civis." (Del Vecchio, 2006: 140).

${ }^{113}$ Na obra clássica a respeito, 1964: A conquista do Estado (ação política, poder e golpe de classe), Rene Armand Dreifuss, explica que: "A 2 de abril de 1964, a burguesia comemorou a deposição do Presidente João Goulart com um gigantesca marcha de famílias pelas rua do Rio de Janeiro, um acontecimento cujos organizadores aguardavam com ansiedade há mais de uma semana. Na hora marcada para o início da marcha, a Avenida Rio Branco continha um mar de faixas contra o comunismo, carregadas por uma multidão calculada em oitocentas mil pessoas. Enquanto as multidões percorriam a Avenida Rio Branco, a sucessão presidencial era extensivamente discutida. Os empresários que assistiam à Marcha do escritório dos IPES no Rio, "contentes com as aclamações e entusiasmo nas ruas e muito satisfeitos com o resultado de seu trabalho anticomunista", conversavam com o Gal. Heitor Herrera, um dos seus elos-chave com os oficiais da ESG, "sobre as qualidades que desejava ver no próximo presidente 
democráticas e a inflexão a práticas autoritárias do governo levaram ao seu rompimento com a Escola Superior de Guerra e, consequentemente, à adoção de uma posição contrária ao regime. No conjunto de discussões a respeito da política externa, está expresso seu total descontentamento com o "generalismo presidencial".

\section{2 - O nacionalismo e a política externa independente: um compromisso ideológico.}

A preocupação com o desenvolvimento já ocupava a política externa brasileira desde a década de 1930, porém nos anos de 1950 e especificamente no governo de Juscelino Kubitschek encontramos uma ênfase maior no nacionalismo desenvolvimentista - ideologia que vai embasar a política interna e, consequentemente, a política externa. Como fonte de produção do ideário nacionalista, o ISEB ${ }^{114}$ (Instituto Superior de Estudos Brasileiros) foi responsável por orientar ideologicamente a forma de desenvolvimento do pensamento nacionalista brasileiro.

A política externa de barganha nacionalista de Juscelino esboçada a partir de 1958 não representava, por sua vez, mera improvisação conjuntural. O desenvolvimento continha em seu bojo determinadas tensões e alternativas. $\mathrm{O}$ nacionalismo e a política externa pautada pelo "interesse nacional" (Elek, 2009) autonomamente expresso eram debatidos e estudados pelo ISEB. Em 1958, o lançamento do livro de Hélio Jaguaribe, $O$ nacionalismo na atualidade brasileira, acirrou o debate do nacionalismo versus entreguismo dentro do instituto. Esse cenário levou a uma cisão que culminou na saída de uma ala do ISEB dos denominados "moderados" (Jaguaribe, Cândido Mota Filho, Cândido Mendes entre outros). No âmbito intelectual que girava em torno das ideias isebianas, José Honório Rodrigues, um desses intelectuais, dava especial ênfase aos estudos sobre o nacionalismo e a política externa.

do Brasil...”.'(Dreifuss, 1986: 420). Outros autores trouxeram informações a respeito da participação de setores civis no golpe militar de 1964, nesse sentido ver: Mota (2009) e Skidmore (1988).

${ }^{114}$ O ISEB foi fundado em 1955, dando continuidade às tradições nacionalistas e progressistas do Grupo de Itatiaia e do Instituto Brasileiro de Economia, Sociologia e Política. Seu movimento editorial, apoiado pelo Ministério da Educação, e defendia basicamente a tese da aliança entre a burguesia nacional e os setores populares para superar o subdesenvolvimento. Helio Jaguaribe, Guerreiro Ramos, Nelson Werneck Sodré, Cândido Mendes, Horácio Lafer, Sérgio Buarque de Holanda, José Honório Rodrigues e San Tiago Dantas eram alguns dos integrantes do Conselho do ISEB. Para maiores detalhes a respeito ver: Jaguaribe (1979), Toledo (1977), Pecaut (1990) e Vale (2006). 
Para o intelectual carioca, a ação da política externa instituída durante o governo de Jânio Quadros ${ }^{115}$ conduziu o Brasil a uma política de ajustamento que "respeita o regionalismo hemisférico, não desvalorize os objetivos intercontinentais, amplie o comércio e as relações políticas." (Rodrigues, 1966: 71). Essa posição passa a ser reflexiva se compararmos com o histórico do país, sempre como coadjuvante nas relações políticas internacionais. Além disso, deve-se considerar que essa condição de subalternidade é resultado de um processo histórico. Como exemplo dessa condição subalterna, o intelectual carioca destaca que:

O Brasil, desde Quadros, não se conforma mais, não aceita, refuga o papel secundário, uma espécie de Vice-Rei que lhe destinou a política norte americana, convencida que era imperativo para os Estados Unidos isolar o hemisfério ocidental americano das demais nações e mantê-lo subordinado a Metrópole real localizada em Washington. Esta posição modesta e irreal para um País como o Brasil atual, malgrado todas suas insuficiências e a incompreensão para com o nacionalismo econômico geraram um ressentimento, que o povo exprimiu na votação dada a Jânio Quadros, e este interpretou com vacilação e dubiedades, mas, na essência, com sagaz intuição. No fundo, é a linha de Domício da Gama que se retoma, com maior desassombro, acrescida da ideia do desenvolvimento econômico, da total liberdade de ação internacional e da ampliação das relações políticas e econômicas. (Rodrigues, 1966: 71).

O posicionamento de José Honório Rodrigues é fruto direto dos acontecimentos posteriores ao golpe militar de 1964. O engajamento adotado pelo historiador, frente aos desígnios pós 31 de março, refletiu-se no engajamento adotado por intelectuais como: Alceu Amoroso Lima, Barbosa Lima Sobrinho, Hermano Alves, Antônio Calado e Paulo de Castro (Mello, 1994: 172), todos críticos ao governo instituído e, principalmente, à "submissão adotada frente aos interesses norteamericano" (Mello, 1994). O apoio da imprensa fez repercutir entre esses intelectuais a necessidade de adotar uma postura que deveria expor a crítica a submissão adotada

\footnotetext{
${ }^{115}$ Segundo Paulo G. Fagundes Vizentini: "Durante a curta e tumultuada gestão de Jânio Quadros (sete meses incompletos), as relações internacionais do Brasil sofreram uma alteração importante com a formulação da Política Externa Independente. Esta não representava uma inovação completa, na medida em que se estruturava como continuidade e aprofundamento da barganha nacionalista de Juscelino e Kubitschek, e da política externa dirigida para apoiar o desenvolvimento industrial. No entanto, a Política Externa Independente era explicada num conjunto de princípios articulados, extrapolava o âmbito regional e abria perspectivas mundiais, ultrapassava as vacilações dos governos anteriores e dava à política externa um perfil e um lugar de destaque na vida nacional." (Vizentini, 1995, 177)
} 
naqueles anos. Estes foram acolhidos pela "Revista Civilização Brasileira", do editor Ênio Silveira, e ali organizaram uma revista de "protesto" a Política Externa do governo civil militar. A reunião da Organização dos Estados Americanos (OEA), no Rio de Janeiro, fez multiplicaram-se esses protestos. Para sistematizá-los, Ênio Silveira criou a revista Política Externa Independente ${ }^{116}$, da qual José Honório Rodrigues foi colaborador.

Os temas centrais da Revista de Política Externa Independente visavam a identificar qual deveria ser a política externa adotada pelo Estado brasileiro, a fim de procurar superar à histórica dependência do capital norte-americano, no sentido de alcançar a tão propalada autonomia internacional. A proposta, ao entendimento de Honório, apontava para a necessária aproximação com os países africanos e também com aqueles que compunham o bloco socialista.

Para melhor compreensão de suas argumentações, duas obras são fundamentais a respeito da política externa brasileira: Interesse nacional e política externa (1966) e África e Brasil: outro horizonte (1961). Em ambos José Honório procura tematizar a respeito do papel histórico do Brasil no que diz respeito as relações com a África e com os países que compunham o bloco socialista.

\section{3 - A crítica a Política Externa dos Militares}

Ao assumir a presidência da República em abril de 1964, o general Castelo Branco, juntamente com o recém empossado ministro das Relações Exteriores, Vasco Leitão da Cunha ${ }^{117}$, propôs-se a desmantelar os princípios que regiam a Política Externa Independente, tais como o nacionalismo, a base da industrialização brasileira, o ideário da Operação Pan-Americana e a autonomia do Brasil face à divisão bipolar do

\footnotetext{
${ }^{116}$ Com a colaboração de, entre outros, Barbosa Lima Sobrinho, Maria Yedda Linhares, Torquato di Tella, Leo Huberman, Mario Pedroza, Hermano Alves e Paulo Francis. O editorial, de titulação extraída da própria temática desse número, insurgia-se contra a criação da Força Interamericana de Paz, oficialmente responsável pela intervenção dominicana de 1965. O estudo de José Honório Rodrigues aí publicado intitula-se "Brasil e extremo Oriente" e aproxima a política externa independente dos chanceleres Afonso Arinos de Melo Franco e San Thiago Dantas. No ano seguinte, esse mesmo estudo seria publicado em seu livro Interesse nacional e política externa (Mello, 1995: 281).

${ }^{117} \mathrm{Na}$ apresentação do livro Diplomacia em alto mar: depoimento de Vasco Leitão da Cunha ao CPDOC, a socióloga Aspásia Camargo tece os seguintes comentários: "Nascido no dia 2 de setembro de 1903, iníciou a carreira diplomática em 1927. Em 1941 substituiu interinamente Francisco Campos ministro da Justiça do Estado Novo. (...) Após ocupar o cargo de Secretário Geral do Itamaraty durante o governo de Jânio Quadros, foi designado o primeiro embaixador do Brasil em Moscou após o reatamento das relações diplomáticas com a União Soviética. Com o movimento militar de 1964 (grifo nosso), assume a pasta de Ministro das Relações Exteriores." (Camargo, 2003: XXIV).
} 
mundo e a hegemonia norte-americana sobre a América Latina, além da destituição imediata do embaixador do Brasil nos Estados Unidos e a nomeação imediata de Juracy Magalhães.

A modificação expressiva instituída pelo regime ditatorial visava a imprimir novos padrões de conduta no cenário internacional. Para colocar em prática tal intento, a manifestação inicial tinha o objetivo de desarticular a Política Externa Independente ${ }^{118}$, pois segundo os mentores desse "desmonte", não havia uma "utilidade descritiva" para a política externa, face ao contexto bipolar mundialmente desencadeado pela Guerra Fria ${ }^{119}$. Outro aspecto a ser combatido pelos representantes do "generalismo presidencial" (Rodrigues, 1982: 159) seria o nacionalismo, pois sua faceta era amplamente prejudicial ao desenvolvimento econômico no Brasil, já que afugentava o capital estrangeiro. Havia uma oposição à estatização, que obstruía os interesses da burguesia ligada ao capital estrangeiro e o desenvolvimento da livre empresa, e à ruptura de laços afetivos e políticos com Portugal e com o Ocidente, em nome do anticolonialismo. (Cervo, 1995: 333).

Nesse cenário, a obra de José Honório Rodrigues procura se contrapor às propostas instituídas pela cúpula que passou a exercer o papel político no país em abril de 1964. Sua obra surge para polemizar esse quadro de crise instituído pelo golpe, em que os interesses dos grupos próximos ao liberal-nacionalismo que o historiador carioca

\footnotetext{
${ }^{118}$ Durante o governo de João Goulart assumiu a pasta de Ministro das Relações Exteriores San Tiago Dantas que afirmava: "A política exterior independente que encontrei iniciada no Itamaty e procurei desenvolver e sistematizar, não foi concedida como doutrina ou projetada como plano antes de ser vertida para a realidade. Os fatos precederam as ideias. As atitudes, depois de assumidas em face de situações concretas que se depararam à Chancelaria, patentearam uma coerência interna, que permitiu a sua unificação a sua unificação em torno de um pensamento central de governo. (...) Não quer dizer que a sua elaboração tenha sido empírica ou casual. Na origem de cada atitude, na fixação de cada linha de conduta, estava presente uma constante: a consideração exclusiva do interesse do Brasil, visto como um país que aspira ao desenvolvimento e à emancipação econômica e à conciliação histórica entre o regime democrático representativo e uma reforma social capaz de suprimir a opressão da classe trabalhadora pela classe operária. (...) Esse foi, desde o primeiro instante, o princípio gerador da política externa e a razão determinante de sua unidade. Passados alguns meses, em que episódios dramáticos puseram à prova a coerência e a resistência da Chancelaria, o povo brasileiro se deu conta, e todos os países compreenderam, que o Brasil havia fixado uma posição internacional, e que essa posição não era atribuída nem provisória, mas correspondia a interesses e aspirações permanentes da nacionalidade". (Dantas, 2006: 6).

${ }^{119}$ Com as condições sui generis da sociedade brasileira pós-golpe militar de 1964, acreditamos que a definição de Eric Hobsbawm a respeito do evento é bem elucidativa: "A Guerra Fria entre Estados Unidos e União Soviética, que dominou o cenário internacional na segunda metade do Breve Século XX, foi sem dúvida um episódio sem similar na história da humanidade. Gerações inteiras se criaram à sombra de batalhas nucleares globais que, acreditava-se firmemente, podiam estourar a qualquer momento, e devastar a humanidade. Na verdade, mesmo os que não acreditavam que qualquer um dos lados pretendia atacar o outro achavam difícil não ser pessimistas, pois a Lei de Murphy é uma das mais poderosas generalizações sobre as questões humanas." (1995: 224).
} 
defendia foram afetados. Buscava-se no campo intelectual um enfrentamento austero e contundente com o regime.

Logo na apresentação da obra, o autor se posiciona claramente contrário ao espírito conservador e preso às tradições mais arcaicas que imperavam naquele momento (a obra é de 1966). Colocar os legítimos interesses da maioria da população à frente de qualquer interesse dos representantes do "Brasil arcaico" é a grande meta que deve ser defendida pelos que desejam, de fato, lutar "por um futuro melhor". (Rodrigues, 1966: 3). O historiador carioca defende que a missão dos intelectuais, devido à condição de subserviência identificada em setores da elite intelectual, é a de esclarecer o povo sobre o sentido e a significação da política externa para o desenvolvimento nacional. A preocupação com a situação, que o povo pode ser lançado por um governo que o oprime e o impede de externar suas opiniões é outra angústia de José Honório:

O longo silêncio do povo brasileiro, ampliado pelos Governos de exceção, pode levá-lo a mais um dos seus raros momentos de desespero. O povo brasileiro tem sido um reservatório fabuloso de insatisfação e por isso mesmo a intensidade do presente pesa ainda mais sobre a nossa consciência social. O governo, que governa por sonoterapia, indiferente à sangria popular, faz-nos lembrar aquela verdade, dita por Amintore Fanfani ao Presidente Kennedy e que muito o impressionou: "É uma ironia que os comunistas, que acreditam na ditadura, estejam sempre se dirigindo às massas, enquanto o Ocidente, que acredita na democracia, sempre se dirige aos líderes. (...) A atual e catastrófica desintegração do sistema democrático brasileiro e das liberdades e garantias individuais resulta da vitalidade do militarismo. É o fruto da infiltração de ideias difundidas pelo Pentágono na elite militar dos países subdesenvolvidos ou em desenvolvimento. As ideias de segurança em primeiro lugar, da grande subversão, da agressão interna, transformaram a consciência de certos grupos militares. (Rodrigues, 1966: 4).

A obra é fruto das discussões que fora travada nas publicações do período, mas principalmente dentre aqueles que participavam da Revista de Política Externa independente. Além de José Honório Rodrigues, outro que participou da Revista foi San Tiago Dantas, sendo um ativo colaborador dessa revista que circulou entre os anos de 1965-1966. A respeito da participação de San Tiago Dantas a frente do Ministério das Relações Exteriores, Clodoaldo Bueno afirma que: 
San Tiago Dantas foi um democrata. Político moderno e em compasso com o seu próprio tempo. As principais notas observáveis em seus discursos sobre política exterior foram com a preocupação com a manutenção da paz, com o subdesenvolvimento e os desníveis sociais dele decorrentes, e a reivindicação, para o seu país, de participação nas decisões internacionais. (Bueno, 1995: 294).

Sua ação a frente do Ministério das Relações Exteriores foi determinante para a continuidade do período de Afonso Arinos de Melo Franco, chamada para ocupar a pasta no governo de João Goulart, ainda segundo Bueno:

Não só deu continuidade a política de Jânio/Afonso Arinos como se tornou um dos mais importantes formuladores da Política Externa Independente. Esta, segundo ele, não foi um plano estratégico concebido a priori, mas uma atitude, uma maneira de ver e encaminhar os assuntos internacionais, visto como um país que aspira ao desenvolvimento e à emancipação econômica. (Bueno, 1995: 295).

A denominada "desintegração do sistema democrático brasileiro", questionada por José Honório Rodrigues, acabou impingindo mudanças na forma de avaliação e discussão da política externa do país. A vigência da política externa independente do período João Goulart e Jânio Quadros perdeu espaço significativo. Em seu lugar, tivemos uma política pautada pela teoria dos círculos concêntricos ${ }^{120}$ encabeçada por Vasco Leitão da Cunha. Essa mudança foi adotada seguindo a ideia de ruptura com a organização política do governo Jango, em que os militares tinham total aversão à condução da política externa independente e partiram para uma ação de "mudança de rumo". 121

\footnotetext{
${ }^{120}$ Os círculos concêntricos hierarquizavam, sob o prisma econômico, segundo sua mais imediata relevância para o nosso comércio e investimentos - os EUA, a Comunidade Européia e o Japão. O Oriente Médio teria importância em vista de nossa dependência petrolífera, e os países socialistas como mercado complementar. Sob o prisma político, a hierarquização seria mais fluída, já que o valor relevante, além da defesa, seria nossa capacidade de exercer projeção política. Isso priorizaria a América Latina, depois a África, e eventualmente outras partes do mundo subdesenvolvido sobre as quais lográssemos exercer alguma influência. Desse modo, hierarquizaram-se as relações econômicas e políticas. (Melo, 2002: 233).

${ }^{121}$ Segundo o professor Paulo Fagundes Vizentini: "Os princípios da Política Externa Independente, podem ser resumidos nos seguintes pontos: a) Exportações brasileiras para todos os países, inclusive socialistas; b) Defesa do Direito Internacional, da autodeterminação e da não intervenção nos assuntos internos de outros países (aplicados em relação a Cuba); c) Política de paz, desarmamento e coexistência pacífica nas relações internacionais; d) Apóia à descolonização completa de todos os territórios ainda submetidos e e) Formulação autônoma de planos nacionais de desenvolvimento e de encaminhamento da ajuda externa." (Vizentini, 2008: 23).
} 
As iniciativas visavam à contribuição do Brasil para o fortalecimento do Bloco Ocidental, sob a hegemonia norte-americana e, em clara política de barganha, supunha recolher grande incremento de fluxos de capitais e tecnologias, abertura de seu mercado a produtos brasileiros (inclusive industrializados) e ampliação da reserva de mercados na América Latina às empresas que tivesse filiais no Brasil. ${ }^{122}$

Além dos ingredientes ideológicos envolvidos na designada opção pelo Ocidente, Castello Branco fez alusão a outro fator determinante, ao reconhecer, após assumir o governo, que quase só encontrara compromissos com essa área. $\mathrm{O}$ "universalismo" (Vizentini, 2008) da fase anterior não fora traduzido em iniciativas concretas relevantes, nem havia alinhado as posições brasileiras com as teses neutralistas e reivindicatórias do Terceiro Mundo. Nesse cenário, em que a meta era a desarticulação do nacional-desenvolvimentismo que ainda "respirava", foram elaboradas duas frentes de ação, que, no tocante ao continente, compunham a estratégia regional implementada por Castello Branco e por seu grupo de americanistas (Vasco Leitão da Cunha e depois Juracy Magalhães no Ministério das Relações Exteriores; e Roberto Campos e Otávio Bulhões nos ministérios econômicos) de “... eliminar os atritos nas relações entre o Brasil e a potência hegemônica do bloco ocidental para viabilizar a associação dos capitais, dos mercados e da tecnologia, em harmonia com a afinidade política e enquadrar relações interamericanas em esquema funcional mediante a segurança coletiva e o mesmo tipo de vinculações econômicas.” (Bueno, 1992:336).

\section{Segundo Clodoaldo Bueno:}

As iniciativas correspondiam à contribuição do Brasil para o fortalecimento do bloco ocidental, sob hegemonia norte-americana, e supunham recolher, em contrapartida, da parte dos Estados Unidos, grande incremento nos fluxos de capitais e tecnologias, abertura de seu mercado a produtos brasileiros, inclusive industrializados, e ampliação da reserva do mercado latino-americano às filiais brasileiras das empresas estrangeiras. (...) Nos termos da chancelaria brasileira, as relações com os Estados Unidos foram "recolocadas" no eixo das prioridades

\footnotetext{
122 O poder supremo na ordem hemisférica deveria caber aos Estados Unidos. Os demais estados da região não poderiam, contudo, ser tratados como equivalentes entre si, uma vez que são patentes as diferenças que os distinguem em termos de status internacional. Um modo de fazer justiça à estratificação existente seria alcançado, desde que fosse atribuída a condição de sub-liderança às potências médias da região. Considerando-se, inclusive, que os países mais pobres e atrasados são precisamente os mais propensos à subversão, caberia à Argentina, ao Brasil e ao México o dever de assumir, em parcial substituição aos Estados Unidos, uma parcela maior das responsabilidades globais pela manutenção da ordem continental. (Martins, 1975: 59).
} 
em 1964, consolidadas em 1965, para atingirem o nível de excelência em 1966.

(Bueno, 1995: 337).

A prática da política externa dos militares visava criar as condições para o desenvolvimento econômico aliado ao capital internacional. Barreiras de qualquer ordem, principalmente aquelas instituídas pelo Ministério das Relações Exteriores deveriam ser abolidas, o alinhamento com o Bloco Ocidental, pautado pela Guerra Fria, mas também por uma conjuntura interna que identificou no governo militar a possibilidade de crescimento e mobilidade, assessorada e garantida por um Estado que institui limites e coagia setores da oposição ${ }^{123}$.

Clodoaldo Bueno, explica que:

Depois que o governo Johnson aplaudiu a revolução de 1964, o Executivo brasileiro tratou de estreitar imediatamente as relações. Fez ainda, em 1964, 14 ajustes com a Agency for International Development, para cooperações de pequeno vulto, no quadro da Aliança para o Progresso, recebendo até 1965, 650 milhões de dólares. Em 1965 veio a importante missão do senador William Fulbright, o governo brasileiro reescalou suas dívidas com os Estados Unidos, a Europa e o Japão, firmou com os primeiros o acordo de garantia de investimento privado e o de cooperação para usos civis da energia atômica. Além disso, o atrelamento com os Estados Unidos passou pela reformulação da lei de remessas de lucro, imposta a um Congresso parcialmente cassado, pelo pagamento dos acervos da AMFORP e ITT conforme queriam os norte americanos, por concessões a empresas daquele país, por planos de ajustamento econômico e de endividamento consoante os padrões da FMI, por ajustes militares e um acordo aero fotográfico, pela presença, enfim, de um grandioso contingente de especialistas norte-americanos a assessorar as áreas militar e econômica do governo. (Bueno, 1995: 339).

Um vetor dessa mudança de atitude foi o rompimento com Cuba, fato que ocorreu em 13 de maio de 1964, ou seja, exatos 44 dias após a chegada dos militares ao poder. Outro fator que exemplifica o posicionamento do Brasil, naquele

\footnotetext{
${ }^{123}$ O golpe de 1964 é identificado como um movimento que foi articulado pelos setores militares, mas também contou com a presença de setores civis; que defendiam seus interesses, no que diz respeito a ao desenvolvimento do capital local em articulação com o capital internacional. A socióloga Maria de Lourdes Manzini Covre explica que: "Em 1964 a classe dominante rearticula seus compromissos com a Sociedade Civil, cria determinados privilégios para as chamadas classes médias, aciona o processo de exclusão das massas para "financiar" o sócio menor: o capital local" (Covre, 1983: 26).
} 
contexto do regime militar, foi à postura adotada diante da crise da República Dominicana entre abril e agosto de $1965^{124}$. É nesse contexto que José Honório Rodrigues passa a engajar-se intelectualmente nas discussões da política externa independente. As condições de submissão que aceitávamos a partir da tomada de poder pelos militares eram aviltantes se pensarmos em momentos de enfrentamento no que diz respeito a nossa política externa.

O papel de coadjuvante nas relações exteriores era algo já enraizado na sociedade brasileira. Saíamos de um movimento desse setor que vislumbrava a possível mudança dessa lógica quase inabalável ${ }^{125}$. A estrutura arquitetada desde a época imperial condicionava o Brasil ao poder do imperialismo britânico e ao de seu principal concorrente, o francês. Naquele momento, o intuito primordial da sociedade brasileira era manter seu patrimônio territorial e a unidade nacional. As imposições, principalmente dos ingleses, que afetavam a situação econômica do país, poderiam gerar uma desestabilização da principal fonte de recursos que estava associada diretamente ao "tráfico negreiro transatlântico". ${ }^{126}$

A manutenção do tráfico e a forma de burlar das determinações impostas pelos ingleses caracterizaram a política adotada pelo país durante o Segundo Reinado. É inquestionável a supremacia da Inglaterra como centro do capitalismo durante a

\footnotetext{
${ }^{124}$ A respeito da condição subalterna do Brasil pós golpe de 1964, como por exemplo a "Questão Dominicana", Vizentini procura explícitar essa dependência: "Em troca da subordinação a Washington e do abandono da diplomacia desenvolvimentista, o Brasil esperava receber apoio econômico. O chanceler Juracy Magalhães chegou a afirmar que "o que é bom para os Estados Unidos é bom para o Brasil". Como prova da lealdade ao "grande irmão do Norte", o Brasil rompeu relações com Cuba em maio de 1964, num gesto carregado de simbolismo, mostrando que o país eliminava qualquer traço "esquerdista" de sua política. (...) Na sequência dessa linha, a pedido de Washington, enviou tropas à República Dominicana em junho de 1965 sob a bandeira da OEA, com o fim de evitar que a guerra civil daquele país gerasse uma "nova Cuba". A atitude brasileira danificou enormemente a imagem do Brasil na América Latina. Somando-se à crescente projeção da economia brasileira sobre os vizinhos, a intervenção deu conteúdo ao conceito de subimperialismo, que passou a ser empregado em relação à diplomacia do regime militar brasileiro. No mesmo sentido, a ditadura também apoiou, no âmbito da OEA, a tentativa norte-americana de constituir uma Força Interamericana de Defesa, que seria responsável por futuras intervenções em países da região ameaçados pela subversão interna ou externa. Por oposição dos demais países, tal proposta não foi aprovada. O Brasil voltava a ter uma política, ainda que discreta, de projeção de poder (tanto política como econômico) e descaso com as demais nações latino-americanas, sempre se alinhando com a Casa Branca." (Vizentini, 2008: 42).

${ }_{125}$ José Honório identifica em Rio Branco, mesmo que limitada, uma tentativa de maior equilíbrio da Política Externa Brasileira. A respeito ver: Rodrigues (1995).

${ }^{126}$ Segundo o professor Rafael B. Marquese, o "trafico negreiro transatlântico", foi: “... o motor da expansão da agricultura escravista de exportação na primeira metade do século XIX. No Brasil, ele se tornou igualmente a questão externa mais crítica para o Império recém-fundado. As pressões inglesas pelo término do tráfico, agudas entre 1820-1850, colocaram seriamente em risco a soberania nacional e a segurança externa do Império. O tráfico de escravos transatlântico teve também, como um de seus desdobramentos, o aguçamento de certas questões internas no Brasil: a unidade ou desintegração do Império passava pela questão do tráfico negreiro e a pressão que os ingleses impunham para o seu fim." (Marquese, 2004: 266).
} 
segunda metade do século XIX, porém, nos limites de sua condição subalterna, existiram formas de oposição, e não somente de passividade.

(...) Nos primeiros 28 anos de nossa existência independente, foi a GrãBretanha o centro de nossa vida internacional, dominando-nos, obtendo concessões e privilégios hoje inconcebíveis, mas foi dela também que dependeram em parte nossa Independência e nossa soberania, embora ofendida. Se nossa primeira aspiração - ganhar a Independência - contou com a indispensável colaboração britânica, a segunda - defender os interesses da classe agrícola dominante - teve a sua maior forte oposição. (...) Creio que nas manobras diplomáticas com a Grã-Bretanha esteve o eixo, o dogma, se há dogma, a diretriz fundamental de nossa política exterior até 1865 , pelo menos. (Rodrigues, 1966: 16).

O Brasil mantinha o tráfico visando à defesa dos seus interesses da agricultura e principalmente da lavoura açucareira principalmente, que dependia de mão de obra escrava. Por causa disso, não foi atendida a exigência inglesa de abolição do tráfico da África, segundo interesse primordial dos nossos objetivos diplomáticos. Ganhou, assim, maiores proporções a condição conflituosa que Brasil e Grã-Bretanha encontravam-se durante a primeira metade do século XIX. Segundo José Honório, “... foram a Grã-Bretanha e a África os objetivos primordiais de nossa política externa e a evidência disso se nota já ao reconhecimento de nossa Independência quando nos obrigamos a não aceitar a adesão das possessões portuguesas na África." (Rodrigues, 1966: 18).

Na defesa de uma política que permitisse uma maior autonomia ao Brasil no cenário internacional, José Honório identificava na resistência do país, em aceitar de forma unilateral as determinações da Inglaterra que exigia a eliminação a escravidão no território nacional, uma proposta de romper, ou pelo menos, afrontar o imperialismo inglês da primeira metade do século XIX. O intelectual carioca explicava que:

A pressão inglesa desde 1825, expressa na política de Castlereagh e de Canning, exigia a abolição do tráfico, impossível de se fazer naquela época. A abolição do tráfico significava a ruína de nossa economia agrícola, prejudicava nosso comércio e navegação, diminuía as rendas do Estado e rejeitava um recrutamento de gente que não estávamos em condições de repudiar. (Rodrigues, 1966: 15). 
As afirmações que identificam uma postura de subserviência da política externa brasileira, frente às exigências do imperialismo (primeiro o inglês e depois o norte americano) com a disputa por maior hegemonia na região da Bacia do Prata, não são exclusivos ao longo do século XIX. Para exemplificar a condição de defesa do território, base da condição de enfrentamento do Brasil na região, podemos recorrer ao caso da ascensão de Rosas, que queria recriar o Vice-Reinado do Prata, fragmentado na luta pela Independência.

Quanto a América em geral e a Latina em particular, somente por volta de 1831 começou o Brasil a pensar em relações com os vizinhos, quando "mais franco e livre em suas deliberações e arbítrio", afirma Carneiro de Campos, Ministro do Exterior, referindo-se, naturalmente, à Abdicação. Ele pretendia cortar algumas missões européias para estabelecer outras na América. (...) A partir de 1843 complicaram-se os nossos negócios com as Repúblicas do Prata (Argentina e Uruguai) mas, somente por volta de 1848-1850 é que eles passaram a avultar nos objetivos internacionais do Brasil. Agora nossa política começa a se regionalizar ou continentalizar; buscávamos garantir o status quo territorial e seu equilíbrio, baseados no princípio da manutenção do Uruguai e da independência do Paraguai, a fim de evitar o sonho de Rosas de recriar o ViceReinado do Prata, que se fragmentara com a luta pela Independência. A conservação do statu quo significava manter a divisão tri ou quadripartida dos três Estados independentes, evitando que se reunissem num novo agrupamento. (Rodrigues, 1966: 21).

Para o Brasil seria de interesse fazer valer sua supremacia na região instituindo um controle territorial que fosse de acordo com a histórica ocupação das terras. Com relação à definição territorial e as disputas de espaço na América Latina, o intelectual carioca afirma que:

A política dos limites, ouro propósito da nossa diplomacia no continente, consistia em defender as extensas fronteiras que foram conquistadas e possuídas por luso-brasileiros, caboclos e mamelucos, em fixá-las nos tratados e em demarcá-las no terreno. Mais 16 mil km foram fixados sem o derrame de uma só gota de sangue, sem um tiro, apenas com a prova da história, dos mapas e do direito de posse uti possidetis. Então, como nas relações com a Europa, domina a ideologia pacifista, o recurso a arbitragem, precisamente porque a oposição jurídica era a que convinha a posição vital, à aspiração e defesa dos nossos 
objetivos nacionais. Sem entrar em litígio, almejamos manter o espaço que nossos antepassados desbravaram. (Rodrigues, 1966: 26).

Essa afirmação de José Honório Rodrigues remete ao interesse primordial do Brasil na região, ou seja, a grande aspiração nacional a manutenção da unidade territorial e ampliação dos seus limites. Segundo a avaliação honoriana, nessa busca por defender as aspirações legítimas fundamentais para o povo brasileiro, corríamos risco de perder espaço no cenário político da América Latina, portanto o país não poderia aceitar passivamente qualquer tipo de imposição.

O pensamento nacionalista-liberal de José Honório manifesta a tentativa de ruptura da condição "servil e passiva" (Rodrigues, 1966), frente ao quadro da estrutura capitalista do século XIX. O mundo passando pela consolidação do capitalismo, enfrentando a disputa entre os dois principais expoentes do imperialismo, estágio característico do capital na segunda metade do século XIX, capitaneado pelas principais potencias de então, Estados Unidos e Inglaterra, levou a adoção de políticas econômicas que tinham como meta estender seus domínios para a América Latina. Ao nosso entendimento essa especificidade da "Era do Capital"127 não pauta as assertivas de Honório a respeito do tema, sua interpretação esta ancorada na ideia de "força emergente", na possibilidade do Brasil, superando os obstáculos internos - elite dirigente que não se concilia com o povo -, o país estaria apto a tornar-se uma potência.

Nesse sentido nos parece um limite interpretativo de José Honório Rodrigues, pois suas conclusões esboçam a ideia de uma liderança redentora que poderia, conciliando-se com o povo e colocando em prática medidas de integração da sociedade civil, superar a condição de colônia, ou mesmo, de economia dependente.

\section{4 - A aproximação do Brasil com a China comunista e os países africanos: interesses de uma possível potência.}

Ainda na tentativa de instituir um país dinâmico e autônomo, o intelectual carioca aponta a necessidade do Brasil em manter relações comercias com os

\footnotetext{
127 A designação "Era do Capital" foi elaborada pelo historiador inglês Eric J. Hobsbawm para explicar: “A partir da segunda metade do século XIX, uma nova palavra entrou no vocabulário econômico e político do mundo "capitalismo". Portanto parece apropriado chamar o presente volume A era do capital, um título que também faz lembrar a todos nós que a mais importante obra do mais formidável crítico do capitalismo, O capital, de Karl Marx (1867), foi publicada nessa época.” (Hobsbawm, 2001: 19).
} 
países pertencentes ao bloco comunista, entre esses a China, e também com os países africanos, caso especifico Angola, é a tentativa do Brasil de consolidar sua autonomia e lançar-se na tentativa de criar um bloco de países que pudessem manter um comércio e, como resultado, beneficiar o papel brasileiro no comércio internacional.

As relações entre o Brasil e o Oriente, mais especificamente com a China, foram sempre descontínuas e irregulares. O comércio entre Portugal e o Oriente, especialmente com suas colônias na Índia e em Macau, não excluía o Brasil, que não era estação de pouso para os navios da carreira da Índia. A história do Império lusitano não se compõe de compartimentos estanques e pode-se dizer que pelo menos até os meados do século XVII houve uma propriedade comercial portuguesa nos mares da China. A proibição que a dinastia Ming impusera ao comércio e intercâmbio dos chineses com os japoneses permitiu que os portugueses de Macau estabelecessem praticamente um monopólio do comércio e transporte triangular Cantão-Macau-Nagasaki, suplementado pela linha Macau-Manila e baseada na troca de seda e de ouro chineses pela prata e o cobre japoneses.

A liquidação do Império português no Oriente pelos holandeses, já por volta dos meados do século XVII (Jacarta foi perdida pelos portugueses em 1619) não impediu que o comércio chinês-português continuasse através de Macau. $\mathrm{O}$ monopólio comercial português na China, através de Macau permitiu que se organizasse uma troca de produtos chineses com artigos portugueses e brasileiros e, mais tarde, uma corrente autônoma integrada no comércio triangular afro-asiático-brasileiro. Quando esse comércio se consolidou, pelos meados do século XVIII, o Império português na Ásia estava reduzido, na Índia, nos minúsculos territórios isolados de Goa, Damão e DIU, depois da derrota imposta pelo Marathas em 1737-1740, à Ilha de Macau, na Costa da China e à parte da Ilha de Timor, nas Índias Orientais. (Rodrigues, 1966: 109).

Dessa forma José Honório Rodrigues descreve o início da relação comercial que, mesmo na condição de colônia, já mantínhamos com a China. O histórico traçado se reproduz e amplia, com todos os dados peculiares que a trajetória política do país passa desde o século XVII. Trata-se, assim, de uma relação comercial que foi efetiva ao longo das relações exteriores do Brasil. José Honório relata que não era surpresa que os primeiros viajantes chegados ao Rio de Janeiro logo após a instalação da Corte reconhecessem traços asiáticos ou simplesmente orientais na paisagem da cidade ou nos costumes da gente. 
Com a chegada da família real em 1808, o Rio de Janeiro ganha um aspecto europeu, tendo a instalação da corte, representado uma "reeuropeização da Capital do Brasil". O episódio da abertura dos portos e a expansão comercial de predominância anglo-francesa acentuaram esta tendência europeizante e fizeram declinar o comércio asiático. Nada evitou a decadência das relações comerciais sinobrasileiras, nem sequer a proteção que D. João decretara em 13 de maio de 1810, "ao isentar de diretos de entrada nas alfândegas do Brasil as mercadorias da China, de propriedade, e em navios portugueses exportadas diretamente de Macau para este Estado do Brasil.” (Rodrigues, 1966: 112)

A verdade é que a partir de 1810 o processo de reeuropeização ${ }^{128}$ tornase amplamente acentuado dificultando os laços comerciais e culturais com qualquer outra nação. Estávamos presos à lógica instituída com a chegada da família real e aos acordos que Portugal assinou com a Inglaterra. José Honório Rodrigues segue em sua descrição de como foi importante e, mais ainda, constante a relação comercial com a China. Outro aspecto a ser destacado pelo historiador carioca foi à forma de chegada ao Brasil de trabalhadores chineses intensificando o contato entre os dois povos.

No Brasil também se discutiu muito a oportunidade da vinda dos cules chineses - trabalhadores provenientes de Macau -, desde que a libertação dos escravos fosse criar a carestia de mão-de-obra. O principal defensor da imigração dos cules foi José Pedro Xavier Pinheiro. Sua tese era lógica e objetiva e assim de resumia: a extinção do tráfico de escravos exigia medidas destinadas a preencher a falta que na oferta do trabalho rural se faria sentir; a agricultura via aproximar-se a hora fatal e inevitável da grande revolução econômica que a emancipação da escravatura promoveria; a experiência estrangeira mostrava que o Brasil devia volver suas aspirações para o suprimento dos trabalhadores na Ásia Oriental, onde havia inesgotáveis mananciais. Era no reservatório copioso da Índia e China, especialmente os cules chineses, que vários países haviam buscado os trabalhadores agrícolas. (Rodrigues, 1966: 119).

No cenário descrito acima, a relação entre as duas culturas cada vez mais se particulariza: não mais apenas pela relação tipicamente comercial, como na condição de colônia fora mantida com a região de controle político português de Macau, mas

\footnotetext{
${ }^{128}$ A respeito da reeuropeização afirma Gilberto Freyre: “A reeuropeização do Brasil começou fazendo empalidecer em nossa vida o elemento asiático, o africano, ou o indígena, cujo vistoso de cor se tornara evidente na paisagem, no trajo e nos usos dos homens." (Freyre, 2004: 432)
} 
agora também pela ampliação de laços de caráter cultural, com a chegada dos trabalhadores daquela região, denominados de cules. Essa aproximação foi decisiva para que a presença dos chineses contribuísse para a formação da sociedade brasileira. Cabe destacar que as relações políticas com a China foram restabelecidas durante o período republicano, mesmo com a situação desfavorável aos chineses no cenário internacional, que desde a primeira metade do século $\mathrm{XIX}^{129}$, esteve envolvida em um conflito com França e Inglaterra.

Já no período republicano, José Honório Rodrigues procurou demonstrar que houve por parte da diplomacia brasileira tentativas de retomar uma prática de acordos e aproximação efetiva com a China, principalmente com a chegada de chineses como mão de obra no Brasil. Todavia, ao longo do primeiro quartel do século $\mathrm{XX}$, a China foi perdendo seu espaço no Oriente pela forma como o Japão foi consolidando-

${ }^{129}$ O sociólogo A. Roux nos oferece um interessante painel histórico-social de desenvolvimento do Estado Chinês, destacando principalmente o momento de ação do imperialismo inglês: "Entre 1839 e 1860, a Inglaterra, inicialmente sozinha (primeira guerra do ópio, 1839-1842), depois aliada à França (segunda guerra do ópio, 1858-1860) impõe pela força das armas à China dos Ching (Manchus) a abertura ao comércio internacional. Em 1839, o Império do Meio estava fechado, com exceção de entrepostos exíguos em Cantão, nos quais negociantes estrangeiros, principalmente britânicos, mantinham relações comerciais apenas com a corporação dos comerciantes chineses. (...) Abalada pela revolução industrial, à Inglaterra batia na porta inutilmente. Comprava grandes quantidades de chá (12.700 toneladas em 1720, 360 mil toneladas em 1830) que, na época, só a China produzia. Mas, no início da década de 1820, a balança comercial com o Ocidente tinha-se invertido em detrimento da China, em razão da importação maciça de ópio, introduzido fraudulentamente por comerciantes ingleses e norte-americanos . A Inglaterra liberal de lorde Henry Palmerston decidira apelar para qualquer pretexto, para abrir o país, sem restrições, não somente para a droga, mas também para os tecidos de algodão de Lancashire e para as quinquilharias de Birmingham. A destruição das caixas de ópio, pertencentes a negociantes ingleses residentes em Cantão, pelo vice-rei Lin Zexu, em junho de 1839, foi o pretexto esperado para que se iniciassem as hostilidades. (...) Em 1860, quando foi assinado o tratado de Pequim, que daria prosseguimento a uma longa lista de tratados qualificados pelos chineses de "desiguais", onze portos, dentre os quais Cantão, Xangai, Hankou e Tianjin, foram abertos ao comércio; os direitos alfandegários foram limitados a um máximo de $5 \%$. Os ocidentais tinham o direito de circular no interior do país e aí adquirir propriedades rurais sem pagar mais de $2,5 \%$ de impostos. Nesses portos abertos, chamados de "portos de tratado", os estrangeiros, beneficiando-se da extraterritorialidade, começaram a desenvolver "concessões", como em Xangai. Dessa forma, alguns bairros das cidades escapam, de fato, se não de direito, à autoridade chinesa. Proibido por diversas vezes desde 1796, o comércio do ópio pôde, a partir de então, desenvolver-se sem obstáculos: passou de 30 mil caixas de droga, em 1838 (de contrabando), para 68 mil caixas em 1850, e 96 mil em 1873. (...) Todas as potências estrangeiras passaram a dispor, a partir de então, de missões diplomáticas permanentes em Pequim. A Inglaterra fez da pequena ilha de Hong Kong uma colônia da Coroa, enquanto a Rússia, por atuação diplomática, adquiriu mais de um milhão de quilômetros quadrados, da margem Norte do rio Amur até a margem oriental do Ussuri. (...) Além disso, o país foi sacudido por diversos movimentos de revolta, por vezes separatistas (populações muçulmanas turcas); outro, como o movimento Taiping, conseguiu até fundar uma dinastia rival que reinou localmente durante dez anos. Eram rebeliões muitas vezes incentivadas por sociedades secretas, como a Tríade, enriquecidas pelo contrabando de ópio. Nesse contexto, as autoridades chinesas tinham três preocupações: uma interna: restabelecer a ordem; a segunda, geopolítica, já que os perigos do ataque dos "bárbaros" (ou seja, os ocidentais) no litoral Sul foram subestimados, enquanto o levante do grande Oeste, apoiado pelo Império dos Czares, bem próximo, foi considerado um perigo maior. A terceira preocupação era econômica: a hemorragia de dinheiro provocada pelo contrabando de ópio. Além do empobrecimento do país, disso resultava uma grave tensão social: as classes populares eram pagas com moedas de cobre que se depreciavam diante da prata, que servia de base para o cálculo dos impostos." (Roux, 2004). 
se, visto que este se apresentava como um país muito mais atraente e próximo do ponto de vista de sua organização e seu potencial de desenvolvimento capitalista para os interesses do mundo Ocidental. A situação de opressão a que os chineses foram lançados a partir de então, perdendo espaço e condição de seu desenvolvimento e contato com o Ocidente para os japoneses, teve como consequência imediata uma situação de desequilíbrio econômico, que levou a enorme população chinesa a uma debilidade social e econômica expressiva. (Cervo, 1995).

Não há relação mais sinistra que a história da agressão ocidental à China, “... civilização milenar, um Império de mais de cinco mil anos, quando violentado pela ambição de lucro do Império britânico e dos Estados Unidos. Sua permanência histórica, sua unidade territorial e imensidade territorial não impediram a agressão ocidental." (Rodrigues, 1966: 130).

As condições em que o presidente Jânio Quadros assume a presidência levam a um posicionamento por parte do governo. Em 22 de fevereiro de 1961, menos de um mês depois de sua posse, houve uma nota presidencial que dava "instruções ao Ministério das Relações Exteriores para que, na próxima reunião das Nações Unidas o Brasil vote a favor da inclusão na agenda de trabalho a proposta da relativa à representação da China na ONU.” (Rodrigues, 1966: 147).

A clara intenção de Jânio Quadros era que sua política exterior estivesse independente e não submissa à liderança norte-americana, por mais que essa medida fosse identificada como mera estratégia para seus interesses e não como uma forma de preocupação do ponto unicamente diplomático. (Rodrigues, 1966). O conturbado governo de Jânio não permitiu que a aproximação, quanto às discussões na ONU, fossem plenamente equacionadas, porém cabe destacar que houve o envio de uma missão comercial capitaneada pelo então vice-presidente João Goulart.

A Missão Comercial enviada à China em 1961, chefiada pelo então vicepresidente João Goulart e integrada por políticos, diplomatas e elementos ligados aos meios econômicos. Foram visitadas regiões importantes e celebrados acordos comerciais com autoridades chinesas do primeiro escalão. O Brasil exportaria café, cacau e derivados, algodão, couro, lã, juta, fumo, carnes, pimenta, óleos vegetais, madeira, bens industriais de consumo etc. e receberia da China máquinas-ferramentas, perfuratrizes, carvão, chumbo, zinco, aço, matérias-primas farmacêuticas, bens industriais de consumo, artesanato etc. $\mathrm{O}$ presidente retornou antecipadamente devido à crise da renúncia, mas a missão 
prosseguiu até a conclusão dos trabalhos. (...) O perfil das relações comerciais do Brasil com os países socialistas era, o mesmo que com os países capitalistas industriais, ou seja, matérias-primas e artigos alimentares por bens industriais de capital. Com respeito à China, mantinha-se a mesma pauta, essencialmente, mas aproximava-se em certos aspectos do comércio com o Terceiro Mundo. O que diferia das relações com o Primeiro Mundo era a modalidade desse intercâmbio, mais favorável ao Brasil, como foi visto em capítulos anteriores. Além disso, o campo socialista podia fornecer trigo, petróleo e minerais estratégicos, além de empréstimos facilitados. (Vizentini, 1995: 215).

Não aceitar um posicionamento como mero "testa-de-ferro dos desígnios de Washington" ${ }^{130}$. A condição posta no cenário político internacional durante os anos de 1960 foram determinantes para a postura do Brasil em ter alguma possibilidade de efetivar-se. Alicerçada no nacionalismo típico das investidas no campo do conhecimento que marcaram sua produção, José Honório Rodrigues defende a autodeterminação e a coexistência pacífica que se tornaram os pilares da diplomacia assumida naquele contexto. Pela autodeterminação, cada país tinha o direito a estabelecer suas próprias formas de organização política, econômica e social, independente das ações do mundo bipolarizado, principalmente devido aos "gastos com os arsenais atômicos que deveriam ser reorientados para combate à miséria dos subdesenvolvidos." (Mello, 1998: 50).

As relações comerciais com a China têm se ampliado na base da deterioração do comércio latino-americano com seus mercados tradicionais, mas, a abertura de relações políticas encontra incrível oposição. A diferença fundamental entre o tratamento político na América Latina entre a União Soviética e a China talvez esteja pautada pela divergência que as separa sobre o método da revolução comunista. Problemas sociais e econômicos profundos causam os grandes descontentamentos e a agitação popular na América Latina: suas lideranças insistem em retardar a solução dos problemas, defendendo a condição sócio-política atual. Tal particularidade permite que

\footnotetext{
${ }^{130}$ Segundo o embaixador Adolpho B. de Menezes: "Posto já haver Washington constatado que uma política de "testas-de-ferro" pró-ocidentais, mantida à custa de dólares e de armas, não será suficiente para repressar a expansão sino-soviética na Ásia, que nos parece que será mais vantajosa para os Estados Unidos patrocinarem eles próprios, a socialização desses países asiáticos, de grande densidade demográfica e baixíssimos níveis de vida, do que se arriscarem a vê-los socializados por meios totalitários de inspiração chinesa ou russa. Em regiões tais como a Indochina, a Coréia, ou Formosa, os norteamericanos terão de desistir de procurar, a um só tempo, repressar o crescente prestígio da China comunista, e continuar expandindo suas transações econômicas em bases capitalistas sob a proteção de pseudo-regimes democráticos." (Menezes, 1961: 129).
} 
exista espaço para o surgimento de "propaganda comunista", apesar das restrições típicas do cenário da Guerra Fria em que os partidos comunistas estavam proibidos na América Latina. O intelectual carioca posiciona-se nesse sentido:

Qualquer que seja a base ideológica que move a movimento comunista - seja soviética ou chinesa - o fato é que seu caminho na América Latina encontra sérias resistências. Além disso, na tradição européia, a força do comunismo provém de sindicatos urbanos, enquanto na Ásia provém dos elementos rurais e como os países latino-americanos são agrícolas, a tradição asiática tende a ganhar vigor. Isso talvez explique o fato de que a China não possui representação diplomática na América Latina, à exceção de Cuba. (Rodrigues, 1966: 153).

Dessa forma a conduta de uma política externa independente que fosse ampla e sem nenhum tipo de entrave do ponto de vista ideológico, explica, em certo sentido, a relação com a China. (Bueno, 1992: 286). Com a discussão política que explicava a relação política, a argumentação de nossa diplomacia pautava-se na tríade: desenvolvimento, descolonização e desarmamento - o que gerou acalorados debates no Brasil, aguçados ainda mais quando o presidente João Goulart colocou a política externa independente entre as reformas de base de seu governo. Apesar da advertência de figuras como o chanceler San Tiago Dantas ${ }^{131}$, para quem a independência diplomática significaria ampliar a margem de manobra para o Brasil barganhar no plano internacional sem comprometer os vínculos com o Ocidente, essa orientação foi confundida com neutralismo.

Com resultado, já em 1962, a Política Externa Independente do Governo Goulart viu-se repudiada pelas correntes mais tradicionais para as quais as teses da CEPAL equivaliam à ponta de lança do comunismo na América Latina. A abstenção brasileira em face da expulsão de Cuba formalizada na Reunião de Consulta da OEA, em janeiro de 1962, em Punta Del Este foi duramente atacada pelas correntes hostis ao nacional-populismo do modelo trabalhista herdado do antigo grupo da Itatiaia. Quatro ministros de Relações Exteriores

\footnotetext{
${ }^{131}$ A política externa defendida por San Tiago Dantas, durante seu período como ministro das Relações Exteriores de João Goulart, pode ser percebida no plano de governo adotado na área: "Podemos dizer a posição internacional de nosso país, de que depende a nossa orientação em face das questões concretas que se nos deparam, tem evoluído constantemente para uma atitude de independência frente a blocos políticos- militares, que não pode ser confundida com outras atitudes comumente designadas como neutralismo, ou terceira posição, e que não nos desvincula dos princípios democrático e cristão, nos quais foi moldada nossa formação política.” (Dantas, 2006: 121).
} 
subscreveram carta contrária à diretriz traçada por San Tiago Dantas. (...) Quando, em 1964, o governo Goulart perdeu sua base de sustentação política e militar, a Política Externa Independente entrou em pane. Isso apesar do equilíbrio do chanceler Araújo Castro que se recusou a mobilizar o Itamaraty para o Comício das Reformas, a 13 de março de 1964. (Mello, 1998: 53).

A política externa defendida por José Honório Rodrigues, não estava restrita a relações com o mundo ocidental, mas sim com o mundo todo. Preocupavam-se os adversários dessa política externa, não com a busca de solução que conduzisse à emancipação econômica, mas sim com a prioridade ao sistema de defesa ocidental ligado aos Estados Unidos e com as possíveis vantagens que os empréstimos comerciais traziam a setores reduzidos da Nação.

$\mathrm{O}$ autor de Interesse nacional e política externa, defendia a política própria e independente que pudesse atender aos interesses nacionais, ajudando no desenvolvimento econômico dentro de um contexto internacional. Dessa forma, podiase então identificá-la com os objetivos nacionais. A luta pelo desenvolvimento era primordial e, para tanto, era necessário ampliar os laços com os países do continente africano entre outros. Visando atingir tal intento, José Honório Rodrigues escreve artigos, que foram reunidos e publicados em uma primeira edição de 1962, voltada para as relações entre o Brasil e o continente africano, que ocorriam de forma ininterrupta desde o século XVI, ainda sob os desígnios do sistema escravista. Estava indicada a necessidade de superar essa mácula histórica e travar uma política comercial que favorecesse o desenvolvimento de ambos os territórios e auxiliasse na condição de autonomia das Nações.

Com a implementação da política externa independente durante a gestão Jânio Quadros, o Brasil passava a dar importância decisiva à relação com o continente africano e principalmente com os países de colonização portuguesa. O presidente colocara em prática suas promessas de campanha no que diz respeito à política exterior, o que levou à abertura de várias frentes simultaneamente, não obstante o curto período de sua gestão. Como resultado concreto, determinou que se fizesse um reexame da política brasileira para a África. Na ONU, o Brasil prometia adotar linha própria de apoio ao anticolonialismo e afastamento da delegação portuguesa nesse aspecto.

Outro ponto importante é que a política exterior adotada previa empréstimos à África, o que pode ser observado nos acordos culturais, em um programa 
de bolsas para estudantes e na criação de um sistema de consultas firmado com a Organização Interafricana de Café com vistas à defesa dos preços desse produto no mercado internacional. Uma linha de navegação entre o Brasil e a Indonésia, com escalas na África, deveria aumentar a aproximação. Destaca-se ainda a criação das novas embaixadas junto aos governos de Gana, Nigéria e Senegal, além da abertura de consulados. (Bueno, 1992: 288).

Adotava-se um posicionamento a favor da ruptura com os entraves da colonização portuguesa e com a ação da política lusitana que, nesse contexto, era intitulada salazarismo. O Brasil adotara tímidas posições em relação à possibilidade de discutir livremente e criar estratégias de defesa ampla para que houvesse a superação do nefasto sistema colonialista.

Com o interesse universal pela África, a política internacional do Brasil tem sido menos que tímida e foi até o Governo do senhor Jânio Quadros, aliada submissa dos Poderes Coloniais e Administradores. Na época do presidente Juscelino Kubitschek, a Operação Pan-Americana obscureceu o mais importante fenômeno do processo histórico mundial entre 1958-1960 - a liberdade africana. Se não era um diversionismo, porque representava parte dos interesses nacionais, serviu para ocultar a nossa indefensável marcha, lado a lado, com os poderes coloniais. Votávamos sempre com as potências coloniais das Nações Unidas, cedíamos a todas as pressões portuguesas, a do Governo oligárquico de Salazar ou a da colônia e, vez ou outra, disfarçávamos nosso alinhamento colonial com as abstenções. Não tínhamos uma palavra de simpatia pela liberdade africana, não avaliávamos os perigos que para a segurança nacional poderia representar uma África Ocidental inamistosa, não protestávamos contra organizações como a O.T.A.N. que se tem servido do Atlântico para defesa de interesses coloniais e nunca consultou as aspirações dos povos das duas margens sul. Nada se fazia. A política das Nações Unidas ainda seguia as instruções que permitiram aquele inesquecível pronunciamento de um secretário em 1953, nas Nações Unidas, colocando-nos a serviço do colonialismo português. Era comum o respeito, a submissão a todos os Poderes Coloniais, a crítica, a censura, o pouco caso pelas posições afro-asiáticas que, dia a dia, se fortificavam nas Nações Unidas. (Rodrigues, 1966: 170).

A adoção de um posicionamento a favor da ruptura da dominação impingida pelos países europeus, principalmente a exercida por Portugal, levou José 
Honório Rodrigues a expor, de forma mais evidente, o quanto a sua posição nacionalista-liberal identificava-se com a política externa independente. Com o término da segunda guerra mundial e o fim dos regimes totalitários, não existia mais espaço para a continuidade da dominação portuguesa no continente africano. A situação na região clamava pela adoção de ações que estivessem minimamente comprometidas com todas as discussões, o que tem impacto sobre a postura adotada pelo Brasil de afastar-se da postura oligárquica de Portugal a partir de 1961. O intelectual carioca, no entanto, fizesse ressalvas ao limite desse afastamento.

Com Jânio Quadros mudara o processo histórico, mudara a nossa posição neste processo e, portanto, deviam mudar os objetivos e os métodos de nossa política exterior. Porque se tratava do primeiro Presidente brasileiro que conhecia o outro mundo, que não visitara, como sempre, apenas a Europa e os Estados Unidos, onde se ouvia sempre a mesma lengalenga sobre o nosso destino à margem do precipício, era possível pensar que sua visão era ampla e universal, como exigia nossa nova condição de Potência Média, um dos países-chave da chamada área livre do mundo. (...) E foi isso que o Presidente Jânio Quadros iniciou. Fez pouco em seus sete meses de gestão, mas reformulou diretrizes e tomou algumas iniciativas básicas, que tanto irritaram os verbocratas, muitos funcionários diplomáticos, muitos políticos ligados a interesses retrógrados que geraram aquele sentimento de vergonha na consciência de certas classes, nascida da instabilidade política provocada pela luta entre as tradições da sociedade arcaica e o Brasil novo. Na verdade, a política exterior sempre refletiu os interesses das classes rurais, da oligarquia dominante e de certos setores afortunados das classes médias superiores. (Rodrigues, 1966: 172).

Dessa forma, o governo assumia a posição de romper com o tradicionalismo que imperava na política externa, já que sua organização era pautada por interesses de setores específicos da sociedade, que em sua grande maioria estavam atados aos Estados Unidos pela necessidade comercial. A mudança de foco apontava um caminho inovador, pois representava o enfrentamento dessa peculiaridade tão típica de nossa elite. No entanto, a dificuldade em posicionar-se, principalmente devido aos rumos que os movimentos anticoloniais tomaram na África ( no caso especifico de Angola e Moçambique), levaram a uma impasse: aceitar ou não tais levantes revolucionários socialistas, principalmente com a crescente aproximação da União 
Soviética e da África. ${ }^{132}$ Nessa conjuntura, era necessário que o posicionamento do Brasil fosse muito bem pensado e organizado para que não levantasse nenhum tipo de insatisfação interna e externa. Um bom exemplo dessa situação pode ser visto na questão de Angola.

Em Angola, com uma forte ação dos movimentos de libertação capitaneados por Agostinho Neto ${ }^{133}$, o processo de emancipação iniciado em 1961 foi concretizado em 1974 com a Revolução dos Cravos ${ }^{134}$. Essa manifestação de caráter revolucionário colocou a necessidade de discussões na ONU, em que o Brasil teve que posicionar-se, o que ficou a cargo do ministro Afonso Arinos de Melo Franco. A postura assumida indicava os históricos laços culturais que nos aproximavam de Portugal e o anticolonialismo. Manifestou-se ainda o desejo por uma solução rápida, que compatibilizasse os interesses de ambos os lados - portugueses e angolanos - e que preservasse, o quanto possível, os elementos culturais e humanos que caracterizavam a presença portuguesa na África. Ainda houve por parte da diplomacia brasileira a indicação de que aguardávamos a aceitação do princípio de autodeterminação por parte de Portugal, exortando-o a assumir a direção do movimento pela liberdade de Angola e pela sua transformação em um país independente, tão amigo de Portugal quanto do

\footnotetext{
${ }^{132}$ A respeito do cenário histórico-político, o historiador inglês Eric J. Hobsbawm, explica que: "Durante várias décadas, a URSS adotou uma visão essencialmente pragmática de sua relação com os movimentos revolucionários, radicais e de libertação do Terceiro Mundo, pois nem pretendia e nem esperava aumentar a região sob governo comunista além da extensão da ocupação soviética no Ocidente, ou da intervenção chinesa no Oriente. Isso não mudou nem no período de Kruschev (1956-1964), quando várias revoluções autóctones, em que os comunistas não tomaram parte, chegaram ao poder com energia própria, notadamente em Cuba (1959) e Argélia (1962). A descolonização africana também levou ao poder líderes que não pediam nada melhor que o título de antiimperialistas, socialistas e amigos da União Soviética, sobretudo quando esta levava ajuda técnica e outras não maculadas pelo velho colonialismo. Moscou simpatizava com os novos regimes e ajudou-os, embora logo abandonando o excesso de otimismo sobre os novos Estados africanos. No ex-Congo Belga, deu apoio armado ao lado lumunbista contra os clientes ou títeres dos EUA e dos belgas na guerra civil que se seguiu à precipitada concessão de independência à vasta colônia." (Hobsbawm, 1995: 423).

${ }^{133} \mathrm{O}$ professor Carlos Serrano traz uma painel do contexto revolucionário em Angola, afirmando que: "Com a ação do Movimento Popular de Libertação de Angola (FNLA) e a União para a Libertação Total de Angola (UNITA). Tanto a FNLA E UNITA defendiam programas pró-ocidentais, mantendo certo enraizamento étnico. Diante da crescente mobilização dos africanos, as forças de ocupação simplesmente não foram páreo para os movimentos de libertação. Motivados ideologicamente, bem treinados, utilizando armamento adequado e excelentes conhecedores da geografia local, em poucos anos lograram libertar vastos territórios e gerar insegurança permanente nas autoridades locais. Como resultado, no início dos anos de 1970, após mais de uma década de lutas contra a guerrilha africana, a população e a economia de Portugal davam crescentes sinais de esgotamento, fazendo crescer a oposição ao regime." (Serrano, 2007: 262).

${ }^{134}$ Segundo o professor José Paulo Netto: "Um dos resultados relevantes com a derrubada do fascismo português em 25 de abril de 1974 e a deposição de Marcelo Caetano foi o coroamento do processo de descolonização cujo mérito maior cabe aos movimentos de libertação articulados pelos povos submetidos ao jugo colonial." (Netto, 1986: 57).
} 
Brasil. A representação brasileira reiterava os termos da amizade portuguesa e, ao mesmo tempo, apoiava Angola na busca da autodeterminação.

A posição de San Tiago Dantas a respeito da empreitada expunha uma visão moderada e conciliadora. A meta deveria ser de que o Brasil buscasse vislumbrar a determinação dos povos, mesmo que num contexto revolucionário e de total instabilidade. A forte amizade com Portugal impedia uma análise mais crítica da situação, afirmava o chanceler que:

Cumpre notar que no caso de Angola jamais o Brasil olvidou os laços de solidariedade histórica que o unem a Portugal. Pelo contrário, o que tememos, ainda hoje, é que uma posição política demasiado rígida comprometa o papel que a cultura portuguesa pode representar na África a longo prazo, e tornar difícil, senão impossível, a transformação dos vínculos atuais em outros de caráter comunitário, cuja preservação seria útil a todos os povos de língua portuguesa e manteria Angola no quadro cultural e político do Ocidente. (Dantas, 2006: 13).

O que estava em jogo era a tentativa de San Tiago Dantas em protelar a questão. Apesar da ênfase que a Política Externa Independente emprestava ao anticolonialismo, a tradicional amizade com Portugal inibia a chancelaria brasileira na tomada de uma posição mais contundente na questão angolana. Embora a política externa brasileira não tivesse apresentado solução de continuidade após a renúncia de Jânio Quadros, no referente à África, San Tiago Dantas não teria ido além da retórica, embora a reação conservadora vislumbrasse algo mais. A Política Externa Independente teria registrado hesitações e recuos nas relações com Portugal.

O posicionamento do Brasil nessa questão levou José Honório Rodrigues a uma grande decepção. Pois no seu entendimento o país adotou medidas que levaram a um retrocesso histórico.

Uma das questões mais graves, discutidas com exaltação na imprensa, era o caso de Angola e a atitude que o Brasil tomaria nas Nações Unidas. Desde as primeiras declarações anti-colonialistas do Presidente e do Ministro do Exterior, esperava-se a hora em que elas seriam postos à prova. A oportunidade surgiria quando o Itamaraty tivesse de formular as instruções que orientariam nossa Declaração nas Nações Unidas. Mas quando chegou a hora da decisão, começaram as flutuações. Havia um Tratado - o da Comunidade, que determinava, como vimos, a consulta sobre os problemas internacionais de 
manifesto interesse comum. No caso, de manifesto interesse lusitano, e que comprometia nossas relações com os países do continente africano. (...) Em 30 de março de 1961, depois de uma conferência com o Embaixador Manoel Rocheta, o Itamaraty distribuiu nota oficial declarando que, em relação ao caso de Angola, o Presidente entendia que "a orientação do nosso País decorre, de um lado, da firme posição anticolonialista do Governo, e, de outro, dos compromissos internacionais e dos vínculos de natureza especialíssima que unem o Brasil e Portugal"; e que, consequentemente, haviam sido expedidas instruções à nossa delegação nas Nações Unidas, no sentido de se abster da votação sobre a matéria. (Rodrigues, 1964: 380).

José Honório Rodrigues afirmava que a marcha ré se materializava antes mesmo da chegada de Afonso Arinos ${ }^{135}$ a Lisboa "para consultar o governo português" (Rodrigues, 1964). A viagem a Portugal representou uma das maiores fraquezas e contradições da política de Jânio Quadros. De volta "depois de fazer grandes elogios a Salazar" (Rodrigues, 1964: 381), Afonso Arinos declarava que o Brasil se reservava o direito de acompanhar a decisão sobre a situação africana com liberdade, condenava o colonialismo, reafirmava a unidade de ação dos dois governos em outros assuntos que interessassem à sociedade, e apoiava a autodeterminação dos povos capazes de almejar à independência. Não havia maior imbróglio, já que se insinuava que opinar sobre Angola era intervir nos negócios internos de Portugal e supunha-se que Angola não fosse capaz de aspirar à independência. $\mathrm{O}$ recuo estava feito, e apesar das declarações do Ministro de que só o Brasil decidiria a respeito de seu posicionamento, a verdade é que houve uma constrangedora abstenção do país na votação da resolução que criava uma comissão para examinar o caso de Angola. Ficava dessa forma evidente a posição hesitante do Brasil em fato de enorme relevância.

Para um intelectual que procurava militar em causas de cunho política, José Honório Rodrigues considerava que o Brasil havia sofrido uma derrota na possibilidade de se tornar mais autônomo e atuante, em uma questão que poderia

\footnotetext{
${ }^{135}$ Cabe destacar que Afonso Arinos era um defensor da Política Externa Independente e foi Ministro das Relações Exteriores durante o governo Jânio Quadros, num discurso no Senado para falar dos planos de sua pasta ministerial afirmava que: "No campo que nos interessa, o mundo passa por uma divisão ideológica que acaba afetando o campo jurídico, o pensamento político, e acaba sendo de interesse de todos aqueles que prezam pela paz mundial, eu posso garantir aos senhores, esta em jogo, é aquilo que poderíamos chamar de soberania nacional e a organização internacional, o contraste naquilo que a soberania nacional assegura à subsistência e a sobrevivência do direito do Estado e aquilo que a organização internacional, pelo menos no seu significado mais atual, mais profundo, mais moral, reclama como sendo a afirmação dos direitos humanos.” (Franco apud Lattman-Weltman, 2005: 142).
} 
nitidamente expor o posicionamento do Brasil no cenário internacional. Cabe destacar que a situação do país naquele contexto permitia a possível ação pró-independência angolana. O nacionalismo-liberal, defendido pelo intelectual carioca, sofria uma baixa pelo caráter nitidamente ideológico da posição assumida pelo Estado brasileiro. Não abríamos condições para uma ação claramente favorável à liberdade e valorização de interesses amplos da sociedade brasileira, que pleiteava uma maior liberdade na política internacional. A medida adotada nesse episódio colocava em xeque inclusive os argumentos da Política Externa Independente ${ }^{136}$, naquilo que seus artífices argumentavam como um projeto coerente, articulado e sistemático visando a transformar a atuação internacional do Brasil. (Vizentini, 2008: 30).

O papel brasileiro diante da "questão de Angola" tomava rumos que cada vez mais constrangiam o país. Para nos determos nas argumentações de José Honório Rodrigues diante do fato, cabe lembrar que para ele o posicionamento de certas instituições denota o quanto a sociedade brasileira (entendida aqui como setores específicos e aliado a grupos importantes no que diz respeito à influência junto ao poder político) se posiciona a favor da Política Externa Independente. Vejamos, por exemplo, o posicionamento da imprensa diante da postura do país.

Um dos principais órgãos da imprensa de São Paulo - O Estado de São Paulo de 9/6/1961 - comentou, sob o título de "Um estranho Embaixador", que se tratava de "um homem comprometido, cujas opiniões sobre a conjuntura

\footnotetext{
${ }^{136}$ Parece-nos pertinente resgatar aqui a definição a respeito da Política Externa Independente: "O que afinal foi a Política Externa Independente afinal? Ela pode ser considerada uma resposta da diplomacia brasileira às aceleradas transformações internacionais, em particular o surgimento de novos atores e a modificação do caráter de outros, cujas necessidades e cujos anseios os posicionavam fora da política dos centros dominantes. A orientação diplomática da PEI respondia à atitude dos Estados Unidos com relação à América Latina até a Revolução Cubana, percebida como um "descaso" caracterizado pela ausência de investimentos públicos norte-americanos para a área de infra-estrutura e de bens de capital. O "descaso" transformava-se em forte pressão política e econômica quando as nações latino-americanas tomavam qualquer atitude visando modificar, ainda que parcialmente, as relações de dependência, para lograr o desenvolvimento nacional. (...) Igualmente importante foi a adaptação da política exterior brasileira às transformações do sistema internacional em fins dos anos 50 e início dos anos 60, tais como: a recuperação econômica da Europa Ocidental e do Japão; a descolonização da África (que ao tornar-se independente perdia vantagens tarifárias como concorrente brasileira e tornava-se um mercado alternativo de produtos industriais); a consolidação do campo socialista, em especial a emergência da União Soviética à condição de potência mundial; o surgimento do Movimentos dos Países Não-Alinhados, decorrentes da emergência do Terceiro Mundo no cenário mundial e a Revolução Cubana. O novo contexto mundial iria repercutir no Brasil, permitindo ao país transitar de uma diplomacia realmente mundial. Além disso, a Política Externa Independente constitui uma estratégia coincidentemente utilizada para questionar o status quo mundial e negociar uma nova forma de inserção internacional do país ou renegociar o perfil de sua dependência. Existem também as análises que identificam na Política Externa Independente a atenção nas relações entre Brasil e Estados Unidos e seu crescente deterioração, entendendo a postura brasileira como uma forma de reação nacionalista ao hegemonismo norteamericano, além de ser fundamental como instrumento diplomático do interesse nacional, isto é, como elemento de apoio do processo de desenvolvimento industrial brasileiro. (Vizentini, 2008: 28).
} 
portuguesa são suspeitas, refletindo fielmente os pontos de vistas oficiais do próprio Governo luso". Era, assim, mais um serviço que se prestava à ditadura portuguesa e ao colonialismo lusitano e o Embaixador, ao visitar a "Província", não viram o drama ensanguentado, mas voltou satisfeito, pois notara "os muitos indícios de progresso, representados por estradas excelentes e grandes cidades, além de sua bela capital”. Apreciou, também, realizações importantes, tantos públicas como particulares de grande interesse. "Estou em minha Pátria. Esta é a mesma alma, este é o mesmo sangue", acrescentando, para ilustração de historiadores, que o "Brasil, que nós fizemos com portugueses idos de Angola como de todos os quadrantes de Portugal, é ainda hoje, a nação que se honra e orgulha dos princípios de liberdade, autêntica liberdade e igualdade que os portugueses lá souberam implantar". O estranho e parcial representante brasileiro enviado a Angola apresentou um relatório ao Itamaraty, conservado até hoje em seus arquivos fechado ao conhecimento público pela política do sigilo - uma herança colonial portuguesa. (Rodrigues, 1964: 383).

A política externa independente brasileira acabou constituindo um reflexo limpo de toda história que procurava conciliar-se com o povo e atender às mais legítimas aspirações desses. Dominada por uma oligarquia que antes dela se servia (do que servia à Nação) e dirigida por uma elite alienada em sua formação, a política externa teve, como toda nossa história, as horas de criação autônoma e livre, além de dirigentes que souberam defender com firmeza os interesses do país. Os instantes de sucessos não são somente raros. Para o intelectual carioca, as condições postas pela elite dirigente do país concretizam um projeto anti-povo e pouco disposto a melhorar a situação dos setores subalternos. O questionamento imediato que se coloca é de como a política externa poderia ser decisiva na melhoria das condições de vida dos setores subalternos da população brasileira. A explicação de José Honório Rodrigues versa a respeito de um povo, que se encontra escamoteado em suas mais imediatas necessidades, uma massa que sofre com o líder caiado.

A procura incessante é pela possibilidade de atingir a "real soberania popular" o governo brasileiro. Para alcançar a forma de um nacionalismo-liberal, faz-se a nacionalização e os interesses nacionais passam a ser prioritários, para benefício do povo e não de poderosos grupos econômicos. Libertar o governo das minorias alienadas e de seus agregados, os caiados, "que já em 1817 se colocaram ao lado da antiindependência, apenas se inicia." (Rodrigues, 1970: 192). O autor de Brasil $e$ 
África: outro horizonte, explica como a libertação do povo e o atendimento de suas reivindicações depende de um país autônomo no cenário mundial, Honório argumenta que:

Os males da nossa história advêm da oligarquia, das minorias dominadoras que querem evitar a opção pelo progresso, a libertação do povo e da nação de todas as servidões. Ela quer impedir o fim de seus privilégios e o começo imediato da História como nossa realidade e vivem no mundo europeu, ou euro-americano, sob padrões alienígenas; jamais reconhecem. (...) Porque suspiram pela Europa - e amam todos os Poderes maiores - aspiram as nossas minorias a manter o statu quo, evitando a reforma e a sua urgência. (...) Incapazes de distinguir com clareza os interesses nacionais permanentes, buscando nas fórmulas jurídicas as soluções imediatistas e transitórias, persistem em coexistir, no temor e no erro, com o povo. Nossa história, de evolução muito lenta até recentemente, se compõe de pequenos sucessos, fruto mais da paciência, da persistência, do otimismo, do estoicismo do povo, que do jeito ou habilidades da minoria dominante. Ela encontra no compromisso político um jeito de ludibriar o povo, que do jeito ou habilidades da minoria dominante. Esta encontra no compromisso político um meio de ludibriar o povo e de desviar o processo histórico do caminho do progresso e da justiça social. (Rodrigues, 1970: 193).

Isso explica o argumento de José Honório Rodrigues, que procura a defesa da liberdade do povo e acredita que essa possa ser alcançada com medidas que automatizem nosso afastamento em relação aos europeus, iniciada com o Barão do Rio Branco, que conseguiu dosar a aproximação consentida, não aceitando a total dependência. A Política Externa Independente propunha, agora de forma mais incisiva, uma política de afastamento com os norte-americanos, a aproximação com os países socialistas, exemplificado com os laços com a China, além de um posicionamento de aproximação com a África. Com o golpe militar voltávamos na condição de alinhamento automático, sem qualquer poder de barganha, tal postura era inaceitável. O Ministro das Relações Exteriores do General Castelo Branco, expõe a seguinte opinião a respeito da PEI:

Alguns analistas consideram que a política externa independente era influenciada por ideologias que não levavam em conta o interesse do país. $\mathrm{Ou}$ seja: foi danosa aos interesses do Brasil. O que o senhor acha? ponto é certo. Acho que não podemos fazer as coisas irresponsavelmente: temos 
um governo de direita fazendo uma política de esquerda, de maneira que fica confuso. O ministro do Exterior tem que tomar cuidado. E essa política continua até hoje a não dar resultados. Estamos com um problema financeiro de tal magnitude que imagino possível a queda da situação num impasse que pode levar a uma guerra civil. O risco é mais interno do que externo. (Cunha, 2003: 230).

O intelectual carioca vê a vagarosidade de tais mudanças como um exemplo da situação de grande morosidade que existe no país quando diz respeito às possíveis vitórias populares. As legítimas aspirações do Brasil e sua interpretação não devem se inspirar nos interesses dos poucos privilegiados do status quo, que “escamoteiam o processo histórico, nem dos reformistas demagógicos que, sob a pressão dos fatos, barganham concessões." (Rodrigues, 1970: 193).

O nacionalismo-liberal de José Honório mais uma vez sofre um golpe, pois a procura de autonomia no cenário mundial é drasticamente abortada pelo movimento civil militar de 1964. A possibilidade de criação dos mecanismos institucionais que poderiam tornar o Brasil um agente de respeito no contexto das relações internacionais, perde espaço para o histórico processo de "alinhamento com os norte americanos" o que impossibilitava qualquer relação que não seguisse os desígnios de Washington. Além do mais, o campo que favorece a práxis de Honório, as discussões a respeito de política externa, nem sua meticulosa análise do processo político e a tentativa de chamar a atenção com textos contundentes, foram capazes de ampliar o efeito da PEI.

Quando Marx, em suas famosas teses contra Feuerbach expõe a característica da práxis, no sentido de um entendimento da realidade e a procura de elementos que a tornem factível socialmente, a sua realização deve ser pela via revolucionária, com Honório temos a tentativa de criar uma sociabilidade "reformada" que atenda ao povo. O intelectual carioca procurava o entendimento do mundo, para que sua obra - fruto de sua compreensão da realidade - fosse efetiva nas condições concretas da realidade brasileira pós 31 de marco de 1964. O governo militar criou em José Honório Rodrigues a necessidade de intervenção, a consciência social prática para tal era o nacionalismo, esse interpretado através das lentes de um liberalismo democrático que, para sua efetivação, deveria encontrar lideranças que colocassem em 
prática um projeto reformista. No campo das Relações Exteriores, o processo teve início, a Política Externa Independente sinalizava nesse sentido, o desfecho foi trágico.

\section{IV - José Honório Rodrigues e o pensamento social brasileiro}

Neste capítulo pretendemos trazer à tona a interpretação de José Honório Rodrigues a respeito da obra de Capistrano de Abreu e Oliveira Vianna. Cabe destacar que os autores em questão são responsáveis por contribuições de fundamental importância, pois fazem parte de uma "rica tradição de pensamento social e político no Brasil” (Brandão: 2007: 22), servindo, assim, de mote a um número razoável de pesquisas $^{137}$. Ambos os autores analisados expressam uma preocupação a respeito da formação e dos dilemas do povo brasileiro, além de apresentar um conjunto sólido de argumentações vinculadas ao âmbito da questão nacional, formação do Estado, elite agrária etc.

Entendemos que o estudo realizado por José Honório Rodrigues a respeito de pensadores como Capistrano de Abreu e Oliveira Vianna ressalta aspectos centrais de seu instrumental de análise, bem como de sua preocupação no campo ideológico. Tais pensadores oferecem, ao autor de Conciliação e reforma no Brasil, a possibilidade de discorrer a respeito do pensamento social e político para o entendimento da formação da Nação e da Sociedade brasileira.

Assim, destaca-se, por um lado, uma produção intelectual voltada à recuperação de valores nacionais e um pensamento preocupado com a participação histórica do "povo" (Capistrano). Por outro lado, ressalta-se um posicionamento atrelado aos interesses da elite agrária, o que no limite é o antípoda de um nacionalismo conciliador (Oliveira Vianna).

Outro aspecto a ser destacado é que na medida em que a análise honoriana a respeito desses autores se concretiza e ganha amplitude, a preocupação com o nacionalismo-liberal adquire maior contorno em sua obra, tornando-se o eixo decisivo para a leitura de sua interpretação da sociedade brasileira.

\footnotetext{
${ }^{137}$ Para citarmos apenas alguns trabalhos, ver: Amed (2004), Bastos e Moraes (1989), Werneck Vianna (2004) e Iglésias (2007).
} 


\section{1 - Formação do pensamento social brasileiro: o nacionalismo liberal de José}

\section{Honório Rodrigues}

As referências que José Honório Rodrigues faz, quanto ao legado de Capistrano de Abreu, ressalta sua preocupação frente aos setores da sociedade até então preteridos pela historiografia. Em relação à obra de Oliveira Vianna, destaca a base oligárquica de seu estudo acerca da sociedade. Destarte, o primeiro é proclamado como aquele que mostrou, com grande pertinência, o quanto o "povo brasileiro foi capado e sangrado". E o segundo, por sua vez, é retratado, do "alto de sua empáfia", como o representante do "ultra conservadorismo." (Rodrigues, 1988).

A mediação entre essas duas interpretações remete a uma concepção em que a organização burguesa da sociedade deveria ser conduzida por princípios políticos que oferecessem ao "povo", tantas vezes "capado e sangrado", uma melhor sorte. Porém, na lógica de funcionamento da sociedade brasileira, que ao longo de sua história conviveu com o "entulho colonial" (Rodrigues, 1966), sendo que esse só seria definitivamente superado pela prática conciliatória. Cabe lembrar que:

A conciliação tem raízes históricas profundas e data da dicotomia terrorismoamansamento que os brancos europeus tiveram que enfrentar aos primeiros contatos com os índios e negros, e das transigências aos antagonismos coloniais. Manifestara-se no convívio diário de tantas diferenças e divergências econômicas, sociais e culturais. As sucessivas gerações das minorias dominantes no Brasil tinham aprendido a conviver com multidões capadas e sangradas e se não tinham podido evitar todo o processo histórico incruento muito fizeram para escamoteá-las de seus direitos, sem levá-las ao desespero. (Rodrigues, 1965: 50).

A conciliação, que convive bem "com tantas diferenças", não procurava estabelecer forma de integração e superação da condição de desespero que o "povo" enfrentava. O "moinho de gastar gente", "138, que formara-se no Brasil com o "sistema escravista" (Ribeiro, 1995), é a base da condição subalterna em que o "povo" foi

\footnotetext{
${ }^{138}$ O intelectual Darcy Ribeiro explica que: "A empresa escravista, fundada na apropriação de seres humanos através da violência mais crua e da coerção permanente, exercida através de castigos mais atrozes, atua como uma mó desumanizadora e deculturadora de eficácia incomparável. Submetido a essa compreensão, qualquer povo é desapropriado de si, deixando de ser ele próprio, primeiro, para ser ninguém ao ver se reduzido a uma condição de bem semovente, como um animal, de carga; depois, para ser outro, quando transfigurado etnicamente na linha consentida pelo senhor, que é a mais compatível com a preservação dos seus interesses." (Ribeiro, 1995: 118).
} 
lançado, sem que houvesse uma ação, por parte das lideranças políticas, para sua integração à sociedade de classes.

É nessa sociedade que, a partir da perspectiva de um intelectual preocupado com os obstáculos que dificultariam que um determinado projeto modernizante se completasse, constituem-se as "linhagens do pensamento social e político". ${ }^{139}$ Todavia, a participação da "intellingetsia" é determinante para a compreensão do movimento social que melhor explica esta sociedade, nesse sentido, é fundamental a escolha de "clássicos" do pensamento social, pois estes necessitam vir à baila para que se resgate de forma mais fidedigna a sua validade na determinada conjuntura político-social ${ }^{140}$. No caso de José Honório Rodrigues, tal conjuntura seria aquela que plasmou o ideário nacional-desenvolvimentista do decênio de 1950 e durou até o contexto do golpe civil militar de $1964^{141}$.

Tratava-se de um momento da história do país em que "corações e mentes" eram requisitados para fazer parte de um processo em que com seria possível levar o Brasil ao tão almejado "desenvolvimento". Nesse sentido, o decênio de 1950, mais especificamente a segunda metade dos anos de 1950, contou com uma expressiva

139 Segundo o professor Gildo Marçal Brandão, a renovação das disciplinas que investigam a amplitude dos fenômenos sociais no mundo moderno acabou possibilitando o aparecimento: "de uma área de pesquisa que vem sendo chamada, com maior ou menor propriedade, de pensamento social no Brasil ou de pensamento político brasileiro. (...) Visto retrospectivamente, os seus contornos nunca foram muito claros: como se trata de área de fronteira, acolhendo orientações intelectuais provindas das diversas ciências humanas, o estudo do pensamento político-social estabeleceu-se aqui, como em todo o mundo, no cruzamento de disciplinas tão variadas como a antropologia política e a sociologia da arte, a história da literatura e a história da ciência, a história das mentalidades e a sociologia dos intelectuais, filosofia e a teoria política e social e a história das idéias e das visões de mundo. Essa superposição talvez fosse inevitável no caso de um país de capitalismo retardatário como o nosso, uma vez que o tratamento da literatura, da arte, da cultura e das ciências aqui praticadas acaba tendo uma importante dimensão política por força da relação urgente que se estabelece entre a formação da cultura e a formação da nação." (Brandão, 2007: 22).

${ }^{140}$ Com relação ao necessário comprometimento intelectual nos anos 50, Florestan Fernandes tece os seguintes comentários: "Acima de tudo, procuramos ressaltar que o conhecimento científico precisa e deve ser obtido de acordo com cânones que não podem ser "omitidos" ou "simplificados". Há vários modelos de explicação científica da realidade. Nenhum, porém, comporta reduções ilimitadas. Além de dado limite, deixa-se de proceder cientificamente, se persistir a intenção de simplificar. Portanto, todo o país subdesenvolvido, que quiser sair dessa condição sob o impulso da ciência, só pode optar por um caminho - o da verdadeira produção do verdadeiro saber científico. (Fernandes, 1963: 43).

${ }^{141}$ Em interessante painel do contexto de 1950 até o golpe civil militar de 1964, os professores da PUCRJ Oswaldo Munteal, Jacqueline Ventapane e Adriano de Freixo argumentam que: "Nos anos de 1950, passava a ser construída uma nova categoria para pensar o Brasil e a América Latina - o subdesenvolvimento, um conceito elaborado pelos intelectuais que participavam da CEPAL, e que teve Celso Furtado como um de seus principais formuladores. Esta nova matriz de pensamento afetaria outros campos do conhecimento, como a Sociologia e a História, voltando-se o debate para a pesquisa sobre a dualidade entre o antigo e o moderno e as resistências eternas à mudança. $\mathrm{O}$ projeto nacionaldesenvolvimentista se desenvolveu a partir destes questionamentos. (...) O golpe de 1964 acabou interrompendo esse avanço nacional-democrático então em curso, colocando o país no caminho do desenvolvimento dependente, apoiado no capital internacional e em ajuste com o sistema de poder mundial." (Munteal, Ventapane e Freixo; 2006: 22). 
participação de intelectuais no que concerne ao posicionamento a ser adotado, conforme explica o professor André Botelho:

É certo que na década de 1950 dava-se continuidade ao debate sobre as vias de consolidação da ordem social moderna no Brasil que vinha das décadas anteriores, porém não sem alterar as formas e os efeitos cognitivos, estéticos e políticos com que esse empenho se desenvolvera até então. E não sem alterar igualmente as formas de sua própria auto-representação ou identidade social em fase inclusive das novas mediações institucionais e da rotinização de inovações culturais e políticas que então se cristalizavam. Ainda que a modernização conservadora então em curso, ao mesmo tempo em que tornava mais complexas as relações entre intelligentsia e sociedade, não afrouxasse as interdependências entre cultura e política nas mais diferentes esferas sociais, isto é, sem que estas pudessem assumir exatamente autonomia, uma em relação à outra, como nas sociedades marcadas por revoluções burguesas clássicas. (Botelho, 2008: 16). (grifos nosso).

O papel que os representantes da intelligentsia no país acabaram assumindo, em grande medida, o contexto de grande agitação política e social que existiu na década de 50, impulsionada pelo crescimento expressivo da economia, algo que levava alguns a acreditar que "estávamos entrando para o Primeiro Mundo" 142. Nunca é demais lembrar que a criação do Instituto Superior de Estudos Brasileiros (ISEB) é um exemplo de que houve uma efetiva participação dos intelectuais com o intuito de se criar um movimento que pudesse oferecer à sociedade um projeto de desenvolvimento respaldado por maiores preocupações com a sociedade civil e o "povo". Segundo Hélio Jaguaribe:

De todos os empreendimentos do ISEB o que teve maior repercussão pública e se constituiu no âmago da mensagem do Instituto foi sua proposta de um projeto nacional-desenvolvimentista para o Brasil, formulando os delineamentos gerais desse projeto e intentando mobilizar ideologicamente, em torno dele, os setores

\footnotetext{
${ }^{142}$ Em artigo conjunto os professores Fernando Novais e João Manuel Cardoso de Mello, afirmam que: "Os mais velhos lembram-se muito bem, mas os mais moços podem acreditar; entre 1950 e 1979, a sensação dos brasileiros, ou de grande parte dos brasileiros, era a de que faltava dar uns poucos passos para finalmente nos tornarmos uma nação moderna. Esse alegre otimismo, só contrariado em alguns rápidos momentos, foi mudando a sua forma. $\mathrm{Na}$ década dos 50 , alguns imaginavam até que estaríamos assistindo ao nascimento de uma nova civilização nos trópicos, que combinava a incorporação das conquistas materiais do capitalismo com a persistência dos traços de caráter que nos singularizavam como povo: a cordialidade, a criatividade, a tolerância.” (Novais e Mello, 2000: 560).
} 
progressistas da burguesia, da classe média e do proletariado. (...) O projeto nacional-desenvolvimentista tinha, como ponto de partida, o objetivo de equacionar três principais elementos: (1) realização, a mais acelerada possível, de um grande projeto integrado de desenvolvimento econômico, social, cultural e político do Brasil; (2) implementação desse projeto a partir das condições efetivamente existentes no Brasil e no mundo, na década de 1950 e dentro de uma concepção social-humanista, implicando uma democracia política e social e um encaminhamento da sociedade para a plena realização racional, livre e igualitária, das potencialidades individuais do homem. (Jaguaribe, 1979: 100).

O contexto analisado - criando as condições típicas para que o ideário do ISEB e de outras instituições como a Cepal fossem responsáveis pelo ideário a ser colocado em prática ao longo daqueles anos - foi decisivo para o país fosse pensado a partir de uma perspectiva nacionalista. ${ }^{143}$ Aspecto esse que conduziu também o pensamento social honoriano. ${ }^{144}$

\section{2 - A historiografia nacionalista: José Honório Rodrigues, intérprete de}

\section{Capistrano de Abreu.}

As primeiras análises de José Honório Rodrigues que podem ser identificadas como contribuições ao pensamento social brasileiro remetem ao intento de compreender a obra de Capistrano de Abreu. Cabe evidenciar que tal esforço repercutiu na publicação de vários artigos ${ }^{145}$.

\footnotetext{
${ }^{143}$ Cabe destacar que o nacionalismo foi discutido por vários intelectuais naquele contexto, exemplo disso são as afirmações de Nelson Werneck Sodré, em aula inaugural no ISEB em 1958. Momento em que afirma que: "Por que Nacionalismo? Porque, agora, são as forças econômicas externas o mais poderoso obstáculo ao nosso desenvolvimento, e aos seus aliados internos declinam em resistência, já não tutelam o País. Realizar-se nacionalmente, para um país de passado colonial, com estrutura econômica subordinada e interesses externos, corresponde a uma tarefa em muitos pontos idêntica à que os países europeus realizaram, no alvorecer da Idade Moderna. (...) O Nacionalismo apresenta-se, assim, como libertação. De seu conteúdo libertador provém o teor apaixonado de que se reveste e que leva os seus opositores a considerá-lo mais como paixão do que como política. Conviria acentuar, no caso, que não existe paixão pelo abstrato, e que o Nacionalismo traduz uma verdade - a verdade do quadro histórico, e a verdade é concreta." (Sodré, 2006: 107).

${ }^{144}$ Cabe mencionar que José Honório Rodrigues é vinculado por alguns dos estudiosos do ISEB como pertencente ao espaço de sociabilidade daquela instituição, segundo Caio Navarro de Toledo: "Muitos intelectuais renomados estiveram relacionados com as atividades e projetos isebianos: entre eles, podem ser mencionados: Roberto de Oliveira Campos, Celso Furtado, Anísio Teixeira, Hermes Lima, Gilberto Freyre, Fernando Azevedo, José Honório Rodrigues, Miguel Reale etc." (Toledo, 1986: 226).

${ }^{145} \mathrm{O}$ número de obras referentes à produção de Capistrano de Abreu realizada por José Honório Rodrigues é extensa. Dentre elas citamos: "Capistrano de Abreu e a historiografia brasileira". In: História e historiadores do Brasil, São Paulo: Fulgor, 1965, pp. 43-53; "Capistrano de Abreu e a Alemanha". In:
} 
O historiador cearense nasceu em 1853, em Maranguape, no Ceará, e teve uma formação basicamente autodidata. Veio para o Rio de Janeiro e, em 1879, aos 26 anos, ingressou na Biblioteca Nacional em concurso público, passando a ter a oportunidade de conhecer as fontes diretas da História do Brasil. Nesse período, sua publicação estava concentrada na crítica literária, o que rapidamente perdeu espaço, a partir daquele momento, para os estudos históricos:

Ampliando seu conhecimento das fontes, lendo os grandes autores, estudando Geografia, História, Economia, Filosofia e Linguística. Desde então começou a almejar a cátedra de História do Brasil do Colégio Pedro II, o que só surgiu em 1883. Os anos na Biblioteca Nacional consolidaram o seu conhecimento histórico. (Rodrigues, 1982: 228).

O período da Biblioteca Nacional também lhe permitiu participar de um grande empreendimento bibliográfico: o Catálogo da Exposição de História do Brasil. Essa empreitada, juntamente com o jornalismo, foi de grande estima para o desenvolvimento intelectual do historiador cearense. Entre as obras de Capistrano de Abreu, o necrológio publicado no Jornal do Commercio, por conta da morte de Francisco A. Varnhagen, em 1878, foi o que mais chamou a atenção de José Honório.

Porém, é devido à contribuição historiográfica de Capítulos da História Colonial no tocante às discussões sobre tradição histórica no Brasil que José Honório coloca Capistrano em um patamar de relevo entre os intelectuais nacionais. Para o historiador carioca é nessa obra que podemos apreciar seus aportes especiais à periodização, à crítica histórica e à pesquisa. Assim, realça a contribuição de Capistrano de Abreu enfatizando seu papel inovador na historiografia brasileira, tanto por seu estudo minucioso acerca do período colonial, quanto por incorporar, em sua análise, os setores subalternos.

Este homem que nunca certificou coisa senão de muita aprovada e por documentos que mereciam fé, nem recontou mais largo que devia, antepondo a simples verdade à formosa falsidade, teve a mais austera dúvida de republicar

História e historiografia, Petrópolis: Vozes, 1970, pp. 175-190; "Periodização da história do Brasil". In: Teoria da história do Brasil, São Paulo: Companhia Editora Nacional, 1978, 125-144; "Um historiador caboclo e sua obra: Capistrano de Abreu". In: História combatente, Rio de Janeiro: Nova Fronteira, 1982, pp. 226-232. Além dos vários prefácios das obras de Capistrano de Abreu: Ensaios e estudos, $1^{\mathrm{a}}$ a $4^{\mathrm{a}}$ séries, Rio de Janeiro: Editora Civilização Brasileira, 1976; Correspondência, $1^{\text {a }}$ a $3^{\circ}$ volumes, Rio de Janeiro: Editora Civilização Brasileira, 1976, Caminhos antigos e povoamento, Rio de Janeiro: Editora Civilização Brasileira, 1977 e Capítulos de História Colonial, Rio de Janeiro: Editora Civilização Brasileira, 1976. 
seus Capítulos de História Colonial, obra única, exemplar e modelar como síntese e composição, um livro que respondia às incertezas, satisfazia as dificuldades, colhia, informava, concluía e resumia o que de melhor se sabia de nossa formação colonial. Não é um livro que se compara; é um livro que se distingue na historiografia brasileira, escrito numa linguagem simples, branda, enxuta, onde havia doutrina que persuadia compreensão que se fazia perceber e novidade apertada, colhida na vastidão sem fim de suas pesquisas. Não acumulava só fatos, mas com sua intuição compreendia os homens e suas atividades, tornando vivo o recontamento. (Rodrigues, 1965: 43).

Quando pela primeira vez teve a ideia de escrever a respeito da história do Brasil, Capistrano ainda morava em Maranguape, onde teve contato com a produção de Buckle, que lhe empolgara de forma definitiva. O historiador cearense descreve da seguinte forma esse momento de sua formação intelectual em carta endereçada ao Barão do Rio Branco em 1890, nesta aponta explica que:

Dou-lhe uma grande notícia (para mim): estou resolvido a escrever a história do Brasil, não a que sonhei a muitos anos no Ceará, depois de ter lido Buckle, e no entusiasmo daquela leitura que fez época em minha vida, - uma história modesta, a grandes traços e largas malhas até 1807. Escrevo-a porque posso reunir muita coisa que está esparsa, e espero encadear melhor certos fatos, e chamar atenção para certos aspectos até agora menos prezados. Parece-me que poderei dizer algumas coisas novas e pelo menos quebro os quadros de ferro de Varnhagem que, introduzidos por Macedo no Colégio de Pedro II, ainda hoje são a base de nosso ensino. As bandeiras, as minas, as estradas, a criação de gado pode dizer-se que ainda são desconhecidas, como, aliás, quase todo o século XVII, tirando-se as guerras espanholas e holandesas. (Abreu, 1976: 412).

Cabe lembrar que para seu ingresso como docente no Colégio D. Pedro II, Capistrano escreveu uma obra que virou marco na historiografia brasileira, isto é, $O$ Descobrimento do Brasil. Portanto, antes da publicação dos "Capítulos" já conseguira resultado expressivo como autor de um pensamento social e historiográfico. Mesmo não tendo a contundência daquela obra de 1907, a tese para o ingresso na Cadeira de História do Brasil do Colégio D. Pedro II foi um marco para seu tempo. Com a obra a tentativa em procurar aspectos inovadores e, principalmente, que tivessem como característica a ruptura da prática em tratar a História como uma forma tradicional, ou 
seja, não ficar restrito a única possibilidade interpretativa. Outro aspecto, além do apuro em selecionar documentos históricos de relevância, visava ampliar o mote de leitura da sociedade brasileira. A tradição de Varnhagen sofre aqui uma inflexão, pois a tentativa é de identificar aspectos de "ruptura e não de continuidade." (Rodrigues, 1999).

A respeito do concurso e da referida monografia, Honório tece os seguintes comentários:

Em 1883, quando Capistrano de Abreu era funcionário da Biblioteca Nacional e estava em divergência com o novo diretor, surgiu-lhe uma grande oportunidade, que ele decidiu aproveitar. Abriu-se o concurso para a vaga de professor de História do Brasil no Imperial Colégio Pedro II e Capistrano apresentou-se como candidato exatamente com o Descobrimento do Brasil e seu desenvolvimento no século XVI. (...) Aprovado no concurso, a tese logo ganhou destaque, pois escrita em curto espaço de tempo era realmente algo de novo e inédito na historiografia brasileira. (Rodrigues, 1999: LXXXI).

Em carta de 20 de maio de 1924, endereçada a Paulo Prado, Capistrano de Abreu afirma, quanto à ideia de escrever os "Capítulos", que: "Sabe que há hoje exatamente 50 anos tive a primeira idéia de escrever uma história do Brasil". (Abreu, 1976: 11). Com o trabalho na Biblioteca Nacional, esse entusiasmo aumentou, pois the propiciou o estudo dos Conselhos Ultramarinos e outros importantes documentos. Sua tarefa árdua valeu uma obra que supera a de Varnhagen e iniciou um marco na produção historiográfica brasileira. Em 7 de janeiro de 1907, Capítulos de história colonial já estava pronto. (Rodrigues, 1976).

Esta produção era única e pioneira, pois até então o que se valorizava eram as atitudes privadas e seu imediatismo quanto ao legado histórico, datas, mitos, heróis - homens que com sua bravura eram os responsáveis pela "história dos vitoriosos" (Rodrigues, 1970: 177). A partir de Capistrano, o povo "capado e sangrado" 146 , que sempre foi hostilizado, ganha espaço na historiografia. Isso revela a atualidade de seus textos, haja vista que demonstrava clareza no domínio dos fatos, poder de articulação e generalização, bem como sagacidade ao abordar as novas

\footnotetext{
${ }^{146} \mathrm{Na}$ correspondência de Capistrano de Abreu, uma das cartas mais expressivas é aquela em que destaca a condição do povo brasileiro oprimido ao longo de sua existência e a falta de preocupação das lideranças políticas em relação a esse povo. (Abreu, 1976: 211).
} 
questões impostas por seu tempo apenas para evitar a rima entre a atualidade, sagacidade e realidade. Enfim, tínhamos um pensamento lúcido e progressista.

\section{Afirma José Honório Rodrigues:}

Não estudou capitães, governadores, vice-reis, como ensinou a seu único discípulo particular Afonso d'E.Taunay, insistindo para que estudasse a sociedade, a economia, via claro que não é biografia, e que não se deve personalizar a história, mas estudar as forças impessoais, sociais e econômicas, políticas. (...) A valorização do estudo do sertão, do Brasil interno, da internação da História do Brasil, tem o efeito de contrapor à internalização da nossa historiografia pelos brasilianistas. Ao preferir a História do Brasil de Frei Vicente de Salvador à História da América Portuguesa de Sebastião da Rocha Pitta, ele dava outra lição, não somente nacionalista, mas, sobretudo de crítica, pois a segunda é a sociedade, é a gente, é a economia. (Rodrigues, 1982: 231).

O nacionalismo de Capistrano de Abreu é realçado por José Honório como fonte de proposição crítica frente ao legado que a produção historiográfica havia nos deixado até então, além disso, o historiador carioca, no legado do historiador carioca que esse via o país como uma sociedade de classes, condicionada, destarte, por relações de poder de classe, independentemente da particularidade que essa dominação tomava (econômica, racial, política, etc.).

Uma sociedade que não se sentia culpada com os crimes que cometeu e comete nesta disparatada desproporção entre o esbanjamento e a miséria. O solo foi encharcado de sangue com as matanças de índios, as repressões às revoltas negras, e as rebeldias da gente mais humilde e modesta do Brasil. Foi por lê-lo várias vezes que senti que a História do Brasil não era cordial, era cruel e cruenta, e que nunca nenhuma Revolução foi vitoriosa, mas só as ContraRevoluções, ao contrário das grandes potências mundiais, na variedade de seu predomínio. A morbicidade da classe dominante, sua tradição de irresponsabilidade para com a comunidade, e a falta de solidariedade social, a chaga da escravidão transparecem nos seus Capítulos de História Colonial. (Rodrigues, 1982: 231).

Parece-nos que a força da obra de Capistrano, segundo José Honório Rodrigues, se deve à tradição do pensamento nacionalista, que foi, aliás, a base de preocupação do historiador cearense. Assim, segundo palavras do próprio autor de História da História do Brasil, a tendência era não qualificar o processo histórico no 
país como mera relação cordial; “... que a História do Brasil não era cordial, era cruel e cruenta" e de levar adiante uma crítica à sociedade brasileira e a suas inadequações quanto à tradição do "liberalismo político antipovo", que ao nosso entendimento, acabou sendo externado no legado tanto de Capistrano como de José Honório Rodrigues.

É interessante notar que a recuperação que José Honório faz da produção de Capistrano é resultado de suas preocupações a partir dos anos de 1950, quando a discussão acerca do nacionalismo ganha maior espaço em sua obra. $\mathrm{O}$ ambiente de reflexão e diálogo do autor de Conciliação e reforma no Brasil, naqueles anos, faz com que sua vinculação intelectual seja refratária a conceituações que não estejam amarradas à tradição liberal mais próxima dos interesses do povo.

Assim, o resgate da obra de Capistrano se insere num contexto em que as preocupações políticas e sociais vinham delineando e influenciando, de forma decisiva, o percurso intelectual de José Honório Rodrigues. De qualquer forma, coube ao jovem de 25 anos, no ano de 1878, realizar uma mudança expressiva na forma de escrever a História do Brasil. No necrológio de Varnhagen, publicado no Jornal do Commercio em 20 de dezembro de 1878, Capistrano destacava a obra do pai da historiografia brasileira apontando a mudança de foco, deixando de lado os reis, governadores, capitães-mores, e ressaltando as formas de dominação dos portugueses sobre os nativos, o aumento da população, as descobertas das minas.

Para José Honório a tradição conservadora, que tem em Francisco Adolpho Varnhagen um dos primeiros expoentes, é aperfeiçoada por Capistrano de Abreu, o primeiro a apontar as dificuldades para que a unidade fosse mantida na sociedade brasileira. Em passagem Capítulos de História Colonial, argumenta que:

A desafeição entre as três raças e respectivos mestiços lavrava dentro de cada raça. O negro ladino e crioulo olhava com desprezo o parceiro boçal, alheio à língua dos senhores. O índio catequizado, reduzido e vestido, e o índio selvagem ainda e livre e nu, mesmo quando pertencentes a mesma tribo, deviam sentir-se profundamente separados. O português vindo da terra, o reinol, julgava-se muito superior aos portugueses nascido nestas paragens alongadas e e bárbaras; o português nascido no Brasil, o mazombo, sentia e reconhecia sua inferioridade. (...) Em suma, dominavam forças dissolventes, centrífugas, no organismo social; apenas se percebiam as diferenças; não havia consciência de unidade, mas de multiplicidade. Só muito devagar foi cedendo esta dispersão geral, pelos meados do século XVII. Reinóis e mazombos, negros boçais e 
negros ladinos, mamelucos, mulatos, caboclos, caribocas, todas as denominações, enfim, sentiram-se mais próximos uns de outros, apesar de todas as diferenças flagrantes e irredutíveis, do que do invasor holandês: daí uma guerra começada em 1624 e levada ao fim, sem desfalecimentos, durante trinta anos. (Abreu, 1976: 70).

Esses elementos conflitantes, oriundos de condições históricas e sociais diferenciadas, foram os responsáveis pela criação de uma ordem social típica. Tamanha divergência resultou em um Estado que manteve a unidade territorial sempre defendida como "legítima aspiração nacional", ainda que uma de suas maiores dificuldades tenha sido fazer a ordem liberal democrática triunfar.

A base epistemológica de Capistrano, colidindo com a tradição imperante no país, estavam pautadas pelo germanismo. Assim, o contato com os autores alemães possibilitou-lhe uma crítica ao positivismo, aproximando-o mais de uma orientação geográfica, com estudos que ampliam o referencial teórico e prático. "As traduções de Wappoeus e Sellin junto às leituras de Ratzel, Peschel e Maull mostram a decisiva orientação geográfica e encaminham seu espírito para quadros teórico-práticos mais concretos que não reduzem o conhecimento histórico ao conhecimento da ciência natural" (Rodrigues, 1970: 178). Com relação à historiografia, foi nos métodos de seminário de Ranke ${ }^{147}$ e na antropogeografia de Ratzel ${ }^{148}$ que buscou os elementos de investigação e interpretação dos fatos.

Com essa leitura, José Honório Rodrigues eleva Capistrano de Abreu à condição de historiador que modernizou a historiografia e contribuiu para que a história ocupasse um lugar de primazia em relação aos modos de identificar os destinos do povo (muitas vezes conturbados e com pouco destaque). Tratava-se de formas de interpretação que, até o surgimento de Varnhagen, não se encontravam de forma organizada e sistemática na historiografia do país.

Não será exagero dizer que Capistrano de Abreu soube elevar-se realmente com uma altura ainda não atingida por nenhum historiador brasileiro. Ele anota a

\footnotetext{
147 Nascido na Prússia em 1795, morreu em 1886 em Berlim, num ambiente tipicamente luterano. Leopold Von Ranke foi um dos precursores do chamado historicismo. Para maiores detalhes do historicismo representado por Ranke, ver: Holanda, Sérgio Buarque. "Introdução: O atual e o inatural em L. Von Ranke”. In: Ranke, São Paulo: Ática, 1979.

148 O geógrafo alemão Friedrich Ratzel (1844-1904) deixou um legado que representou um papel fundamental no processo de sistematização da geografia moderna. Sua obra contém a primeira proposta sistemática de discussão dos problemas humanos. Foi de sua autoria a formulação de uma geografia do homem, sendo considerado o inaugurador da antropogeografia.
} 
deficiência fundamental de Varnhagen, sua falta de percepção filosófica. É ao notar essas grandes cesuras, ao caracterizá-las e ligá-las, que ele mostra o elemento propriamente filosófico da história do Brasil e demonstra sua penetrante capacidade teórica, que o distingue de qualquer pedante, de qualquer rato ou burocrata da história para elevá-lo ao nível de um verdadeiro historiador. Os grandes grupos concentrados distinguem-se nitidamente. Mas não é só nos fundamentos sócio-econômicos ou nos subfundamentos naturais e antropológicos que ele vai buscar a particularidade histórico-social de um período. É também nos fins, nas regras de vida, nos sentimentos e idéias de cada círculo que ele busca as fronteiras de suas épocas. Fundamentos econômicos e psicológicos ligados tão estreitamente, entrevistos em conjunto, mostram a profundeza das revelações de Capistrano de Abreu. (Rodrigues, 1978: 136).

Capistrano de Abreu procura compreender o movimento que a sociedade segue com o intuito de ampliar sua concepção histórica. Ficar restrito a ideia de "mão única", ou seja, de que somente os "grandes proprietários teriam voz", portanto, não é sua preocupação. Há, por parte de José Honório, um esforço em analisar o pensamento de Capistrano pertencendo a uma família de interpretação, no caso, herdeiro de um grupo capaz de explicar a trajetória de formação do pensamento historiográfico brasileiro. Sintomático disso é que o historiador cearense, marcado por uma base historiográfica que fora criada por Francisco Adolpho Varnhagen ${ }^{149}$, nesse sentido. José Honório explica que:

Do ponto de vista da periodização em Capítulos da História Colonial, distribuiu mais a matéria do que periodizou. Ainda assim, a divisão em onze capítulos caracterizava muito bem cada período, que constituía um conjunto bem delimitado e configurado, distinguindo-se claramente não pelo título, mas pela

\footnotetext{
${ }^{149}$ O professor Arno Wehling explica que: "As interpretações de Varnhagen fundamentavam-se quase sempre em "descobertas", ou seja, em filões documentais ignorados ou esquecidos por seus predecessores. O "preconceito do inédito", extremamente forte na historiografia historista, supunha a intimidade com as fontes arquivísticas, entendida como indício seguro para a informação correta e o alcance da verdade histórica; subjacente a este preconceito encontrava-se o suposto idealista de uma realidade preexistente imutável, aguardando sua correta identificação pelo sujeito. A afirmação da cientificidade da história num contexto intelectual de conhecimentos com fronteiras cada vez mais bem definidas passava, assim, obrigatoriamente, pelo estabelecimento de um corpus documental, a partir do qual seria construído o conhecimento histórico, uma vez que todas as demais opções eram apenas aproximações imperfeitas deste noúmeno fenomênico que a documentação revelava. (...) As revelações de Varnhagen foram muitas e têm sido resgatadas desde Silvio Romero e Capistrano de Abreu até Clado Ribeiro Lessa e Wilson Martins, Américo Jacobina Lacombe e José Honório Rodrigues". (Wehling, 1999: 153) (Grifos nosso)
} 
substância o capítulo que precedia do que sucedia. É claro que ao adotar tal divisão Capistrano não obedeceu ao intuito de periodizar, já que não the seria difícil seguir neste livro a distinção feita em 1882 de seis períodos perfeitamente delineados. (...) Ao próprio Capistrano não passariam despercebidas a inexpressividade de certos rótulos e a falta de uniformidade dos fundamentos divisórios. Na caracterização dos onze capítulos, alguns obedecem a critérios exclusivamente político-administrativos, outros juízos geográficos, outros a históricos. Esta crítica tem que levar em conta, em primeiro lugar, a quase impossibilidade, nessa época (1906-1907), de se obedecer exclusivamente a um critério uniforme de classificação; em segundo lugar, esta crítica atinge mais os títulos que aos períodos, que se sucedem cronologicamente, embora não inteiramente censurados pelos fundamentos sócio-econômicos ou pelos fundamentos naturais e antropológicos que distinguem a categoria histórica de um período. (Rodrigues, 1976: XXXIII).

O argumento, nesse caso, é de uma possível ingenuidade na análise, pois esta estaria limitada em sua ênfase e análise metodológica ${ }^{150}$. O que teria maior repercussão seria o "estilo retórico" (Carvalho: 1999:127). Para o caso de Capistrano, a particularidade da análise parece de outra monta. Em capítulo explicativo de sua obra, o VIII “Guerras flamengas", temos a seguinte argumentação:

As relações entre Portugal e Flandres, iniciadas desde a Idade Média, continuaram ainda depois de descoberto o caminho marítimo das Índias e achado e colonizado o Brasil. Iam os flamengos a Lisboa adquirir as drogas e os gêneros exóticos, apenas desembarcados, e retalhavam-nos pela vasta clientela do Norte e Ocidente da Europa, poupando canseiras e garantindo lucros imediatos aos portugueses; estes, além do dinheiro de contado, proviam-se graças aos seus fiéis fregueses, de cereais, peixe, salgado, objetos de metal, aparelhos náuticos, fazendo finais. Modificou-se esta situação vantajosa para ambas as partes quando a monarquia espanhola abarcou a península inteira e os inimigos de Castela passaram a ser os de Portugal. Em 1585, Felipe II mandou confiscar os navios flamengos ancorados em seus portos, aprisionando-lhes as tripulações. O mesmo se fez em 90, 95 e 99. (Abreu, 1976: 74).

\footnotetext{
${ }^{150}$ Os argumentos seguem as assertivas de José Murilo de Carvalho, "História intelectual no Brasil: a retórica como chave de leitura” In: Topoi, Rio de Janeiro: 1999.
} 
Temos nessa passagem outra inovação de Capistrano de Abreu, pois a historiografia brasileira até então não abordava esse período de nossa história sem mostrar o quanto aquele contexto havia sido nefasto para o Estado português. Essa peculiaridade de inovação também aparece no capítulo IX, "O sertão", no qual se encontra o seguinte comentário:

A invasão flamenga constitui mero episódio da ocupação da costa. Deixa-a na sobra a todos os respeitos o povoamento do sertão, iniciado em épocas diversas, de pontos apartados, até formar-se uma corrente interior, mais volumosa e mais fertilizante que o tênue fio litorâneo. (...) Podemos começar pela capitânia de São Vicente. O estabelecimento de Piratininga, desde a era de 1530, na borda do campo, significa uma vitória ganha sem combate sobre a mata, que se reclamou alhures o esforço de várias gerações. Deste avanço procede ao desenvolvimento peculiar de São Paulo. O Tietê corria perto; bastava seguir-lhe o curso para alcançar a bacia do Prata. Transpunha-se uma garganta fácil e encontrava-se o Paraíba, encaixado entre a serra do Mar e a Mantiqueira, apontando o caminho do Norte. Para o Sul estendiam-se vastos descampados, interrompidos por capões e até manchas de florestas, consideráveis às vezes, mas incapazes de sustentarem o movimento expansivo por sua descontinuidade. A Este apenas uma vereda quase intransitável levava à beira-mar, vereda fácil de obstruir, obstruída mais de uma vez, tornando a população sertaneja independente das autoridades da marinha, pois um punhado de homens bastava para arrostar um exército, e abrir novas picadas, domando as asperezas da serra, rompendo as massas da vegetação, arrostando hostilidade dos habitantes, pediria esforços quase sobre-humanos. (Abreu, 1976: 99).

Tal capítulo discorre sobre a formação territorial mais ampla do país, destacando o papel das Bandeiras nessa tarefa, ou seja, sua responsabilidade em escravizar os indígenas para a manutenção da lógica escravocrata do sistema mercantil português ${ }^{151}$. A descrição de Capistrano visa a explicar como o sertão brasileiro foi constituído a partir da iniciativa dos bandeirantes em "conhecer o sertão até então desconhecido" (Abreu: 1976).

\footnotetext{
${ }^{151}$ A definição é do próprio Capistrano Abreu "Bandeiras eram partidas de homens empregados em prender e escravizar o gentio indígena. $\mathrm{O}$ nome provém talvez do costume tupiniquim, referido por Anchieta, de levantar-se numa bandeira em sinal de guerra. Dirigia a expedição um chefe supremo, com os mais amplos poderes, senhor da vida e morte de seus subordinados. Abaixo dele com certa graduação marchavam pessoas que concorriam para as despesas ou davam gente". (Abreu, 1976: 99).
} 
A tradição da forma analítica de Capistrano de Abreu não é explicitada por José Honório Rodrigues. O vínculo que a historiografia instituída pelo historiador cearense coloca em prática é calcado no princípio da neutralidade axiológica típica dos positivistas. A historiografia positivista, que o próprio José Honório Rodrigues discute, ${ }^{152}$ é a base central das argumentações de Capistrano, que como herdeiro de Varnhagen e leitor de Ranke e Buckle, encontrou nesses autores a "chave heurística" de discussões para sua História do Brasil. É importante destacar que devido ao espaço adquirido pela historiografia francesa e a sua forma de repudiar a "neutralidade axiológica" positivista, não encontramos hoje espaço para que Capistrano tenha condições de ser um historiador que faça escola. Se for exagero considerar José Honório Rodrigues como herdeiro da tradição positivista de Capistrano, podemos ao menos dizer que ele resgata esse historiador para fazer valer seus interesses de discussão de uma vertente nacionalista da História, já que é nos escritos do autor de Capítulos da História Colonial que melhor se encontra um comprometimento com a História como prática metodológica de força para compreensão da sociedade brasileira.

A profusão do positivismo nas obras de Capistrano nos parece uma limitação do seu legado, ainda que se considere a sua inquestionável importância quanto à utilização de documentos para descortinar momentos significativos da História do Brasil e sua postura em favor de um maior resgate de agentes históricos até então deixados em segundo plano pela historiografia do XIX.

Cabe lembrar que mesmo o positivismo tem início com um ideário associado aos interesses da burguesia antiabsolutista da transição do século XVIII para

152 José Honório, em História genética ou científica. In: Teoria da história do Brasil, São Paulo: Companhia Editora Nacional, 1978, afirma: "A figura dominante e mais alta personalidade do renascimento dos estudos históricos alemães é Leopold Ranke, cuja compreensão do mundo histórico o torna o maior historiador do mundo moderno. Ranke afirmou, na Europa, a supremacia da erudição alemã e jamais alguém se aproximou tanto quanto ele do verdadeiro historiador. Os serviços que prestou à história podem assim ser resumidos: dissociou o estudo do passado das paixões do presente e pretendeu narrar a história como na realidade foi. Estabeleceu a necessidade de basear-se a construção histórica em fontes estritamente contemporâneas. Lançou os fundamentos da crítica histórica no seu primeiro livro, a História dos povos românicos e teutônicos, que lhe deu reputação internacional. (...) Como legado dessa obra os historiadores do século XIX com o método filológico da crítica das fontes e a ampla utilização das disciplinas auxiliares sabiam como fazer seu trabalho, segundo seus próprios meios, e não corriam mais o risco de pretender assimilar o método histórico ao natural. As seduções e imposições vindas pouco depois de Augusto Comte e do evolucionismo encontrariam a indiferença dos historiadores competentes, de posse de um método seguro e apurado. Ranke enriqueceu a consciência histórica, elevando-a uma etapa mais alta do que a conhecida até então. A influência do positivismo de Comte rompia toda a evolução do pensamento histórico, reduzido à descoberta e colheita dos fatos, sobre os quais o sociólogo, como um super-historiador, cientificamente estabelecia as relações de causa efeito e formulava as leis gerais do desenvolvimento humano. O mundo histórico era esquematizado com idéias gerais empiricamente fundamentadas e só causal e geneticamente podia ser compreendido. Uma das leis fundamentais é a dos três estados.” (Rodrigues, 1978: 392). 
o XIX. Nesse caso, os teóricos de maior vulto são Condorcet e Saint-Simon, porém será com a figura de Auguste Comte que o positivismo ganha seu caráter conservador dos princípios de defesa da ordem estabelecida ${ }^{153}$. É com esse pensador do período contra-revolucionário, surgido com o advento da restauração Bourbon e do avanço liberal na França de 1830, que teremos o cenário típico do pensamento contrário ao socialismo utópico de Condorcet e Saint Simon (Lowy, 2003: 23).

Com Comte teremos a instituição de uma "física social" "154 desprovida de valores que possam interpretar a sociedade com ideias negativas - iluminismo, socialismo, anarquismo, entre outras. A neutralidade seria o princípio fundamental para a defesa da ordem social vigente. Nesse sentido, os fenômenos sociais seriam considerados, para efeito de seu estudo, como os fenômenos astronômicos, físicos, químicos e fisiológicos, ou seja, sujeitos às leis naturais invariáveis, cuja descoberta é o objetivo específico de suas pesquisas.

A recuperação da obra de Capistrano de Abreu por José Honório não leva em consideração a peculiaridade positivista da produção intelectual do historiador cearense. O objetivo é evidenciar um autor que discute em suas obras, de forma sistemática, a integração do povo como partícipe da História do Brasil, procurando uma

\footnotetext{
${ }^{153}$ Michel Lowy expõe que: “(...) O positivismo moderno nasceu como legítimo descendente da filosofia do Iluminismo. De todos os Enciclopedistas, é, sem dúvida, Condorcet quem contribuiu da maneira mais direta e imediata na gênese da nova corrente. Próximo dos fisiocratas e dos clássicos ingleses, Condorcet pensa que a economia política pode estar submetida a "precisão do cálculo" e ao método das ciências da natureza. Mas não se limita aos fatos econômicos e passa a generalizar esta démarche: o conjunto dos fenômenos sociais está submetido "as leis gerais, necessárias e constantes" parecidas com as que regem as operações de natureza. Daí, a idéia de uma ciência natural da sociedade ou de uma "matemática social" baseada no cálculo das probabilidades. O estudo dos fatos sociais foi, por muito tempo, "abandonado ao acaso, à avidez dos governos, à astúcia dos charlatães, aos preconceitos ou aos interesses de todas as classes poderosas"; aplicando o novo método à moral, à política e à economia pública, pode-se "seguir nas ciências um caminho quase tão seguro quanto o das ciências naturais". Aliás, as ciências da sociedade procuram incessantemente aproximar-se deste "caminho das ciências físicas que o interesse e as paixões não vem perturbar. (...) Discípulo de Condorcet, Saint Simon vê no grande Enciclopedista o pensador ao qual a "ciência do homem deve seu último passo importante". Esta ciência do homem, apresentada como um ramo ora da física, ora da fisiologia, deve-se tornar positiva, quer dizer, utilizar os métodos das ciências naturais, "pois não existe fenômeno que não possa ser observado do ponto de vista da física dos corpos brutos ou do ponto de vista da física dos corpos organizados, que é a fisiologia." A própria política "tornar-se-á uma ciência positiva quando os que cultivam este importante ramo dos conhecimentos humanos aprenderem a fisiologia e quando eles não mais considerarem os problemas a resolver apenas como questões de higiene." (Lowy, 2003: 25).

${ }^{154}$ Segundo Auguste Comte: "Entendo por Física Social a ciência que tem por objetivo próprio o estudo dos fenômenos sociais, considerados com o mesmo espírito que os fenômenos astronômicos, físicos, químicos e fisiológicos, isto é, como submetidos às leis naturais invariáveis, cuja descoberta é o objetivo especial de suas pesquisas. Propõe-se, assim, explicar diretamente, com a maior precisão possível, o grande fenômeno do desenvolvimento da espécie humana, considerado em todas as suas partes essenciais; isto é, a descobrir o encadeamento necessário de transformações sucessivas pelo qual o gênero humano, partindo de um estado apenas superior das sociedades dos grandes macacos, foi conduzido gradualmente ao ponto em que se encontra hoje na Europa civilizada." (Comte, 1978: 53).
} 
ruptura com a produção intelectual até então atuante, o historiador cearense inova em oferecer uma contribuição na possibilidade de identificação de valores sociais associado a uma leitura da realidade brasileira e da participação do povo na construção da História do país.

O objeto de estudo de Capistrano é, nesse sentido, uma inovação se comparado a tradição em que se insere, porém, o mesmo não podemos afirmar a respeito do seu método de exposição. Suas limitações quanto a esse aspecto nos parecem bem específicas e claras. Ganham maior peculiaridade, nesse caso, suas preocupações quanto ao que é necessário evidenciar no estudo histórico, o que aponta para o interesse de um resgate do nacionalismo por parte de José Honório Rodrigues. O ideário nacionalista de Honório é o princípio que o leva ao resgate sistemático do legado de Capistrano, pois em sua obra a preocupação de escrever a História do Brasil o levou a destacar setores da sociedade que até então não eram levados em consideração.

A problemática central dessa aproximação, ou seja, Capistrano de Abreu pela lente crítica e nacionalista de Honório proporcionou que o primeiro ganhasse uma reedição da sua obra - que veio a público em 1976 - como uma interpretação do Brasil diferenciada daquelas até então realizadas. Entretanto, o que acreditamos ser o núcleo dessa aproximação é o quanto o historiador cearense preocupou-se em destacar a forma como o "povo" fora explorado e não recebeu nenhum tipo de auxílio por parte da elite dirigente. A condução da política realizada por parte dessa elite não amenizou a condição histórica do povo que, segundo a formulação emblemática de Capistrano, fora “... tantas vezes capado e sangrado".

José Honório Rodrigues realça esse aspecto da produção de Capistrano e o vincula à concepção radical de intérprete da sociedade. Assim, identifica no historiador cearense a preocupação em apontar os limites da sociedade brasileira, constituída para contemplar os interesses da Metrópole. A interpretação de Honório da realidade do país, considerada próxima ao "liberalismo democrático", vislumbra aqui um caminho possível de concepção social que atenderia aos seus anseios intelectuais de concretização de um liberalismo político integrador e sem preconceitos com o povo "capado e sangrado"

\section{3 - O pensamento ultraconservador de Oliveira Vianna: José Honório Rodrigues e a crítica à elite oligárquica}


Ao longo deste subitem pretendemos abordar as motivações que levaram José Honório Rodrigues a analisar a obra de Oliveira Vianna. O jurista fluminense foi identificado por Honório como representante do pensamento ultraconservador, pois suas preocupações voltavam-se, fundamentalmente, à tentativa de "glorificar o passado" e edulcorar os feitos dos grandes proprietários de terra. Acreditamos que a crítica realizada pelo autor de História da História do Brasil externa seu posicionamento nacionalista e sua defesa intransigente do liberalismo democrático.

A obra de Oliveira Vianna ganha cada vez mais espaço entre aqueles que pretendem realizar um estudo a respeito da formação do pensamento social brasileiro. Nesse sentido, Ângela Castro Gomes afirma:

Oliveira Vianna tornou-se inquestionavelmente um clássico do pensamento social brasileiro. Contudo, a vinculação de suas análises a uma proposta de Estado autoritário, somada a seu engajamento político à maquina do Estado autoritário do pós-30, por muito tempo desestimulou o debate em torno de sua obra, tachada em geral e com simplismo de reacionária e racista. No entanto, foram essas mesmas características que estimularam o interesse pela análise e reavaliação de sua ampla produção, que se estendeu de 1920 até sua morte, em 1951. (Gomes, 2009: 146).

Portanto, conforme o argumento de Gomes (2009), a retomada de estudos que procuram compreender a dimensão da obra de Oliveira Vianna, principalmente em relação a sua contribuição sobre as "interpretações do Brasil", revela preocupações que certos intelectuais tiveram a partir dos anos $90^{155}$. Além disso, o autor de Populações meridionais passa a fazer parte de um seleto grupo de intérpretes do Brasil, sendo analisado numa concepção de maior amplitude analítica, como a de Luiz Werneck Vianna. Desse modo, afasta-se de leituras que identificam sua obra como meramente racista e defensora do pensamento autoritário. Segundo Werneck Vianna:

Para Oliveira Vianna o estudo da singularidade brasileira tem como raiz as relações sociais aqui estabelecidas, especialmente as prevalecentes no mundo agrário. Contudo, não retida da sua Sociologia elementos de convicção que

\footnotetext{
155 O professor Bernardo Ricupero argumenta que: “A recepção da obra do jurista fluminense vai, progressivamente, se modificando. Um marco importante da mudança é a realização, em 1991, de um seminário num bastião do pensamento "progressista", a Universidade Estadual de Campinas (Unicamp). Muitas das interpretações a respeito de Oliveira Vianna já não ressaltam seu autoritarismo e racismo, que passam até a ser considerados como residuais na sua análise, e enfatizam, ao contrário, a perspicácia de seu julgamento sociológico, principalmente ao tratar de certos temas, como a questão agrária." (Ricupero, 2007: 70).
} 
neguem a possibilidade de realização dos ideais civilizatórios, mas sim uma forma particular da sua expressão. (...) Nesse sentido, Oliveira Vianna, apesar de muito longe dos temas de uma cultura libertária, inscreve-se numa posição que o leva a valorizar positivamente a história do país e seu próprio povo, malgrado sua adesão às teorias de superioridade racial, então em voga. (Werneck Vianna, 2004: 169).

O autor fluminense esteve vinculado, durante muito tempo, como já mencionado por Ângela Castro Gomes (2009) e Werneck Vianna (2004), à análise "racista" e "antipovo" da sociedade brasileira. Porém segundo os autores mencionados, priorizar essa interpretação seria uma redução quanto à possibilidade de melhor compreendermos a formação liberal do país. Ainda segundo Werneck Vianna:

A afirmação de Oliveira Vianna, que "somos distintos", ponto de partida de seus estudos de "história social", não soa como uma condenação - como nos americanistas -, e sim como uma orgulhosa declaração de princípios do iberismo do autor. Segundo ele, a noção de distinvidade teria desaparecido da consciência de nossas elites com a Independência. Caberia, então, retomá-la, a fim de redescobrir o sentimento das nossas realidades, tão sólido e seguro nos velhos capitães-generais da época da Colônia. (Werneck Vianna, 2004: 170).

No final dos anos 1970, José Honório lança o estudo a respeito da História do História do Brasil (obra em dois volumes sendo que o segundo em dois tomos). O primeiro, de 1979, faz um apanhado sucinto sobre a historiografia do período colonial, a obra ganha destaque, pois juntamente com Teoria da História do Brasil (1949) é um texto pioneiro no que diz respeito à produção da história da história no Brasil $^{156}$.

Todavia, o segundo volume dessa obra versa exclusivamente sobre a produção de Oliveira Vianna. Sem deixar dúvidas sobre o seu posicionamento, o

\footnotetext{
156 Segundo Rogério Forastieri: “(...) No que diz respeito especificamente à história geral da historiografia, o autor utiliza como fontes as histórias gerais da historiografia até então publicadas. Segundo o autor, a melhor maneira de conhecer o significado da história consiste no estudo da evolução da "idéia de história". Observa-se, nesta abordagem, uma inspiração próxima a Benedetto Croce e Robin G. Collingwood. A partir desta postura, José Honório Rodrigues caracteriza a evolução da historiografia segundo o que podemos considerar como variações na forma de apresentação do discurso histórico. $\mathrm{O}$ exemplo de José Honório Rodrigues mostra-nos que a preocupação em expor uma história geral da historiografia não se observa somente nas obras produzidas com essa finalidade, observa-se em muitos textos que a história geral da historiografia aparece muitas vezes como um suporte de argumentação e, nem por isso, deixa de ser importante para a compreensão de sua lógica e de sua validade." (Forastieri, 2001: 89).
} 
historiador carioca escreve A metafísica do latifúndio: o ultra-reacionário Oliveira Vianna, que vem a público em $1985^{157}$. Já na apresentação da obra, José Honório Rodrigues demonstra sua impressão acerca de Oliveira Vianna:

Oliveira Vianna produziu obras de interpretação muito louvadas e aceitas pela classe dominante, embora sejam passíveis de crítica pela sua posição política ultraconservadora, a favor da "nobreza" ou "aristocracia" rural, quer pelo desprezo pelo povo, quer pelo racismo arianista. (...) Ao contrário da corrente conservadora, que se origina em Varnhagen, Oliveira Vianna não possui o fetichismo dos fatos e dos documentos, nem o respeito pelas divisões temporais ou periódicas. Em sua obra não há cronologia. Ele não pesquisa, não traz uma novidade documental ou factual, mas sim se distingue pela originalidade da interpretação baseada nos mesmos documentos que Varnhagen usou. Da compilação parte para a análise. (Rodrigues, 1988: 27)

O centro da crítica de José Honório Rodrigues está na preocupação com a veracidade dos acontecimentos e a possibilidade de dialogar com os documentos históricos que, em seu entendimento, sedimentariam o caráter científico da produção de Oliveira Vianna. Todavia, o que o autor de Conciliação e reforma no Brasil não leva em consideração é que o jurista fluminense não tem a preocupação em "documentar", levando em consideração uma "livre interpretação dos fatos",. Honório afirma que:

Para Oliveira Vianna a interpretação é tudo, pois os fatos podem ser manipulados de acordo com os objetivos visados. Sua historiografia - que tem hoje novos e afamados cultores, cujos nomes não declaramos pelo princípio de só tratar dos mortos e não dos vivos - pretende usar o passado para orientação política do presente. Foi isso que fez Oliveira Vianna e com um êxito inigualado no Brasil. Ele é responsável intelectual pelo movimento estadonovista de 1937, de inspiração nazifascista, e pela contra-revolução de 1964, generalismo presidencial de caráter autoritário e repressivo. (...) Oliveira Vianna representa uma historiografia antidemocrática, antiliberal, que não é propriamente conservadora, mas uma degeneração do conservadorismo, reatora,

\footnotetext{
${ }^{157}$ Com relação às datas, cabe um esclarecimento: em entrevista concedida pela doutora Leda Boechat Rodrigues, na ocasião do falecimento de José Honório Rodrigues, ela afirma que a publicação integral da História da História do Brasil ficou comprometida devido aos problemas de saúde de José Honório. O volume 2, por exemplo, estava programado para sair em dois tomos, porém só foi concluído em 1985, tendo sua primeira edição em 1988. (Rodrigues, 1988).
} 
reacionária ou, como se dizia no Império, regressiva ou regressora. (Rodrigues, 1988: 2).

A obra de Oliveira Vianna acabou sendo tratada como um grande compêndio da produção mais retrógrada e reacionária, em outras palavras, é interpretada como uma forma de análise que vislumbra a história presa ao passado, ou seja, continuação de princípios históricos ligados à aristocracia incrustada ao Estado. Destacaremos aqui Populações meridionais e Evolução do Povo Brasileiro.

Populações meridionais do Brasil: história, organização, psicologia, no primeiro volume, populações rurais do centro-sul: paulistas, fluminenses, mineiros começa citando o argentino José Ingenieros ${ }^{158}$, o que na argumentação de José Honório é um fator desfavorável.

A propósito de um conflito de duas facções locais no interior do Estado do Rio de Janeiro, Oliveira Vianna ouviu dizer que iriam apelar para o governo da Bahia, o que levou o autor a aprender uma lição metodológica, que já deveria ter aprendido antes de se propor a escrever Populações. Os autores que o antecederam, para José Honório “os mestres Varnhagen e Capistrano de Abreu ${ }^{159 ", ~(R o d r i g u e s, ~ 1988: ~ 4), ~ j a ́ ~}$ tinham trabalhado sobre tal assunto. A partir desse "incidente" (Rodrigues, 1988), ele passou a compreender o valor do elemento histórico na formação da "psicologia dos povos". Oliveira Vianna diria que nós todos não somos senão uma coleção de almas, que não nos vêm do infinito do tempo. O jurista fluminense tem uma obra árida, que

\footnotetext{
${ }^{158}$ José Ingenieros nasceu em Palermo, na Itália e a imigração de sua família para a Argentina pode ser explicada pelo fato de seu pai, um professor e periodista italiano, ter se vinculado a Primeira Internacional e dirigido um periódico socialista. Cursou medicina e direito na Universidade de Buenos Aires, desenvolvendo sua atividade política junto ao Partido Socialista Argentino entre 1895 e 18994. Na faculdade de medicina teve, como professor, José Maria Ramos Mejía - responsável por despertar em Ingenieros o interesse pelas ciências naturais, biológicas e sociais, ensinando - lhe as primeiras noções da filosofia cientificista. Dentre suas obras a mais significativa é $O$ Homem medíocre (1953).

${ }^{159} \mathrm{Em}$ análise a respeito da produção intelectual da década de 1930, Carlos Guilherme Mota explica que "O redescobrimento do Brasil pode ser registrado na própria sucessão das produções historiográficas posteriores à Revolução de 1930. A Revolução, se não foi suficientemente longe para romper com as formas de organização social, ao menos abalou as linhas de interpretação da realidade brasileira - já arranhadas pela intelectualidade que emergia em 1922, com a Semana de Arte Moderna, de um lado, e com a fundação do Partido Comunista, de outro. Assim, como no plano da política, na seara historiográfica novos estilos surgiram, contrapondo às explicações autorizadas de Varnhagen, Euclides da Cunha, Capistrano de Abreu e Oliveira Vianna concepções até então praticamente inéditas, e que soariam como revolucionárias para o momento. A Historiografia da elite oligárquica empenhada na valorização dos feitos dos heróis da raça branca, representada pelo Instituto Histórico e Geográfico Brasileiro (fundando em 1838), vai ser contestada de maneira radical por um conjunto de autores que representarão os pontos de partida para o estabelecimento de novos parâmetros no conhecimento do Brasil e de seu passado." (Mota, 2008: 69)
} 
procura investigar na poeira do nosso passado os germes das vidas atuais, cindindo daí os "albores da nossa psique nacional" (Rodrigues, 1988: 6).

Para chegar a essa condição de análise da sociedade brasileira, Oliveira Vianna expõe, já no prefácio de sua obra, quais foram os teóricos que pautaram metodologicamente sua obra. A respeito, o professor Bernardo Ricupero comenta que:

A obra do engenheiro católico francês Pierre Guillaume-Fréderic Le Play e de sua escola sociológica é provavelmente a que deixou a marca mais profunda no seu pensamento. A influência da escola de Le Play se exerce particularmente sobre o método de Oliveira Vianna: a construção de tipos regionais com base em fatos sociais. Os tipos surgiriam do ambiente natural e, a partir daí, do tipo de propriedade e de família neles desenvolvidos. Sinal da importância da escola do engenheiro francês para o autor de Populações meridionais do Brasil: populações rurais no centro-sul estão no próprio título do livro, muito similar ao subtítulo da obra de um discípulo de Lê Play, Edmond Desmolins, Lês français d'aujourd'hui: lês types sociaux du midi e du centre. (...) Também marca Oliveira Vianna a psicologia social de Gustave Le Bon. Esse autor desenvolve a idéia da existência de alma da raça ou caráter nacional. De acordo com Le Bon, as raças distinguiriam não tanto pelas características físicas, mas pelos traços psicológicos, havendo, consequentemente, uma hierarquia entre elas. É por isso que seria possível para 60 mil ingleses dominar 250 milhões de indianos. (Ricupero: 2007: 53).

Oliveira Vianna é contraditório na sua formação teórica. Como intelectual preso a valores científicos e práticos, procurava argumentos para sua tese de que a história explicaria e orientaria o futuro, mas pouco cuidou de entender o peso da história econômica brasileira nesse percurso. Também podemos observar sua análise da filosofia da história, uma disciplina que "aborrece os pragmatistas e que ele nunca igualmente revelou cultivar. Não cita um único filosofo ou pensador da história. Pensador que o instrui é o secundário Le Play” (Rodrigues, 1988: 8).

Segundo José Honório, as afirmações de Oliveira Vianna, identificadas como um aspecto racista ou arianista da sociedade brasileira figuram como uma aproximação à teoria de Gobineau (1816-1882), intelectual que fez carreira diplomática e formulou um pensamento sobre a conduta social e racial, aspectos que se refletem em sua obra etnológica, histórica e de ficção. Ele pertencia à pequena nobreza e era ardentemente legitimista. Seu livro mais célebre e pouco lido, Essai sur I'Inegalitté dês 
Races Humaines, é uma reflexão sobre a decadência da humanidade. Para o historiador carioca, Gobineau considerava a raça o elemento essencial das civilizações, dizia existir uma hierarquia das raças e proclamava a raça ariana como "a única raça civilizadora" (Rodrigues, 1988).

Não é realmente estranho que um mulato brasileiro, de grande leitura, rico no poder do pensamento, além de grande e fluente escritor, tentasse aplicar as ideias de superioridade da raça ariana num país de mestiços, de todas as misturas? Não é surpreendente que Gobineau tivesse exercido tanta influência sobre Oliveira Vianna, principalmente nos seus capítulos sobre raça? (...) O escritor francês exerceu funções diplomáticas aqui (1869-1870) e suas ideias se aplicavam diretamente ao Brasil, que ele tanto desprezava, como se pode ver em D. Pedro II e os Sábios Franceses e em D.Pedro II e o Conde de Gobineau - correspondência inédita, chegando a escrever que todo o círculo palaciano de D.Pedro era composto de mulatos - que ele desprezava - e manifestou sua descrença no futuro do Brasil devido a isso. (Rodrigues, 1988: 8).

A obra de Oliveira Vianna é identificada aqui como fonte de ojeriza e repulsa ao povo brasileiro. Nenhum integrante dos setores subalternos tem qualidades, ou mesmo possibilidades, de fazer parte de grupos mais ativos e participantes das grandes decisões do país. "Melhor fora que tivéssemos outro povo, outra gente, branca, ariana, educada, alfabetizada, senão culta" (Rodrigues, 1988: 16). O conhecimento geral da obra se refere à exortação da família patriarcal e a sua obra para efetivar a construção da sociedade brasileira. Segundo o próprio Oliveira Vianna:

A expansão pastoril, expansão agrícola, expansão mineradora e, por fim, emersão, no IV século do latifúndio cafeeiro nos planaltos - tudo isto acaba por fazer prevalecer, uma nossa sociedade meridional, sobre o tipo peninsular e europeu do "homem urbano" ou do colono "semi-urbano", o tipo especificamente nacional do "homem do campo", cujo supremo representante é - o fazendeiro. (...) Este possante senhor de latifúndios e escravos, obscurecido longamente, como acabamos de ver, no interior dos sertões, entregue aos seus pacíficos labores agrícolas e à vida estreita das nossas pequenas municipalidades coloniais - somente depois da transmigração da família imperial, ou melhor, somente depois da independência nacional, desce das suas solidões rurais, para, expulso o luso dominador, dirigir o país. (Vianna: 1952: 49). 
Essa aversão ganha maior intensidade quando José Honório passa a dedicar-se, ao longo dos capítulos de seu livro, às obras mais polêmicas e, ao mesmo tempo, consistentes de Oliveira Vianna. Exemplo disso é a leitura sobre Populações meridionais do Brasil $^{160}$.

A crítica sumária exposta em História da história do Brasil é que o livro não passa de uma mera "exaltação da nobreza territorial brasileira" (Rodrigues, 1988). Para defender tal posição, José Honório não deixa de identificar e enumerar as formas conceituais que Oliveira Vianna destaca quanto à participação decisiva da nobreza rural para explicar a formação social do país. Os desarranjos da sociedade eram resultados da impossibilidade da "nobreza territorial" permanecer no controle do Estado e ter papel decisivo no arranjo política em que transitávamos.

Em seu livro tenta dar à classe rural a riqueza principal, valoriza a burguesia comercial e mostra seu desprezo pela plebe rural ou urbana e o papel que lhe cabe. Ele reconhece a função de cada classe, embora demonstre sempre um profundo desdém pela plebe. Chega mesmo a usar, nesse primeiro livro, também da expressão peão, com conotação restrita ao Sul. (...) Afirma ainda que a luta entre partidários da liberdade nacional se dera entre burgueses e rurais, ou entre uma nobreza urbana lusitana e outra, influente e prestigiosa, a dos fidalgos e parasitas lusos fugidos do exército de Junot. As três classes buscam a preponderar e essa luta se prolonga até depois da Abdicação, só cessando com a morte de D. Pedro I em 1834 e a consequente extinção do partido recolonizador, representado na Sociedade Militar, onde predominam os portugueses. (Rodrigues, 1988: 20).

Essa passagem e o próprio livro Populações meridionais são muito esclarecedores, pois contemplam a noção que a luta de classes é travada entre os representantes da elite portuguesa, a qual, por sua vez, se encastela no poder e não permite que qualquer outro segmento social possa fazer parte dessa lógica de dominação.

\footnotetext{
160 A respeito de Populações Meridionais no Brasil, o professor Bernardo Ricupero afirma que: "A principal motivação de Oliveira Vianna ao longo de sua obra é, como afirma no Prefácio de seu livro, "ressaltar o quanto somos distintos de outros povos." Esse programa de pesquisa se imporia já que, apesar de a comparação das novas sociedades americanas com as antigas sociedades européias evidenciar a diferença entre as duas, nossas classes dirigentes revelariam verdadeira obstinação de não conhecerem a originalidade das suas condições. A consequência dessa postura se sentiria na cópia por parte das novas nacionalidades dos exemplos fornecidos pelas civilizações ocidentais mais antigas." (Ricupero, 2007: 56).
} 
Antes de continuarmos com as reflexões a respeito do capítulo em que José Honório põe à prova "Populações", cabe uma reflexão a respeito das condições de escrita e reflexão de Oliveira Vianna.

$\mathrm{O}$ autor procura destacar as características dos bandeirantes, a generalização do meio pastoril, a descoberta e utilização dos campos rio-grandenses e platinos, a contribuição do meio geográfico, os rios utilizados pelos aventureiros paulistas como verdadeiras estradas duplas, a capacidade de expansão e mobilidade migratória, a exploração da terra, a poligamia, a fecundidade das mulheres como grandes fatores para o aumento da população brasileira. José Honório aponta na obra de Oliveira Vianna que:

Fala bem dessa expansão paulista e de seus três focos de irradiação: Itu, Sorocaba e Taubaté. Deles partem as correntes para o Sul, "silenciosa, tranqüila, obscura, sem heroicidade deslumbrante, mas não menos bela na sua marcha e nos seus efeitos". Nesta corrente Oliveira Vianna louva o que fizeram os paulistas "que em dois séculos dispersaram-se por quase todo o Brasil" e considera maravilhosa a amplitude de suas zonas de fixação, o que não surpreende, pois muitos antes dele exaltaram a obra bandeirante. Ao entrar no capítulo sobre a etnologia das classes rurais, volta de novo aos seus preconceitos raciais, dignos da subciência que cultivava, e indignos dos bandeirantes e do povo brasileiro. (Rodrigues, 1988:27).

O historiador carioca coloca-se contra a insistência de Oliveira Vianna em identificar os tipos que tiveram participação ativa na constituição das características políticas e sociais do povo brasileiro. Para isso, insiste José Honório, é fundamental destacar que os grupos que compunham essa sociedade não eram exclusivamente "mestiços, foros ou degradados" (Rodrigues, 1988). As bandeiras exemplificam a simbiose entre esses elementos e os futuros proprietários agrícolas ou "fundadores de currais". (Rodrigues, 1988).

Embora fosse um crítico do estrangeirismo no pensamento nacional, Oliveira Vianna não escapou das ideias e modelos que tinham uma circulação razoável entre nossa intelectualidade naquele momento. A sua formação, principalmente entre os séculos XIX e XX, constitui-se debaixo de forte influência de nomes europeus, majoritariamente franceses. A historiografia brasileira, por sua vez, ainda seguia as velhas orientações historicistas de meados do século XIX: 
Inspiradas na busca da identidade nacional, seguia as sugestões de Karl Friedrich Von Martius em Como escrever a História do Brasil (1840) e da monumental História geral do Brasil, de Francisco Adolfo Varnhagem (18541857). Esses autores definiam a base do ensino de história no país de passagem do século, não obstante as inovações de perspectiva de Capistrano de Abreu (1853-1927), com os Capítulos de história colonial (1907), buscassem estimular um melhor conhecimento da formação do interior do país. De conjunto, era uma historiografia pobre na interpretação das forças sociais, econômicas e culturais que moviam a história oficial, concentrada em grandes personalidades e acontecimentos. (Weffort, 2006: 254).

Considerar a obra de Oliveira Vianna como racista recupera somente aspectos da condição inovadora que ela representa. No entanto, para a compreensão da realidade brasileira naquele momento, essa posição não diz respeito aos interesses de José Honório Rodrigues. Sua postura como leitor crítico de Oliveira Vianna recorre a uma interpretação das condições em que o processo de conformação do pensamento racial e autoritário ganhou maior visibilidade. Além dos traços racistas, a adulação à "nobreza rural" (Rodrigues, 1988) consolida uma visão contrária e desrespeitosa às classes inferiores.

Nos louvores à nobreza rural, respeito à palavra dada, sentimento de probidade, respeitabilidade, decoro pessoal, ele usa uma linguagem fluente e concisa, revelando ser um grande senhor da língua; mas sempre desrespeita as classes "inferiores", a plebe, como chama, filha da mestiçagem, que ele abomina. Capadócios, moleques, são os apelidos que dá aos grupos mais modestos da sociedade, e seria lastimável se alguém construísse o caráter nacional brasileiro tendo como base as preconceituações de Oliveira Vianna, racista emperdenido, arianista, antinegro, mais que antiíndio, mas, sobretudo considerando inferior tudo o que não é branco, ariano. (...) Para ele todos os grandes atributos independência, hombridade, altivez discreta e digna - vêm da herança de sangue ariano e do regime de latifúndio. Não pode fazer nada de mais reacionário que julgar que os melhores são os brancos arianos e proprietários de grandes latifúndios. Estes se habituam a exercer um poder considerável sobre uma massa de homens, e assim, é e deve ser, achava Oliveira Vianna. (Rodrigues, 1988: 23). 
Outra particularidade da obra de Vianna que José Honório recupera está relacionada à sua forma de exaltar a obra paulista dos bandeirantes. É através da análise desse movimento que existe uma identificação entre a missão de ocupar o território e os interesses da oligarquia proprietária de terras na ponta desses "projetos".

Os grandes domínios rurais dão às bandeiras o seu primeiro e principal elemento: os chefes. Esses grandes potentados territoriais trazem nas veias uma forte herança de bravura, de intrepidez, de audácia; são todas personalidades fortemente vincadas. Os primitivos colonizadores lusos, de quem descendem, representam a porção mais eugênica da massa peninsular; porque, por uma lei de antropologia social, só emigram os caracteres fortes, ricos de coragem, imaginação vontade. Na sua espantosa energia e fortaleza moral, os caudilhos bandeirantes bem revelam quão poderosas foram essas reservas de eugenismo acumuladas nos primeiros séculos. Uma das primeiras razões para o concessão de sesmarias é, aliás, ter batido o índio, ou penetrado o sertão, ou lutado com o flibusteiro normando ou neerlandês. Como na idade média, a seleção se faz, na sociedade colonial do II e III séculos, pela bravura, pelo valor - pela "virtude", no sentido romano da expressão.(Vianna, 1952: 115).

O povo, na obra de Oliveira Vianna, não apresenta condições de constituir-se como "massa homogênera" por meio de sua propalada unidade de raça, da civilização e da língua, entre outros elementos que fica difícil saber "o que mais é superficial e insuficiente para explicá-lo ao País" (Rodrigues, 1988: 25). Ao contrário desse princípio, será necessário levar em conta a diversidade dos habitats e sua ação durante três ou quatro séculos. Segundo o professor Gildo Marçal Brandão:

As variações regionais do caldeamento dos elementos étnicos e, principalmente, a inegável diferença das pressões históricas e sociais sobre a massa nacional, quando exercida ao norte, ao centro e ao sul. Atentando sobretudo para fatores geográficos, históricos e sociais, será possível perceber que a sociedade brasileira é, na verdade, uma estrutura descontínua e ganglionar, um quebra-cabeças incompleto, com partes contrastantes e desconexas entre si. Na verdade, em vez de um país, estamos diante três regiões (a do norte, e do centro-sul e a do extremo-sul) cuja colonização gerou três sociedades (a dos sertões, a das matas e a dos pampas) e três tipos sociais distintos (o sertanejo, o matuto e o gaúcho). (...) Todos esses tipos são rurais, porquanto os urbanos não passam de, segundo Vianna, "reflexos ou variantes do meio rural a que pertencem”. (Brandão, 2007: 78). 
Se o período de análise for o colonial, a obra de Vianna enfatiza o papel dos estadistas coloniais, alegando que estes sempre souberam preservar os interesses da coroa portuguesa, além de trazer à tona as condições atípicas com as quais se deparavam na colônia. Tendo como meta a preservação da unidade colonial, "sempre souberam sacrificá-la toda vez que o interesse maior do governo português assim o determinava" (Odalia, 1997: 143). Destarte, concordando com a ideia de Varnhagen, via a construção do Estado e da Nação a partir da participação ativa da coroa na colônia, encontrava aí um grande adepto. A teorização de Oliveira Vianna defendia a existência de uma monarquia de sentido católico tradicional ibérico, na qual se preserva o princípio do Estado diretor, a tradição histórica do poder monárquico português e as liberdades das camadas dirigentes e das comunidades organizadas.

Com relação ao que vem a ser uma Nação, o pensamento de Oliveira Vianna ganha uma conotação bem específica, pois remete à iniciativa de mostrar os limites da Nação brasileira devido a sua composição por vários elementos étnicos. Tal peculiaridade seria o elemento determinante dos limites que uma sociedade miscigenada poderia oferecer a História Mundial. A possibilidade de superação dessa ordem estaria claramente limitada, pois não poderíamos contar com a formação de uma sociedade autônoma e fadada ao progresso. Todavia, nem tudo estaria perdido, haja vista que se fôssemos conduzidos pela elite proprietária de terras, passaria a existir uma real possibilidade de esse grupo social ser capaz de colocar o Brasil no caminho do progresso.

Cabe ressaltar que a obra de Oliveira Vianna, em certo sentido, tem uma aproximação com a produção de Capistrano de Abreu, pois ambos recuperam, para dar conta de suas referências e interesses, o cientificismo do século XIX, uma vez que tomam como referencial o positivismo. Da produção de Vianna, fica evidente que a sua noção de história era mais moderna do que sugere esse positivismo estreito, visto, por exemplo, que insistiu mais de uma vez que teorias e hipóteses eram indispensáveis ao conhecimento histórico. $\mathrm{Na}$ introdução de Populações Meridionais fica explícita a contribuição do historiador a várias áreas do conhecimento: a antropogeografia, a antropossociologia, a psicologia coletiva e a ciência social. Segundo o jurista fluminense:

Para a perfeita compreensão do passado, a investigação científica arma hoje os estudiosos com um sistema de métodos e uma variedade de instrumentos, que 
lhes dão meios para obterem dele uma reconstituição, tanto quanto possível, rigorosa e exata. No estado atual da ciência histórica, o texto dos documentos não basta só por si para permitir reviver uma época ou compreender a evolução particular de um dado agregado humano. É preciso que várias ciências, auxiliares da exegese histórica, completem com os seus dados as insuficiências ou obscuridades dos textos documentários ou expliquem pelo mecanismo das suas leis poderosas aquilo que estes não podem fixar nas suas páginas mortas. O culto do documento escrito, o fetichismo literalista é hoje corrigido nos seus inconvenientes e nas suas insuficiências pela contribuição que à filosofia da história trazem as ciências da natureza e as ciências da sociedade. (Vianna, 1952: 12).

Dessa forma, o pensamento ultraconservador, como o designou José Honório Rodrigues, repercute até hoje entre os notórios "intérpretes do Brasil". A leitura do jurista fluminense sobre a formação brasileira identifica o liberalismo como algo exótico em autores que procuram interpretar a sociedade a partir como apta a lógica do sistema política liberal. A crítica à inoperância de uma tradição que macula a ordem republicana, tendo o jurista fluminense como expoente da maior cepa dos "autoritários", possui uma ideia de Nação e sociedade incompatíveis com os preceitos daqueles que, como José Honório, vislumbra o funcionamento da ordem liberal nacionalista entre nós.

O que nos parece de grande importância para a definição do nacionalismo em José Honório Rodrigues, além desse contexto social em que "projeto nacionalista" estaria vinculado diretamente à organização do poder político e a sua estratégia de elaboração, é que sua crítica a Vianna destaca a tentativa de entendimento de colocar em prática um nacionalismo-liberal que criasse, diferente do que acreditava Oliveira Vianna, uma integração dos vários grupos étnicos que compõe a sociedade e, além disso, possibilitando a todos que pudessem participar nas decisões com as funções institucionais atendendo suas reivindicações.

Para José Honório, pensar o Brasil seria entender como colocaríamos em funcionamento essa base, ou seja, uma sociedade que atendesse as necessidades do povo. Um Capistrano de Abreu oferece a possibilidade de mostrar o quanto, só é possível a compreensão histórica. 


\section{4 - Crítica ao pensamento tradicionalista: Francisco Iglésias, um seguidor de José}

\section{Honório Rodrigues}

Neste subitem pretendemos destacar a produção de um intelectual que, ao nosso entendimento, por aproximar-se a José Honório Rodrigues que apresenta, em sua obra, uma preocupação de caráter nacionalista.. Aspecto que o aproxima, ao nosso ver, ao legado de José Honório Rodrigues.

Com o intuito de destacar a importância do intelectual mineiro, segue os comentários de seu ex-aluno, o historiador José Murilo de Carvalho:

A natureza de seu trabalho acadêmico é coerente com os traços gerais de sua atuação política. Iglésias, a meu ver, é antes de tudo um ensaísta e um crítico de história. À exceção de sua tese de livre-docência, de caráter monográfico, quase toda a sua produção é confessadamente o pai do ensaismo, Montaigne, certamente reforçada pela leitura dos autores que marcaram sua geração, como Ortega y Gasset, Unamuno, Malraux. (...) O melhor de sua ensaística está no livro História e Ideologia, publicado em 1971. (Carvalho, 2005: 386).

O fulcro da obra de Francisco Iglésias é a produção e a missão do historiador, além das considerações sobre a preocupação legítima que deve ter em relação a temas amplos e gerais que estão prementes na sociedade. Na procura por “ideologias motivadoras" (Iglésias: 1971: 10), o historiador tem um compromisso intelectual dos mais significativos na sociedade brasileira.

A contribuição de Francisco Iglésias à história das ideias remete a textos escritos em momentos diferentes: "Estudo sobre o pensamento reacionário: Jackson de Figueiredo" e "Celso Furtado: pensamento e ação", que fazem parte da coletânea "História e Ideologia" (1971). ${ }^{161}$

O estudo do legado intelectual de Jackson Figueiredo é fruto do interesse de Francisco Iglésias pela produção no campo do pensamento social brasileiro. Desse modo, a escolha pelo pensador sergipano ocorre por se tratar de uma personalidade expressiva quanto à influência no pensamento católico conservador, aspecto que ganha

$161 \mathrm{O}$ ensaio Estudo sobre o pensamento reacionário: Jackson de Figueiredo foi originalmente publicado em 1962, na Revista Brasileira de Ciências Sociais de Belo Horizonte, MG. Já o ensaio Celso Furtado: pensamento e ação apareceu primeiro como prefácio à edição de Formação econômica do Brasil,_da Universidade de Brasília (Biblioteca básica brasileira). 
terreno nos anos de 1920 e $1930^{162}$. Figueiredo é o criador do Centro Dom Vital e o conjunto de sua obra, elaborada em curto tempo de vida, é expressão de parte considerável do pensamento católico dos primeiros trinta anos do século XX. Em sua produção está expressa parte considerável do pensamento reacionário, que nos anos 20 teve, por meio do então célebre escritor, significativa responsabilidade por sua expansão na sociedade brasileira.

Jackson de Figueiredo insurge-se contra as correntes políticas de seu tempo. Homem de sensibilidade para o ambiente, pronto a entender, colaborar, a denunciar e a reagir, é natural que viva plenamente os problemas do Brasil, sobretudo em seus últimos anos, que são os da movimentada década de 20. As posições que assume, em defesa da ordem, fazem dele batalhador semelhante aos que se encontram nos países europeus: pela ordem e pela tradição, contra o que consideram a calamidade revolucionária, que pressentem em tudo, no liberalismo ou no socialismo, com as diversas colorações que tais correntes apresentam. (Iglésias, 1971: 111).

Na obra de Jackson de Figueiredo é identificada uma aproximação a valores típicos do tradicionalismo que, seguindo os princípios do pensamento conservador, ignora a existência de um processo capaz de levar à necessária e contínua mudança social. Busca-se ver a realidade de maneira idílica e ideal, de tal forma que não necessite sofrer nenhuma alteração, o que nega a possibilidade de questionamentos ou modificações da ordem social. Sua missão, como expoente de uma tradição intelectual, é combater, quando necessário, aqueles que se opõem ao "curso tradicional dos fatos" (Iglésias, 1971), para o grupo de pensadores a qual pertence é absurda a pretensão de igualdade. Para eles, os homens são naturalmente desiguais, existindo uma hierarquia, com diferentes atribuições a cada um. Na sociedade haveria os que mandam e os que obedecem.

Esse pensamento tradicionalista-conservador é embasado por uma ideologia que expressa os valores e determinações da ordem conservadora ${ }^{163}$. À medida

\footnotetext{
${ }^{162}$ No prefácio do brilhante estudo de Lafetá (2000), Antonio Candido expõe as relações que formaram um grupo de intelectuais ligados ao pensamento católico: "O estudo do decênio de 1930 valeu como caso ideal para o desígnio de Lafetá, pois assim como o Modernismo estava segundo ele transitando do "projeto estético" para o "projeto ideológico", o mesmo se dava com a concepção de literatura em Alceu Amoroso Lima, que a partir de 1929 deixou de ser um intelectual disponível para tornar-se próximo a Jackson de Figueiredo, tornando-se um católico ardente e empenhado," (Candido, 2000: 11).

${ }^{163}$ O professor Francisco Iglésias aponta que os representantes mais expressivos dessa ideologia, da qual Jackson de Figueiredo é um de seus adeptos no Brasil, são: Henri Massis, Auguste Viatte, Charles
} 
que o mundo atual foge dos seus interesses, tem a meta de procurar a volta ao passado, configurando assim seu reacionarismo. "O tradicionalismo é romântico e falso; na suposição de uma verdade eterna, imutável, é anti-histórico, pois desconhece o fluxo, que é a própria essência da história." (Iglésias, 1971: 113).

Para o pensamento social, político e historiográfico, a influência de conceituações estrangeiras e mesmo, em grau semelhante, de autores estrangeiros, é fruto de uma dependência, de uma falta de autonomia para interpretar a realidade. A grande influência de autores estrangeiros que atuaram no país, "com moderação ou fanatismo" (Iglésias, 1971: 126), marca o aparecimento de linhagens/famílias de pensamento, cuja continuidade deu-se de forma linear. Cabe destacar que a linhagem/família citada pela grande maioria dos intelectuais daquele período tem no liberalismo e nas suas especificidades no contexto brasileiro a linha mestra de sua produção intelectual.

O positivismo para Teixeira Mendes, o evolucionismo para Sílvio Romero, o liberalismo para Rui Barbosa - não foi por simples gosto da novidade que tais autores abraçaram essas doutrinas: elas traduziam o seu modo de ser, representavam para eles a inteligência perfeita do universo. Mais ainda: viram nelas a possibilidade de adequação ao Brasil e de sintonia do Brasil com o que havia de novo no mundo. Pretenderam, pois, através delas, colocar o país no primeiro plano, fazendo-o participar da vida de seu tempo, como nação civilizada, livre dos preconceitos que consideravam obsoletos, ao mesmo passo que, com elas, pretendiam dar solução aos seus problemas. A estrutura arcaica e o pensamento antigo que informava a sociedade seriam os responsáveis pelas mazelas nacionais. Não se veja em tais manifestações, portanto, a simples cópia, transposição de ideologias alienígenas pelo gosto da novidade, sem consonância com o país real. (Iglésias, 1971: 127).

A condição de país periférico explica em boa medida a debilidade da inteligência nacional ${ }^{164} \mathrm{e}$ suas limitações quanto à conceituação plausível para o

Maurras, Afonso Sardinha - teórico do Integralismo Lusitano -, Joseph Maistre e Louis Veuillot. (Iglésias, 1971).

164 É amplamente conhecida a argumentação de Antonio Candido quanto à especificidade de nossa produção literária: "Há literaturas de que um homem não precisa sair para receber cultura e enriquecer a sensibilidade; outras, que só podem ocupar uma parte da sua vida de leitor, sob pena de lhe restringirem irremediavelmente o horizonte. Assim, podemos imaginar um francês, um italiano, um inglês, um alemão, mesmo um russo e um espanhol, que só conheçam os autores de sua terra e, não obstante, encontrem neles o suficiente para elaborar a visão das coisas, experimentando as mais altas emoções literárias. Se isso já é impensável no caso de um português, o que se dirá de um brasileiro? A nossa literatura é galho 
entendimento de nossa realidade. Essa debilidade vem das condições de grande marginalização, imperantes ao longo do Império e reproduzidas nos primeiros vinte anos da República, já que permanecia a dependência em relação ao exterior e o país estava sujeito aos centros de dominação em cujo sistema econômico se integrava ${ }^{165}$. Dessa forma, o Brasil em que Jackson Figueiredo tem sua atuação e militância é um país que está em pleno processo de mudança, graças às condições imperantes pela eclosão da $1^{\mathrm{a}}$ Grande Guerra Mundial (1914-1918). No campo político, encontramos a prática de um continuísmo, sofrendo somente os pequenos e "quase inexpressivos" embates pela disputa do poder local. (Iglésias, 1971: 129)

Outro aspecto a ser destacado do cenário político-social que se configura no país durante os primeiros anos da República refere-se à instituição que havia sido um dos pilares da Monarquia, mas que tem sua condição alterada na nova organização política do país, isto é, a Igreja Católica. Instituição que sofre significativa perda quanto ao papel de partícipe nos rumos tomados pela sociedade brasileira.

A Igreja é tão acomodatícia que não faz ouvir sua palavra na direção do país; integra-se no processo como as outras forças, equilibrando-se na troca de apoios e favores. País de tradição cristã, formado pelo catolicismo, recebeu por herança o colonialismo do Concílio de Trento, suavizado pela atitude da gente portuguesa e institucionalizado no regime legalista, em que o poder espiritual fica submetido ao poder civil. Trata-se, portanto de religião em que a parte formal é muito importante, mas que tem de ser modificada em função da distância dos centros diretores e da frouxidão explicável pela falta de assistência. A extensão da terra, o isolamento dos núcleos populacionais, tudo leva a uma falta de coesão que se traduz na hipertrofia do poder privado e na

secundário da portuguesa, por sua vez arbusto de segunda ordem no jardim das Musas...Os que se nutrem apenas delas são reconhecíveis à primeira vista, mesmo quando eruditos e inteligentes, pelo gosto provinciano e falta do senso pode levar ao desinteresse e até menoscabo das nossas. (...) Comparada às grandes, a nossa literatura é pobre e fraca. Mas é ela, não outra, que nos exprime. Se não for amada, não revelará a sua mensagem; e se não a amarmos, ninguém o fará por nós. Se não lermos as obras que a compõem, ninguém as tomará do esquecimento, descaso ou incompreensão. (Cândido, 2007: 12). Premissa utilizada por Gildo Marçal Brandão, que disse: “(...) De fato, quando imaginava qual poderia ser um comentário consistente a 'por que pensar o Brasil', o primeiro argumento que me veio a mente foi por que se não fizermos ninguém o fará.” (Brandão, 2007: 140).

165 As condições da economia brasileira no período que justificam as afirmações de Iglésias estão pautadas, em grande medida, na análise feita por Celso Furtado em Formação econômica do Brasil, obra sobre a qual o professor Francisco de Oliveira apregoa: "Teoricamente, Formação econômica do Brasil, é uma leitura keynesiana da história brasileira. O ecletismo cepalino também aí está presente, mas a marca forte é keynesiana. Incorporando contribuições de variada precedência, o forte do livro é a explicação que apresenta da transição da economia exportadora de café para a economia industrial que emerge a partir da $2^{\mathrm{a}}$ Guerra Mundial. Um engenhoso esquema keynesiano explica como, queimando café, o governo brasileiro, sob Vargas, mantinha os níveis de renda interna e, ao mantê-los, preparava a transição para a industrialização." (Oliveira, 2003: 19). 
atrofia do poder público, no desenvolvimento do particularismo e na fragilidade da vida política, como tem sido assinalado pelos estudiosos da história e da sociologia, assim sendo, se a Igreja desempenha papel significativo através das ordens, das irmandades e dois padres em geral, não é papel que tenha força bastante para marcar a sociedade; a fé é quase frouxa, não configura a vida com traços cristãos, satisfazendo-se em exterioridades e convenções, sem a vivência do conteúdo. (Iglésias, 1971: 131).

A intelectualidade ligada à Igreja nos anos 20 do século passado começa a organizar-se, como indica, por exemplo, a criação da revista A Ordem e o Centro Dom Vital (entre os anos de 1921 e 1922). ${ }^{166}$ Integrado na Igreja Católica desde 1918, Jackson de Figueiredo tem seu pensamento social e político profundamente marcado por sua trajetória junto a líderes católicos. A fase de fundação da revista e do centro D. Vital é a de maior produção e expressão que o autor irá alcançar ${ }^{167}$. A causa abraçada o catolicismo - é algo vivo que não se resume única e exclusivamente à fé ou à doutrina. É primordialmente uma atitude diante de tudo, uma forma de compreensão da realidade. O chão social que ancora seu pensamento é a manutenção da ordem, a defesa intransigente da autoridade, da religião. Iglésias analisa de forma minuciosa a condição do pensamento de Jackson de Figueiredo nesse contexto:

166 Segundo um importante estudo sobre a obra de Figueiredo: “A plataforma política de Jackson de Figueiredo consiste então em organizar essa elite espiritual que deveria por direito (teo)lógico conduzir a vida nacional. Sua tarefa é expressamente a de criar instituições que formem, a partir do culto da ordem (e da hierarquia e autoridade, seus correlatos), novos quadros capazes de intervir, em nome do catolicismo e em consonância estrita com as diretrizes da Igreja, em todas as dimensões da realidade brasileira. É sintomático que o ateu que professara como única religião a amizade refira-se agora a seu grupo como "minha pequena Igreja", comunidade ecumênica de homens livres para submeter-se à ordem que irradia o mesmo imperativo de submissão em todas as direções. Tal intento se desdobra concretamente na fundação da revista $A$ Ordem em 1921 e do Centro Dom Vital no ano seguinte, instâncias de preparo e divulgação da prédica, de cujo núcleo emergem as ações políticas consideradas mais urgentes a cada momento para aproximar a organização real da sociedade da ordem perdida, de que só se encontra um equivalente histórico numa visão idealizada da tradição brasileira que dá toda ênfase ao papel da religião católica como constitutiva da unidade nacional. As teses de Jackson seguem de perto o pensamento conservador anti-revolucionário europeu que ganha impulso no século XIX (Joseph de Maistre é talvez o autor mais citado por ele) e estará em consonância com os movimentos políticos mais à direita nas primeiras décadas do XX, que reagem contra tudo que for "revolucionário", ou seja, contra a configuração social moderna que destruiu a harmonia perdida. Restaurar a ordem significa então repor a diferença (e a desigualdade) natural entre os homens, o que redunda no reforço das idéias diretrizes de autoridade e hierarquia, evocação de uma nostalgia medievalista não explicitada, mas que alimenta o imaginário social de insumos como o valor da família, da nobreza cavalheiresca, da pequena propriedade, dos ritmos não urbanos de vida, e de uma vida em comunidade". In: Pinheiro Filho, F. A. A invenção da ordem: intelectuais católicos no Brasil, Tempo soc. vol.19 no.1 São Paulo June 2007.

167 Jackson de Figueiredo nasceu em 1891, na cidade de Aracajú, e morreu afogado na Barra da Tijuca, prematuramente, em 4 de novembro de 1928. 
Com o levante militar do Forte de Copacabana entra em cena o tenentismo. Os jovens militares insurgem-se contra as práticas políticas, mas em outra perspectiva, que se poderia chamar de revolucionária, em comparação com a do escritor católico; são contra o antigo estado de coisas, a dominação tradicional das oligarquias, que se mantêm pela corrupção e pela força. Daí o levante dos 18 do Forte, fraco em número e sem possibilidades de êxito, mas que valeu como protesto, quase bravata. Nesse combate de militares que tem o aplauso de políticos inimigos do candidato que o jornalista Jackson de Figueiredo apoia, vê ele apenas o demagogismo e a anarquia, como consta de seus escritos de $1921 \mathrm{e}$ 1922, enfeixados no volume A Reação do Bom Senso. O levante romântico deflagraria a insatisfação, continuada pelo movimento de 1924 em São Paulo e pela Coluna Prestes. Jackson de Figueiredo vê no caso apenas o desrespeito à autoridade, o incitamento à desordem. Para ele, o militar revolucionário é fruto do positivismo que dominou a Escola Militar e altos setores do Exército. Causalhe indignação esse movimento rebelde de parte de quem devia cuidar da ordem. (Iglésias, 1971: 138).

A preocupação quanto a privilégios políticos não foi o único mote do pensamento de Jackson de Figueiredo. Sua ação estava pautada pelo condicionamento de uma visão da realidade brasileira em que a manutenção da ordem e dos valores mais íntegros da sociedade seria mantida pelo caráter moral da Igreja Católica. Essa premissa caracteriza e atravessa boa parte de sua obra, , revelando o nítido o domínio e a defesa intransigente da fé, uma vez que "para ele tudo que é belo na cultura ocidental resulta da religião católica” (Iglésias, 1971: 146)..

Tudo que não coaduna com os valores católicos é condenado de forma veemente por Jackson Figueiredo. "Liberalismo, socialismo, cientificismo - são alguns dos equívocos em que o mundo de hoje, por haver abandonado o sistema rígido e harmonioso que se desenvolveu pela aceitação da fé, tomando como referência na tentativa de entendimento do Brasil" (Iglésias, 1971).

Outro aspecto que ganha destaque na obra do pensador católico, segundo a análise de Francisco Iglésias, é o nacionalismo. O pensador sergipano acredita na existência de um conjunto de dogmas nacionais, resultado direto da consciência nacional. Não é nosso objetivo investigar este ponto particular, porém, seguindo o intuito deste subitem, a preocupação que ainda transparece centra-se em compreender a análise realizada por Francisco Iglésias quanto à constituição de um pensamento social 
brasileiro, e a possibilidade de identificação do foco central de sua análise que propicia uma interpretação deste pensamento social e sua matização ideológica, que acreditamos estar ancorada no nacionalismo-liberal, pois sua crítica ao pensamento católica de Jackson de Figueiredo ocorre por conta da concepção tradicionalista da história sem pautar-se em preocupação com os interesses que integrariam o povo na sociedade de classes.

Acreditamos que Francisco Iglésias identificou como esses pensadores expoentes do pensamento católica - compreendiam a relação Sociedade-Estado, isto é, estavam pautados por um nacionalismo difuso, porém resultante da militância católica. Candido Mendes, por exemplo, fornece indícios do tipo de nacionalismo defendido por tais intelectuais:

O nacionalismo apresenta característica original: o de ter sido acompanhado de sensível acelaração nos últimos anos da tomada da consciência de seus beneficiários quanto aos rumos do processo e as perspectivas novas que abria à coletividade brasileira. (...) Esta circunstância qualifica especialmente o comportamento das novas gerações católicas engajadas. Não se encontra em nenhuma outra área periférica um avanço tão grande de imperativo da conscientização. Partindo de preocupações reais, o essencial no imperativo de conscientizar-se reside no intuito de se eliminar todo o condicionamento necessitante pelo jogo das forças econômicas e sociais levantadas pelo desenvolvimento. Dessa forma, (...) o povo como que cauciona as ricas articulações de consciência que dariam lugar, ulteriormente, aos comportamentos ideológicos no campo, já, de uma economia integrada. Deita luz sobre a contradição entre o Velho e o Novo Regime, criando o horizonte para uma opção primeira, em função da qual se atingiria ao limiar de uma efetiva autodeterminação para a coletividade semicolonial. (Mendes, 1966: 175).

O princípio que constitui o núcleo da obra de Jackson de Figueiredo ganha contorno definitivo na articulação que Iglésias faz de seu legado intelectual, seja através da preocupação com o peso que o cristianismo tem, seja pelo caráter tipicamente nacionalista de seu pensamento, dessa forma, os dois aspectos realçam o lado conservador dessa interpretação.

Além da tematização do liberalismo nacionalista, o que nos parece melhor caracterizar a aproximação já mencionada entre José Honório Rodrigues e 
Francisco Iglésias é uma tradição que desemboca na análise do pensamento autoritário. O estudo de Iglésias sobre a obra de Oliveira Vianna passa a ter um interesse substantivo, pois existe uma similitude na avaliação que os dois historiadores fizeram acerca do intelectual fluminense.

A análise que Iglésias faz de Oliveira Vianna é extremamente crítica, pois não se omite em mostrar que no centro de suas ideias há uma concepção eivada de preconceitos sobre a constituição racial do povo brasileiro, o que agrava as posições conservadoras do mestre. Nele, o nacionalismo e a preferência pela centralização política se ligam a um autoritarismo baseado essencialmente na falsa convicção de que a nossa sociedade se formou sob a liderança de "elites arianas" (Iglésias, 2009) de caráter aristocrático, ilusão que o historiador mineiro explicita. Exemplo disso seria a problematização, por parte de Iglésias, acerca da obra O Occaso do Império:

Em O Occaso do Império, 1925, temos o primeiro texto historiográfico de Oliveira Vianna, embora em $O$ Idealismo na evolução do Império e da República, 1922, já fosse historiografia, sem ser um livro. Evolução do povo brasileiro, 1923, por sua vez tem muito de historiografia, embora fosse visto como de sociologia. O Ocaso do Império é tipicamente historiográfico. Oferecendo grandes contribuições a respeito da discussão do cenário monárquico, sendo o primeiro estudo importante da crise da monarquia, que culmina com a sua queda, em 1889, pouco mais de vinte anos depois. Tudo é mostrado neste livro sóbrio, nada retórico - distante dos arroubos de Populações, por exemplo -, até de vocabulário menos frondoso. É uma obra singular na bibliografia de Oliveira Vianna, cheia de arroubos e tematizações que pouco ofereciam de concreto. (Iglésias, 2009: 63).

Com os festejos do centenário do nascimento de D. Pedro II, o Instituto Histórico Geográfico Brasileiro (IHGB), que tinha o ex-imperador como patrono, incumbe Oliveira Vianna da tarefa de publicar um ensaio para a comemoração do evento. Aceitando a tarefa, o intelectual fluminense logo percebe que não poderia ficar restrito ao período que fora anteriormente designado a ele, isto é, 1887 a 1889. Assim, recua no tempo a fim de elaborar um estudo consistente a respeito dos anos que correspondem desde a "evolução do ideal monárquico parlamentar" até a "queda do império". Sempre atento à temática, inicia a tarefa de desvendar os vários itens que compõe o livro e, em grande medida, atinge seus objetivos de forma satisfatória. Não 
procura reconstituir literalmente o acontecido, mas sim captar o pensamento que o dirige. Já no prefácio, aponta os interesses quanto ao enfoque historiográfico do livro:

Há duas espécies de história - disse um dos nossos grandes espíritos: a história dos fatos e a história das ideias. Por isso mesmo há duas espécies de historiadores: os que historiam fatos e os que historiam ideias. Neste livro, eu procuro, de preferência, historiar ideias. Daí a escassez dos dados biográficos e dos dados cronológicos neste ensaio, em que tento descrever a evolução da mentalidade das nossas elites no momento justo em que passam da grande ilusão monárquica para a grande ilusão republicana. $\mathrm{O}$ meu objetivo nesse volume é, por isso, definir, de uma maneira precisa, o papel exercido na queda da monarquia pela idéia liberal, pela abolicionista, pela ideia federativa, pela ideia republicana e pelas fermentações morais que determinaram as chamadas "questões militares". (Vianna, 2006: XXV).

$\mathrm{Na}$ análise de Francisco Iglésias, o aspecto essencial da obra é o fato de que o princípio que irá defender, de forma arguta, coloca-o em acordo com os interesses da coroa. Fica mais evidente o argumento do historiador mineiro se nos detivermos na passagem de Oliveira Vianna que explica sua compreensão das medidas adotadas por D. Pedro II em relação ao processo que acabou culminando com o fim da escravidão no Brasil. Segundo o jurista fluminense:

O pensamento tão claramente manifesto de D. Pedro II sobre a Abolição, o seu famoso "pacto" com Dantas, o seu claro aplauso às atitudes parlamentares deste, faziam-no aos olhos do terrível tribuno conservador, um verdadeiro conspirador contra o regime - e daí o sensacional apodo que lhe atirou, com emoção de toda Câmara, de "príncipe conspirador." O Imperador, aliás, neste assunto, não tinha opiniões radicais; era partidário de uma política moderada; sentia-se que o seu pensamento era atingir a extinção da escravidão através da fórmula da emancipação gradual. Quando ele impeliu Dantas para a agitação do problema, índice segura desta sua feição moderada, foi a sua frase: - "Pois bem, senhor Dantas, mas quando o senhor quiser correr, eu o puxo pela aba da casaca." (Vianna, 2006).

As preocupações de Vianna são nitidamente contrárias a qualquer tipo de "agitação", pois isso feria os interesses dos setores proprietários, que estavam acostumados desde que fossem condicionadas as suas reivindicações. Sendo assim, 
explica-se a discussão a respeito da "indenização dos proprietários de escravos", ainda citando Oliveira Vianna:

Feita a Abolição, já sob a regência de D. Isabel, D. Pedro, ao chegar da Europa, teve sua frase expressiva: - "Se estivesse aqui, talvez não fizesse o que se fez" o que parece mostrar que o radicalismo da Lei de 13 de Maio teria sido muito atenuado, se ele estivesse presidido à última fase da elaboração legislativa da sua grande idéia. Provavelmente, ter-se-ia dado aos proprietários uma justa indenização. (Vianna, 2002).

Um exemplo expressivo desse posicionamento, que em grande medida ilustra o tipo de sociedade que defende sua manifestação contrária a defesa da indenização almejada pelos proprietários de escravos. Nessa perspectiva, Francisco Iglésias identifica os traços típicos do conservadorismo na obra de Oliveira Vianna, entendendo que os mais marcantes seriam a defesa do estado autoritário e o descaso pelo povo, cuja condição subalterna é, em alguns momentos, considerada natural. Ao perceber esse aspecto peculiar no texto de Oliveira Vianna, o historiador mineiro amplia as análises que se debruçam sobre sua obra e mostra os limites de seu tradicionalismo e de sua concepção obtusa do Estado e sociedade. 


\section{Considerações Finais}

O valor de um complexo filosófico reside no grau de articulação que consegue estabelecer entre as respostas que fornece às questões colocadas pela sua inserção histórica num tempo e numa sociedade determinados e a ampliação da problemática e das soluções que introduz no interior do conjunto cultural de que, de uma forma ou de outra, é herdeiro. Precisamente, a avaliação de um tal complexo exige o trânsito entre o esclarecimento que traz. às "questões do dia" e a contribuição com que acresce o conjunto ideológico-cultural mais abrangente em que se situa. (Georg Lukács)

Ao longo dessa pesquisa pretendemos resgatar a produção intelectual de José Honório Rodrigues, diferentemente da maioria dos trabalhos que versam sobre o autor, nosso intuito foi identificá-lo como um expoente do pensamento social brasileiro, pois seu legado nos fornece elementos para a interpretação de nossa sociedade a partir do ponto de vista de um processo constante de práticas conciliatórias que não permitiram que houvesse uma maior integração do povo a sociedade de classes.

$\mathrm{Na}$ pretensão de compreender como o movimento político social do Brasil ao longo do decênio de 1950 foi decisivo para que houvesse uma inflexão na produção de José Honório, pois até então tínhamos um historiador preocupado em contribuir para que a historiografia ganhasse o seu espaço definitivo e passasse a ser elemento de preocupação constante entre os iniciados na disciplina, com sua passagem pela Escola Superior de Guerra, a produção honoriana voltava-se em entender o "presente" e procurar formas de participação ativa no dia-a-dia do país.

Autor de quase trinta livros, além de inúmeros ensaios e artigos sobre a sociedade brasileira, um intelectual reformista que propunha a necessária reestruturação da sociedade brasileira para que as mais elementares e legitimas necessidades do povo fossem, enfim, atendidas. Para contemplar esse intento na análise da sociedade a proposta do intelectual carioca foi perseguir ao longo da História do Brasil os momentos em que existiram projetos e ações que procuravam a cooptação dos grupos dominados, 
dar luz as tentativas de aliciar as classes dominadas com pequenas vantagens. Quando houve a recusa e, por parte dos setores subalternos, algum tipo de resistência ganha destaque a prática da violência pela elite dominante.

Instalava-se assim a história cruenta, esse peculiar da história do Brasil que gerou violência ostensiva contra a população em seus momentos de ação e tentativa de enfrentamentos aos históricos maus tratos sofridos. Honório vislumbra nesse processo a forma como a intelectualidade brasileira sempre "pintou com cores fortes" a cordialidade e passividade do povo e deixou a segundo plano essa situação de opressão e de ações cruentas.

Dificilmente algum intelectual vinculado ao grupo social que representava o interesse da elite dirigente do país pudesse de forma tão aguda discorrer a respeito das mazelas do povo. José Honório Rodrigues com sua capacidade de pensador atento as questões sócias de forma instigante sempre apontou o conjunto de contradições. Entre essas poderíamos destacar a repressão que foi colocada em prática durante o Período Regencial e mesmo no desenvolvimento da Abolição, dois momentos em que a intolerância da elite brasileira e o posicionamento "arribado"168 da intelectualidade não denunciou de forma aguda o povo ser constantemente "capado e sangrado".

O que poderíamos apontar, portanto em Honório que seria sua particularidade, o núcleo de suas argumentações que o colocam num plano diferenciado entre aqueles que procuraram "Pensar o Brasil"? A resposta aqui seria o Nacionalismo. Esse foi o mote de ação e reflexão de José Honório. Sua base epistemológica que o acompanhou até sua morte sua meta como intelectual que, de forma ostensiva, procurava apontar os rumos e as contradições de sua sociedade que não vislumbrava criar condições básicas para a sobrevivência do povo brasileiro.

Nessa pesquisa tivemos a oportunidade de compreender como se constitui uma obra que tem como meta a interpretação da sociedade, partindo de um intelectual que apresentava como fim superar os tramites de crítico da História e caminhar para a compreensão das contradições mais prementes da sociedade brasileira.

\footnotetext{
${ }^{168}$ A respeito do termo o professor Francisco de Oliveira, ao identificar a mudança na atuação dos intelectuais a medida que aqueles se transformavam em "gestores do poder", afirma que: "O fato é que os intelectuais estão abandonando suas pesquisas, suas salas de aula, seus laboratórios, para transformaremse em gestores do poder: migrando para o controle da burocracia da pesquisa, para postos governamentais nos níveis federal e estadual. Mais: a arma da crítica foi sendo gradualmente posta de lado, substituída por uma subliteratura apologética, justificada pelo papel do intelectual na construção da democracia e pelos riscos a que essa "novidade" está sujeita." (Oliveira, 1985: 21).
} 
Cabe destacar que já na produção do crítico da "Historiografia conservadora" existia a conceituação da interpretação tradicionalista de história, localizando-a no contexto brasileiro, ou melhor, na definição do processo histórico do Brasil recém independente. Embora se possa discutir a simplificação da discussão presa a período da monarquia - principalmente na crítica a Varnhagen fruto do Romantismo associado à interpretação "Bragantina" da História do Brasil.

Seu nacionalismo-liberal permitiu identificar Tavares Bastos como o maior pensador político do século XIX, pois era adepto ao pensamento liberal do político alagoano, principalmente, quanto à defesa de princípios liberais, próximos a Tocqueville, no Brasil. Com isso acreditamos que o perfil de José Honório Rodrigues permite vinculá-lo ao seleto grupo de interpretes da sociedade,

Dessa forma acreditamos que o intelectual por nos recuperado para a realização dessa pesquisa procura "as respostas que fornece às questões colocadas pela sua inserção histórica num tempo e numa sociedade determinado", tal como sentenciou Lukacs, não se omitindo das problematizações típicas da sociedade. Além disso, José Honório postava sua análise histórica em questões que despontavam na sociedade, atento sempre às "questões do dia”. Se a aproximação com Croce pode ser um limite no sentido de pouco aferir de crítica sua obra, esse intelectual, que sempre viveu na trincheira, é meritório de destaque e ocupar um espaço entre o seleto grupo de "Intérpretes do Brasil". 
Fontes:

RODRIGUES, José Honório. A luta metodológica e ideologia. João Pessoa/PB: Editora Universitária UFPB, 1981.

RODRIGUES, José Honório. A pesquisa histórica no Brasil, São Paulo: Companhia Editora Nacional, 1982, 4ª edição.

RODRIGUES, José Honório. Apresentação as obras de Capistrano de Abreu, Rio de Janeiro, Civilização Brasileira, 1976a.

RODRIGUES, José Honório. Aspiracões Nacionais: interpretacão histórico-politica. Rio de Janeiro, Civilização Brasileira, 1970, $4^{\mathrm{a}}$ edição.

RODRIGUES, José Honório. Brasil e África: outros horizontes. Rio de Janeiro, Nova Fronteira, 1980.

RODRIGUES, José Honório. Conciliação e Reforma no Brasil: um desafio históricopolítico. Rio de Janeiro, Civilização Brasileira, 1965.

RODRIGUES, José Honório. Discurso de posse na Academia Brasileira de Letras (5 de dezembro de 1969, Rio de Janeiro: ABL, (mimeografo), 1969, pp. 178-212.

RODRIGUES, José Honório. Ensaios livres, São Paulo: Imaginário, 1991. RODRIGUES, José Honório. Filosofia e história, Rio de Janeiro: Nova Fronteira, 1981.

RODRIGUES, José Honório. História combatente. Rio de Janeiro: Nova Fronteira, 1982.

RODRIGUES, José Honório. História corpo do tempo, São Paulo: Perspectiva, 1976.

RODRIGUES, José Honório. História diplomática do Brasil. Rio de Janeiro: Civilização Brasileira, 1995.

RODRIGUES, José Honório. História da História do Brasil. (Historiografia colonial volume 1). São Paulo, Companhia Editora Nacional, 1988.

RODRIGUES, José Honório. História da História do Brasil. (Historiografia conservadora - volume 1/tomo 1). São Paulo, Companhia Editora Nacional, 1988a.

RODRIGUES, José Honório. História da História do Brasil. (A metafísica do latifúndio o ultra-reacionário Oliveira Vianna - volume 1/tomo 2). São Paulo, Companhia Editora Nacional, 1988b.

RODRIGUES, José Honório. História Viva, São Paulo: Global, 1985.

RODRIGUES, José Honório. Interesse Nacional e política externa, Rio de Janeiro, Civilização Brasileira, 1966. 
RODRIGUES, José Honório. Independência: revolucão e contra-revolucãa. Rio de Janeiro, Editora Francisco Alves, 1975.

RODRIGUES, José Honório. "Introdução” In: Bastos, Tavares. Males do presente e as esperanca do futuro. São Paulo: Companhia editora nacional, 1976 b.

RODRIGUES, José Honório. Notícia de Varia História. Rio de Janeiro, Livraria São José, 1951.

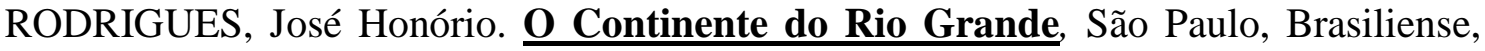
1986a.

RODRIGUES, José Honório. Tempo e Sociedade. Petrópolis, Vozes, 1986.

RODRIGUES, José Honório. Teoria da História do Brasil: introducão metodológica, São Paulo: Companhia editora nacional, 1978.

RODRIGUES, José Honório. Vida e História. São Paulo, Perspectiva, $1986 b$. 


\section{Bibliografia:}

ABREU, Capistrano de. O descobrimento do Brasil. São Paulo, Martins Fontes, 1999. ABREU, Capistrano de Capítulos de História Colonial. Rio de Janeiro, Civilização Brasileira, 1976, 6 a edição.

ABREU, Capistrano de. Ensaios e Estudos, Rio de Janeiro: Civilização Brasileira, 1976b.

ALONSO, Ângela. Ideias em movimento: geração de 1870 na crise do Brasil Império, Rio de Janeiro: Paz e Terra, 2002.

AMED, Fernando. As cartas de Capistrano de Abreu. São Paulo: Alameda, 2006.

ARANTES, Otília B. Fiori e ARANTES, Paulo Eduardo. Sentido da formacão: três estudos sobre Antonio Candido, Gilda de Mello e Souza e Lúcio Costa. São Paulo: Paz e Terra, 1997.

ARANTES, Paulo Eduardo. "Providências de um crítico literário na periferia do capitalismo". In: ARANTES, Otília B. Fiori e ARANTES, Paulo Eduardo. Sentido da formacão: três estudos sobre Antonio Candido, Gilda de Mello e Souza e Lúcio Costa. São Paulo: Paz e Terra, 1997.

ASSIS, Machado. Crônicas escolhidas, São Paulo: Ática, 1993.

BANDEIRA, Moniz. Relacões Brasil-EUA no contexto da globalizacão, São Paulo: SENAC, 1998.

BASTOS, Aurélio Cândido Tavares. A Província. São Paulo, Companhia Editora Nacional (Coleção Brasiliana), 1975.

BASTOS, Tavares. Males do presente e as esperança do futuro. São Paulo: Companhia editora nacional, 1976.

BASTOS, Elide Rugai e MORAES, João Quartim de. In: $\underline{\mathbf{O} \text { pensamento de Oliveira }}$ Vianna. (orgs.). Campinas/São Paulo: UNICAMP, 1993.

BENEVIDES, Maria Victoria Mesquita. $\underline{\mathbf{O} \text { governo Kubitschek: desenvolvimento e }}$ estabilidade política, RJ, Paz e Terra, 1979.

BEHRING, Elaine Rosseti. Brasil em contra-reforma: desestruturacão do Estado e perda de direitos. São Paulo: Cortez, 2003.

BIELSCHOWSKY, Ricardo. Pensamento econômico brasileiro: $\mathbf{O}$ ciclo ideológico do desenvolvimento. Rio de Janeiro: Contraponto, 2000.

BLACKBURN, Robin. A construcão do escravismo no Novo Mundo. Rio de Janeiro, Record, 2003. 
BLACKBURN, Robin. A queda do escravismo colonial (1776-1848), Rio de Janeiro, Record, 2002.

BONIFÁCIO, José. “Apontamentos". Caldeira, Jorge (org). José Bonifácio de Andrada e Silva. São Paulo, Editora 34, 2002.

BOSI, Alfredo. História concisa da literatura brasileira. São Paulo: Cultrix, 1994, $33^{\mathrm{a}}$ edição.

BOTELHO, André. Aprendizado do Brasil: a nação em busca dos seus portadores sociais. Campinas/São Paulo: Ed. UNICAMP, 2002.

BOTELHO, André. "Uma sociedade em movimento e sua intelligentsia: apresentação". In: Botelho, A., Boas, Glaucia V. e Bastos, Elide R. In: $\underline{\text { O moderno em questão: a }}$ década de 1950 no Brasil, Rio de Janeiro: Topbooks, 2008.

BOTELHO, André, BOAS, Glaucia V. e BASTOS, Elide R. In: $\underline{\mathbf{O} \text { moderno em }}$ questão: a década de 1950 no Brasil. Rio de Janeiro: Topbooks, 2008.

BOTELHO, André e SCHWARCZ, L. M (org.). Um enigma chamado Brasil: 29 intérpretes do Brasil, São Paulo: Companhia das Letras, 2009

BOTELHO, André. $\underline{O}$ Brasil e os dias: estado-nação, modernismo e rotina intelectual. Bauru/SP: EDUSC, 2005.

BOTTMANN, Denise Guimarães. Padrões Explicativos na Historiografia Brasileira. 1985. Dissertação (Mestrado em História) - Universidade Estadual de Campinas. (mimeografo).

BRANDÃO, Gildo Marçal. Linhagens do pensamento político brasileiro, São Paulo: Hucitec, 2007.

BRESSER PEREIRA, Luiz Carlos. Crise econômica e reforma do Estado no Brasil: para uma nova interpretacão da América Latina, São Paulo: Editora 34, 1996.

BRESSER PEREIRA, Luiz Carlos. "Um novo estudo para a América Latina”. Novos estudos CEBRAP, nº50, São Paulo, 1998.

BUENO, Clodoaldo e CERVO, Amado Luiz. História da política exterior do Brasil. São Paulo: Ática, 1995

CALDEIRA, Jorge (org). José Bonifácio de Andrada e Silva. São Paulo, Editora 34, 2002.

CAMARGO, Aspásia. Apresentacãão: Diplomacia em alto-mar. Rio de Janeiro: FGV, 2003.

CANDIDO, Antonio. Formacão da Literatura brasileira, Rio de Janeiro, Ouro sobre azul, 2007, $11^{\text {a }}$ edição. 
CANDIDO, Antonio. "Prefácio". In: Lafeta João Luiz. 1930: A crítica e o modernismo. São Paulo: Duas Cidades/34, 2000.

CANDIDO, Antonio. Vários escritos, Rio de Janeiro, Ouro sobre azul, 2004.

CANÊDO, Letícia Bicalho. "Democracia: aprendendo a votar". In: PINSKY, Jayme.

História da cidadania, São Paulo, Contexto, 2001.

CARDOSO, Fernando Henrique. Capitalismo e escravidão no Brasil Meridional, Rio de Janeiro: Civilização Brasileira, 2003.

CARVALHO, José Murilo. A construcão da ordem. Rio de Janeiro, Civilização Brasileira, 2006, $2^{a}$ edição.

CARVALHO, José Murilo (org.). Bernardo Pereira de Vasconcelos (colecão Formadores do Brasil. São Paulo: Editora 34, 1999.

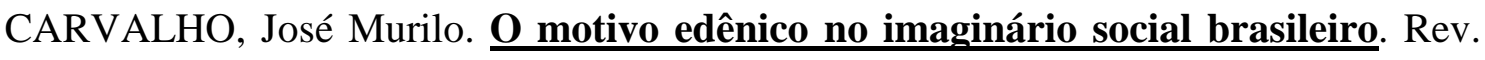
bras. Ci. Soc., Out 1998, vol.13, no.38.

CARVALHO, José Murilo. Os Bestializados. São Paulo, Cia. das Letras, 1987.

CARVALHO, José Murilo. Pontos e Bordados. Belo Horizonte, Editora UFMG, 1998.

CARVALHO, José Murilo. "O radicalismo político no Segundo Reinado". In: Botelho,

A. e Schwarcz, L. M. Um enigma chamado Brasil: 29 interpretes do Brasil, São

Paulo: Companhia das Letras, 2009, pp.32-44.

CARVALHO, Maria Alice Resende de. $\underline{\mathbf{O} \text { quinto século: André Reboucas e a }}$ construcão do Brasil, Rio de Janeiro, REVAN, 1998.

CHASIN, José. A miséria brasileira. Santo André/SP, AD. Hominen, 2000.

COMBLIN, Joseph. A ideologia de seguranca nacional: o poder militar na América

Latina. Rio de Janeiro: Civilização Brasileira, 1980, $3^{\text {a }}$ edição.

COMTE, Auguste. Comte (colecão grandes cientistas sociais) / Evaristo de Moraes Filho (Org.). São Paulo: Ática, 1978.

COSTA SILVA, Albero. “Conciliação e reforma no Brasill”. In: Mota, Lourenço Dantas (org.). Introducão ao Brasil: um banquete nos trópicos. São Paulo: SENAC, 1999.

COSTA, Emília Viotti da. Da Monarquia a República: momentos decisivos. São Paulo, Editora UNESP, $7^{a}$ edição. 1999.

COSTA, Marcos. Para uma nova história: textos de Sérgio Buarque de Hollanda. São Paulo: Fundação Perseu Abramo, 2004.

COSTA, Wilma Peres. “A independência na historiografia brasileira”. In: JANCSO, István (org). Independência: História e Historiografia, São Paulo: Hucitec / FAPESP, 2005 . 
COVRE, Maria de Lourdes Manzini. A fala dos homens: análise do pensamento tecnocrático. São Paulo: Brasiliense, 1983.

COUTINHO, Carlos Nelson. Cultura e sociedade no Brasil, Rio de Janeiro: DP\&A, 2000.

COUTINHO, Carlos Nelson. Gramsci: um estudo sobre seu pensamento político.

Rio de Janeiro: Civilização Brasileira, 2003.

COUTINHO, Carlos Nelson, Intervenções: o marxismo na batalha das ideias. São Paulo: Cortez, 2006.

CUNHA, Vasco Leitão da. Diplomacia em alto mar (depoimento CPDOC), Rio de Janeiro: Fundação Alexandre Gusmão/Editora FGV, 2003.

DOLHNIKOFF, Miriam. Projeto para o Brasil. São Paulo, Companhia das Letras, 1998.

ECO, Umberto. Como se faz uma tese. São Paulo, Perspectiva, 2003,18 edição.

DANTAS, San Tiago. "Política Externa Independente". In: Munteal, Oswaldo, Ventapane, Jacqueline e Freixo, Adriano de. $\underline{\text { O Brasil de João Goulart: um projeto de }}$ nacão. Rio de Janeiro: PUC-RIO/Contraponto, 2006.

DEBRUN, Michel. A conciliacão e outras estratégias, São Paulo: Brasiliense, 1983.

DEL VECCHIO, "Um paradoxo do regime militar brasileiro: terror de Estado e processo de distensão política no governo Médici” In: Martins Filho, João Roberto, $\underline{\mathbf{O}}$ Golpe de 1964 e o Regime Militar: Novas perspectivas, São Carlos/SP: EDUFSCAR, 2006. pp. 129-142.

DREYFUSS, René Armand. 1964: A conquista do Estado - acão política, poder e golpe de classe. Petrópolis/RJ: Vozes, 1986.

FAORO, Raymundo. Existe pensamento político brasileiro? São Paulo, Brasiliense, 1994.

FAORO, Raymundo. Os donos do poder: formacão do patronato político brasileiro, Rio de Janeiro: Globo, 1958.

FAUSTO, Boris. História do Brasil. São Paulo, Editora da USP, 1994.

FAUSTO, Boris. A revolucão de 1930: historiografia e história. São Paulo, Brasiliense, 1970.

FEIJÓ, Diogo Antônio. Diogo Antônio Feijó / organização, apresentação e notas de Jorge Caldeira, São Paulo: Editora 34, 1999.

FERNANDES, Florestan. A sociologia no Brasil: contribuicão para o estudo de sua formacão e desenvolvimento. Petrópolis, Vozes, 1971. 
FERNANDES, Florestan. A revolucão burguesa no Brasil: ensaio de interpretacão

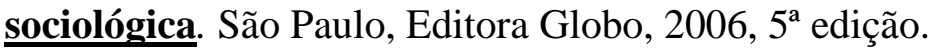

FERNANDES, Florestan. Circuito Fechado, SP, Hucitec, 1979.

FERREIRA, Gabriela Nunes. Centralizacão e descentralizacão no Império: o debate entre Tavares Bastos e visconde de Uruguai.São Paulo: Editora 34 Letras, 1999.

FICO, Carlos. "O Brasil no contexto da Guerra Fria: democracia, subdesenvolvimento e ideologia do planejamento (1946-1964)". In: Mota, C. G. (org.). Viagem incompleta: a experiência brasileira, São Paulo: SENAC, 2000, pp. 163-182.

FONSECA, Pedro Cezar Dutra da. Vargas: O capitalismo em construcão (19061954), São Paulo: Brasiliense, 1989

FRANCO, Maria Sylvia de Carvalho. Homens livres na ordem escravocrata, São Paulo: UNESP, 1997, $4^{\text {a }}$ edição.

FRANCO, Maria Sylvia de Carvalho. "As ideias estão no lugar”. In: Cadernos de debate, São Paulo: Brasiliense, 1976, pp. 61-63.

FREDERICO, Celso. Sociologia da Cultura: Lucien Goldmann e os debates do século XX, São Paulo: Cortez, 2006

FREUND, Julien. Sociologia de Max Weber. Rio de Janeiro, Forense Universitária, $2006,5^{\text {a }}$ edição.

FREYRE, Gilberto. Casa Grande e Senzala: formacão da família brasileira sob o regime da economia patriarcal, São Paulo: Global, 2005, 50ª edição.

FREYRE, Gilberto. Sobrados e mucambos: decadência do patriarcado rural e desenvolvimento do urbano. São Paulo: Global, 2004, 15 edição;

GIDDENS, Anthony. As consequências da modernidade, São Paulo, UNESP, 1991.

GIDDENS, Anthony. Política, sociologia e teoria social, São Paulo, UNESP, 1998.

GIDDENS, Anthony. Modernização reflexiva: política, tradicão e estética na ordem social moderna. São Paulo: UNESP, 1997.

GOLDMANN, Lucien. Ciências Humanas e filosofia. Rio de Janeiro, Bertrand Brasil, 1993.

GOLDMANN, Lucien. Criação cultural na sociedade moderna: por uma sociologia da totalidade. São Paulo: Difusão Européia do Livro, 1972.

GOLDMANN, Lucien. Crítica e dogmatismo na cultura moderna, Rio de Janeiro: Paz e Terra, 1973.

GOLDMANN, Lucien. Epistemologia e filosofia política. Lisboa, Editorial Presença, 1978. 
GOMES, Ângelo de Castro. "Oliveira Vianna: um statemaker na alameda São Boaventura". In: Botelho, A. e Schwarcz, L. M. Um enigma chamado Brasil: 29 intérpretes do Brasil, São Paulo: Companhia das Letras, 2009, pp. 144-159.

GRAMSCI, Antônio. Cadernos do cárcere. Volume 1: Introdução ao estudo da filosofia - A filosofia de Benedeto Croce. Rio de Janeiro: Civilização Brasileira, 2004.

GRAMSCI, Antônio. Cadernos do cárcere. Volume 2: Os intelectuais. O principio educativo. Jornalismo. Rio de Janeiro: Civilização Brasileira, 2000.

GUIMARÃES, Renato. "Cabanagem: a Revolução no Brasil”, Temas de Ciências Humanas, São Paulo: Livraria Editora Ciências Humanas, 1978, pp. 93-130.

HOBSBAWM, Eric J. A era dos extremos. São Paulo: Companhia das Letras, 1995.

HOBSBAWM, Eric J. Nacões e nacionalismo desde 1789: programa, mito e realidade. São Paulo: Paz e Terra, 1990.

HOBSBAWM, Eric J. e RANGER, Terence (org.). A invencão das tradicões. São Paulo: Paz e Terra, 2002.

HOLLANDA, Sérgio Buarque. "Apologia da história”. In: Costa, Marcos. Para uma nova história: textos de Sérgio Buarque de Hollanda. São Paulo: Fundação Perseu Abramo, 2004, pp. 108-111.

HOLLANDA, Sérgio Buarque. Raízes do Brasil. São Paulo: Companhia das Letras, 1995, 26 a edição.

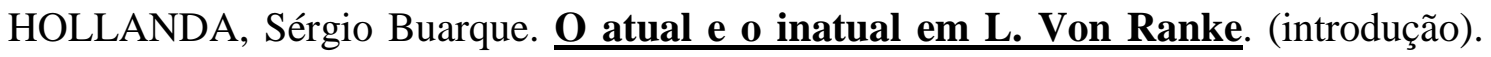

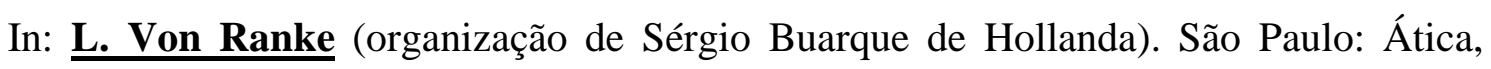
1979.

IANNI, Octávio. Pensamento Social no Brasil. Bauru, Edusc, 2005.

IANNI, Octávio. Estado e planejamento econômico no Brasil, Rio de Janeiro: Civilização Brasileira, 1986, $4^{\mathrm{a}}$ edição.

IANNI, Octávio e CARDOSO, Fernando Henrique. Homem e Sociedade. São Paulo, Companhia Editora Nacional, 1984, 14ª edição.

IANNI, Octávio. Ideia de Brasil moderno, São Paulo: Brasiliense, 1996, $3^{\text {a }}$ edição.

IGLÉSIAS, Francisco. História e Ideologia, São Paulo: Perspectiva, 1971.

IGLÉSIAS, Francisco. História e Literatura, São Paulo: Perspectiva, 2009.

JAGUARIBE, Hélio. ISEB - Um breve depoimento e uma reapreciação crítica. In:

“Cadernos de Opinião”, São Paulo: Brasiliense, 1977, pp. 94-110.

JANCSO, István (org). Independência: História e Historiografia, São Paulo: Hucitec/Fapesp, 2005. 
JASMIN, Marcelo. Alexis de Tocqueville: a historiografia como ciência da política. Belo Horizonte/MG: Ed. UFMG; Rio de Janeiro: IUPERJ, 2005. $2^{\text {a }}$ edição.

KONDER, Leandro. A derrota da dialética, Rio de Janeiro: Campus, 1988.

LAFETA, João Luiz. 1930: A crítica e o modernismo. São Paulo: Duas Cidades/34, 2000.

LAHUERTA, Milton. "Marxismo e vida acadêmica: os pressupostos intelectuais da crítica uspiana ao nacional-desenvolvimentismo". In: Botelho, A., Boas, Glaucia V. e

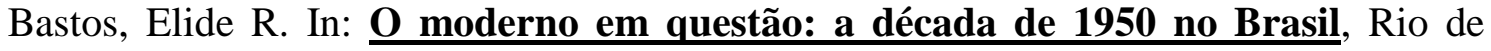
Janeiro: Topbooks, 2008.

LATTMAN-WELTMAN, Fernando. A política domestica: Afonso Arinos e o colapso da democracia em 1964. Rio de Janeiro: FGV, 2005.

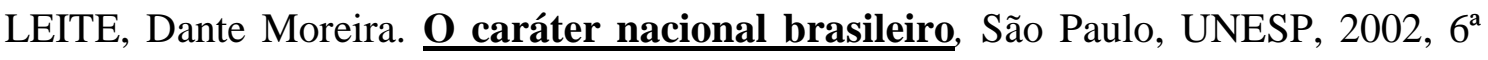
edição.

LIMA, Hermes. "Significação do Nacionalismo". In: $\underline{\mathbf{O} \text { pensamento nacionalista e os }}$ “Cadernos de nosso tempo". Seleção e introdução de Simon Schwartzman. Brasília: Editora Universidade de Brasília. 1981.

LIMA, Oliveira. O império brasileiro (1822-1889). Brasília: Editora Universidade de Brasília, 1986.

LOSURDO, Domenico. Contra-História do liberalismo, Aparecida, SP, Ideias \& Letras, 2006.

LOSURDO, Domenico. Democracia ou bonapartismo, Rio de Janeiro: Ed. UFRJ e São Paulo: UNESP, 2004.

LOSURDO, Domenico. Hegel, Marx e a tradição liberal: liberdade, igualdade e Estado, São Paulo: UNESP, 1998.

LOWY, Michel, As aventuras de Karl Marx contra o Barão de Münchhausen: marxismo e positivismo na sociologia do conhecimento, São Paulo: Cortez, 1998.

LOWY, Michel e NÄYR, Sami. Lucien Goldmann ou a dialética da totalidade. São Paulo, Boitempo, 2008.

LUKÁCS, Georg. Ensaios sobre a literatura, Rio de Janeiro: Civilização Brasileira, 1965.

LUKÁCS, Georg. História e consciência de classe. São Paulo: Martins Fontes, 2003.

MANENT, Pierre. História intelectual do liberalismo: dez licões, Rio de Janeiro: Imago, 1990.

MANNHEIM, Karl. Mannheim: sociologia. São Paulo: Ática, 1982. 
MANNHEIM, Karl. Ideologia e utopia. Rio de Janeiro: Jorge Zahar, 1967.

MANNHEIM, Karl. Sociologia da cultura, São Paulo: Perspectiva, 2008.

MARQUESE, Rafael de Bivar. Feitores do corpo, missionários da mente. Senhores, letrados e o controle dos escravos nas Américas, 1660-1860. São Paulo: Companhia das Letras, 2004.

MARTINS, Carlos Estevam. A evolucão da política externa brasileira (1964-1974). São Paulo, Novos Estudos CEBRAP, nº 12, 1975.

MARTINS FILHO, João Roberto, O Golpe de 1964 e o Regime Militar: novas perspectivas, São Carlos/SP: EDUFSCAR, 2006.

MARX, Karl. "Prefácio de 1859”. In: Para a crítica da economia política: Marx (Os pensadores), São Paulo: Nova Cultural, 1996 (Círculo do Livro).

MARX, Karl e ENGELS, Friedrich. A ideologia alemã: crítica da mais recente filosofia alemão em seus representantes Feuerbach, B. Bauer e Stirner e do socialismo alemão em seus diferentes profetas (1845-1846), São Paulo: Boitempo, 2007

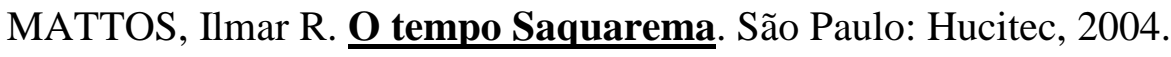

MAZZEO, Antonio Carlos. Estado e burguesia no Brasil: origens da autocracia burguesa. Belo Horizonte/MG: Oficina de Livros, 1989.

MELO, Wanderson Fabio. Institucionalizacão e modernização: o debate no Senado Federal entre Fernando Henrique Cardoso e Roberto de Oliveira Campos (19831989). Programa de Estudos Pós-Graduados, Doutorado em História, PUC de São Paulo, 2009.

MELLO, João Manuel C. de. e NOVAIS, Fernando. "Capitalismo tardio e sociabilidade moderna". In: Schwarcz, Lilia M.(org.). História da vida privada no Brasil: contrastes da intimidade contemporânea (Coordenacão geral da colecão Fernando Antonio Novais), São Paulo: Companhia das Letras, 1998, volume 4.

MELLO, José Octávio de Arruda. Cristianismo e diplomacia: no Brasil contemporâneo. Mossoró/Rio Grande do Norte: Fundação Ving-Um Rosado, 1998.

MENEZES, Adolpho Justo Bezerra de.Ásia, África e a política externa independente no Brasil, Rio de Janeiro: Jorge Zahar, 1961.

MENDES, Candido. Memento dos vivos: a esquerda católica, Rio de Janeiro: Templo Brasileiro, 1966.

MÉSZÁROS, István. O poder da ideologia, São Paulo: Ensaio, 1996. 
MÉSZÁROS, István. Estrutura social e formas de consciência: a determinacão social do método. São Paulo: Boitempo, 2009.

MICHELET, Jules. O Povo. São Paulo, Martins Fontes, 1988.

MILLS, Charles Wright. Sobre o artesanato intelectual. Tradução Antonio Ianni Segatto. Araraquara: Laboratório Editorial/FCL/UNESP; São Paulo: Cultura Acadêmica Editora, 2004.

MOORE JR, Barrington. As origens sociais da ditadura e da democracia: senhores e camponeses na construcão do mundo moderno, Lisboa: Cosmos, 1967.

MOTA, Carlos Guilherme. A ideia de Revolucão (1789-1801): estudo das formas de pensamento, SP, Cortez, 1989.

MOTA, Carlos Guilherme. A ideologia da cultura brasileira (1933-1974), SP, Ática, 1980.

MOTA, Carlos Guilherme. (org.) Viagem incompleta: a experiência brasileira, São Paulo: SENAC, 2000.

MOTA, Lourenço Dantas (org.) Introdução ao Brasil: um banquete nos trópicos. São Paulo: SENAC, 1999.

MUNANGA, Kabenguele. Rediscutindo a mesticagem no Brasil: identidade nacional versus identidade negra. Belo Horizonte/MG: Autêntica, 2006.

MUNTEAL, Oswaldo, VENTAPANE, Jacqueline e FREIXO, Adriano de. $\underline{\text { O Brasil de }}$ João Goulart: um projeto de nacão. Rio de Janeiro: PUC-RIO/Contraponto, 2006.

NABUCO, Joaquim. Um estadista do Império. Rio de Janeiro, Topbooks, 1997, $5^{\text {a }}$ edição.

NABUCO, Joaquim. O Abolicionismo. Rio de Janeiro, Topbooks, 1993.

NETTO, José Paulo. "Em busca da contemporaneidade perdida: a esquerda brasileira no pós-64”. In: Mota, C. G. (org.). Viagem incompleta: a experiência brasileira, São Paulo: SENAC, 2000, pp.219-245.

NETTO, José Paulo. Portugal: do fascismo à revolucão. Porto Alegre/RS: Mercado Aberto, 1986.

NOGUEIRA, Marco Aurélio. As desventuras do liberalismo: Joaquim Nabuco, a monarquia e a república, Rio de Janeiro, Paz e Terra, 1984.

NOVAIS, Fernando. Aproximações: ensaios de história e historiografia, São Paulo: Cosac Naify, 2005. 
NOVAIS, Fernando e ARRUDA, Maria Armindo do Nascimento. "Apresentação: revisitando intérpretes do Brasil". In: Dossiê Intérpretes do Brasil - anos 30, Revista $U S P, \mathrm{~N}^{\circ} 38$, jun/jul/ago de 1998.

ODALIA, Nilo. As formas do mesmo: ensaios sobre o pensamento historiográfico de Varnhagen e Oliveira Vianna, São Paulo: UNESP, 1997.

OLIVEIRA, Francisco de. "Aves de arribação: a migração dos intelectuais". In: Revista Lua Nova, volume 2 / Número 3 / outubro-dezembro de 1985. São Paulo: Brasiliense, 1985.

OLIVEIRA, Francisco de. Crítica à razão dualista: O ornitorrinco, São Paulo: Boitempo, 2003.

OLIVEIRA, Francisco de. A navegacão venturosa: ensaios sobre Celso Furtado, São Paulo, Boitempo, 2003a.

PEIXOTO, Antonio Carlos. "Exército e política no Brasil: uma crítica dos modelos de interpretação." In: Rouquié, A. (org.) Os partidos militares no Brasil, Rio de Janeiro: Record, 1980. pp. 27-42.

PINHEIRO Filho, F. A. "A invenção da ordem: intelectuais católicos no Brasil". Revista Tempo Social. vol.19/ nº 1, São Paulo: 06/2007.

PINSKY, Jayme e PINSKY, Carla Bassanezi. História da cidadania, São Paulo, Contexto, 2001.

PRADO Jr., Caio. Formacão do Brasil Contemporâneo, São Paulo: Brasiliense, 1996.

PRADO Jr., Caio. História econômica do Brasil, São Paulo: Brasiliense, 1980, 25 edição.

PRADO Jr., Caio. Evolucão política do Brasil, São Paulo, Brasiliense, 2006, 21 edição.

RAGO FILHO, Antonio. Os gestores do capital atrófico. Programa de Estudos PósGraduados, Doutorado em História, PUC de São Paulo, 1998.

REGO, Walquiria G. Domingues Leão. "Tavares Bastos e Oliveira Vianna: contraponto". In: BASTOS, Elide Rugai e MORAES, João Quartim de. In: $\underline{\mathbf{O}}$ pensamento de Oliveira Vianna. (orgs.). Campinas/São Paulo: UNICAMP, 1993.

REGO, Walquiria G. Domingues Leão. Tavares Bastos: um liberalismo descompassado. Revista da USP / nº 17 / março-abril-maio de 1983.

REGO, Walquiria G. Domingues Leão 
RIBEIRO, Darcy. O povo brasileiro: o sentido da formacão do Brasil. São Paulo, Companhia das Letras, 1996.

RICUPERO, Bernardo. Sete liç̃es sobre as interpretacões do Brasil, São Paulo, Alameda, 2007.

RODRIGUES, Leda Boechat e MELLO, José Octávio de Arruda. Um historiador na trincheira. Rio de Janeiro, Civilização Brasileira, 1994.

ROUQUIÉ, A. (org.) Os partidos militares no Brasil, Rio de Janeiro: Record, 1980.

ROUX, Alain. Guerras do ópio e a impotência do Império, In: Le Monde

Diplomatique, Edição brasileira, ano 5, nº 57, outubro/2008. (versão eletrônica).

SANTOS, Wanderley Guilherme dos Santos. Ordem burguesa e liberalismo político. São Paulo, Duas Cidades, 1978.

SANTOS, Wanderley Guilherme dos Santos. Paradoxos do liberalismo: teoria e história, São Paulo: Vértice, 1988.

SCHUMPETER, Joseph A. Capitalismo, socialismo e democracia. Rio de Janeiro: Jorge Zahar, 1984.

SCHWARCZ, Lilia M.(org.). História da vida privada no Brasil: contrastes da intimidade contemporânea (Coordenação geral da coleção Fernando Antonio Novais), São Paulo: Companhia das Letras, 1998, volume 4.

SCHWARTZMAN, Simon. (org.) 0 pensamento nacionalista e os "Cadernos de nosso tempo". Brasília: Editora Universidade de Brasília. 1981.

SCHWARZ, Roberto. Ao vencedor as batatas: forma literária e processo social nos inícios do romance brasileiro. São Paulo: Duas Cidades/34, 2000.

SCHWARZ, Roberto. Que horas são? (ensaios). São Paulo: Companhia das Letras, 1993.

SERRANO, Carlos e WALDMAN, Maurício. Memória D’África. São Paulo: Cortez, 2007.

SILVA, Luiz Fernando da. Pensamento social brasileiro: marxismo acadêmico entre 1960 e 1980. São Paulo: Corações e Mentes, 2003.

SKIDMORE, Thomas. Brasil: de Getúlio a Castelo. São Paulo: Paz e Terra, 2000.

SKINNER, Quentin. As fundacões do pensamento político moderno. São Paulo: Companhia das Letras, 2000.

SMALLMAN, Shawn C. "A profissionalização da violência extralegal das Forças Armadas no Brasil (1945-1964)". In: CASTRO, Celso e IZECKSOH, Vitor (org.) Nova história militar brasileira. Rio de Janeiro: FGV, 2004. 
SOARES, Gláucio Ary Dillon. A democracia interrompida. Rio de Janeiro: FGV, 2001.

SODRÉ, Nelson W. "Raízes históricas do nacionalismo brasileiro". In: Munteal, Oswaldo, Ventapane, Jacqueline e Freixo, Adriano de. O Brasil de João Goulart: um projeto de nação. Rio de Janeiro: PUC-RIO/Contraponto, 2006.

SOUZA, Jessé. A modernização seletiva: uma reinterpretacão do dilema brasileiro, Brasília: Editora da Universidade de Brasília, 2000.

TOCQUEVILLE, Alexis. A democracia na América. Belo Horizonte, Itatiaia, 1977, $2^{\mathrm{a}}$ edição.

TOLEDO, Caio Navarro. ISEB: fábrica de ideologias, São Paulo, Ática, 1977.

TOLEDO, Caio Navarro (org.). Intelectuais e política no Brasil, Rio de Janeiro, Revan, 2005.

TOLEDO, Caio Navarro. "Teoria e ideologia na perspectiva do ISEB”. In: Moraes, Reginaldo e Vera B. Ferrante (org.) Inteligência brasileira. São Paulo: Brasiliense, 1986.

VALE, Antônio Marques, O ISEB, os intelectuais e a diferenca: um diálogo teimoso na educacão, São Paulo, UNESP, 2006.

VARNHAGEN, Francisco Adolfo. História Geral do Brasil, Rio de Janeiro: Melhoramentos, 1962.

VASCONCELOS, Bernardo Pereira. "Discursos na Câmara dos deputados". In: Bernardo Pereira de Vasconcelos (Coleção Formadores do Brasil). José Murilo de Carvalho (org.). São Paulo: Editora 34, 1999.

VIANNA, Francisco José de Oliveira. O Ocaso do Império, (Introdução e apresentação José Murilo de Carvalho), Rio de Janeiro: ABL, 2006, $3^{\text {a }}$ edição.

VIANNA, Francisco José de Oliveira. Populacões meridionais do Brasil, Rio de Janeiro: José Olympio, 1952, $5^{\text {a }}$ edição, volume 1.

VIZENTINI, Paulo G. Fagundes. "Regime Militar brasileiro e sua política externa”. In: Martins Filho, João Roberto, $\underline{\text { O Golpe de } 1964 \text { e o Regime Militar: Novas }}$ perspectivas, São Carlos/SP: EDUFSCAR, 2006. pp. 143-159.

VIZENTINI, Paulo G. Fagundes. Relacões internacionais do Brasil: de Vargas a Lula. São Paulo: Fundação Perseu Abramo, 2008, $3^{\text {a }}$ edição.

VIZENTINI, Paulo G. Fagundes. Relacões internacionais e desenvolvimento: o nacionalismo e a política externa independente (1951-1964). Petrópolis/RJ: VOZES, 1995. 
VOVELLE, Michel. Jacobinos e Jacobinismo. Bauru/SP, EDUSC, 2000.

WEBER, Max. Ensaios de Sociologia. Rio de Janeiro: LTC, 1982, $5^{\text {a }}$ edição.

WEFFORT, Francisco Correia. Formacão do pensamento político brasileiro: ideias e personagens, São Paulo: Ática, 2006.

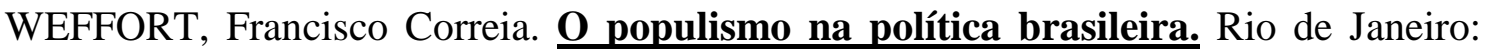
Paz e Terra, 1980.

WEHLING, Arno. Estado, História e Memória: Varnhagen e a construção da identidade nacional, Rio de Janeiro: Nova Fronteira, 1999.

WERNECK VIANNA, Luiz. Liberalismo e sindicato no Brasil, Rio de Janeiro: Paz e Terra, 1976.

WERNECK VIANNA, Luiz. A revolucão passiva: iberismo e americanismo no Brasil. Rio de Janeiro, Revan, 1997, 2ª edição.

WERNECK VIANNA, Luiz. "O pensar e o agir" Lua Nova (cedec). nº 54 / São Paulo: Cedec, 1998.

WERNET, Augustin. O período regencial, São Paulo: Global, 1982. 